\title{
The International Politics of Post-Conflict Reconstruction in Guatemala
}

Nicola Short

Thesis submitted for the degree of Doctor of Philosophy

London School of Economics and Political Science

University of London

December 2003 
UMI Number: U198862

All rights reserved

\section{INFORMATION TO ALL USERS}

The quality of this reproduction is dependent upon the quality of the copy submitted.

In the unlikely event that the author did not send a complete manuscript and there are missing pages, these will be noted. Also, if material had to be removed, a note will indicate the deletion.

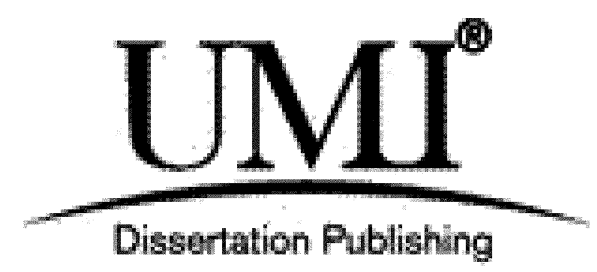

UMI U198862

Published by ProQuest LLC 2014. Copyright in the Dissertation held by the Author.

Microform Edition (c) ProQuest LLC.

All rights reserved. This work is protected against unauthorized copying under Title 17, United States Code.

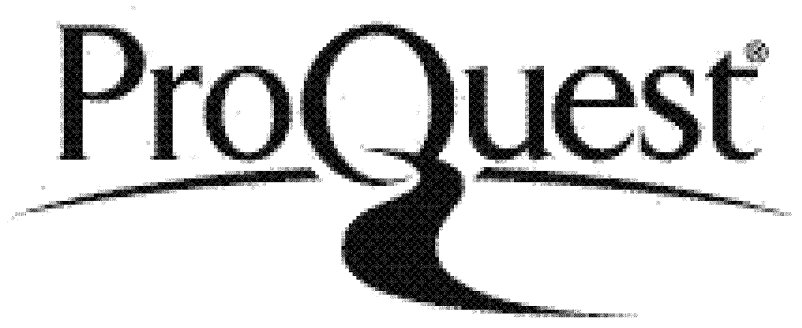

ProQuest LLC

789 East Eisenhower Parkway

P.O. Box 1346

Ann Arbor, MI 48106-1346 


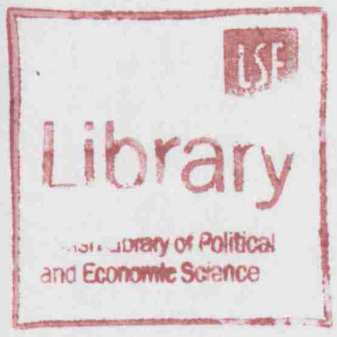

THESES

F

8327

985810 


\begin{abstract}
This thesis examines the international politics of post-conflict reconstruction in Guatemala. To do so, it articulates an analytical framework based on the political philosophy of Antonio Gramsci. The framework emphasises the nature of power, coercion and consent, and the problematic of political subjectivity, augmenting Gramsci's understanding of the latter with insights from Michel Foucault's notion of neoliberal governmentality. Based on this theoretical framework, the thesis examines the historical-material development of the Guatemalan ensemble of social relations into one of counterinsurgent disarticulation. It argues that counterinsurgency reflects the impulse to secure the 'remainder' of disarticulation - the exploited, marginalised, 'traditional' element of society constructed around semi-proletarian labour - a sector of society that is both (re)produced through disarticulation and denied by its 'modern' element. A crisis of counterinsurgent disarticulation leads to the Guatemalan peace process, which involves negotiations structured around certain understandings of democratic $p$ articipation that $p$ rotect elite $p$ rivilege, $p$ articularly electoral d emocracy and consultation with 'civil society'. The divisions within Guatemala's elites are not entirely resolved through the peace process: the accords reflect an unstable 'caesarist' resolution (a form of 'passive' h egemony) that relies on a coalition of modernising elites, the international community and the guerrilla. This coalition agrees a set of peace accords that would reconstruct the post-conflict Guatemalan state along neoliberal lines, at the level of both society and individual subjectivity. Although the agreements are not fully implemented, the pattern of implementation itself reflects particular neoliberal priorities, while the normative project of peace validates the ethico-political claims of neoliberalism and (re)defines progressive politics in Guatemala in terms of the implementation of the neoliberal accords. The thesis thus argues that peace processes may function as technologies for the (re)construction of neoliberalism.
\end{abstract}




\section{Table of Contents}

THE INTERNATIONAL POLITICS OF POST-CONFLICT RECONSTRUCTION IN

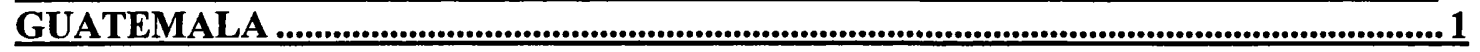

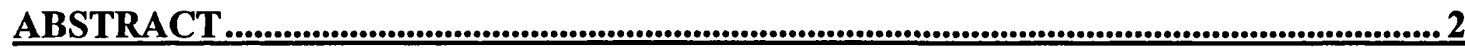

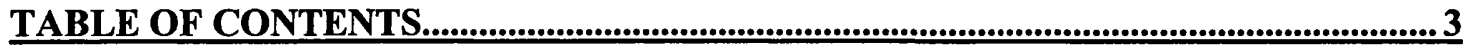

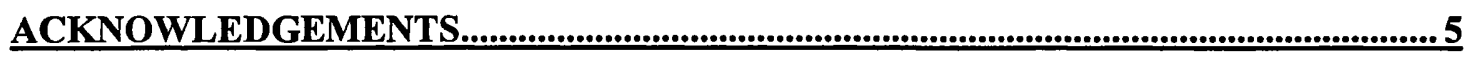

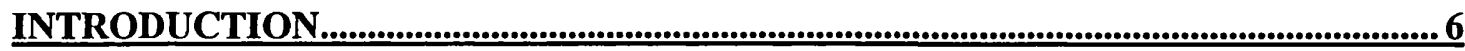

CRITICAL PERSPECTIVES ON THE 'SUCCESS' NARRATIVE .......................................................9

A GRAMSCIAN READING OF THE GUATEMALAN PEACE PROCESS ....................................... 11

PEACE PROCESSES AND THE (RE)CONSTRUCTION OF WORLD ORDER.......................................... 17

GRAMSCIAN POLITICS AND THE STUDY OF PEACE PROCESSES..................22

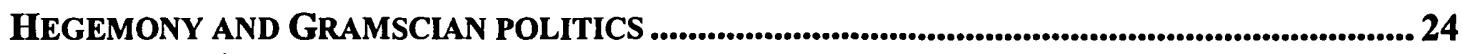

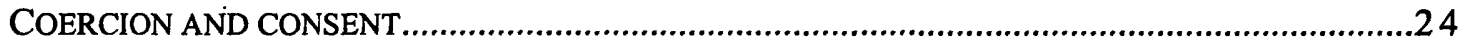

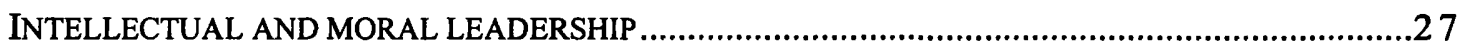

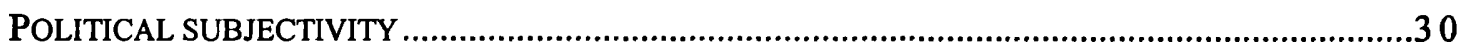

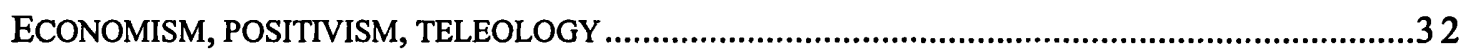

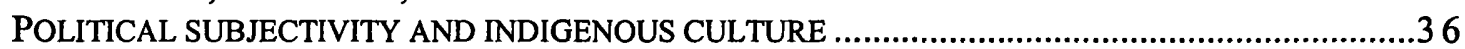

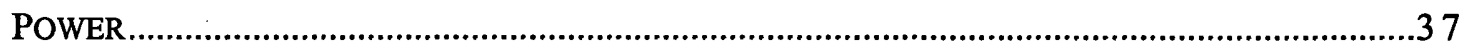

GRAMSCIAN POLITICS AND SOCIAL CHANGE ..........................................................4

HISTORICAL BLOCS, THE INTEGRAL STATE AND WORLD ORDERS ................................ 43

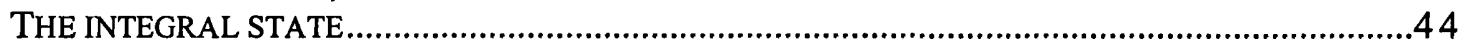

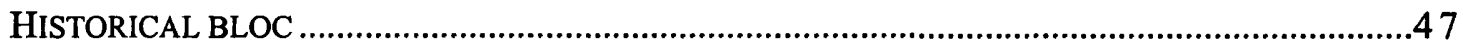

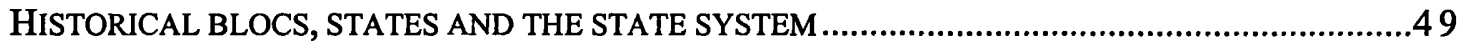

WORLD ORDER AND THE POST-WWII HISTORICAL BLOC: DEVELOPMENT AND

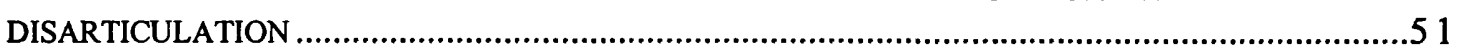

WORLD ORDER AND THE FINANCIAL CRISES OF THE 1970S: NEOLIBERALISM ........................5 6

PEACE PROCESSES AS TECHNOLOGIES OF NEOLIBERALISM ............................................6 1

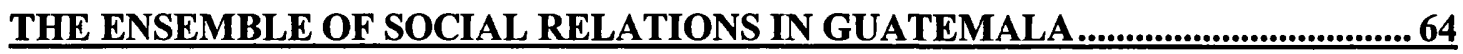

DISARTICULATION, COUNTERINSURGENCY AND THE ONTOLOGY OF CONFLICT .............. 66

DISARTICULATION AND COUNTERINSURGENCY ......................................................69

DISARTICULATION IN GUATEMALA: RACE, FORCE, AND ECONOMY ............................... 75

CHALLENGING DISARTICULATION: REFORMS AND REACTION ....................................8 87

THE POST-REFORM ENSEMBLE OF SOCIAL RELATIONS...................................................96

CONTRADICTIONS OF DISARTICULATION: REBELLION AND POPULAR ORGANISING ..............1 02

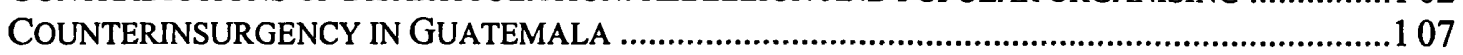

COUNTERINSURGENCY AS PRELUDE TO THE PEACE PROCESS ........................................... 111

THE STRUCTURE OF THE 'NATIONAL' ECONOMY ..........................................................1 12

THE NATIONAL ECONOMY AS THE FIRM .................................................................... 118

THE NEW TERRAIN OF CIVIL SOCIETY ................................................................. 121 
THE PEACE PROCESS

THE CRISIS OF THE COUNTERINSURGENT STATE ............................................................. 134

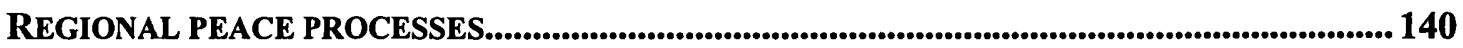

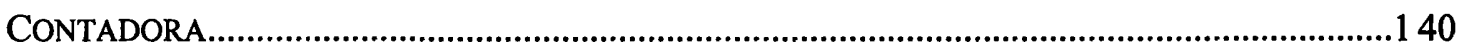

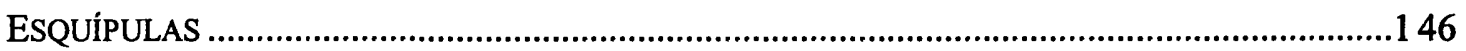

THE GUATEMALAN PEACE PROCESS ............................................................................ 150

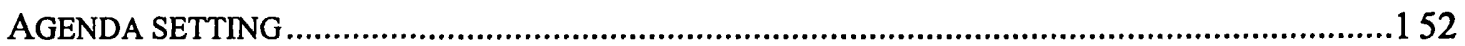

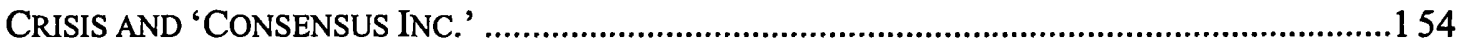

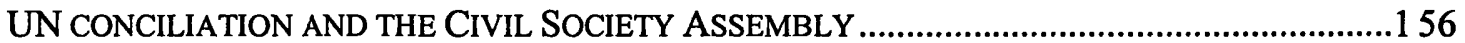

NEGOTIATING THE 'ESSENTIAL' ........................................................................................... 165

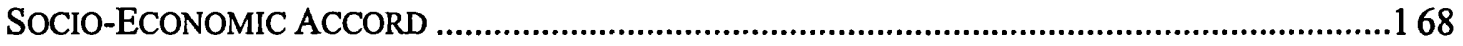

MILITARY REFORM AND THE REINTEGRATION OF THE URNG ..............................................1 171

ARTICULATING THE POST-CONFLICT STATE: THE TEXTS OF THE ACCORDS....................... 175

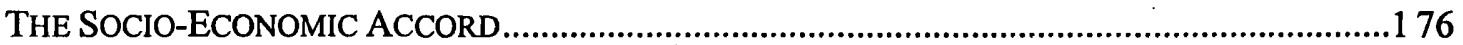

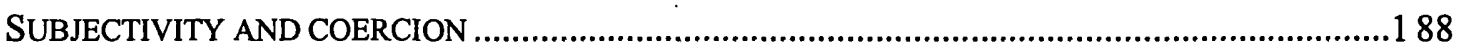

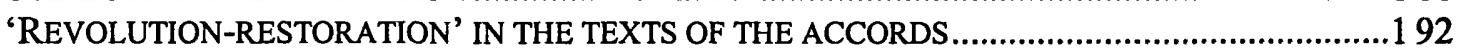

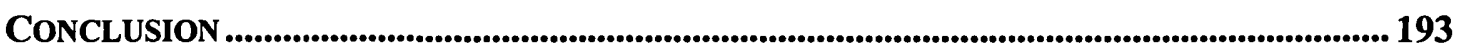

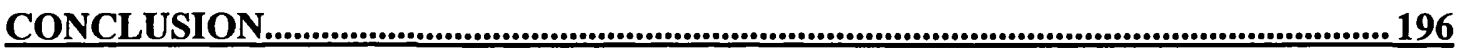

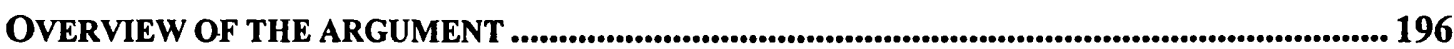

CAESARISM, IMPLEMENTATION, AND NEOLIBERALISM'S ETHICO-POLITICAL PURCHASE

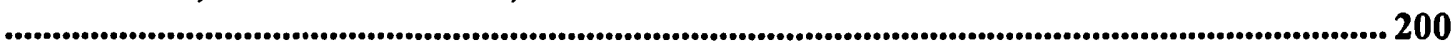

IMPLICATIONS OF A GRAMSCIAN ANALYSIS OF THE INTERNATIONAL POLITICS OF POST-

CONFLICT RECONSTRUCTION IN GUATEMALA ........................................................................209

APPENDIX 1: POLITICAL CHRONOLOGY OF GUATEMALA

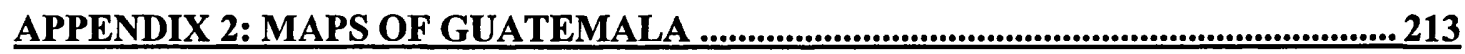

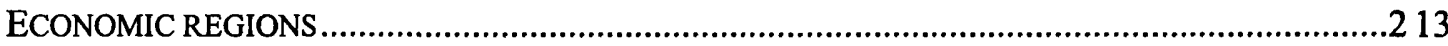

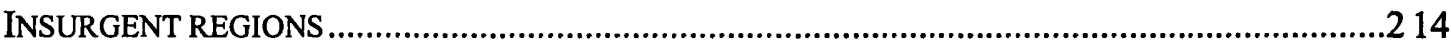

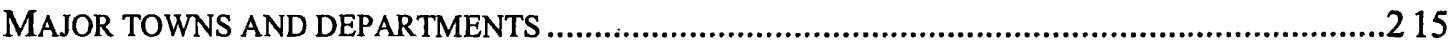

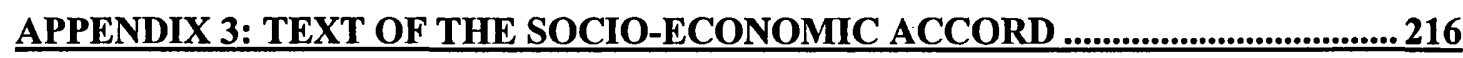

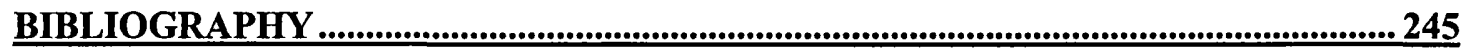




\section{Acknowledgements}

I owe many, many thanks to my supervisor, Chris Brown, for agreeing to take on this project and for his intellectual support and guidance. Thanks also to Isa Bakker and Stephen Gill for their incredible generosity and understanding in my transition to Toronto and York.

The Society for Latin American Studies and the British International Studies Association provided financial assistance for a research trip to Guatemala, for which I am very grateful. I also owe a great debt to Alex Segovia and Klarisse Guerra for their generous assistance in helping me to arrange appointments there.

Thanks to my family, without whose emotional and financial support I could not have undertaken this project. Likewise, thanks to all of my support system in London: Andrea Oelsner, Franziska Hagedorn, Nelli Kambouri for dear friendship and the special camaraderie of being in the same cohort; Louisa Odysseos, Stephan Elbe, Tarak Barkawi, for their friendship and intellectual community; Tim Dockery for his emotional support, patience and humour. Thanks to Erica Linson for being a wonderful friend. I am also very appreciative of my support system in Toronto, especially Matt Davies for feedback and encouragement in the revision process. 


\section{Introduction}

The $p$ eace process in $G$ uatemala $h$ as the potential to b ecome one of the standard-setting achievements of the second half of the twentieth century, in the same class as the Camp David Agreement between Egypt and Israel, the peace settlement in Namibia, the Paris Accords on Cambodia, and the peaceful transitions that took place in Czechoslovakia, Germany, Hungary, and Poland after the collapse of communism in the Soviet Union. It is an ambitious attempt, by visionary Guatemalans and the international community as a whole, to end an ostensibly internal conflict that has torn a country apart for almost two generations.

Sir Marrack Goulding, Former UN Under-Secretary General ${ }^{1}$

The Guatemalan peace process has been widely considered a success in academic and policy-making circles. ${ }^{2}$ It involved polarised groups in dialogue, which seemed impossible during several decades of war. It provided a development programme to modernise the economy and national infrastructure that had the support of international organisations and both sides of the negotiating table. The peace process appeared to involve widespread popular participation, and by extension reflect a significantly democratic process. In this reading, the peace process involved disenfranchised communities in national level politics, in principle enhancing both the quality of their representation and their capacity for participation.

Perhaps the greatest sense of success is associated with the perception that the peace agreements were able to address effectively the roots of the armed conflict, or the social bases of conflict (Pásara, 2001: 12); (Byrne, 1997: 3); (Goulding, 2000: xv). In its strongest formulation, this position argues that the provisions for the post-conflict

1 Sir Marrack Goulding, 'Preface', in Of Centaurs and Doves: Guatemala's Peace Process, ed. Susanne Jonas (Oxford: Westview Press, 2000), xiii.

${ }^{2} \mathrm{By}$ this is meant the negotiations of the accords, not necessarily their implementation, which has been arguably less successful (discussed further in the conclusions). 
state in the agreements provide the sort of development necessary for a broadly redistributive project in a country with abysmal social indicators - levels of poverty, access to health care and education, etc. - in both absolute terms and relative to the size of the economy (Burgerman, 2000: 81). This view particularly sees the SocioEconomic Accord as striking a balance between social and macroeconomic or structural adjustment concerns.

Another element of the sense of success regarding the Guatemalan peace process relates to the achievement of a robust statement of indigenous rights. Beyond representing an enormous accomplishment in the Guatemalan context, the far-reaching scope of indigenous rights in the agreements is seen as a model for such statements internationally. Christopher Chase-Dunn argues, for example, that 'Guatemala's accord on Identity and Rights of Indigenous Peoples ... is a conceptual breakthrough that many other countries should emulate' (Chase-Dunn, 2000: 109).

The peace process was similarly considered a success in terms of its effect on liberalising domestic politics in Guatemala. This view, related to the successes of the Indigenous Rights Accord, suggests that the negotiations themselves promoted an opening for broader civic participation in national politics, particularly among centreleft organisations and for the promotion of human rights (Armon, et al., 1997: 5-6). Suzanne Jonas uses the metaphor of springtime 'because new spaces were opening up within an exclusionary system for broader participation in politics, and indigenous and women's organizations were blossoming' (Jonas, 2000: 5). Indeed, the process is credited with cultivating a civil society 'capable of playing a leadership role in monitoring and advising the civilian government' (Burgerman, 2000: 64). 
As Sir Marrack Goulding suggests in the quote at the outset, the accomplishments of the Guatemalan peace process are not seen to be limited to the domestic sphere alone: they are considered a success of the 'international community' as well. The Guatemalan peace process is seen as a success for the United Nations (UN) on several issues. Perhaps most significantly, the UN mission for the verification of human rights in Guatemala, MINUGUA, is widely accepted as having reduced human rights abuses and created an atmosphere that allowed wider participation in the peace process than would have otherwise occurred. The UN's role as mediator was seen as both highly successful and an important development in the role of the Secretary General in the promotion of peace internationally. Susan Burgerman describes the case of Guatemala as one of the 'most illuminating examples' of 'direct intervention in the settlement of civil conflict by the United Nations (UN) Secretary General' in part because the UN mediator's conduct "extended beyond the role of "good offices" to initiating independent proposals, including recommendations for disarmament procedures, military r estructuring, and judicial and c onstitutional r eform m easures' (Burgerman, 2000: 63). Finally, the international community is seen as having succeeded in Guatemala in terms of $i$ ts c oordination on financial questions and its willingness to consider 'peace conditionality' in policies vis-à-vis Guatemala. Guatemala provided an opportunity for the UN and the international financial institutions (IFIs) to address the criticism of w orking a t c ross-purposes, which $\mathrm{h}$ ad b een $\mathrm{p}$ articularly l evelled a gainst the S alvadoran p eace p rocess (de S oto and d el C astillo, 1994). The a chievement of communication and coordination between the multilateral institutions constitutes part of the understanding of the peace process as a success of the international community.

To borrow a metaphor that Finn Stepputat uses for the post-conflict Guatemalan state, in many ways the peace process itself served as a laboratory for the UN and the IFIs to 
refine their understandings of peace negotiations and post-conflict reconstruction (Stepputat, 1999: 54). These 'trials' were considered positively conclusive: Jeremy Armon, echoing the sentiments of many, has argued that the lesson of Guatemala is that 'there is clearly a facilitatory role for the international community in bringing civil wars to an end, and nurturing the conditions for increased political tolerance and diversity' (Armon, et al., 1997: 7).

\section{Critical perspectives on the 'success' narrative}

This story nonetheless raises a number of questions regarding the grounds on which this 'success' was achieved. What fundamental political understandings of the postconflict state and society are implied by the peace accords? Are these understandings problematic if one moves away from technical considerations of reaching consensus within the peace negotiations themselves? These questions inspire a more critical reading of the Guatemalan peace process, which implies a series of counterconsiderations to the success claims outlined above. Such a posture seeks to explore, for example, how celebrating the establishment of the notion that root causes should be addressed, may depoliticise the nature of post-conflict reconstruction, and thus asks by what criteria the social bases of conflict are to be addressed. Similarly, the emphasis on achieving indigenous rights may obscure the grounds on which such rights are constructed. This c ritical perspective is likewise concerned $w$ ith the $p$ arameters and structure of domestic political liberalisation and with what principles the IFIs and the UN improve their coordination. The distinction between critical and problem-solving theories can illuminate this project of focusing attention on what is obscured by the 'success' reading of the peace process. 
Problem solving theories 'take the world as they see it' and aim to make 'relationships and institutions work smoothly by dealing effectively with particular sources of trouble' (Cox, 1981: 129). Thus, problem-solving knowledge tends to result in a reproduction of the status quo (Patomaki, 2001: 727). Problem solving theory engages with a 'continuing present' in the form of 'the permanence of the institutions and power relations which constitute its parameters' (Cox, 1981: 129). As Robert Cox observes, problem-solving theory's ahistoricity is not merely a convenience of method, but also an ideological bias', problem solving theory may be 'methodologically value-free insofar as it treats the variables it considers as objects (as the chemist treats molecules or the physicist forces and motion); but it is value-bound by virtue of the fact that it implicitly accepts the prevailing order as its own framework' (Cox, 1981: 129-30).

Critical theories, by contrast, $s$ tand ' apart for the p revailing o rder of the w orld and [ask] how that order came about' (Cox, 1981: 129). As captured in Robert Cox's famous dictum, 'theory is always for someone and for some purpose', the purpose of a critical theoretical perspective is to uncover the interests behind dominant understandings of the status quo (Cox, 1981: 128). '[Critical theory] is directed towards an appraisal of the very framework for action, or problematic, which problemsolving accepts as its parameters' (Cox, 1981: 129). In their attention to social transformation, critical theories engage with an historical account that actively incorporates both a description of the past and a description of historical change. Where problem-solving theories take social and political institutions as 'given', critical theories seek to analyse them in terms of their histories, interrelationships and processes of transformation. A critical perspective thus implies understanding how power is constructed historically and how power relationships become naturalised or 
obscured. Where problem-solving theory establishes narrow parameters on its analytical remit, critical theory seeks to establish a holistic understanding: 'the critical approach leads towards the construction of a larger picture of the whole of which the initially contemplated part is just one component, and seeks to understand the processes of change in which both parts and whole are involved' (Cox, 1981: 129). Finally, as the above would imply, critical theory differs from problem-solving theory in its posture towards epistemology. Given its understanding of the necessity of a normative position in every theory, critical theory rejects the fact-value distinction associated with problem-solving theory's generally positivist methods.

\section{A Gramscian reading of the Guatemalan peace process}

Given the issues at stake in the Guatemalan peace process, a critical reading should be equipped to engage with an account of the social bases of conflict in full historical and international dimension, of the ethico-political status of cultural difference, the nature of popular political participation, and the nature of the relationship between the international community and 'domestic' peace processes, in other words, an account of world order. The political theory of early twentieth century socialist, Antonio Gramsci, explored further in Chapter 2, provides tools for such an analysis. The point of departure for Gramsci's analysis is historical materialism, from which he develops several conceptual tools for the critical analysis of politics and society: innovative understandings of the 'state', political power, and political subjectivity.

The success story emphasises the social bases of conflict within problem-solving parameters that locate conflict in the dysfunctional state and obscure the historical and international dimensions of conflict as well as the construction of the state itself. 
Gramsci understood the state in broad terms of the operation of political power: the 'integral state' involves both civil society and political society, the narrow, conventional understanding of the state. For Gramsci, governance transcends the institutional and is understood in broad political-socio-economic terms: the emphasis is on understanding the 'ensemble of social relations'. Central to Gramscian analysis, then, is a rejection of the assumption that civil society exists necessarily in opposition to political society; rather, these spheres are intricately related in the operation of power within the ensemble of social relations.

The targeting of civil society as a sphere for foreign policy intervention thus is quite significant to a Gramscian analysis. William I. Robinson suggests that US policymakers appreciate the political power of civil society, making it the site for the "new interventionism' (Robinson, 1996: 28-29). Multilateral organisations have also engaged in 'targeting' civil society. These interventions often serve neoliberal political economic goals (Biekart, 1999: 175, 211).

The integral state and the ensemble of social relations are helpful for conceptualising the nature of the state and governance in the 'periphery', because they allow for an appreciation of the complex political, economic and social relationships implied by global hierarchies in 'development'. The structures of 'peripheral' economies, particularly those dependent on exports from agriculture or mining, involve complex relationships in civil and political society both 'domestically' and 'internationally' that construct the possibilities for politics. In such cases of disarticulation (see below), political decision-making is highly contingent on conditions and agents outside of the narrow, institutional state. Indeed, the very conceptions of modernisation and development that condition the peripheral state's raison d'etat, internal and external 
relationships are constructed through a dynamic informed by 'domestic' realties and considerations of a larger political-economic-cultural order. Perspectives on conflict in the periphery, furthermore, to a large extent involve an assessment of the problematic of modernisation and development. (As is discussed further in Chapter 3, counterinsurgency warfare results from tensions of a particular understanding of modernisation in disarticulated conditions.)

Gramsci's most notable contribution to understanding politics was his concept of hegemony, a sophisticated account of the operation of power through a combination of force and suasion. Hegemony describes a situation of successful 'intellectual and moral leadership' such that dominant groups that hold the coercive power in society need not use it to exercise their dominance but may rely on the consent of subaltern groups. Whether or not conditions of hegemony actually obtain, its constituent elements are illuminating for the understanding of political power. In his analysis of the nature of consent, Gramsci drew attention to questions of political consciousness and subjectivity, key factors in the operation of political power.

Gramsci's understanding of politics - located both in political and civil society, associated with questions of suasion and consciousness - is intricately related to questions of culture. This, along with his critique of positivism and teleology, provide a lens with which to see both the historically and materially constructed dimensions of racial and cultural difference as well as the ethico-political grounds on which such difference might be approached. The holistic perspective sought by critical theory is captured in Gramsci's notion of the historical bloc, the mutually reinforcing institutionalisation of the political and cultural dimensions of a particular socioeconomic order. 
The Gramscian reading of the Guatemalan peace process offered in the chapters that follow emphasises the historical and international dimensions of the 'social bases of conflict' and their relationships to peripheral conditions of disarticulation. It sees the definition of democracy and liberalisation in domestic politics as the result of evolving circumstances that established particular parameters that would limit the possibilities for social transformation. In this reading, the negotiations themselves construct parameters around fundamental questions such as the nature of cultural rights and their relationship to socio-economic questions. The nature of the post-conflict state implied by the texts of the agreements involves the reconstruction of society as subordinate to. the market at the institutional and subjective levels.

This alternative, critical reading understands conflict in terms of the tensions and contradictions within the disarticulated ensemble of social relations (see Chapter 3). Disarticulated economies are export-oriented and rely on coercive labour relations (within the ostensive rubric of free labour); disarticulation reflects both the 'objective' economic conditions of this exploitation, as w ell as the 'subjective' s ocial r elations that emerge, including class, race, and cultural (e.g., 'modern'/'traditional') hierarchies. Historically dominant theories of modernisation have sought to industrialise disarticulated societies through the maintenance of such social hierarchies. They conceptualise resistance to such modernisation in terms of the destabilising effects of social transformation on 'traditional' social patterns rather than a rejection of the underlying social hierarchies and the rationales through which they are defended. Thus dominant theories of modernisation are associated with conceptions of how to secure society during times of transformation, embodied in theories of counterinsurgency. 
The counterinsurgent state in Guatemala, established by domestic elites and the US as a reaction against attempts to challenge the disarticulated social order, would ultimately suffer a crisis of its own contradictions (discussed further in Chapter 4). This crisis would be addressed through the related phenomena of a domestic democratisation process and a regional peace processes. The latter would reconstruct involvement in the region, giving parameters to what could be called the 'international community': bilateral involvement of the US and European states, multilateral involvement of the EU, the IFIs and the UN. The domestic return to civilian rule reflected a pact to reassert economic elites' interests while preserving key elements of military power. The regional peace process established an anaemic understanding of democracy constructed to discipline the revolutionary movement in Nicaragua. These processes would result in Guatemala's domestic peace process, which would be limited by prior understandings of questions such as the nature of democratic participation and the need to rebuild the political centre.

The peace process can be understood in two dimensions: the negotiations of the agreements (which occur in several phases) and the vision of the post-conflict state as constructed through the texts of the accords. The negotiations reflect the operation of political power to preserve e lite interests, as a Gramscian analysis helps i lluminate. They involved the strategic use of civil society to cultivate consent for the peace process, within parameters that established the need for consensus around the political centre: opportunities for participation consistently led to the attenuation of popular demands. The negotiations also consistently deferred socio-economic considerations in their engagement with political questions, constructing an understanding of rights as an exclusively political problematic. 
The negotiations reflect the elite management of a moment of social transformation, but one of competing perspectives that leaves the peace process itself on unstable, contested terrain. Thus the texts of the accords articulate a view of the post-conflict state that reflects a coalition of interests constructed around a particular resolution of the contradictions of counterinsurgency: a resolution based on the conception of neoliberal modernisation shared by certain economic elites and international actors. In this reading, social investment per se cannot be considered a compromise between neoliberalism and addressing 'the root cases of conflict': the nature of what is being (re)constructed through such investment must be observed. The texts of the Guatemalan a ccords reflect the reconstruction of the $G$ uatemalan s tate in $n$ eoliberal terms. It emphasises market mechanisms for the resolution of distributional questions particularly vis-à-vis land, a key question in the conflict. However, in its social investment patterns as well, the provision of spending is predicated on the 'reorganisation of the rural population for production', that is the construction of neoliberal subjectivity as a requirement for participation in the post-conflict state.

The accords therefore reflect a very thin resolution of disarticulated counterinsurgency. They address the objective conditions of disarticulated agricultural production only at the margin, in the rural population beyond the finca, while they engage with the 'subjective' dimension of counterinsurgency through the incorporation of 'dangerous' groups (the indigenous and the guerrilla) though a regime of rights and reintegration. However, this solution is one that in fact further erodes the autonomous bases for indigenous society and subjects it - as with Guatemalan society as a whole - to market rationality, such that the grounds for the preservation of indigenous culture is its commodification. 
Although this resolution does to a degree reflect the 'genuine' construction of consent between economic elites and the guerrilla based largely on achievements understood in terms of the success claims outlined above, it is unstable as the result of the very logic that preserved elite influence in the peace process. This logic - which among other strategies relied upon an unreformed electoral system to endorse the resolution of 'essential' economic and military issues - maintained not only the position of modernising economic elites but of other powerful groups that would challenge this resolution of disarticulation as well.

\section{Peace processes and the (re)construction of world order}

In the reading offered here, ultimately the Guatemalan peace process reflects the (re)construction of the post-conflict state in neoliberal terms through a coalition of international a ctors, Guatemalan e conomic elites and the guerrilla. $\mathrm{N}$ eoliberal peace processes reflect a certain 'reflexive' process of the (re)construction of neoliberalism: the 'international community' assists in the reconstruction of the state in neoliberal terms, while the neoliberal state in turn contributes to the (re)construction of a neoliberal world order.

The issue of neoliberalism's impulse to reconstruct the state is not entirely new for Gramscian analyses of world politics. Robert W. Cox's classic analysis of the relationship between states and world orders examined the dynamics between internal and external pressures on states to maintain their compatibility with global economic conditions. Stephen Gill's work on disciplinary neohberalism and William I. 
Robinson's work on authoritarian-democratic transitions also provide analyses to some extent animated by this concern.

Robert Cox has used Gramscian analysis to examine the relationship between the state and world order. In his schema, the state is the product both of internal forces ('the configuration of social classes within a historic bloc', discussed further in Chapter 2) and external forces ('the permissiveness of the world order', which 'tends to limit forms of state to those that are compatible with the prevailing social structure of accumulation') (Cox, 1987: 147-8, 209-10). For Cox, because the state is a reflection of social classes, raison d'etat is an expression of the organisation of production: transformations in production relations are related to changes in the form of state and the raison d'etat (Cox, 1987: 106).

In Stephen Gill's account of neoliberalism, the e conomic project of liberalisation is accompanied by a political project of restructuring the state and international organisations. This political project, the 'new constitutionalism', operates through conditionality, 'quasi-institutional r egional a rrangements' a nd m ultilateral r egulatory frameworks such as the WTO (Gill, 1995: 412). Central to this is 'the imposition of discipline on public institutions, partly to prevent national interference with the property rights and entry and exit options of holders of mobile capital with regard to particular political jurisdictions' (Gill, $1995: 413){ }^{3}$ The political p roject of the $n$ ew

\footnotetext{
${ }^{3}$ Among other privileges for capital, Gill suggests that the new constitutionalism has involved the restructuring of taxation in the OECD and elsewhere, in ways that reduce the relative taxation of capital while attempting to broaden the individual tax base, 'in order to create a more "activist tax state" with increasingly regressive taxes'. Stephen Gill, Power and Resistance in the New World Order (Basingstoke: Palgrave Macmillan, 2003), 136-7. Taxation is a long-standing question in Guatemala and central to the question of peace conditionality, as discussed further in the Conclusion.
} 
constitutionalism is necessary because, 'whereas capital tends toward universality, it cannot operate outside or beyond the political context, and involves planning, legitimation and the use of coercive capacities of the state' (Gill, 2003: 141).

Gill argues that 'neo-liberal forms of discipline are not necessarily universal nor consistent, but they are bureaucratized and institutionalized, and operate with different degrees of intensity across a range of "public" and "private" spheres, in various state and civil society complexes. Discipline in this sense is both a transnational and a local dimension of power' (Gill, 2003: 130-1). This is underwritten by certain values and orientations - 'new constitutionalist proposals are often implicit rather than explicit' such as market efficiency, discipline, confidence, economic policy consistency, limitations on democratic decision-making processes (Gill, 1995: 412). Indeed, for Gill, the cultural component of disciplinary neoliberalism reflects Marx's commodityfetishism in that capitalist commercialization conditions outlooks, identities, timehorizons and conceptions of social space (Gill, 2003: 120).

William I. Robinson has argued that world-wide transitions from authoritarianism to democracy in the 1980s and 1990s, and the shift in US support for the former to the latter, reflects the changing needs for social control required by transnational capital. Fundamentally, authoritarian regimes became seen as inefficient for providing political stability in the face of democratisation movements generated by changing social and economic roles associated with globalisation (Robinson, 1996: 38). The US policymaking elite, acting on behalf of the interests of a transnational elite, responded to such movements with the promotion of a particular, narrow understanding of democracy, where political contestation is limited to elections involving a selection of elite-determined choices ('polyarchy'), as well as an emphasis on political intervention 
into civil society to reconstruct it as an arena to buttress elite political projects (Robinson, 1996: 28-29). ${ }^{4}$

The reading of the Guatemalan peace process offered here draws on and is animated by many of the same concerns as the works of Cox, Gill and Robinson, however it differs in scope, most significantly vis-à-vis the issue of political subjectivity. Peace processes, particularly those that emphasise addressing the social bases of conflict, offer a uniquely profound opportunity to reconstruct the state. As the analysis of the texts of the accords in Chapter 4 illustrates, this possibility can be seen to operate at the most fundamental level of political subjectivity. In the Guatemalan peace process, the 'reorganisation of the rural population for development' extends the 'capillary power' of capitalism that Gill describes to the level of constructing political subjectivity.

The analysis presented here largely accepts Cox's arguments about the relationship between the stae and the interstate system. This reading also resonates with Gill's observations about the cultural dimension and values animating neoliberalism, while the specific technologies of consent found in the negotiations shares much with Robinson's analysis of the promotion of polyarchy. However, it combines questions of the cultural status of neoliberalism and its values - more profoundly its subjectivity and rationality - and the question of its construction within North-South relations and the development problematic. To do so it relies on an appreciation of the subjective dimension of political-economy at the macro-economic level through Alain de

4 As discussed in Chapter 2, although sympathetic to Robinson's project in many respects, his attempt to integrate world systems theory with a Gramscian analysis conflicts with the analytical framework offered here. 
Janvry's understanding of the disarticulated developing economy and at the level of individual rationality through neoliberal conceptions of homo economicus.

Questions of culture and subjectivity have been central elements of the 'development problematic', both in its formulation as an object of academic study as well as the longer-standing historical questions of the encounter between the 'modern' and the 'traditional' (the European and the indigenous) in Latin America and globally. ${ }^{5}$ These divisions are of enormous significance for the structure of the ensemble of social relations and the ontology and nature of political violence in Guatemala. Appreciating the subjective dimension of the post-conflict state (and by extension global order) is central to understanding the efficacy of the construction of neoliberalism in the periphery and, from a Gramscian perspective, how to resist it.

In what follows, a Gramscian framework for understanding contemporary peace processes is developed in Chapter 2. Chapter 3 examines the historical-material development of the Guatemalan ensemble of social relations into one of counterinsurgent disarticulation. Chapter 4 then describes how the crisis of counterinsurgent disarticulation and regional peace processes converge to construct the Guatemalan $p$ eace $p$ rocess, the n egotiations of the $p$ eace $p$ rocess and the $n$ eoliberal accords it produces. Finally, the Conclusion considers the implementation of the accords and implications that has on understanding the international politics of postconflict reconstruction.

${ }^{5}$ For an overview of the intellectual history of development studies, see: Tariq Banuri, 'Development and the Politics of Knowledge: A Critical Interpretation of the Social Role of Modernization Theories in the Development of the Third World', in Dominating Knowledge: Development, Culture and Resistance, ed. Federique Apffel Marglin and Stephen A. Marglin (Oxford: Oxford University Press, 1990). 


\section{Gramscian Politics and the Study of Peace Processes}

This chapter provides a reading of the work of the Italian political theorist Antonio Gramsci to construct a framework for examining the international politics of postconflict reconstruction in Guatemala. ${ }^{6}$ Gramsci's Prison Notebooks - his greatest contribution to political theory, written while incarcertated under fascist government, 1926-1937 - might be characterised as exploring the nature of politics and power in terms of three interrelated dimensions: the institutional, the subjective and the historical. Gramsci problematises conventional understandings of the institutional dimension of politics through an expanded notion of state and an appreciation of the sociological and cultural dimensions of politics. He understands power to be historically, materially, and subjectively (re)constructed, a dynamic that constitutes the terrain of politics and possibilities for social transformation.

${ }^{6}$ The following relies heavily on Quintin Hoare and Geoffrey Nowell Smith's selections from and translations of the Prison Notebooks. Antonio Gramsci, Selections from the Prison Notebooks of Antonio Gramsci, ed. Quintin Hoare and Geoffrey Nowell Smith, trans. Quintin Hoare and Geoffrey Nowell Smith (London: Lawrence and $\mathrm{W}$ ishart, 1991). This translation, o riginally published in 1971 and r eprinted six times, is widely respected as one of the most thorough English-language collections of these works. E.J. Hobsbawm, 'The Great Gramsci', The New York Review of Books, April 4 1974, 39. Hoare and Nowell Smith have also translated selections from Gramsci's political writings 1910-20 and 1921-26 Antonio Gramsci, Selections from the Political Writings 1910-1920, ed. Quintin Hoare, trans. John Mathews (London: Lawrence and Wishart, 1977); Antonio Gramsci, Selections from the Political Writings 1921-1926, ed. Quintin Hoare, trans. Quintin Hoare (London: Lawrence and Wishart, 1978). A collection of Gramsci's cultural writings is found in Pedro Cavalcati and Paul Piccone, eds., History, Philosophy and Culture in the Young Gramsci (St. Louis: Telos Press, 1975). David Forgacs provides a collection of shorter excerpts of Gramsci's original works in, David Forgacs, ed., A Gramsci Reader: Selected Writings 19161935 (London: Lawrence and Wishart, 1988). The most comprehensive collection of commentaries on Gramsci's political theory can be found in Martin James' four volume series. Martin James, ed., Antonio Gramsci: Critical Assessments of Leading Political Philosophers, 4 vols. (London: Routledge, 2002). Joan Nordquist, ed., Antonio Gramsci: A Bibliography, Social Theory: A Bibliographic Series (Santa Cruz, CA: Reference Research Services, 1987), while a bit dated, includes works by and about Gramsci as well as references to reviews of such works. Giuseppe Fiori's biography is considered the definitive description of Gramsci's life available in 
The following provides a reading of Gramsci's understanding of politics, above all his understanding of hegemony and its constituitive elements, coercion and consent, intellectual and moral leadership, political subjectivity, Gramsci's understanding of power and the relationship between politics and culture. How these relate to questions of the state and world order is then considered, with particular attention to the world order and raisons d'etat implicated in the Guatemalan case. The reading of Gramsci offered here incorporates features of this thought that have conventionally be disaggregated in different academic disciplines (e.g., cultural studies, anthropology, international political economy). As a theorist of political economy, culture, and political subjectivity, Gramsci provides a framework highly suited to examining developing countries in general and Guatemala in particular, where the 'ensemble of social r elations' is h istorically rooted in $\mathrm{p}$ atterns of e conomic production a ssociated with cultural and racial hierarchies. Such conditions, furthermore, are understood to be related to the 'social bases of conflict', and are central to understanding the peace process and reconstruction plans for the post-conflict state.

English, Guiseppe Fiori, Antonio Gramsci: Life of a Revolutionary, trans. Tom Narin (New York: E.P. Dutton \& Co., 1971). A simpler introduction to Gramsci's life and work is found in Anne Showstack Sassoon, ed., Approaches to Gramsci (London: Writers and Readers, 1982), while a brief introduction to his politics can be found in Roger Simon, Gramsci's Political Thought (London: Lawrence \& Wishart, 1991). Walter L. Adamson, Carl Boggs and Alastair Davidson all have written book-length treatments of Gramsci's life and politics: Walter L. Adamson, Hegemony and Revolution: A Study of Antonio Gramsci's Political and Cultural Theory (Berkeley: University of California Press, 1980); Carl Boggs, The Two Revolutions: Antonio Gramsci and the Dilemmas of Western Marxism (Boston: South End Press, 1984); Alastair Davidson, Antonio Gramsci: Towards an Intellectual Biography (London: Merlin Press, 1977); while Anne Showstack Sassoon, Gramsci's Politics (Minneapolis: University of Minnesota Press, 1987) focuses more exclusively on his politics. 


\section{Hegemony and Gramscian politics}

Gramsci's most noted contribution to political theory is his conception of hegemony.? Gramscian hegemony reflects a particular strategy of governance that rules predominantly through consent, yet with the ever-present possibility of coercion to protect the dominant order. Hegemony thus reflects the importance of the culturalideological or 'superstructural' element of governance. However, at the same time, the possibilities for rule are historically and materially constructed, thus always linked to an economic order that informs the nature of power in such a system. To appreciate the complexity of hegemony it is helpful to recognize three elements of its operation: the relationship between coercion and consent, Gramsci's notion of intellectual and moral leadership, and political subjectivity.

\section{Coercion and consent}

A key feature of hegemony is the relationship between coercion and consent. Coercion reflects the direct power a ruling group wields in society, while consent reflects the ideological p ower of intellectual, m oral and $\mathrm{c}$ ultural u nderstandings that favour that group.

\footnotetext{
${ }^{7}$ For discussions of the history and genealogy of hegemony with reference to Gramsci see, in addition to the survey works cited above: Ernesto Laclau and Chantal Mouffe, Hegemony and Socialist Strategy: Towards a Radical Democratic Politics, 2nd ed. (London: Verso, 2001); Peter Ghosh, 'Gramscian Hegemony: An Absolutely Historicist Approach', History of European Ideas 27, no. 1 (2001); Chantal Mouffe, ed., Gramsci and Marxist Theory (London: R outledge and Kegan P aul Ltd., 1979); Joseph A. Woolcock, 'Politics, Ideology and Hegemony in Gramsci's Theory', Social and Economic Studies 34, no. 3 (1985); Thomas R. Bates, 'Gramsci and the Theory of Hegemony', Journal of the History of Ideas 36, no. 2 (1975); Joseph Femia, 'Hegemony and Consciousness in the Thought of Antonio Gramsci', Political Studies 23, no. 1 (1975); James, ed., Antonio Gramsci: Critical Assessments of Leading Political Philosophers, volume 2, part 8.
} 
Hegemony manifests itself as 'spontaneous consent' for 'the general direction imposed on social life by the dominant fundamental group'. State coercion exists to guarantee this 'natural' social condition: 'The apparatus of state coercive power ... "legally" enforces discipline on those groups who do not "consent" either actively or passively. This apparatus is, however, constituted for the whole of society in anticipation of moments of c risis of command and direction when spontaneous consent $\mathrm{h}$ as failed' (Gramsci, 1991: 12). Thus, the legitimacy of coercion is constructed around a specific social order. Force, 'domination', is a resource held by the ruling groups but its legitimate use is a shared construction of dominant and subordinate groups.

Hegemony requires that a potentially dominant group express its narrow corporate interests in universal terms that appeal to the larger socio-political unit, which unifies different groups' social and political aims under an ideology that ultimately privileges the hegemonic group (Gramsci, 1991: 181-2). The political purchase of hegemonic concepts comes from their ability to seem universal, in the interest of all. Thus, 'the development and expansion of the particular group are conceived of, and presented as being the motor force of a universal expansion, of a development of all the "national" energies' (Gramsci, 1991: 181-2). An example from international relations might be Britain $1845-65$, as its conception of international economic order was effectively expressed in universal terms - 'comparative advantage, free trade and the gold standard' - and underwritten by Britain's position in Europe and her navy further afield (Cox, 1993: 60). This hegemony involved 'the capacity to claim with credibility that the expansion of the United Kingdom served not just its national interest but a "universal interest" as well' (Arrighi, 1993: 174). Hegemony expresses the shared political understandings of dominant and subordinate groups. The dominant group controls the apparatuses of force in society, however, the social order is accepted and 
equally reproduced by subordinate groups. Hegemony is 'ethico-political' in that cultural factors are as important as economic and political ones in its justification. Yet Gramsci qualifies this Crocean element by reiterating that 'the philosophy of praxis [Marxism] thus judges the reduction of history to ethico-political history alone as improper and arbitrary, but does not exclude the latter' (Forgacs, 1988: 195). ${ }^{8}$

The universalisation stage is the most 'purely political phase' of hegemony, and the universal expression of the hegemon's interests may involve specific concessions to subaltern groups (Gramsci, 1991: 181). The hegemonic group may need to modify implicitly its goals to accommodate those of other groups. Such compromises are of an 'economic-corporate' kind, they do not 'touch the essential', i.e., the economic order at the root of a society. '[T]hough hegemony is ethico-political, it must also be economic, must necessarily be based on the decisive function exercised by the leading group in the decisive nucleus of economic activity' (Gramsci, 1991: 161). The concessions inherent in the notion of consent in hegemony are made precisely to preserve the social order, not to empower marginalized groups. Though dynamic in its expression, ultimately hegemony protects a particular economic order.

Hegemony is a condition of power that does not require the direct exercise of force, although it does require the continuous leadership of a dominant group:

A social group can, and indeed must, already exercise 'leadership' before winning governmental power (this indeed is one of the principal conditions for the winning of such power); it subsequently becomes dominant when it

\footnotetext{
${ }^{8}$ This is Forgacs' own translation of one of the Prison Notebooks (Quaderno 10, I§12), and does not refer to a particular work by Croce; Croce did nonetheless write a volume specifically on ethics and p olitics: B enedetto C roce, E tica e politica (Bari: Laterza, 1931), in English, Benedetto Croce, Politics and Morals, trans. Salvatore J. Castiglione (New York: Philosophical Library, 1945).
} 
exercises power, but even if it holds it firmly in its grasp, it must continue to 'lead' as well (Gramsci, 1991: 57-58).

Hegemony must be continually renewed through the exercise of intellectual and moral leadership, and such leadership requires understanding and appealing to the interests of subordinate groups. The coercive threat underpinning the hegemonic group's dominance only appears when the system breaks down. Thus, as Robert Cox puts it, 'coercion is always latent but is only applied in marginal, deviant cases. Hegemony is enough to ensure conformity of behaviour in most people most of the time' (Cox, 1993: 52).

\section{Intellectual and moral leadership}

The leadership implied by Gramsci's understanding of hegemony moves beyond conventional $\mathrm{M}$ arxist $\mathrm{n}$ otions of $\mathrm{c}$ lass a lliances. Here $\mathrm{l}$ eadership is a $\mathrm{n}$ undetermined intellectual process that actively engages subaltern groups in articulating a worldview that responds to their 'common sense'. In so doing, it challenges notions of a pre-given political subject as well as economistic understandings of Marxism.

There is little in the Prison Notebooks on the specifics of intellectual and moral leadership' (Gramsci, 1991: 57). It is conceivable that this is because different groups will employ different techniques based on the class interests that they reflect. Nonetheless, the meaning and parameters of intellectual and moral leadership may be inferred from the extensive discussions of philosophy, ideology and common sense.

Gramsci argues that 'All men are intellectuals ... but not all men have in society the function of intellectuals' (Gramsci, 1991: 9). Those that 'function' as intellectuals reflect historically formed social groups that make up a social order (Gramsci, 1991: 
10). Intellectuals are socially situated: each group may produce its own 'organic' intellectuals. However, intellectual activity is a complex exchange between the 'common sense' of one's lived experience and 'ideological superstructures' that shape society. The intellectual process is complex and "'mediated" by the whole fabric of society and by the complex of superstructures' (Gramsci, 1991: 12). Thus there is a dialectic between an intellectual's background and the attraction of intellectual activities of other groups. The more important social groups are able to promote 'more extensive and more complex elaboration' of their positions (Gramsci, 1991: 10). This power of attraction can end up 'subjugating the intellectuals of other social groups ...thereby creat[ing] a system of solidarity between all the intellectuals, with bonds of a p sychological nature (vanity, etc.) and often of $\mathrm{c}$ aste $\mathrm{character}$ (technico-juridical, corporate, etc.)' (Gramsci, 1991: 60).

Knowledge is infused with the social categories of society and the power relationships that they imply. As Stephen Gill notes, based on Robert Cox's famous observation, 'by linking a theory of knowledge to a theory of identity and interests, Gramsci was able to show how ... theory is always for someone and for some purpose' (Gill, 1993: 25). Intellectuals, although potentially counter-hegemonic, more often serve as "“deputies" exercising the subaltern functions of social hegemony and political government' for the dominant group, generating 'spontaneous' consent and justifying state coercion (Gramsci, 1991: 12). Indeed, Gramsci uses the term intellectual to mean anyone who actively articulates rationales for the political-social order, whose ranks have greatly expanded in the modern era. 'The democratic-bureaucratic system has given rise to a great mass of functions which are not all justified by the social necessities of production, though they are justified by the political necessity of the dominant fundamental group' (Gramsci, 1991: 13). 
For intellectual activity to have any leadership potential it must be compatible with the 'common sense' of the groups to be influenced. Common sense captures 'the conception of the world which is uncritically absorbed by the various social and cultural environments in which the moral individuality of the average man is developed' (Gramsci, 1991: 419). This phenomenon reflects the accumulation of conventional wisdom over time: it is a reflection of dominant cultural and historical legacies in a society (Gramsci, 1991: 325-6). Only philosophies that engage with common sense can become historically effective. As Stuart Hall puts it: 'formal coherence cannot guarantee [an ideology's] organic historical effectivity. That can only be found when and where philosophical currents enter into, modify and transform the practical, everyday consciousness or popular thought of the masses' (Hall, 1996: 431).

Intellectual leadership involves the articulation of the (actually or potentially) dominant group's political project in terms that resonate with the common sense of other groups. This articulation may come from a number of sources, including subordinated members of hegemonic institutions. For example, Gramsci observes that subaltern groups in the military demonstrate the most conspicuous allegiances to the hegemonic project (Gramsci, 1991: 13fn). ${ }^{9}$

9 'Here again military organisation offers a model of complex gradations between subaltern officers, senior officers and general staff, not to mention the NCO's, whose importance is greater than is generally admitted. It is worth observing that all these parts feel a solidarity and indeed that it is the lower strata that display the most conspicuous esprit de corps, from which they derive a certain "conceit" which is apt to lay them open to jokes and witticisms'. Gramsci, Selections from the Prison Notebooks of Antonio Gramsci, $13 \mathrm{fn}$. 


\section{Political subjectivity}

Gramsci understands ideas as material forces that create political consciousness and political subjects (Gramsci, 1991: 365); (Mouffe, 1979: 185). Therefore, 'social classes that exist at the economic level, are not duplicated at the political level; instead, different “inter class" subjects are created' (Mouffe, 1979: 189). Political subjects are constructed through ideology and culture, they are not ontologically given. An individual may have competing political identities, but consciousness is also a collective phenomenon, 'a consequence of the relationship between "the self" and the ideological discourses which compose the cultural terrain of society' (Hall, 1996: 433).

Gramsci conceives of consciousness as grounded both in the actual, material circumstances of real life, as well as in one's socialisation, which he describes as 'two theoretical consciousnesses' (Gramsci, 1991: 333). ${ }^{10}$ This latter element, one's received understandings of the world, may be as powerful and meaningful as the former. This received conception of one's self creates collective identities and conditions one's propensity for political action (in potentially debilitating ways: 'often powerfully enough to produce a state in which the contradictory state of consciousness does not permit any action ... and produces a condition of moral and political passivity' (Gramsci, 1991: 333)). Gramsci does see transformative potential in the critical understanding of oneself, which 'takes place through a struggle of political "hegemonies", but the outcome of this struggle may not be guaranteed (Gramsci, 1991: 333).

\footnotetext{
${ }^{10}$ James Scott's critique of hegemony (which does not engage directly with Gramsci's texts) is in fact based on an argument akin to Gramsci's two consciousnesses. Much of what he attributes to 'hegemony' in his critique would be understood as domination in the reading of Gramsci offered here. James C. Scott, Weapons of the Weak: Everyday Forms of Peasant Resistance (New Haven: Yale University Press, 1985).
} 
Gramsci provides a nonessentialised account of collective identities. Collective identities exist, but not in a static, ahistorical, ontologically-given way as per the 'clash of civilisations' thesis and related understandings of culture and ethnicity in $\mathbb{R}$ (Huntington, 1993). Nor do identities simply exist as a reflection of economic production, as much classical Marxism assumes. The production of knowledge and culture that sustains identities is a dynamic, collective, social phenomenon. Identities are always tied to the socio-economic conditions that give rise to them, yet class is only one element of identity and, as with all elements, heterogeneous and fluid, contingent on the ensemble of social relations in an historical moment. Nonetheless, as 'common sense' involves the residues of historical understandings, we must appreciate that this 'fluidity' may in fact be quite viscous.

In sum, we cannot expect political identification on the basis of any purely 'rational' category, such as class or an 'obvious' condition of exploitation such as in Ché Guevara's foco theory. ${ }^{11}$ As Stuart Hall argues, "This complex, fragmentary and contradictory conception of consciousness is a considerable advance over the explanation by way of "false consciousness" more traditional to marxist theorizing but which is an explanation that depends on self-deception and which he rightly treats as inadequate' (Hall, 1996: 433). Political identification occurs in terms that are salient to a specific collective sense of history and society, whose transformation - as it is constructed by both dominant and subaltern groups - is psycho-socially complex.

${ }^{11}$ For discussions of foco theory, see: 'Guerrilla Warfare' in Rolando E. Bonachea and Nelson P. Valdes, eds., Che: Selected Works of E rnesto Guevara (Cambridge: MIT Press, 1969), Michael Lowy, The Marxism of Che Guevara: Philosophy, Economics and Revolutionary Warfare, trans. Brian Pearce (New York: Monthly Review Press, 1973), particularly part III, 75-113, Léo Sauvage, Che Guevara: The Failure of a Revolutionary, trans. Raoul Frémont (Englewood Cliffs, NJ: Prentice-Hall, 1973), 170-80. 
Gramsci's p olitical thought a llows u s to se e h ow e conomic s ystems produce varied political identities that may not conform to traditional notions of class. Central among these facets of complex political identities is the notion of race. Gramscian analysis can be fruitfully employed to engage with race and class as related social constructs, as has been shown by above all Stuart Hall. He argues,

The e thnic and racial s tructuration of the labour force, like its gendered composition, may provide an inhibition to the rationalistically conceived 'global' tendencies of capitalist development. And yet, these distinctions have been maintained, and indeed developed and refined, in the global expansion of the capitalist mode (Hall, 1996: 436).

With this perspective in mind, 'backwards', marginalized sectors in a social formation becomes sites for critical analysis. Hall reflects on practices of incorporating 'backwards' sectors - e.g. peasant economies in industrialising Latin American societies, Gramsci's Sardinia, or apartheid era 'Bantustans' - into more 'advanced' economic structures: 'Theoretically what needs to be noticed is the persistent way in which these specific, differentiated forms of "incorporation" have consistently been associated with the appearance of racist, ethnically segmentary and other similar social features' (Hall, 1996: 437, emphasis original).

A Gramscian approach can appreciate the material import of racism as an ideological structure that conditions subjects (both as beneficiaries and victims of race hierarchies) into a cultural understanding of race that obscures its economic functions. It illustrates the operation of power through knowledge and identity.

\section{Economism, positivism, teleology}

Gramsci's complex understanding of politics, with its dimensions of consent, intellectual and moral leadership, and subjectivity, clearly conflicts with 
understandings of history as exclusively economically determined. The Prison Notebooks contain an explicit critique of 'economism' grounded in his readings of the early writings of Marx and Engels. The dynamic between economics and ideology 'must be accurately posed if the forces which are active in the history of a particular period are to be correctly analysed and the relations between them determined' (Gramsci, 1991: 177). In Gramsci's view, the Second International misinterpreted Marx to understand that capitalism's contradictions would lead inevitably to revolution, based on a positivist epistemology that saw the validity of Marxism in terms of the empirical efficacy of his analysis (Mouffe, 1979: 173).

Gramsci's critique of economism is related to that of positivism. It is a mistake, he argued, to abstract patterns that may be observed in society from the context of their 'ensemble' of relations. He reiterated this in at least three examples: vis-à-vis economics, politics, and the concept of the individual as homo oeconomicus. In the case of economic 'laws', for example, “"[d]etermined market" is therefore equivalent to "determined relation of social forces in a determined structure of the productive apparatus", this relationship being guaranteed (that is, rendered permanent) by a determined political, moral and juridical superstructure' (Gramsci, 1991: 410). Thus, economic 'truths' are highly contingent on the social structures in which they are embedded.

The reduction of the understanding of politics to a technocratic, parliamentary politics, and its separation from society (sociology), reflects a similar mistake. Gramsci argues that it is erroneous to believe in the '[c]onviction that the constitutions and parliaments had initiated an epoch of "natural" "evolution", that society had discovered its definitive, because rational, foundations, etc. And lo and behold, society can now be 
studied with the methods of the natural sciences!' (Gramsci, 1991: 244). Gramsci engages in a parallel critique of the 'situatedness' of classical economics' understanding of economic man.

Homo oeconomicus is the abstraction of the needs and of the economic operations of a particular form of society, just as the ensemble of hypotheses put forward by economists in their scientific work is nothing other than the ensemble of p remisses that a re at the b ase of a $p$ articular form of society (Gramsci, 1991: $400 \mathrm{fn} 39$ ).

'Rational, economic man' can only be so in the social and cultural environment that constructs that rationality. ${ }^{12} \mathrm{He}$ turns positivism on itself, arguing that the real question is not the observable 'permanent' forces in society, but rather, how these seemingly immutable patterns are sustained in society.

It is not a question of 'discovering' a metaphysical law of 'determinism', or even establishing a 'general' law of causality. It is a question of bringing out how in historical evolution relatively permanent forces are constituted which operate with a certain regularity and automatism (Gramsci, 1991: 412).

Gramsci's critique of economism and discussions of the 'determined' market, technocratic politics and homo oeconomicus reflect a post-positivist commitment to understanding the ensemble of social relations - manifest structurally, institutionally, and subjectively - as socially constructed.

As with his rejection of determinism, in contrast to 'teleological Marxism', Gramsci's thought does not provide a blueprint for the ideal society. Nonetheless, it provides

${ }^{12}$ Marx also describes the socially 'situatedness' of 'individuals producing in society', c.f. variations through the Grundisse (the outline for A Critique of Political Economy), the original introduction to A Critique of Political Economy (generally included as an appendix), and the Preface to A Critique of Political Economy Karl Marx, $A$ Contribution to the Critique of Political Economy (Marxists.org, 1859 [cited 17 June 2003]); available from http://www.marxists.org/archive/marx/works/1859/critique-poleconomy/index.htm. Yet his discussion centres on the historical trajectory that allows for the (mistaken) abstraction of the individual from society rather than the sociocultural emphasis that Gramsci gives it, which allows for a comparison of political communities, discussed below. 
what Gill calls, 'a rather negative definition, concerning minimum conditions, of the "good society", which he argues 'offers no promises nor prescriptions for the form that such a society might take' (Gill, 1993: 25). Leonardo Paggi offers a similar assessment: 'By concretely articulating the notion of the ethico-political, Gramsci is able to identify, not the content of this new culture, but features of the social and political process which will be its support and form of realisation' (Paggi, 1979: 144). This contingency is reflected in the Prison Notebooks' discussion of the myth of Machiavelli's Prince, which Gramsci critiques as oriented to restoring the past rather than inventing a new future. It assumes a pre-existing (albeit dispersed) collective will, rather than the necessity of forging a new collective will, 'to be directed towards goals which are concrete and rational, but whose concreteness and rationality have not yet been put to the critical test by a real and universally known historical experience' (Gramsci, 1991: 130). A progressive social myth will have goals, but goals that are seen as tentative and conditional rather than concrete. Robert Cox describes it this way:

[the social myth] presupposes a psychic force, a compelling movement combined with a rejection of the prevailing norms (e.g. as hypocritical, demystified). It is a normative force but not a normative plan or set of normative criteria. It can generate movement but not predict outcome. Thus the normative element is crucial but not as teleology (Gill, 1993: 25 quoting a letter from Cox).

Gramsci's critique of economism, positivism, and telos, along with his understanding of political s ubjectivity, p rovide the tools with which to conceptualise a G ramscian perspective on indigenous politics. 


\section{Political subjectivity and indigenous culture}

Gramsci's attention to culture provides the means for thinking about social change in a multicultural context. In Guatemala, where racial-cultural hierarchies of 'traditionalindigenous' / 'modern-ladino' form the basis of disarticulated production in the economy (discussed further in Chapter 3), the relationship between the guerrilla and the indigenous was an issue of ongoing practical and theoretical exploration (Smith, 1990). How should indigenous politics and autonomy be approached, then, particularly if it is acknowledged that indigenous culture in Guatemala has been constructed through a legacy of discriminatory practices over time? From a classical Marxist perspective, the problematic might be the following: if an indigenous culture persists over time because it represents a strategic source of labour, why (on what grounds) should it be protected from assimilation into a more modern, equitable society?

Gramsci's appreciation of the historically and socially contingent nature of knowledge allows him to see rationality, particularly economic rationality, as socially embedded. His rejection of a specific teleology does not require that a progressive society assume a particular form. This open-ended notion of telos and Gramsci's emphasis on the ethico-political character of a social ensemble mean that a particular social arrangement based on a Western understanding of technology need not be seen as inevitable. Nonetheless, there are grounds for cultural assessment and comparison: they are located in the ethos of participatory democracy in all spheres of the ensemble of social relations.

A Gramscian perspective raises the tension of, on one hand, understanding how cultural difference may be constructed (or better: continually reconstructed) within the ensemble of social relations and on the other, recognising the significance of cultural 
difference in terms of p olitical s ubjectivity and the e thics of p olitical a lliances. His discussions of the 'Southern question' in Italy (the uneven development of the South in relation to the North) illustrated a normative perspective on cultural difference, including the need for an autonomous voice for the 'subaltern' in its engagement with more powerful groups (Gramsci, 1978: 451). ${ }^{13}$ A Gramscian position approaches cultural integrity in a way that recognises the relationship between historical material conditions and the construction of identity, yet it also allows for the valuation of subaltern subjectivities beyond class.

\section{Power}

In Gramsci's conception, power is embedded in social practices and reinforced by the material (including ideological) structures of society. His analysis allows us to move beyond overly simplistic notions of power as force to comprehending power as a dynamic embedded in the ensemble of social relations, reinforced by social and cultural practices and understandings of the world. Gramsci moves the notion of power

${ }^{13}$ Gramsci's essay 'Some Aspects of the Southern Question' underscored the necessity of an alliance between Northern workers and Southern peasants for a communist society. He argued that the Southern peasants had been oppressed and exploited 'in yet more odious and bestial ways' than the Northern workers Gramsci, Selections from the Political Writings 1921-1926, 445. Obstacles to a mutual alliance existed on both sides and were the result of bourgeois intellectuals. Northern workers internalized Northern bourgeois attitudes that viewed the South as an impediment to the North and Southerners as biologically inferior Gramsci, Selections from the Political Writings 1921-1926, 444. However, Southern peasants were likewise ill-served by Southern intellectuals (such as Benedetto Croce), whose affiliations lay with national and European society Gramsci, Selections from the Political Writings 1921-1926, 460. The political challenge becomes helping Southern peasants to see their true affiliation should be with Northern workers rather than with the Southern gentry Gramsci, Selections from the Political Writings 1921-1926, 446. Significantly, Gramsci appreciates the need for an autonomous peasant politics and subjectivity: the Turin workers' should not ask for 'guarantees of any kind: neither to the party, nor to a programme, nor to the discipline of the Socialist parliamentary group' but that their Southern collaborators remain answerable to their own constituencies Gramsci, Selections from the Political Writings 1921-1926, 451. 
from institutions such as the state, the conventional 'vessel' of power in Marxist analysis, to ideologies and practices. ${ }^{14}$

To take Steven Lukes discussion of power as a guide, Gramsci's most approximates a three dimensional view of power (Lukes, 1974). In Lukes' schema, a one dimensional view sees only power as expressed through overt conflict. A two dimensional view sees power expressed through both conflict and the ability to set the public (or other relevant) agenda: 'it allows for consideration of the ways in which decisions are prevented from being taken on potential issues over which there is an observable conflict of (subjective) interests...' (Lukes, 1974: 20, emphasis original). The third view of power goes further to look at how power might act to create peoples' understanding of their own interests, and thus might operate beyond the realm of observable conflicts of interest. ${ }^{15}$ Barry Hindess has rightly critiqued Lukes' conception for failing to include the social context of power in his emphasis on maintaining an empirical focus (Hindess, 1976). As Gramsci's conception of power is quite explicitly embedded in the 'ensemble of social relations', it moves beyond Lukes' third dimension. ${ }^{16}$

\footnotetext{
${ }^{14}$ Robert Cox observes that, 'The Machiavellian connection frees the concept of power (and of hegemony as one form of power) from a tie to historically specific social classes and gives it a wider applicability to relations of dominance and subordination ...' R obert W. Cox, ' Gramsci, Hegemony and International Relations: An E ssay in Method', in Gramsci, Historical Materialism and International Relations, ed. Stephen Gill (Cambridge: Cambridge University Press, 1993), 52.

${ }^{15}$ Lukes indeed examines Gramsci in his discussion of the difficulties of working with a three dimensional view of power. Steven Lukes, Power: A Radical View (London: Macmillan, 1974), 47-48.

${ }^{16}$ Nonetheless, Lukes' schema is more useful for drawing out the key dimensions of how Gramsci's conception differs from the mainstream (i.e., in the realm of consciousness), than, for example, Paul Hirst's critique of IR, drawn from Hindess's later work, which does not get to questions of ideology and political subjectivity. Paul Hirst, 'The Eighty Years' Crisis, 1919-1999 -- Power', Review of International Studies 24, no. 5 (1998): 134-5.
} 
Gramsci's account of power is more vigorous and satisfying than definitions of power in mainstream International Relations (IR). As Paul Hirst observes, the dominant understanding of power in International Relations involves a 'capacity-outcome' model, where power is a 'simple quantitative capacity' exercised in a zero-sum game, so 'an actor's capacities can be judged essentially by outcomes - who "has" power is who prevails' (Hirst, 1998: 133-34). He argues that this is not only true of realists, but of their critics as well, who fail in their critiques to offer coherent alternatives (Hirst, 1998: 134)..$^{17}$

In examining the role of US power in international relations, Stephen Gill has observed that, like realists, world systems analysts understand power as 'power over'; he calls the two collectively, 'the conventional wisdom on the American case' (Gill, 2003: 74). The combination of world systems theory and Gramscian analysis, as has been attempted, for example, by William I. Robinson, thus implies significant tensions with the reading of Gramsci offered here. Robinson does not explicitly reconcile the relationship between these two conceptions of power, apparently drawing on world systems theory as a way of redressing what he perceives to be an over-emphasis on intra-core analysis and to the exclusion of core-periphery relations in the 'Italian school' of IR (Robinson, 1996: 30) (Robinson, 1996: 629). ${ }^{18}$ Yet his alternative is to

${ }^{17}$ Hirst charges Robert Keohane with incoherence, and argues that Susan Strange, rather than ending in incoherence, ultimately adopts a conventional definition anyway. Hirst, 'The Eighty Years' Crisis, 1919-1999 -- Power': 134 n6.

${ }^{18}$ Robinson refers to this second article, William I. Robinson, 'Globalization, the World System, and "Democracy Promotion" in U. S. Foreign Policy', Theory and Society 25, no. 5 (1996), in William I. Robinson, Promoting Polyarchy: Globalization, US Intervention, and Hegemony, vol. 48, Cambridge Studies in International Relations (Cambridge: Cambridge University Press, 1996), as a source for the summary of his article, thus both are drawn on for this discussion. His ciritque of the 'Italian School' is 
examine c ore-periphery relations exclusively through the lens of U S foreign policy, which acts as on behalf of 'an emergent transnational elite' in a 'power-over' frame. ${ }^{19}$ The complexity of interactions associated with the ways in which power is exercised and mediated implied by Gramscian analysis thus does not appear in the analysis, in which changes in US foreign policy reflect shifts in the world system rather than elements of agency which might contribute to the construction such an order (Robinson, 1996: 617). Robinson's analysis does provide a helpful reading of the nature of democracy promotion in US foreign policy, including documenting some of the specific strategies used to marginalise popular elements in authoritarian-democratic transitions (which appear to occur in the Guatemalan peace process as well, see Chapter 4). Yet his contribution, rather than being seen as compelling or coherent alternative to the 'Italian school', would best fit under the rubric of an elaboration of 'intellectual and moral leadership' in the reading of Gramsci offered here.

only partially fair, particularly given the limitations of his analysis outlined here: while there is more work for 'Italian School' in theorising the relationships between developing countries and industrialised countries, Robinson makes no mention in Promoting Polyarchy of Robert W. Cox, Production, Power and World Order: Social Forces in the Making of History, 4 vols., vol. 1, Power and Production (New York: Columbia University Press, 1987), which describes several 'peripheral' raisons d'etat as well as the changing nature of 'core' and 'perhiphery' under the internationalisation of production and the state. (The latter, incidentally, is likewise uncited in, but very similar to, Robinson's discussion of globalisation Robinson, Promoting Polyarchy: Globalization, US Intervention, and Hegemony, 31-41.)

${ }^{19}$ This over-emphasis on the US as agent and power as domination has serious consequences for Robinson's empirical work, where he overstates the role, for example, of USAID funded research institutes in Guatemala, which, rather than playing a determining role were subject to a complex process of appropriation and manipulation by local elites William I Robinson, Neoliberalism, the Global Elite, and the Guatemalan Transition: A Critical Macrosocial Analysis', Journal of Interamerican Studies and World Affairs 42, no. 2 (2000). (For a critique of the empirical limitations of Promoting Polyarchy, see: William LeoGrande, 'Deciding to Intervene: The Reagan Doctrine and American Foreign Policy; Promoting Polyarchy: Globalization, US Intervention, and Hegemony', The Journal of Politics 60, no. 1 (1998).) Given Robinson's project is to theorise global Gramscian politics from the perspective of developing countries, it is ironic that his framework marginalises the specific experiences of the (class hierarchies within the) South in constructing such an order. 


\section{Gramscian politics and social change}

Although Gramsci's understanding of power and hegemony appear to operate in a 'totalising' manner, 'a social form "always" has marginal possibilities for further development and organizational improvement' (Gramsci, 1991: 222). Gramsci theorised the nature of social change under such circumstances: of particular significance is the notion of the war of position, the construction of alternative potential hegemonies to challenge a hegemonic order. Nevertheless, Gramsci remained concerned with how dominant groups reassert themselves during moments of social change, his concepts of passive revolution, trasformismo and caesarism illustrate the technologies of power for maintaining control.

As hegemony is exercised through continuous leadership, it may also be challenged and replaced through a war of position. A war of position is the strategy of creating the intellectual and moral leadership component of hegemony before holding the state's coercive power: it is the creation of a viable alternative hegemony in civil society before controlling the institutional 'state'. The war of position reflects the ideologicalcultural battle to be waged, in contrast to the war of manoeuvre, the physical, military battle to control the state of conventional revolutionary politics. Gramsci understood that in the modern political environment the war of position would increasingly replace the war of manoeuvre (Gramsci, 1991: 206-75); (Hall, 1996: 427).

The term 'passive revolution' often appears near the war of position in the Prison Notebooks. It reflects Gramsci's analysis of the failure of progressive forces to overcome conservative interests during Italian unification. Progressives failed for two reasons: an atmosphere of intimidation limited their programme and their leadership 
(Garibaldi) was not sufficiently independent of the intellectual leadership presented by the moderates (Gramsci, 1991: 61). ${ }^{20}$ Passive revolution reflects one response to an organic crisis where significant changes to the economic structure are made from above, 'through the agency of state apparatuses', without the active participation of society more broadly (Simon, 1991: 50). The case for social change is co-opted by the dominant group. In the end, a degree of social change is achieved, but on terms favourable to the dominant group and without the participation of the majority. (Gramsci considered fascism in Italy to be an example of a passive revolution, unlike many Marxists of the day, who considered it the 'last gasp of capitalism'.) This cooptation may manifest itself in various strategies, such as the intellectual leadership inherent in successful hegemony, or the notion of direct co-optation that Gramsci terms trasformismo.

Trasformismo originally described the convergence of left and right parties in Italy after unification, 'until there ceased to be any substantive difference between them' (Gramsci, 1991: $58 \mathrm{fn}$ 6). This reflected a period of bourgeois hegemony in which there was no real opposition or contestation of power (Forgacs, 1988: 430). Gramsci uses the term to describe a process of co-opting potential resistance into the hegemonic regime. He observed two stages of such cooptation in Italian history: first at the individual 'molecular' level, where individual leaders of the opposition join the

20 Gramsci's perspective provides a radical interpretation of the term passive revolution, taken from Vincenzo Cuoco who used the phrase to describe the Neapolitan revolution of 1799 wherein an enlightened bourgeoisie introduced moderate reforms (without popular participation) to pre-empt genuine revolution. Forgacs, ed., A Gramsci Reader: Selected Writings 1916-1935, 413 note 4. Cuoco's conception is echoed in the contemporary democratic transition literature of Guillermo O'Donnell et al., critiqued by Robinson, Promoting Polyarchy: Globalization, US Intervention, and Hegemony . 
dominant bloc, and then at the group level, i.e., the formation of a centre/right nationalist party from ex-anarchists and syndicalists (Gramsci, 1991: $58 \mathrm{fn}$ 6).

When there is a stalemate between forces in society such that 'they balance each other in such a way that a continuation of the conflict can only terminate in their reciprocal destruction', the only solution is for a third force to step in and subjugate the other two (Gramsci, 1991: 219). Gramsci described the solution where 'a great personality' serves as an arbiter of this historico-political situation as Caesarism (Gramsci, 1991: 219). C aesarism m ay be p rogressive or $r$ egressive. What is interesting is Gramsci's critique of caesarism's modern form as a police system: 'It is necessary for the dominant social form to preserve [the] weakness [of the rival progressive force]: this is why it has been asserted that modern Caesarism is more a police than a military system' (Gramsci, 1991: 222).

In his exploration of strategies of promoting or limiting social change, Gramsci articulates different strategies of power and resistance. His discussions elucidate the 'modern form' such strategies take: the increasing significance of the war of position and the emergence of the police over the military.

\section{Historical blocs, the Integral state and world orders}

Gramscian politics operate through subjectivity and knowledge, but are guaranteed by coercion. The relationship between these elements is historically and materially constructed and mediated by the 'ensemble of social relations'. Gramsci's conceptions of the integral state and the historical bloc illuminate the institutionalisation of such 
ensembles, and provide a point of departure for understanding the relationship between political communities at the level of the 'domestic' and the 'international'.

\section{The integral state}

Gramsci's understanding of politics as informed by power operating through historically and materially constructed knowledge and subjectivity is reflected in a broad conception of the state. In his view, the 'state = political society + civil society' (Gramsci, 1991: 262-3). ${ }^{21}$ This amplification of the notion of state reflects Gramsci's observation that at the time of the Russian revolution 'advanced' liberal states were very resilient to revolutionary social change. He argues that in these cases powerful interests did not need to control the state itself to exercise power over society: they could do so through the arena of civil society. Civil society reflects an 'organisational reserve' of the ruling classes. As a result, '[t]he state apparatus is far more resistant than is often possible to believe, and it succeeds, in moments of crisis, in organizing greater forces loyal to the regime than the depth of the crisis might lead one to suppose' (Gramsci, 1978: 409).

For Gramsci, the idea of state includes the social structures of civil society that affect political consciousness: religious institutions, the education system, the press, etc. The state is seen not merely as the monopoly of 'legitimate' force but as an active agent in

${ }^{21}$ For a thorough discussion of potentially competing interpretations of Gramsci's understanding of the state, see Perry Anderson, 'The Antinomies of Antonio Gramsci', New Left Review, no. 100 (1976-7). Nonetheless, Peter Ghosh argues that Gramsci maintained 'a relentless insistence that the only legitimate state is seamlessly bound to, and arises from, society. So what looks like Gramsci's confusion in the usage of terms, his "failure" to find "a single, wholly satisfactory conception of 'civil society' or the State" is really a significant misunderstanding on the part of his classical 1970s commentators'. He goes so far as to argue that Anderson's 'problems and confusions are all self-inflicted' Ghosh, 'Gramscian Hegemony: An Absolutely Historicist Approach': 5. 
socialising the body politic. It is administrative and coercive, as well as educational and formative (Gramsci, 1991: 258-9). Governance occurs through the state narrowly conceived, as well as through the institutions of civil society where the ideological structures of the dominant classes can be constructed and disseminated. It incorporates a combination of direct coercion, socialisation, and the cultivation of consent embodied in the notion of hegemony. ${ }^{22}$

Luis Razeto Migliaro and Pasquale Misuraca suggest that Gramsci's understanding of the state is not 'a fortress to be stormed, as a machine which can be operated differently by various political managements, or as an institutional apparatus which can be the property of a class', but rather 'the organization of relations between leaders and led' (Razeto Migliaro and Misuraca, 1982: 72, 73). Thus for Gramsci, rather than Marx's and Lenin's emphasis on the 'character' of the state (capitalist, socialist, etc.) per se (Razeto Migliaro and Misuraca, 1982: 77), the emphasis is on the 'ensemble of social relations' and its implied strategies of governance.

Gramsci's understanding of civil society has been a matter of great debate among commentators of his work given the number of contexts in which it appears in his work, especially the Prison Notebooks. What is clear is that his definition departs from one understood in terms of "the system of social relations based on the association of people independently of the State and the family which first emerged in Europe in the

${ }^{22}$ Here one might note the difference between this reading of Gramsci and that of Louis A lthusser, who r ejected the n otion of a $\mathrm{n}$ i ndependent civil s ociety a ltogether, arguing that "churches, parties, trade unions, families, schools, newspapers, cultural ventures" in fact all constitute "Ideological State Apparatuses", Louis Althusser, Lenin and Philosophy, and Other Essays (New York: Monthly Review Press, 1971) in Anderson, 'The Antinomies of Antonio Gramsci': 35. Such a position destroys the subtlety of Gramsci's contribution to understanding the relationship between power and knowledge and arbitrarily reifies the state. 
seventeenth century... characterised by "free" labour and a commodity market, a system of law enforcement and voluntary association' (Marxist Internet Archive). Gramsci understands civil society more in terms of a mediating layer between the economic structure and the state ("between the economic structure and the State with its legislation and its coercion stands civil society' (Gramsci, 1991: 208)). His emphasis is less on an inviolable s phere protected from the state than on a cultural milieu that constructs the rationality and homo economicus necessary for production; as Hoare and Newell suggest, 'civil society is in effect equated "the mode of economic behaviour"' (Gramsci, 1991: 209). This understanding thus moves away from a reliance on the direct replication of the European experience to achieve an identifiable 'civil society', as well as from problematic assumptions about a pre-social human nature associated with 'social contract' theorisations of politics (e.g., the civil society of Hobbes and Rousseau (Marxist Internet Archive)). In effect, this conception allows consideration of the ways in which civil society - that is to say a 'private' realm distinct from political society - exists beyond the capitalist core, in much the same way that theorising capitalism itself in the periphery has challenged a broad spectrum of (particularly Marxian) thinkers.

The notion of 'state power' is thus related to the nature of the relationship between the dominant or ruling elements of the 'ensemble of social relations' and the subaltern elements, a question of political subjectivity and legitimacy. This is true both at the domestic and international levels, where power (including its sociological and cultural dimensions) operates both through the political society - institutions of the state or the interstate system (multilateral organisations, etc.) - and through 'civil society' beyond them. 'International relations intertwine with these internal relations of nation-states, creating new, unique and historically concrete combinations. A particular ideology, for 
instance, born in a highly developed country is disseminated in less developed countries, impinging on the local interplay of combinations' (Gramsci, 1991: 182). In this sense, questions of 'state power' posed from the perspective of conventional understandings of the state capture only one site of many where power may operate. The degree to which power operates through 'state power' narrowly understood depends upon whether or not dominant forces in an ensemble of social relations (examined at the domestic or internaitonal level) are hegemonic.

\section{Historical bloc}

The 'historical bloc' provides a means of conceptualising the institutionalisation of the 'ensemble of social relations' at a particular historical moment. It reflects the combination of the Marxian categories of base/structure (the economy) and superstructure (ideology). The historical bloc is 'the complex, contradictory and discordant ensemble of the superstructures is the reflection of the ensemble of the social relations of production' (Gramsci, 1991: 366, emphasis original). This conception is a feature of Gramsci's theory that is considered to distinguish him most from orthodox Marxism (Smart, 1983: 39); (Forgacs, 1988: 424). Yet Gramsci makes this claim precisely by appealing to Marx.

[Marx's propositions tend] to reinforce the conception of historical bloc in which precisely material forces are the content and ideologies are the form, though this distinction between form and content has purely didactic value, since the material forces would be inconceivable historically without form and the ideologies would be individual fancies without the material forces (Gramsci, 1991: 377, emphasis original).

Razeto Migliaro and Misuraca suggest that the difference between Gramsci and (the later) Marx on this matter involves their different understandings of civil society. As Marx reduced civil society to economic relations devoid of mediating institutions of intellectual and moral leadership, he could not distinguish concrete relations between 
base and superstructure, and as a result 'the concrete ways in which the economy and society actually relate to the state escape analysis and subsequently are seen abstractly, by means of speculative concepts, such as determination, correspondence, reflection, conditioning, etc.' (Razeto Migliaro and Misuraca, 1982: 80). Gramsci's conception of civil society, by including the dimension of intellectual and moral leadership, allowed for more specific analysis. ${ }^{23}$ Gramsci's notion of a bloc involves the dimension of political subjectivity, rather than exclusively 'objective' categories of some orthodox Marxisms (Boggs, 1984: 228-9).

The historical bloc reflects the institutionalisation of a particular ensemble of social relations. It is a political formation of a dominant group and the alliances it forms with subaltern and dominated classes: the degree to which these alliances organically construct the world-view of subaltern groups determines whether or not an historical bloc is hegemonic. Thus a historical bloc is a formation of heterogeneous and contingent social elements:

The 'leading elements' in a historic bloc may be only one fraction of the dominant economic class - for example, finance rather than industrial capital; national rather than international capital. Associated with it, within the 'bloc', will be strata of the subaltern and dominated classes, who have been $w$ on o ver b y s pecific concessions and compromises and who form part of the social constellation but in a subordinate role (Hall, 1996: 424).

An historical bloc involves the articulation of a world view to provide 'substance and ideological coherence to its social power' (Rupert, 1993: 81). Yet this world view may or may not be hegemonic: while hegemony always emerges from a historical bloc, not all historical blocs are hegemonic (Adamson, 1980: 177-8). Hegemony reflects a

${ }^{23}$ Razeto Miliaro and Misuraca argue that the root of this discrepancy lies in their two different readings of Hegel. Luis Razeto Migliaro and Pasquale Misuraca, 'The Theory of Modern Bureaucracy', in Approaches to Gramsci, ed. Anne Showstack Sassoon (London: Writers and Readers, 1982), 77. 
condition where a particular order has a 'totalising' effect on the ensemble of social relations, one that particularly is able to govern through consent rather than coercion. Historical blocs may also be 'supremicist', for example, if they remain in power to a greater extent through coercion than consent, i.e., if they are not able to universalise their world view credibly or organically to subaltern groups.

Stephen Gill has compared the Gramscian historical bloc to Foucault's notion of a discursive formation, 'a set of ideas and practices with particular conditions of existence which are more or less institutionalised, but which may be only partially understood by those that they encompass' (Gill, 1995: 403). The stronger analogue in Foucault's work may be the concept of a 'dispositif' or apparatus: 'the system of relations' that can be established between 'a thoroughly heterogeneous ensemble consisting of d iscourses, institutions, a rchitectural forms, r egulatory d ecisions, 1 aws, administrative measures, scientific statements, philosophical, moral and philanthropic propositions' (Foucault, 1980: 194). ${ }^{24}$ Nonetheless, a central difference between the historical bloc and Foucault's concepts, as Gill notes, is that the historical bloc explicitly involves a ttention to the p ower of $\mathrm{c}$ apital a s a s ocial r elation (Gill, 1995 : 404).

\section{Historical blocs, states and the state system}

The historical bloc may be understood at a number of mutually constituting levels: the nation, the region, and the international (Cox, 1993: 259); (Cox, 1987: 6-7). As Robert

\footnotetext{
${ }^{24}$ The notion of a 'dispositif' $h$ as b een u sed to d escribe p ost-WWII c onceptions of 'development' (discussed below). On the compatibility between Gramsci and Foucault, see: Barry Smart, Foucault, Marxism and Critique (London: Routledge \& Kegan Paul, 1983); Anna Marie Smith, Laclau and Mouffe: The Radical Democratic Imaginary (London: Routledge, 1998); Michèle Barrett, The Politics of Truth: From Marx to Foucault (Stanford: Stanford University Press, 1991).
} 
Cox argues, world orders are constructions of and reflections of particular historical blocs. Such an order might be constructed through the explicit agency of a hegemon, as a liberal world order was constructed under British hegemony in the early to mid nineteenth century. Hegemonic orders limit the possibilities for state structures to those consistent with its social structure of accumulation: 'The economic-productive structures of social formations are made compatible with the hegemonic world economy even though state-political structures may differ' (Cox, 1987: 209-10). The liberal world order did not construct the liberal state everywhere, though it exported the functions of the liberal state as widely as possible; in non-European, 'penetrated' regions, new social orders were constructed not on the basis of liberalism in the 'periphery', but on the basis of preserving the basis for the 'core's' 'liberal' production and exchange..$^{25}$

However, as Cox describes in his assessment of the period of rival imperialisms following British imperialism, a particular raison d'etat or set of such logics may emerge in a n on-hegemonic p eriod as well. Thus, the logic of p ower p olitics under industrialisation generates a set of social forces (associated with the concentration of workers and urbanisation) that leads to a particular set of options at the state level, particularly centred around 'the labour problem' (Cox, 1987: 154-7). As with the

${ }^{25}$ As he notes, 'The liberal world order, like the liberal state, posited a separation of politics from economics, together with a fundamental compatibility between them. The free-trading world economy was understood to be the condition for the wealth of nations; this was the domain of industrial, mercantile, and financial operators. The responsibility of the state and the state system was to ensure the conditions for this open world economy while refraining from interfering with the operations of these economic agents. This was the meaning of "liberal" as attached to the terms state or world order. Liberalism had a circumstantial connection with political pluralism and parliamentary government in the British case. Regimes in other countries proved capable of achieving the same balance between economy and politics under authoritarian auspices. Both were "liberal" in the sense discussed here.' Cox, Production, Power and World Order: Social Forces in the Making of History, 127. 
hegemonic, liberal international historical bloc, the non-hegemonic logic of the period of rival imperialisms $(1880$ s - 1919) constructed different kinds of states that nonetheless responded to the imperatives of competitive militarism. ${ }^{26}$

World orders involve the complex interplay between the chaging distribution of military power between states and the potential that productive forces have to change power relations both between and within states (Cox, 1987: 209). The logic of production and the distribution of power in the international system, along with more 'locally' significant social formations influence the structure of both the state (the 'national' ensemble of social relations) and the interstate system (the 'transnational' ensemble of social relations).

\section{World order and the post-WWII historical bloc: development and disarticulation}

There are three periods of interest as world order historical blocs to the study of the Guatemalan peace process: the period from the end of WWII through the economic transformations associated with the early 1970 s, from the early 1970 s through the end of the Cold War, and the period after the end of the Cold War. Within these, the evolving factors of military power and economic order must be analysed, as well as how developments in these spheres interact with prior social relations. In particular,

${ }^{26}$ Cox argues that this era included three phases: the 1870 s -1890 s, when national ambitions challenged liberal hegemony and in forsaking world order, state leaders focused on bridging the chasm of class antagonism to consolidate loyalties to the national order'; the period from then through WWI, when 'the state succeeded through wartime mobilization in reconciling the new [popular] pressures with national unity behind s tate goals'; and finally, 'from 1919 to $1945 \mathrm{c}$ ame a phase of b uilding $\mathrm{n}$ ew historic blocs as the foundations for quite different developmental trajectories with tripartism, state corporatism, and central planning as their principal modes of social relations of production'. Cox, Production, Power and World Order: Social Forces in the Making of History, 164. 
the position of developing countries in these historical blocs and in relations to military and economic issues must be theorised and understood.

The historical bloc to emerge from the end of World War II may be described in terms of an 'embedded liberalism' of the Cold War. 'Embedded liberalism' refers both to the domestic - where macro-economic intervention along Keynsian lines was permitted - and to the international order, which was multilateral in organisation under the auspices of US leadership (Ruggie, 1982: 393). As Stephen Gill puts it, 'This post war settlement among the major interests in the capitalist world corresponded to an internationalization of the basic ideas of the New Deal: it was a negotiated compromise between the various factions of capital and labour in a range of capitalist states' (Gill, 2003: 87). This order applied to industrialised states; countries outside of the economic core were subject to a different logic, as with the liberal order of the 19th century. The US was a leading element in this ensemble as the dominant military and economy of the post-war period and central architect of the Bretton Woods institutions (Ruggie, 1982). It also played a significant role in terms of constructing the 'intellectual and moral leadership' surrounding the nature of post-colonial international capitalist development, i.e., how the project of 'development' in the Third World should be understood, a problematic embued with the politics of Cold War confrontation.

Cox argues that in the post-WWII era, both production and the state were internationalised (Cox, 1987: 244-65). Production was transnationalised as companies in the industrialised countries established dependent relationships with firms in the less industrialised countries for the provision of $\mathrm{r}$ aw $\mathrm{m}$ aterials and labour at lower costs 
than in the 'core' (Cox, 1987: 246-7). ${ }^{27}$ The state was internationalised through 'a process of interstate consensus formation regarding the needs or requirements of [an open] world economy that takes place within a common ideological framework', along with which states themselves are restructured 'so that each can best transform the global consensus into national policy and practice' (Cox, 1987: 254). Such policies are coordinated within a global hierarchy: among the advanced capitalist countries between their own governments (foreign offices, treasuries, central banks) and through multilateral institutions (the IMF, World Bank, OECD) (Cox, 1987: 259).

This order was underwritten vis-à-vis developing countries by power operating on a spectrum from the explicit coercive apparatuses of the Cold War through the less explicit mechanisms of finance and debt through the subtle discipline of normalisation associated with the 'development dispositif'. Direct coercion was exercised predominantly through US military power under the rationale of countering a 'communist threat', though as much scholarship has illustrated and the Guatemalan case supports, this 'threat' was so widely interpreted that in practice interventions were associated with any number of challenges to the social order, including many 'nationalist-capitalist' projects (discussed further in Chapter 3). ${ }^{28}$ US intellectual and moral leadership constructed an understanding of 'development' - modernisation theory - that privileged order and the preservation of particular social relations during

${ }^{27}$ Here core and periphery are general huristic divices and do not refer, for example, to strict categories as in world systems theory. As Cox puts it: "Although the geographical and industrial-sector connotations of core and periphery have become increasingly confused, the analytical validity of the differentiation between core and periphery has been strengthened by the economic crisis since the mid-1970s. The basis for the distinction, however, needs to be redefined so as to avoid tying it too closely to these factors of geography and industrial sector. Cox, Production, Power and World Order: Social Forces in the Making of History, 321.

${ }^{28}$ cf: Robinson, Promoting Polyarchy: Globalization, US Intervention, and Hegemony, 15. 
periods of industrialisation over other principles, leading to understandings of the military as an agent of development and challenges to social relations as security threats (see also Chapter 3). ${ }^{29}$

International financial institutions provided another, symbiotic form of discipline in mediating access to finance and, particularly after the 1970s, structuring and defining development. Nortoiously, the IFIs understood finance as a matter of national sovereignty, lending without discrimination to authoritarian regimes. Further discipline of the internationalised economic order was imposed on developing countries through finance and debt: in exchange for access to finance, developing countries must pursue development that is complementary to the internationalisation of production and 'conducive to accumulation on the world scale' (Cox, 1987: 264). Cox argues: 'international finance is the pre-eminent agency of conformity to [world order] and the principal regulator of the political and productive organization of a ... world economy' (Cox, 1987: 267).

Multilateral institutions also played an important role in 'defining the ideological basis of consensus, the principles and goals within which policies are framed, and the norms of "correct" behavior' (Cox, 1987: 259). The regulatory function of the multilateral agencies has been described in terms of a process of 'normalisation', a practice of establishing rules by which subjects (here Third World states and individuals) must abide; it assesses them vis-à-vis the criteria associated with this rule, creating

${ }^{29}$ cf: David L. Blaney and Naeem Inayatullah, Neo-Modernization? IR and the Inner Life of Modernization Theory', European Journal of International Relations 8, no. 1 (2002); Irene L. Gendzier, Managing Political Change: Social Scientists and the Third World (Boulder: Westview Press, 1985). 
hierarchies, and then establishes the degree of conformity to the rule that must be observed (Brigg, 2002: 427). ${ }^{30}$

The international economy and the $\mathrm{C}$ old $\mathrm{W}$ ar together operated to c onstruct c ertain raisons d'etat in the 'periphery'. Cox describes two kinds of peripheral states to emerge from this period that reflect different levels of incorporation in the world economy: the larger, late-developing neomercantilist developmentalist form of state aims to reproduce the industrialised welfare state in developing conditions. The more marginalised 'protostate' may hold power, but lacks 'either a firm social basis of consent or the administrative capacity to formulate and apply effective economic policies' (Cox, 1987: 218). What needs to be observed and problematised, however, is not just how the international economic order within the hegemonic sphere of the Pax Americana (in Cox's terms) structures states but the ways in which the military dimension of the Cold War mediated such conditions, particularly at the margins of such order, as well. As Robinson has put it, "behind East-West relations ... NorthSouth relations were always intrinsic and central to the whole Cold War Era' (Robinson, 1996: 15).

Under US political and military leadership, the existential threat of 'communism' was used to justify the preservation of certain social relations in the periphery in the face of social transformation. The Cold War security problematic was infused with rivalry around development, classically encapsulated in Nikita Khrushchev's speech of 6

${ }^{30}$ Brigg discusses these practices within a Foucauldian conception of a post-World War II 'development dispositif'. He argues 'the focus on the normalisation of the nation-state does not preclude but in fact relies upon the operation of normalisation at a range of other levels and sites, including that of individual subjects'. Morgan Brigg, 'Post-Development, Foucault and the Colonisation Metaphor', Third World Quarterly 23, no. 3 (2002): 427. 
January 1961 on wars of national liberation, in which he claimed the communist movement would 'bury' the West. At stake for 'embedded liberalism' materially was a particular set of social relations that allowed access to the raw materials and inexpensive labour of the hierarchical world order (Robinson, 1996: 15). Ideologically what was at stake was a 'war of position', waged through the promotion of liberal modernisation theory, towards constructing such an order as hegemonic.

The convergence of these material and ideological forces with particular forms of peripheral economies led to the counterinsurgent state. As discussed further in Chapter 3 , conditions of 'disarticulation', where export production is structured around an exploitative hierarchy understood in terms of social divisions of 'traditional' and 'modern', generate social pressures that present particular challenges to liberal modernisation theory. The reassertion of elite rule under such circumstances has taken the form of counterinsurgency, under US intervention and/or military training and support. The counterinsurgent state is particularly suited to Gramscian analysis, as its repressive apparatus is c ontinually m oving a cross ' public' and 'private' boundaries: 'state' repression and paramilitary death squads operate to the same political ends (also discussed further in Chapter 3).

\section{World order and the financial crises of the 1970s: neoliberalism}

The economic crisis of the advanced industrialised states in the 1970s would transform the post-WWII world order in several ways. The resolution of the crisis would result in a new set of social relations in the North, underwritten through a transnationally constructed project of intellectual and moral leadership. Changes in the structural remit of the $\mathrm{MMF}$ in international finance, the consequences of the debt crisis and the 
purchase of this new intellectual and moral leadership in the IFIs would redefine the understanding of development in this new order.

Inflationary tendencies resulted in a fiscal crisis of the industrialised state and the exchange crisis of the industrialising state (Cox, 1987: 282). As the former's obligations grew, groups within the social compact became divided over the tax burden (Cox, 1987: 281). The resolution of this crisis would have the effect of increasing the power of capital vis-à-vis organised labour in the core countries. However, this crisis was not only 'material' in nature, it also relied upon a project of intellectual and moral leadership that legitimated the challenge to the 'embedded liberal' (at the national level in the core, Keynesian) order, through the elaboration of what may be called neoliberalism. Cox describes this as 'a collective effort of ideological revision undertaken through various unofficial agencies - the Trilateral Commission, the Bilderberg conferences, the Club of Rome, and other less prestigious forums - and then endorsed through more official consensus-making agencies like the OECD' (Cox, 1987: 282). Neoliberalism involves a globalised economy based on the competitive deregulation of capital markets underwritten by certain values and orientations, particularly those of market efficiency and discipline, and established through conditionality, 'quasi-institutional regional arrangements' and multilateral regulatory frameworks such as the WTO (Gill and Law, 1993); (Gill, 1995: 412).

With the move off of the gold standard in the 1970s, multilateral financial institutions changed focus from Europe to the Third World: the IMF became focused on stabilising developing economies with balance of payment problems and the World Bank became the multilateral agency for aid and development. This transition process was not purely 'institutional' in nature, but a 'political' choice to promote the Bretton Woods 
institutions over analogous institutions proposed for the UN system in the context of Southern calls for a 'New International Economic Order' (Bello, 2002: 4). ${ }^{31}$ Furthermore, the remits of the IMF and World Bank would increasingly converge around the logic of structural adjustment programmes: programmes designed to reconstruct debtor countries' ability to repay through liberalisation of exchange rates, trade, export promotion, the elimination of subsidies, balanced budgets and privatisation of public enterprise (Feinberg, 1988). The term 'Washington Consensus' emerged as a way of describing this neoliberal understanding shared by the Bretton Woods institutions, the US government, and other networks of 'intellectual and moral leadership' centred in Washington, DC. ${ }^{32}$

The transformation of world order in response to this crisis results in new raisons d'etat, centred on the acceptance of the world market as 'the ultimate determinant of development' (Cox, 1987: 290). Cox has described the rise of the logic of 'statecapitalism', where the state intervenes to enhance the competitiveness of national industries (Cox, 1987: 290). This rationality governs both industrialised and industrialising nations, and can be found, for example, in works such as Michael Porter's The Competitive Advantage of Nations (Porter, 1990). Competitive advantage

31 The institutional manifestation of this tension was 'resolved' through the 'compromise' of creating a soft-loan capacity at the World Bank in the form of the International Development Association (IDA), and establishing the UN Development Programme (UNDP) for smaller amounts of primarily technical assistance. Walden Bello, 'Prospects for Good Global Governance: A View from the South', (Focus on the Global South, 2002), 4.

32 The term Washington Consensus was coined by John Williamson. Paul Krugman has observed: 'By "Washington" Williamson meant not only the U.S. government, but all those institutions and networks of opinion leaders centred in the world's de facto capital--the International Monetary Fund, World Bank, think tanks, politically sophisticated investment bankers, and worldly finance ministers, all those who meet each other in Washington and collectively define the conventional wisdom of the moment'. Paul Krugman, 'Dutch Tulips and Emerging Markets: Another Bubble Bursts', Foreign Affairs 74 (1995): 28. 
replaces the comparative advantage of classical trade theory under international economic conditions of 'total competition'; the theory posits that the state is not naturally endowed with given factors of production but constructs them, while maintaining the logic of market mechanisms to govern the economy. The discipline of the internaitonal economy in effect is harnessed as a subsidy for capital to create its competitive advantage. (Porter's influence in Guatemala is discussed further in Chapter 4).

Neoliberalism implies a new conception of the state, social relations and political subjectivity. The neoliberal state finds its legitimacy in terms of the promotion of economic growth, redefining the social as a form of the economic. '[T]he economy embraces the entirety of human action to the extent that this is characterized by the allocation of scant resources for competing goals' (Lemke, 2001: 197). ${ }^{33}$ The market becomes the organising principle for both state and society (Lemke, 2001: 200). Government action is both justified and limited by the economy. Its role is to create the conditions assumed by liberalism, i.e., a universal economic rationality, but that neoliberalism recognises to be a social construct: 'government itself becomes a sort of enterprise whose task it is to universalize competition and invent market-shaped systems of action for individuals, groups and institutions' (Lemke, 2001: 197).

\footnotetext{
${ }^{33}$ Thomas Lemke, "The Birth of Bio-Politics': Michel Foucault's Lecture at the Collège de France on Neo-Liberal Governmentality', Economy and Society 30, no. 2 (2001), represents a reconstruction from audio tape of Michel Foucault's exploration of neoliberal governmentality in his 1979 lectures at the Collège de France, which are not available in text form. Discussions of how governmentality relates to Foucault's other work can be found in Colin Gordon, 'Introduction', in Power: Essential Works of Foucault 1954-1984, ed. James D. Faubion (New York: The New Press, 2000) and Arpád Szakolczai, 'From Governmentality to the Genealogy of Subjectivity: On Foucault's Path in the 1980s', (Florence: European Univeristy Institute, 1993).
} 
As Michel Foucault argued, neoliberalism, unlike liberalism, no longer sees economic rationality as a natural characteristic, but one that can rightly be cultivated by the state. 'Whereas in the classical liberal conception, homo economicus forms an external limit and the inviolable core of government action, in the neo-liberal thought of the Chicago School he becomes a behaviouristically manipulable being...' (Lemke, 2001: 200). The individual is subject to the disciplinary features of the universalisation of economic rationality. The person becomes a self-entrepreneur, subject to the responsibility of individual investment decisions involving areas of social services previously under the government's remit: illness, unemployment, poverty, move from being social problems to being individual problems of 'self-care' (Lemke, 2001: 2012).

Neoliberalism, then, explicitly engages the state in constructing the conditions for the market, including the political subjectivity of market rationality. Andrew Barry et al. note of Foucault's description, echoing the central Gramscian problematic: 'The supposed separation of State and civil society is the consequence of a particular problematization of government, not of a withdrawal of government as such' (Barry, et al., 1996: 9). This understanding of neoliberalism differs from those assessments that assume neoliberalism's appeal to the market to arbitrate all social, economic and political questions represents the disappearance of the state. Likewise, it challenges the assumption that neoliberalism lacks any ethico-political rationale beyond privileging capital over labour: in fact, it claims to relocate the social contract away from a coporatist compact among capital and organised labour to the individual.

The move towards neoliberalism creates tensions in the counterinsurgent state. Counterinsurgency poses certain obstacles to the generalisation of neoliberal 
rationality, with its emphasis on efficiency and competitiveness, in the state's economy. The counterinsurgent state's control over the population (discussed further in Chapter 3) represents a considerable expense that economic elites in an economy diversifying away from the traditional sectors of the disarticulated economy may not want to incur. Politically unstable areas that undermine guarantees for capital (the rule of law in economic matters), either through cumbersome traditional legal mechanisms or the graft associated with powerful militaries, inhibit foreign investment and finance.$^{34}$ In addition, counterinsurgency's violent rupture of the 'traditional' social order to secure the threat it poses to 'modernisation' generates conditions that are more favourable to the logics of neoliberalism, particularly the atomisation of collective societies and economies. Thus, the emergence of a neoliberal historical bloc creates conditions that render certain counterinsurgent conflicts 'ripe' for resolution. ${ }^{35}$

\section{Peace processes as technologies of neoliberalism}

Peace processes reflect profound opportunities for restructuring the state. Indeed, this is implied in both academic and multilateral organisations' moves towards an emphasis on addressing the 'root cases of conflict' ${ }^{36}$ To ask how a peace process

${ }^{34}$ Robinson has argued that authoritarian regimes 'are unable to manage the expansive social intercourse associated with the global economy' Robinson, Promoting Polyarchy: Globalization, US Intervention, and Hegemony, 38.

${ }^{35}$ There is no requirement for the neoliberal world order that every economy becomes neoliberal internally, but two factors pressure in that direction: first, the logic of 'total competition' internationally requires a certain number of economies prepared to compete in such vein, through the reduction of labour costs, etc.; second, the intellectual and moral leadership associated with multilateral institutions and the ethico-political premises of neoliberal theory reflect a 'univeralising' impulse.

${ }^{36}$ Cf: Boutros Boutros-Ghali, 'An Agenda for Peace: Preventive Diplomacy, Peacemaking and Peace-keeping', (New York: United Nations, 1992); for a review of the multilateral activities in conflict management and resolution see: Renata Dwan, 'Armed Conflict Prevention, Management and Resolution', in SIPRI Yearbook (London: Oxford University Press, 2001), Renata Dwan, 'Armed Conflict Prevention, 
affects the ensemble of social relations implies two related areas of concern. The first regards the negotiations of the peace process. In principle, negotiations represent the moment of generating consent for a post-conflict order (at least among armed factions, although ideally when emphasising resolving the roots of conflict, in the broader society) ${ }^{37}$ Yet a Gramscian analysis treats such arrangements cautiously, with particular attention to how power operates in such circumstances. Here, of course, power includes several elements: intellectual and moral leadership of powerful groups, the purchase it has in a particular historical bloc, the role of civil society and the political subjectivities emerging from conflict. The second concern relates to the content of the agreements reached through such negotiations. The texts of such agreements reflect blueprints for the post-conflict state and illuminate the ethicopolitical basis for the emergent ensemble of social relations. To the extent that they construct the logic of the dominant world order historical bloc, they work at a very elemental level to realign states and societies.

In the chapters that follow, Gramscian analysis is applied to the Guatemalan peace process. The conflict and its effects on the ensemble of social and economic relations

Management and Resolution', in SIPRI Yearbook (London: Oxford University Press, 2002).

37 One approach to solving 'root causes' that has been gaining currency since the 1970 s is the subfield of conflict resolution, which aims through a neutral third party negotiator to have parties to a conflict identify the psycho-social needs at the root of the conflict and rearticulate them in terms that can be mutually accommodated. Paul Rogers and Oliver Ramsbotham, 'Then and Now: Peace Research -- Past and Future', Political Studies 47 (1999). Yet as Fetherstone and Parkin have observed: 'These approaches attempt to bracket power in practice by assuming improved communication and a re-analysis of the conflict will bring parties together on an equal basis. By not recognising the silent operation of the often huge structural, cultural, social power differences between groups involved in violent conflict ... the coercion has only been hidden'. A. B. Fetherston and A. C. Parkin, 'Transforming Violent Conflict: Contributions from Social Theory', Issues in Peace Research 1997-98 (1997): 25. 
in Guatemala are considered, with attention to the changing features of society during the war. The peace process itself is then examined, with attention to the role of international actors in 'intellectual and moral leadership' and the evolution and techniques of the negotiations themselves. Finally, the construction of the post-conflict state, society and subjectivity in the text of the agreements is explored. The text, which in many circles is broadly considered to be a balance between the IFIs' neoliberal structural adjustment ideal and more progressive Keynesian post-conflict economic theory, is reassessed in terms of a fuller appreciation of the rationalities of neoliberalism. 


\section{The Ensemble of Social Relations in Guatemala}

This chapter examines the ensemble of social relations in Guatemala in the historical context of the civil war and the transition to the peace process. As per the Gramscian analytical framework outlined in Chapter 2, the ensemble of social relations describes the subjective elements of society (groups and identities) and the historically and materially constructed cultural and political arrangements within which they are contained. The ensemble of social relations captures the specific orders and understandings within which power operates in a particular context, given its coercive and consensual (intellectual and subjective) dimensions. Ensembles of social relations are constructed around regimes of production and related to world orders in which they are positioned.

The Guatemalan ensemble of social relations is understood in terms of 'disarticulation', where a number of factors converge to structure society in a highly hierarchical way: production is structured around exploitative labour practices and relies virtually entirely on international markets, which mitigates against the need to engage in 'Fordist' practices associated with role of internal demand in an economy. Exploitative conditions are underwritten by social hierarchies that are historically constructed but continue operate through a historical transition to 'free wage labour' by relegating the costs of social reproduction in non-wage, 'traditional' cultural spheres.

Understanding the nature of disarticulation helps explain the nature and origins of the conflict in Guatemala. The US, as the dominant element in the post-WWII era global order, assumed conditions of disarticulation in its 'liberal modernisation' theories of 
post-war development. It was thus disposed to intervene to support elites in developing countries where disarticulation was under threat, articulating such threats as 'communist' whether or not their internal politics could be rightly characterised as such. Counterinsrugent disarticulation thus reflects a particular raison d'etat constructed in peripheral, export-oriented economies in the post-WWII era of 'embedded liberalism', under what Cox has described as the Pax Americana of US hegemony.

However, disarticulation under liberal modernisation suffers from an internal contradiction: pronounced social hierarchies with no internal markets continually reconstruct a 'traditional' sector of society to sustain social reproduction contra the fundamental basis for modernisation's ethos, the elimination of such a sector in favour of the socially modern. This tension creates the conditions for counterinsurgency: a form of military policing of society that manoeuvres to control the marginalised elements of society as the ensemble of social relations is opened up through elite-led, neoliberal modernisation. Counterinsurgency attempts to reconstruct social identities in a more 'secure' fashion, forging new political subjectivities in the violent excesses of its perception of a generalised the threat to social order.

The contradictions of counterinsurgency, embedded in its own modernising ethos, are also manifest and amplified through military excesses both in coercion and in the economic sphere. Particularly u nder the logic of neoliberalism, the counterinsurgent state becomes too costly for modernising elites as coercive military excesses compromise participation in the international sphere and economic excesses challenge the possibilities for modernised sectors of the economy. The impunity of an 
uncontrolled military compromises safeguards to capital (the rule of law in economic matters) as well as the position of non-military elites in the national economy.

In what follows, this chapter explores Alain de Janvry's conception of disarticulation and outlines the relationship between disarticulation and counterinsurgency. It then examines the origins of the Guatemalan conflict in the challenge to disarticulation and the US-assisted backlash to that challenge. The construction of the counterinsurgent state under such circumstances is described, as is the transformation of powerful economic interests from the 1970 s. The ensemble of social relations entering the peace process reflect these conditions emerging from the contradictions of counterinsurgent disarticulation, a crisis that both implies the opportunity for social change within the peace process and constructs the interests of powerful groups in managing such change.

\section{Disarticulation, counterinsurgency and the ontology of conflict}

Disarticulation describes a condition of peripheral capitalism where a system of functional dualism between the 'modern' and 'traditional' sectors allows wages to be kept below the minimum otherwise required to maintain and reproduce the labour force by having the subsistence economy provide part of people's sustenance. ${ }^{38}$ Social disarticulation relies on a condition of 'semiproletarianisation' in the economy to

${ }^{38}$ Although first expounded by Samir Amin, the discussion here relies on Alain de Janvry's use of the term, which is more oriented to a neo-Marxian approach than Amin's 'development-of-underdevelopment' perspective and therefore, among other virtues, is more compatible with a Gramscian analysis. Samir Amin, Unequal Development (New York: Monthly Review Press, 1976), Alain de Janvry, The Agrarian Question and Reformism in Latin America (Baltimore: Johns Hopkins University Press, 1981), 7-23. 
maintain wages below market value. ${ }^{39}$ As Alain de Janvry explains: 'From the standpoint of the employer, labor is "free" and fully proletarianized; labor is only semiproletarianized since part of the laborers' subsistence needs are derived from production for home consumption' (de Janvry, 1981: 37). Wages are kept below market value because subsistence agricultural production or the informal urban sector subsidise the 'modern capitalist' sector (de Janvry, 1981: 84). ${ }^{40}$ This is possible in disarticulated economies in part because there is no assumption that there will be a home market for the goods produced: maintaining low labor costs in a disarticulated (periphery) economy does not detract from the possibilities for production they way it would in an articulated (centre) economy (de Janvry, 1981:36).

In Latin America, disarticulation is the result of the historical trajectory of labour relations from slavery, to servitude on plantations, to 'free semiproletarians' outside the plantation. As labour becomes more plentiful at each stage, landowners can unencumber themselves of the costs of labour's reproduction. Landowners must pay the full costs of slaves' subsistence, even during periods of sickness, etc. ${ }^{41}$ Servitude on plantations allows landowners to incur only the (fixed) price of the subsistence plot

${ }^{39}$ Disarticulation occurs in two broad types of economies: export-enclave and import substitution. de Janvry, The Agrarian Question and Reformism in Latin America, 32.

${ }^{40}$ Although it originates in export-oriented agricultural production, and thus describes the condition of peasant labour, disarticulation may survive processes of urbanization: 'functional dualism is re-created in other forms in the course of its ultimate elimination. Thus, as the population of Latin America becomes increasingly urban, while employment in the modern sector remains a relatively fixed share of the total labor force, the informal urban sector becomes a new source of subsidy for the maintenance and reproduction of labor power'. de Janvry, The Agrarian Question and Reformism in Latin America, 39-40.

${ }^{41}$ Keeping in mind that 'Only when the supply of slaves is highly elastic and their price is low is overexploitation possible, and it results in early exhaustion through death or incapacitation. But this condition never evolved in Latin America, where slavery consequently assumed relatively paternalistic forms'. de Janvry, The Agrarian Question and Reformism in Latin America, 82. 
and costs of the work performed, while 'free semiproletarians' on land outside of the plantation are less expensive still, involving payment only for work (de Janvry, 1981: 83). Thus, while on the surface or in an 'economic' sense labour relations have become increasingly free, social disarticulation reflects the 'objective' conditions behind the 'subjective forces' that justify repressive labour practices (de Janvry, 1981: 34-5).

The 'semiproletariat' labour market can only exist in certain conditions: when there is surplus labour and when the state controls labour on behalf of private landlords (de Janvry, 1981: 83). ${ }^{42}$ Thus the surplus value generated in disarticulated economies must service multiple claims including the costs of repression to sustain the system: the amount of surplus value that can be generated within a disarticulated economy is dictated by the capacity for social control (de Janvry, 1981: 36-37). Disarticulated economies are thus structured to rely on coercion to maintain export-oriented plantation agriculture. Force is a long-standing feature of labour relations in such settings, yet one that is maintained in the transition to the capitalist labour 'market' in the periphery, recalling Stuart Hall's attention to the differential incorporation of 'actually existing capitalism'. ${ }^{43}$ Such practices are underwritten with the 'subjective' understandings of different social groups associated with different roles, 'traditional' and 'modern'.

\footnotetext{
${ }^{42}$ Peasants may nonetheless participate to a certain extent 'freely' in the disarticulated economy because they opt to maintain some control of their economic lives: 'Whereas the fully proletarianized worker loses both control of the production process and ownership of the means of production, the semiproletarianized worker maintains these two forms of control. Because semiproletarians seek to protect this control, they compete fiercely on the labor market and accept wages below the price of subsistence'. de Janvry, The Agrarian Question and Reformism in Latin America, 84.

${ }^{43}$ As per the discussion in Chapter 2, Stuart Hall, 'Gramsci's Relevance for the Study of Race and Ethnicity', in Stuart Hall: Critical Dialogues in Cultural Studies, ed. David Morley and Kuan-Hsing Chen (London: Routledge, 1996), 437.
} 
Furthermore, disarticulated economies inherently depend on external relationships for financing and markets (de Janvry, 1981: 40), and although not explicitly discussed in de Janvry's work, for smaller economies, military assistance as well. The reproduction of the ensemble of social relations implies a dynamic between domestic and international involving material and subjective elements.

\section{Disarticulation and counterinsurgency}

Disarticulation r eflects the mutual construction of the traditional and the modern in peripheral capitalism: a dynamic that reconstructs the peasantry as economically and socially subordinate through state coercion acting for private interests with the assumption of free labour. This system generates certain tensions and contradictions: between the labour 'market' and the objective bases for repression, between the assumption of the modern and the (re)production of the traditional and, indeed, related assumptions of the universality of (a particular) modern subjectivity and the construction of the subordinated other. When such tensions appear to destabilise the ensemble of relations in a disarticulated society, one response historically has been counterinsurgency.

\section{Counterinsurgency: from colonisation to modernisation}

Military historian Ian F. W. Beckett defines counterinsurgency in terms of the awareness of the need for political action to complement military action in combating irregular a rmies (Beckett, 2001: c hapter 2). Thus, a lthough insurgencies d ate to the fifteenth century $\mathrm{BC}$, the notion of counterinsurgency only enters French military doctrine around 1850 with its experiences in West and Central Africa and British military doctrine circa 1896, with the War Office's publication of Small Wars: Their 
Principles and Practice, 'based on a wealth of colonial experience over the past century' (Beckett, 2001: 32). Theorists often attempt to understand counterinsurgency thinly, as an apolitical set of military strategies and techniques, ${ }^{44}$ yet given the overtly political element of counterinsurgency as well as the specific circumstances with which it is consistently related, to do so commits the same errors discussed in Gramsci's critique of positivism (see Chapter 2).

The principle sources for the development of counterinsurgency theories are the French colonial experience, the British colonial experience, and the US experience with counterinsurgency in the 20th century (Beckett, 2001: chapter 2), all cases distinguished by the 'subjective' social hierarchies associated with disarticulation. These examples are characterised by pronounced social hierarchies associated with significant dislocation for the sake of modernisation. Such a pattern is familiar to students of colonisation; the US has supported elite-led governments in the Third World, understanding that they were better suited to the difficult task of modernisation ("the masses were "naturally indifferent to political matters" (Shafer, 1988: 84), quoting US National Security Council Document 51). Indeed, US counterinsurgency theorists have understood colonisation as part of the modernisation process they seek to promote.

The US understanding of counterinsurgency is intimately related to the dominant understanding of modernisation in the 1950s and 1960s, exemplified by Walt W.

44 Cf: Douglas S. Blaufarb, The Counterinsurgency Era: US Doctrine and Performanmce, 1950 to the Present (New York: The Free Press, 1977); John J. McCuen, The Art of Counter-Revolutionary War: The Strategy of Counter-Insurgency (Harrisburg, PA: Stackpole Books, 1966). Indeed, to an extent Beckett is guilty of this as well, despite his own definition, as he understands politics, like military strategy, to be a technical realm. 
Rostow's The Stages of Economic Growth: A Non-Communist Manifesto. Rostow, who was Kennedy's deputy national security advisor and an architect of its counterinsurgency policies, understood colonisation as a necessary (and seemingly benign) precursor to modernisation:

Colonies were often established initially not to execute a major objective of national policy, nor even to exclude a rival economic power, but to fill a vacuum; that is, to organize a traditional society incapable of selforganization (or unwilling to organize itself) for modern import and export activity (Rostow, 1990: 109).

This understanding of economic modernisation was paired with the theorisation of political development to justify the necessity elite-led rule (Shafer, 1988: chapter 3).

In their characterisation of the e lite / $\mathrm{m}$ ass division $\mathrm{p}$ arallel to that of the modern / traditional, in effect theories of counterinsurgency assume a kind of social disarticulation, which they must protect from insurgency. These assumptions about the nature of society are obscured by counterinsurgency's claim to being an apolitical military technology, whose applicability is, if not universal, dictated by logistical, military considerations (Blaufarb, 1977: 289-91). From a Gramscian perspective, the counterinsurgent project amounts to a highly militarised 'passive' revolution infused with colonial anxieties of race and development.

\section{Counterinsurgency's threat: the anxieties of disarticulation}

Counterinsurgency's remit involves securing a particular social order under threat (Shafer, 1988: 63, 155-6);(Castro and Ettenger, 1994: 67), it must therefore navigate the contradictions that give rise to conflict while maintaining to some extent the premises of that order. The question of the maintenance of social order within the hierarchical ensemble of social relations means that control of the population and its identity, rather than the conventional military question of territory, becomes central to 
the counterinsurgency project. The maintenance of social order becomes rooted in the control of the population (Blaufarb, 1977: 288); (McCuen, 1966: 98); (Stepputat, 1999: 57). Initially this may be understood as an extensive policing operation (Stubbs, 1989: 247), however, when it escalates, the emphasis on controlling the population leads to imperative that there is no neutral position and that identity itself must be secured (Stepputat, 1999: 66); (McClintock, 1985: 258).

To m aintain the v alidity of h ierarchical s ocial o rder, counterinsurgency understands the $\mathrm{n}$ ature of the threat to stability in terms that $\mathrm{r}$ econfirm the s ubordination of the identities to be secured, the peasantry, the 'natives' or the indigenous. It attributes instability not to objective conditions of exploitation, but to the vulnerability of engaging in 'modernisation' and outside agents who manipulate the marginalised. Thus, the peasantry is constructed as passive and apolitical (Shafer, 1988: 106), Indians are understood as 'very susceptible ... easy to ply, just like clay' (Stepputat, 1999: 71), native peoples are seen as easily indoctrinated (McCuen, 1966: 98). Instability a rises when external agents of subversion - communists or nationalists manipulate the naïve subalterns of the disarticulated ensemble of social relations, a scenario that becomes more likely under the inherently destabilising (yet inevitable) process of modernisation (Shafer, 1988: 106, 50). US counterinsurgency theories link the threat of insurgency to a global ensemble of social relations characterised by Cold War rivalry, in which communism represents a s inister perversion of modernisation that exploits the fragility of countries in the process of development. ${ }^{45}$ Furthermore, as

45 This perception was in large part fuelled by Nikita Khrushchev's speech on wars of national liberation of 6 January 1961, in which he claimed the communist movement would 'bury' the West. Charles Macehling Jr., 'Counterinsurgency: The First Ordeal by Fire', in Low-Intensity Warfare: Counterinsurgency, Proinsurgency and Antiterrorism in the Eighties, ed. Michael Klare and Peter Kornbluh (New York: 
Gerald Horne has illustrated, the US emphasis on anticommunism was often an extension of notions of white racial supremacy that were acceptable at the beginning of the 20th century (Horne, 1999). ${ }^{46}$

The contradictions of securing and subordinating the subaltern's identity are expressed 'tactically' through a movement between the polls of consent and coercion, which in the disarticulated context are pathologically expressed in terms of 'hearts and minds' campaigns, on the one hand, and the absolute identification of the subaltern with the threat on the other (genocide in its extreme manifestation, as occurred in Guatemala). 'Hearts and minds' campaigns represent the military ideal for the simple resolution of the political dimension of counterinsurgency. Yet they always reiterate their primary objective of social control through tactics such as reorganising the rural population into strategic hamlets, designed ostensibly to provide some social services but primarily to isolate the peasantry from the guerrilla (Stubbs, 1989: 250) (Sharckman,

Pantheon Books, 1988), 22; Blaufarb, The Counterinsurgency Era: US Doctrine and Performanmce, 1950 to the Present, 18. Yet even relatively 'moderate' positions in such circles drew similar conclusions from Mao Tse-tung's success in China. Douglas S. Blaufarb, formerly affiliated with the CIA and the RAND corporation, a major think tank of counterinsurgency theory, reflects that communist successes in 'backwards' regions: 'suggested that something surreptitious was afoot, a worldwide campaign to make major changes in the power balance masquerading as something else. Further study confirmed that, indeed, a sophisticated method was being employed, and from that fact it was not a large step to conclude that the world was witnessing a concerted and clever effort to revise the balance among the major powers by stealth and deception'. Blaufarb, The Counterinsurgency Era: US Doctrine and Performanmce, 1950 to the Present, 2.

${ }^{46}$ For a discussion on the 'norm against noticing' race in the discipline of International Relations, see: Robert Vitalis, 'The Graceful and Generous Liberal Gesture: Making Racism Invisible in American International Relations', Millennium 29, no. 2 (2000). See also: R. J. Vincent, 'Race in International Relations', International Affairs 58, no. 4 (1982); Roxanne Lynn Doty, 'The Bounds of 'Race' in International Relations', Millennium: Journal of International Studies 22, no. 3 (1993). 
1974: 198); (Shafer, 1988: 116-7). ${ }^{47}$ If the guerrilla cannot be exorcised from the peasantry through such 'consensual' arrangements as winning their hearts and minds, the entire peasantry becomes suspect, 'infected' with subversion and thus inherently the enemy to be eliminated (McClintock, 1985: 258).

As with the obscured but necessary relationship between state coercion and private production in disarticulated economies, counterinsurgency also operates by shifting the boundary between public and private. This reflects the tensions between the role of the state in defending elite privilege and the necessity of defending the legitimacy of such order through appeals to society more broadly understood. Thus,

On the one hand, the private sphere becomes vulnerable to sudden, brutal and arbitrary intrusions on the part of authorities. On the other hand, the authorities cease to operate in a true public fashion. Punishment becomes secretive, unavowed, in what amounts to the privatization of state coercion (Yashar, 1997: 242). ${ }^{48}$

The military becomes the paramilitary and warfare becomes covert and extra-legal (McClintock, 1985: 272). Death squads occupy the boundary between public and private, for example, in the use of off-duty military and police personnel in privately organised activities. This blurring of the distinction allows for the maintenance of the dominant group's understanding of social order without requiring that it be exposed to broader scrutiny. The division of competencies such that the military becomes an

${ }^{47}$ Indeed, the case for the necessity of this political dimension and winning 'hearts and minds' is often put forward contra the 'conventional' military position that such strategies as too ambitious or even potentially counterproductive if insurgents take such aid for their own cause. Blaufarb, The Counterinsurgency Era: US Doctrine and Performanmce, 1950 to the Present, 289; D. Michael Shafer, Deadly Paradigms: The Failure of US Counterinsurgency Policy (Princeton: Princeton University Press, 1988), 118-23. To reiterate, however, this understanding of the political is hierarchical and disarticulated.

${ }^{48}$ While largely sympathetic to this observation, it is important to note that in the argument being made here, state coercion already works for private interests; counterinsurgency represents a particular amplification of that logic. 
autonomous institution of government allows for violence to be reified as a purely military operation with its own logic divorced from the ensemble of social relations, while in fact it precisely operates as the guarantor of a particular, elite-defined order.

Counterinsurgency's aim is to secure a disarticulated ensemble of social relations during moments of social change, which, although gone awry, at their root are understood to reflect the constructive process of modernisation. On one level, this implies the construction of new subjectivities to mitigate the 'traditional' subaltern's lack of identification with such a process. However, the nature of counterinsurgent violence, tied so intimately to understandings of identity, also traumatises in ways that have macro-subjective effects.

In what follows, the historical construction of disarticulation in the Guatemalan ensemble of social relations is explored. This is a social hierarchy based significantly on $\mathrm{race}$, in which $\mathrm{racial} \mathrm{c}$ ategories are reconstructed through the disarticulation and coercion associated with plantation agriculture. The contradictions generated in this process lead to a popular reaction and a decade of reform, whose project of smaller scale capitalist agriculture could not overcome the power institutionalised in the disarticulated ensemble of social relations. Securing the process of modernizing and reconstructing the ensemble in the post-reform era inaugurates the counterinsurgent state.

\section{Disarticulation in Guatemala: race, force, and economy}

The relationship between race, force and the economic mode of production in Guatemala reflect 'common sense' understandings of racial hierarchies and their 
relationship to e conomic production and the (legitimate) $\mathrm{u}$ se of force that a re longstanding features of colonial and independent state. ${ }^{49}$ These relationships are continuously reconstructed, particularly with the generalisation of coffee cultivation. Yet the expansion of commercial agriculture is a lso to an extent constrained by the strength of indigenous resistance to ladino oppression, a dynamic related to elite political debates. This historical dynamic illuminates significant tensions within ('actually existing') liberalism, where conditions of such 'exceptionalness' justify the resort to violence and anticipate the counterinsurgent state. ${ }^{50}$

The racial hierarchy in Guatemala precedes the independent state. A racial hierarchy was established through the conquest and was reflected in intellectual debates, for example, about whether Indians possessed souls. Such theological questions, however, were intimately related to the political-economic arrangements of the plantation system; indigenous 'idleness' was both an economic and an ethical question: forced labour was considered a moral necessity (MacLachlan, 1988: 48). The indigenous view of land and labour as a single unit was likewise considered problematic and force was philosophically and theologically defended an acceptable measure to institutionalise the concept of private property (MacLachlan, 1988: 48).

\footnotetext{
${ }^{49}$ For histories of Guatemala, see: James Dunkerley, Power in the Isthmus: A Political History of Modern Central America (London: Verso, 1988); Jim Handy, Gift of the Devil: A History of Guatemala (Toronto: Between the Lines, 1984); Paul J. Dosal, Power in Transition: The Rise of Guatemala's Industrial Oligarchy, 1871-1994 (Westport, CT: Praeger, 1995); Carol A. Smith, ed., Guatemalan Indians and the State, 1540 to 1988 (Austin: University of Texas Press, 1990); Charles D. Brockett, Land, Power and Poverty: Agrarian Transformation and Political Conflict in Central America, ed. Gilbert W. Merkx, Thematic Studies in Latin America (Boston: Unwin Hyman, 1988). For political-economic histories, see: Victor Bulmer-Thomas, The Political Economy of Central America since 1920 (Cambridge: Cambridge University Press, 1987); Edelberto Torres-Rivas, History and Society in Central America, trans. Douglass Sullivan-González (Austin: University of Texas Press, 1993); David McCreery, Rural Guatemala 1760-1940 (Stanford: Stanford University Press, 1994).

${ }^{50}$ For a brief timeline of Guatemala's political history, see Appendix 1.
} 
Elite political debates in Central America at independence (1821) were polarised between Liberals and Conservatives. ${ }^{51}$ Liberals favoured free-trade, the expansion of commercial agriculture, and sought to constrain the power of the Catholic Church; Conservatives sought 'a return to the past', supporting the Church and the 'customs of colonial society' rather than the further commercialisation of agriculture and increased trade, which invited greater foreign influence in Guatemala (Cambranes, 1985: 34). The first Liberal regime (1831-37) sought to modernise the state and eliminate both indigenous and Hispanic traditions. This involved abolishing the privileges of the church, establishing independent education and a new legal code (Woodward Jr., 1990: 60). The Liberal programme also involved attempts to privatise and systematise land tenure, which threatened indigenous communal property (Weaver, 1999: 136). ${ }^{52} \mathrm{~A}$ peasant revolt in 1837 , which brought a conservative government to power, reflected the indigenous objection to the erosion of traditional land tenure in the countryside. The fear of such backlashes in Guatemala (where the indigenous population was much stronger and more numerous than in other parts of the Isthmus) would condition the relationship between criollo (white creoles), ladinos and indigenous in the future. ${ }^{53} \mathrm{~A}$

51 These debates were initially embedded in the larger question of whether the Central America would remain a single republic or be divided into smaller countries. Guatemala came into fully independent statehood in 1839, after the break up of the United Provinces of Central America. See: Dunkerley, Power in the Isthmus: A Political History of Modern Central America, 5-20 and Robert G. Williams, States and Social Evolution: Coffee and the Rise of National Governments in Central America (Chapel Hill: University of North Carolina Press, 1994), Chapter 6.

52 See also: Wayne M. Clegern, Origins of Liberal Dictatorship in Central America: Guatemala, 1865-1873 (Niwot, CO: University Press of Colorado, 1994).

${ }^{53}$ Dunkerley notes that the indigenous element of the rebellion, 'took the shape of an aggressive social mobilization that cowed even its clerical and Conservative sponsors'. But he argues, 'This should not be viewed solely as a response to provocative Liberal measures that lacked social backing or even to the coincidental outbreak of cholera in 1837 , which ravaged the population of the highlands and compounded superstitions ... Priests certainly played on this anguish and laid responsibility for the calamities upon 
second Liberal regime, particularly associated with the expansion of coffee cultivation, came to power in 1871 . The infrastructural requirements for coffee exceeded those for previous agricultural commodities, and thus demanded the active involvement the state to assist in the promotion of exports, a remit that the Conservatives failed to address but that the Liberals were willing to take on (McCreery, 1994: 13); (Williams, 1994: 207-8).

Non-subsistence production in Guatemala has been based on agricultural products grown in plantation conditions for export: first concineal, followed by indigo, then coffee and sugar cane, to which were added bananas, cotton, and cardamom in the 20th century. ${ }^{54}$ Coffee, however, was the first product that could be cultivated throughout the country, and is thus associated with the expansion of the plantation economy from the 1860s (Smith, 1990). Coffee cultivation only required large numbers of workers for 4-6 months of the year; this and the experience the peasant revolt in 1837 , promoted the protection of indigenous communities as 'labour reserves' for seasonal agriculture (McCreery, 1986: 104). Indigenous communities 'could be allowed and even encouraged to survive ... to reproduce and train an agricultural workforce and sustain these individuals in the off-season or when they became too ill or old for productive use in the export sector. Resources were manipulated so that villages had

the sin of Liberalism, yet their agency was but one figure in the resistance of communities that had to some appreciable degree recovered from both the initial demographic collapse of the Conquest and the disruptive, centrifugal dynamics of labour on indigo plantations, which had been in decline in Guatemala itself for several decades'. Dunkerley, Power in the Isthmus: A Political History of Modern Central America, 13.

${ }^{54}$ A comprehensive description can be found in Julio Castellanos Cambranes, Coffee and Peasants: The Origins of the Modern Plantation Economy in Guatemala, 18531897 (Stockholm: Institute of Latin American Studies, 1985), chapter 1. Concineal was a natural dye made from the concineal insect, replaced by synthetic alternatives in European markets by the 1860 s. 
the minimum land necessary, "depending on the size of the community" (McCreery, 1986: 104).

Both conservatives and liberals supported various coercive labour practices against the indigenous. F orced labour antedated the independent state, but became mediated by the agricultural fortunes and political debates in the post-independence state. ${ }^{55}$ Given the sense of labour shortages associated with the expansion of coffee, the liberal government reintroduced the colonial forced labour requirement, the mandamiento, in 1876 (McCreery, 1986: 103-5). That such measures clearly conflicted with liberal principles of free labour went largely unacknowledged.

The government was rarely willing even to acknowledge the existence of mandamientos and insisted instead that the indigenous population enjoyed the "precious guarantees of the constitution", which included freedom of contract. Indians, however, found themselves sent repeatedly against their will to the coast. Such hypocrisy initially confused even a few local officials: "It seems that Item 3 of your recent note calls for issuing mandamientos". They quickly caught on, however, and each year dispatched thousand of mozos from the highland coffee estates (McCreery, 1986: 107). ${ }^{56}$

Mandamiento was constructed by the state for the benefit of the private sector. One way of being exempted from the mandamiento was to already be in debt peonage to a

55 The following relies heavily on the work of David McCreery, perhaps the preeminent scholar of Guatemalan labour history, as do many of the more general studies noted in this chapter. See, inter alia: David McCreery, 'Coffee and Class: the Structure of Development in Liberal Guatemala', Hispanic American Historical Review 56, no. 3 (1976); David McCreery, "An Odious Feudalism': Mandamiento Labor and Commercial Agriculture in Guatemala, 1858-1920', Latin American Perspectives 13, no. 1 (1986); McCreery, Rural Guatemala 1760-1940 ; David McCreery, 'Wage Labor, Free Labor, and Vagrancy Laws: The Transition to Capitalism in Guatemala, 1920-1945', in Coffee, Society, and Power in Latin America, ed. William Roseberry, Lowell Gudmundson, and Mario Samper Kutschbach (Baltimore: Johns Hopkins University Press, 1995).

56 The paragraph concludes by noting: 'Not surprisingly, the Indians protested these abuses: "Under Liberal laws which guarantee our rights, we believe that no one may be forced to work against his will and that all coercion of this sort is illegal". Such complaints met with little response'. McCreery, "An Odious Feudalism': Mandamiento Labor and Commercial Agriculture in Guatemala, 1858-1920': 108. 
private finca. Nonetheless, the forced labour system drove wages down for debt peons and 'free' labour and accelerated class differences in traditional communities (McCreery, 1986: 111-2). The move to coffee decreased the productivity in traditional highland communities as well (McCreery, 1986: 112).

Debt peonage gave way to vagrancy laws that essentially paralleled the coercive structure of the debt arrangements: they were constructed to compel the poor to work. Thus, in additional to 'conventional' definitions, the Guatemalan law defined vagrancy in terms of how much land one possessed and cultivated (McCreery, 1995: 220); (Cambranes, 1985: Chapter 8); (Dunkerley, 1988: 25-42). Like debt peonage, the vagrancy laws accelerated the socio-economic-differentiational effects in traditional communities (McCreery, 1995: 220-3). These similarities resulted from the persistent question from the elite perspective: how to generate the pressure to compel Indians to participate in an economy they rejected, particularly under (at least perceived) conditions of renewed resistance from the 1920 s (McCreery, 1995: 213). ${ }^{57}$ Thus 'free labour' nonetheless required coercion because 'the Indian lacked the "civilized needs" that would drive him into the wage labor market' (McCreery, 1995: 211-2). The inapplicability of liberal assumptions about market forces to the Indian population (which 'responded to the opportunity to make higher wages but not to that of simply making more money'), led to two conclusions: either the reduction of its prominence in Guatemalan society through its elimination or dilution (via 'the immigration of “healthy elements"') or its rehabilitation towards 'economic rationality' (McCreery, 1995: 212).

${ }^{57}$ See also: McCreery, Rural Guatemala 1760-1940, chapter 10. 
Carol Smith relates the evolution of race in Guatemala to the generalisation of coffee cultivation. According to Smith, the term ladino - which today refers to the nonIndian/Latin population - originally referred to Indians who had lost their cultural ties to the indigenous lifestyle. ${ }^{58}$ The introduction of coffee as a cash crop created (what is today) the racial distinction: ladinos became managerial agents for the white elite and transformed culturally and economically to be more 'modern'. As a result, they were perceived to be less indigenous. Smith argues that race was more compelling than class difference because those of the same class (smallholding peasants) but of different 'ethnicities' w ere s patially s eparated. ${ }^{59}$ 'Ladinos (who at this point in time were presumed to have some white blood) filled the newly created class positions because, as "partial" whites, they did not challenge traditional ideology of race hierarchy in taking the mediating role as agents between plantation owners and workers' (Smith, 1990: 85). The exploitative power behind the racial hierarchy meant that 'ladinos' participated in this arrangement, 'not only because some of them benefited from the exploitation of Indians but because all of them benefited from being treated as non-Indians' (Smith, 1990: 90).

Race hierarchy and the modernisation project of the liberals were explicitly connected:

Progressive Guatemalans, wanting to both "enlighten" and "whiten" their nation, attempted a vast overhaul of national institutions in imitation of Western models. They also attempted to encourage European migration in order to improve the local racial stock. While Guatemalan progressives blamed S panish c olonialism for Guatemala's b ackwardness, they $h$ ad no program for development other than a dependent, imitative one. As they

\footnotetext{
${ }^{58}$ Smith reminds us that the signifiers that distinguish Indians from non-Indians today (religion, dress, political forms) 'are not surviving pre-Hispanic forms but a fusion of native and Spanish traditions'. Carol A. Smith, 'Origins of the National Question in Guatemala: A Hypothesis', in Guatemalan Indians and the State, 1540 to 1988, ed. Carol A. Smith (Austin: University of Texas Press, 1990), 74.

${ }^{59}$ Maps of Guatemalan economic regions, insurgent regions and political departments can be found in Appendix 2.
} 
saw it, development required all of Guatemala to become as Europeanized (and, they hoped, as white) as the Creole elite (Smith, 1990: 76).

The period of liberalism associated with this move to coffee cultivation is marked both by the 'racialisation' of class divisions along cultural lines and by the involvement of foreign investment in the economy. Coffee production particularly attracted foreign immigration in the 1880 s and 1890s; such farmers 'got away with a highhanded manner in part because Liberal ideology presumed the inherent superiority of immigrants from the more developed countries' (McCreery, 1994: 233). Germans were the largest and most prominent group of expatriate farmers, however, the presence of foreign investment in the economy was more widely spread, involving French and US ownership of transport facilities and British and German control of marketing channels (Smith, 1990: 83-84). By the 1930s, foreign interests owned all six of the largest coffee companies in Guatemala (McCreery, 1994: 234). McCreery provides data on the composition of the sector by 1938-39:

\begin{tabular}{|c|c|c|}
\hline \multicolumn{3}{|c|}{ Guatemalan Coffee Exports by Nationality of Exporter, 1938-39 } \\
\hline Nationality & Exports (quintales) & Value (quetzals) \\
\hline German & 497,549 & Q4,974,719 \\
\hline Dutch & 218,975 & $2,214,590$ \\
\hline U.S. & 210,921 & $2,083,194$ \\
\hline Guatemalan & 67,474 & 696,924 \\
\hline Spanish & 12,025 & 115,122 \\
\hline English & 9,100 & 86,718 \\
\hline Total & $1,016,044$ & Q10,171,267 \\
\hline
\end{tabular}

Source: (McCreery, 1994: 234)

The racialised categories associated with the expansion of coffee in Guatemala were reinforced by international capital which, through its knowledge of civil engineering and access to the European markets, was able to reiterate the 'superiority' of Europeans and whites.

Liberalism in this context took a particular form in as much as it attempted to replicate formally, culturally, and racially, the industrialised countries taken as models. This 
required a particular intervention by the government that Frederick Stirton Weaver has aptly observed is quite similar to the tenets of modernisation theory. He notes,

Such vigorous, interventionist state policies might seem inconsistent with the discourse of nineteenth-century liberalism, but Guatemala Liberals recognized the logic of the analysis: the scale of needed change was so great that it required an agent independent of current social forces ... This meant that a technocratic and a uthoritarian s tate, supposedly $n$ eutral and above politics, was necessary and appropriate to produce a more open, free, and prosperous Guatemala (Weaver, 1999: 136).

The resolution of development and liberalism as understood in Guatemala and later the United States thus invokes the use of 'neutral, technocratic and authoritarian' techniques of g overnment, which require military g uarantees. 'The c ongruence with North American modernization theory - with Huntington (1968) as the classic statement - is once again impressive' (Weaver, 1999: 136).

As significant as foreign investment in coffee was the foreign investment in bananas, which was controlled by the US-based United Fruit Company (UFCO). ${ }^{60}$ The most controversial aspect of the UFCO's o perations in Guatemala involves the degree to which its expansion was associated with the construction of the commercial transportation infrastructure and thus the control it was able to exert over the economy more broadly, earning it the moniker 'El Pulpo' (the Octopus). The company controlled the railways, ports and telegraph system in Guatemala and dominated most of the shipping that its agricultural exports relied upon.

${ }^{60}$ For a pithy description of the banana sector as a vertical (and externally-oriented) enclave, see Torres-Rivas, History and Society in Central America, 30-41. For a more detailed discussions of its expansion via control of transport, see Charles David Kepner, The Banana Empire: A Case Study of Economic Imperialism (New York: Russell and Russell, 1967); Paul J. Dosal, Doing Business with the Dictators: A Political History of United Fruit in Guatemala 1899-1944 (Wilmington, DE: Scholarly Resources, 1993). 
The UFCO's expansion occurred under the dictatorship of President General Jorge Ubico Casteñada (1931-1944) and the economic crisis of the 1930s. Paul Dosal has argued that the establishment and expansion of the UFCO in Guatemala could only take place during dictatorial regimes (Cabrera, then Ubico), because other elites would have vetoed the concessions the company received had they been subject to parliamentary approval (Dosal, 1993: 38). Others have suggested that such strong tactics were required by the potentially explosive economic conditions of the day (Cullather, 1999: 9), and the difficulties of attracting capital to Central America in such conditions created the economic imperative to provide generous investment terms (Grieb, 1979: 186). ${ }^{61}$

There are indeed apparent tensions and contradictions of Ubico's tenure. He allowed for the UFCO to establish its stranglehold on key sectors of the Guatemalan economy, though he also established an advisory council for modernising elites to create a national industrial policy. ${ }^{62} \mathrm{He}$ was a member of the oligarchy, albeit a modernising one, as well as the military, to which he gave control of the labour supply with the transition from debt peonage to vagrancy laws. ${ }^{63}$ His oppressive measures alienated the

${ }^{61}$ Ubico came to office when Guatemala had accrued a US\$5 million debt, the interest on which threatened to consume nearly all government income. Handy, Gift of the Devil: A History of Guatemala, 94.

${ }^{62}$ See: Kenneth J. Grieb, Guatemalan Caudillo, The Regime of Jorge Ubico: Guatemala, 1931-1944 (Athens: Ohio University Press, 1979), chapter 12; Dosal, Power in Transition: The Rise of Guatemala's Industrial Oligarchy, 1871-1994, chapter 4. 'The formal advisory council foreshadows the o rigins of CACIF: To the industrialists, development policy should fall within the exclusive domain of the fuerzas vivas (a favorite self-description of the private sector in the 1980s), the planters, merchants, bankers, and industrialists who own productive enterprises and create jobs'. Dosal, Power in Transition: The Rise of Guatemala's Industrial Oligarchy, 1871-1994, 72.

${ }^{63}$ Dosal, Power in Transition: The Rise of Guatemala's Industrial Oligarchy, 18711994, chapter 4, examines Ubico's oligarchic and military background. Grieb, 
nascent urban middle class, which had only come into being under his administration (Dosal, 1995: 78).

The theme unifying these tensions is Ubico's conception of modernisation, which required international capital and the iron hand of the military to overcome Guatemala's developmental limitations. His regime was marked by such statements as: 'Public order is the cornerstone on which the tranquillity and well-being of peoples is based' and 'Peace and Order are the only conditions essential for human development' (Grieb, 1979: 32-33). Ubico's biographer, Kenneth Grieb, argues such declarations were 'designed to provide auspicious conditions for investment, both foreign and domestic' (Grieb, 1979: 33). Indeed, Grieb suggests that despite the monopolistic practices of UFCO, 'many Guatemalans, among them Ubico, exhibited a decided preference for investment from the United States and placed a high priority on the attraction of North American firms to the republic' (Grieb, 1979: 182). He explains:

The Caudillo considered the Yankees shrewd businessmen, and felt that establishing ties with the hemisphere's great power and world financial center would prove beneficial to his nation, particularly since the relative proximity to the Northern Colossus offered the trading advantages that would serve to stimulate the development of the Guatemalan export sector (Grieb, 1979: 182).

The nexus between modernisation and militarization would be manifest in Ubico's 'reform' of the labour laws wherein vagrancy laws replaced debt peonage, expanding the militarised state into labour policy. ${ }^{64}$ The labour required under such laws

Guatemalan Caudillo, The Regime of Jorge Ubico: Guatemala, 1931-1944, particularly chapter 2, provides a more personal description of Ubico.

${ }^{64}$ See Cindy Forster, The Time of Freedom: Campesino Workers in Guatemala's October Revolution (Pittsburgh: University of Pittsburgh Press, 2001), 29-30, for a discussion of the 'official myths' constructed to promote the idea that Ubico was 
amounted to nearly half the year for many indigenous men (Handy, 1984: 98); (Forster, 2001: 33). Racism predictably underlay such policies. Ubico felt Indians were unsuited to politics (which should be left to the urban elite), and that the best way to incorporate them into national life was through military conscription: the indigenous "ccome [to the military] rude, brutish, and with primitive origin, but they return learned, polished, with good manners and in condition to face life"' (Handy, 1984: 99). This view of the indigenous was widespread, and echoed by a US attaché who argued that as most Indians were illiterate, they had no idea what they were doing at the polls and should be disenfranchised (Handy, 1984: 91).

The UFCO was imbued with assumptions about race and engaged in coercive labour practices as well. Beyond the harassment of smaller landowners to sell their property and 'company store' practices that made labourers virtually indentured servants of the company (Handy, 1984: 82-83, 89), the race hierarchy of the UFCO was pronounced. Cindy Forster notes that 'lynch law reigned with perfect impunity in the banana zone to silence workers' collective actions as well as individual outbursts of rage against white managers' (Forster, 2001: 16). ${ }^{65}$ Indeed, according to Stephen Schlesinger and Stephen Kinzer, the extent of the racism displayed by UFCO alarmed its own public relations advisor, whose memo on the subject earned him 'company-wide silent treatment' (Schlesinger and Kinzer, 1983: 82).

popular among the peasantry, part of the 'historical record' that has been adopted by many scholars.

65 'In the end, United Fruit was compelled to hire Ladinos alongside the descendants of West Indians, even though the company's "scientific" racism led it to believe workers of African descent were best suited to banana production'. Forster, The Time of Freedom: Campesino Workers in Guatemala's October Revolution, 16. 
Under Ubico's tenure, the nature of disarticulation in Guatemala changes: the influence of international capital, modernizing elites, and the military increase vis-àvis traditional agricultural elites. The military becomes more directly implicated in rural labour relations and as a result the race hierarchy becomes more 'institutionally' militarized. This reading of the 1930s allows for an appreciation of the often seemingly contradictory events and coalitions that follow in the democratic opening of 1944-54 and the conservative backlash that followed. Thus the democratic opening reflects a heterogeneous coalition, some elements of which reflect a superficial reaction to recent changes in the nature of disarticulation while others aim to overcome disarticulation at a much more profound level. The conservative backlash the reform precipitates in turn reflects a coalition in favour of preserving disarticulation for 'traditional' and 'modernising' reasons.

\section{Challenging disarticulation: reforms and reaction}

Ubico lost support of the oligarchy and resigned. The military attempted to have the legislature install its preferred successor, a move that precipitated a revolt among young military officers, who had the integrity to allow for elections. ${ }^{66}$ Juan José Arévalo, a university professor with a doctorate in Education from Argentina, won 85 percent of the vote (the enfranchised population then including only literate men (Gleijeses, 1991: 36)). ${ }^{67}$

The officers were joined by civilian leaders as well. The transitional junta included
Captain Jacobo Arbenz Guzmán, who would succeed Arévalo, Major Francisco Arana,
who would lead a coup against Arévalo, and Jorge Toriello, a civilian.
67 As Dunkerley observed in 1988, the lack of scholarly treatment of this period given
its later importance is somewhat surprising. Dunkerley, Power in the Isthmus: A
Political History of Modern Central America, 134. Since then a few volumes have
been published: Forster, The Time of Freedom: Campesino Workers in Guatemala's
October Revolution; Jim Handy, Revolution in the Countryside: Rural Conflict and 
Arévalo's reform program involved two significant elements: a labour code and a social security scheme. The labour code of May 1947 affirmed the right to unionise, guaranteed the right to strike and protected workers from unfair dismissals, although agricultural unions were limited to farms employing over 500 workers and the right to strike was subject to a conciliation mechanism (Dunkerley, 1988: 139-40, Gleijeses, 1991: 41, Handy, 1984: 107-8). The Guatemalan Institute of Social Security (IGSS) was created in January of 1948 and was soon considered one of the most incorrupt and effective elements of the Guatemalan government (Gleijeses, 1991: 42). Arévalo's policies were accompanied by greater political freedoms to the urban population and less repression and a commitment to rural education to the countryside (Gleijeses, 1991: 43, 161). Yet the reforms of his administration were limited in their scope, explicitly stopping short of any land reform..$^{68}$

Nonetheless, such social changes met with resistance from elites, who 'soon branded these freedoms as intolerable excesses and began to reminisce about the times of Ubico, when "social peace" had reigned supreme' (Gleijeses, 1991: 43). ${ }^{69}$ Indeed, “"The conservative elements," the U.S. military attaché reported, "attribute labor unrest to communism, look with horror on social reforms and reflect that it was easier

Agrarian Reform in Guatemala, 1944-1954 (Chapel Hill: Univeristy of North Carolina Press, 1994); Piero Gleijeses, Shattered Hope: The Guatemalan Revolution and the United States, 1944-1954 (Princeton: Princeton University Press, 1991). Gleijeses provides the most thorough and well documented political account, and is thus most relied upon here.

${ }^{68}$ In an April 1945 speech, Arévalo claimed 'In Guatemala there is no agrarian problem ... The problem is that the peasants have lost their desire to till the soil because of the attitudes and politics of the past. My government will motivate them, but without resorting to any measures that hurt other classes'. Gleijeses, Shattered Hope: The Guatemalan Revolution and the United States, 1944-1954, 47.

${ }^{69}$ See also Dunkerley, Power in the Isthmus: A Political History of Modern Central America, 40. 
to do business, easier to make money, and easier and safer to lived during the dictator era" (Gleijeses, 1991: 48). Although the US seemed content to allow Arévalo to remain in office, confident of the strength and unwavering anti-communism of the military as well as the prospect of a more conservative successor (Gleijeses, 1991: 123-7), Guatemalan elites were no so patient. They encouraged Major Arana - the most conservative element of the junta that allowed for Arévalo's election - to attempt a coup, foiled by Arévalo but that led to three deaths, including Arana's own. ${ }^{70}$

Arévalo was succeeded in 1951 by Colonel Jacobo Arbenz, the minister of defence who had defended democracy in the Ubico transition, and who, thanks to his public reticence and prevailing prejudices of the day, won a wide spectrum of support. Organised labour was drawn to his support of democracy and became convinced of his progressive credentials, while members of the modernising elite from his home town of Quezaltenango assumed he shared their sense that limited reforms would be economically beneficial and sought to 'educate the prince' to their agenda (Gleijeses, 1991: 73). Likewise, a US advisor's racism and ignorance of the man himself brought him to the conclusion that “.... Arbenz is, in my opinion, essentially an opportunist who has strung along with the Arévalo bandwagon principally as a means of accumulating personal wealth and of giving ascendancy to his own political star. $\mathrm{He}$ has no admixtures of Indian blood, and is basically of an autocratic character"'(Gleijeses, 1991: 73, 125). ${ }^{71}$

${ }^{70}$ The plot and its demise are described in Gleijeses, Shattered Hope: The Guatemalan Revolution and the United States, 1944-1954, chapter 3. There had been other minor coup attempts against Arévalo as well, however none save Arana's was seriously threatening.

${ }^{71}$ See also Richard H. Immerman, The CIA in Guatemala: The Foreign Policy of Intervention (Austin: University of Texas Press, 1982), 106. Arbenz was in fact of middle class origins, although quite fair given that his father was German; in 1939 he 
Once in office, Arbenz in fact introduced a significant land reform and public works program. His agrarian reform plan, Decree 900, approved on 17 June 1952, involved the redistribution of all government-owned fincas and the expropriation of uncultivated land on large estates in exchange for 25 year government bonds at three percent interest (the same arrangement as the US used in Formosa and Japan; (Gleijeses, 1991: 164, Schlesinger and Kinzer, 1983: 54). ${ }^{72}$ The magnitude of the reform involved about 1.5 million acres from 107 national farms and 16.3 percent of the country's private arable land, which constituted only 3.9 percent of privatelyowned land outside of the UFCO's holdings (Schlesinger and Kinzer, 1983: 55); (Handy, 1984: 132); (Dunkerley, 1988: 148). The number of beneficiaries has been assessed at ' 100,000 heads of families', or roughly 500,000 people based on the 1950 census (Gleijeses, 1991: 156); (Schlesinger and Kinzer, 1983: 55); (Handy, 1984: 128).

The public works program was designed to create a national transportation infrastructure competitive with the US-owned network through a large road system, a new Caribbean port, and a hydroelectric dam. ${ }^{73}$ The plan largely followed the

married a member of the Salvadoran upper-class, María Vilanova, who is credited with introducing him to progressive politics and literature. The charge of personal selfinterest is particularly illogical given that Arbenz was the only officer to resign in protest of the military's occupation of Congress to strong arm it into selecting General Ponce during deliberations for Ubico's successor. Gleijeses, Shattered Hope: The Guatemalan Revolution and the United States, 1944-1954, 139-40.

${ }^{72}$ Government owned fincas were lands appropriated from German farmers during World War II, which the Ubico administration took under US pressure to do so; see Dosal, Power in Transition: The Rise of Guatemala's Industrial Oligarchy, 1871-1994, 79.

${ }^{73}$ Schlesinger and Kinzer as well as Gleijeses emphasise that the strategy was to introduce competition rather than nationalization to improve Guatemalan access to transport services. Stephen Schlesinger and Stephen Kinzer, Bitter Fruit: The Untold 
recommendations of a 1951 World Bank report on Guatemala (Gleijeses, 1991: 165); (Dunkerley, 1988: 147). After the failure to balance the 1953-54 budget, Arbenz sought to introduce the first income tax in Guatemalan history to assist in funding the reforms (Gleijeses, 1991: 169); (Schlesinger and Kinzer, 1983: 54). ${ }^{74}$

Arbenz was sympathetic to communism, joining the Guatemalan Communist Party (Partido Guatemalteco de Trabajo, PGT) in 1957, three years after his overthrow (Gleijeses, 1991: 147). The communist party distinguished itself - even in US circles (Lehman, 1997: 212) - in its incorruptibility in executing land reforms (Schlesinger and Kinzer, 1983: 58-63) (Handy, 1984: 131). Yet the reform program of the Arbenz administration was firmly capitalist in orientation: he and the PGT understood Guatemala to be at a semifeudal level of development, which required passing through a capitalist stage before socialism could be considered. As a leader of the PGT put it: 'the PGT "enthusiastically endorsed the thesis that Guatemala must first go through a capitalist stage. When we state this we were not trying to hoodwink anyone. We were convinced of it"' (Gleijeses, 1991: 148). This meant that capitalist agriculture would be developed through small farmers; Arbenz made clear that this was not redistribution for the sake of redistribution: "II is not our purpose to break up all the rural property of the country that could be judged large or fallow and distribute the land to those who work it. This will be done to latifundia, but we will not do it to agricultural economic entities of the capitalist type'" in (Dunkerley, 1990: 226).

Story of the American Coup in Guatemala (New York: Anchor Books, 1983), 53; Gleijeses, Shattered Hope: The Guatemalan Revolution and the United States, 1944$1954,165$.

${ }^{74}$ For a discussion of taxation in the Arévalo period, see: John H Adler, Public Finance and Economic Development in Guatemala (Westport, CT: Greenwood Press, 1970). 
Despite their nationalist-capitalist orientation, the reforms did engender a certain transformation in the ensemble of social relations, particularly in the countryside. As anthropologist Richard Adams observed:

An awaking of profound import did take place for many ... but it was not what usually has come under the rubric of 'ideological'. It could better be called a 'sociological awakening', for it amounted to a realization that certain of the previously accepted roles and statuses within the social system were no longer bounded by the same rules, and that new channels were suddenly opened for the expression of and satisfaction of needs (in (Gleijeses, 1991: 161).

The oligarchy likewise perceived a change. Dunkerley observes: '[W]hatever its fundamental objectives, [the reform programme] was perceived by the oligarchy as an unprecedented challenge to its economic base and a major assault upon the entire political culture erected upon hacienda' (Dunkerley, 1988: 148).

The backlash to Arbenz came from two quarters, the US, influenced by the UFCO, and the Guatemalan elites, who benefited from the ambivalence of the military and the urban middle $\mathrm{c}$ lasses to the reform program. ${ }^{75} \mathrm{~B}$ oth of these s ectors o bjected to the principles of the reform program and the social changes accompanying it: domestic elites saw a communist scare in the transformation of social relations while the US saw one in Guatemala's increasing independence from its foreign policies in the region.

Landowners, both Guatemalan and foreign, routinely underreported the value of their holdings on tax statements, causing a reaction to the amount of compensation offered

${ }^{75}$ For discussions of US involvement in Guatemala: Walter LaFeber, Inevitable Revolutions: The United States in Central America, 2nd ed. (New York: W.W. Norton \& Company, 1993); Schlesinger and Kinzer, Bitter Fruit: The Untold Story of the American Coup in Guatemala ; Dosal, Doing Business with the Dictators: A Political History of United Fruit in Guatemala 1899-1944 ;Nick Cullather, Secret Hstory: The CIA's Classified Account of its Operations in Guatemala, 1952-1954 (Stanford: Stanford University Press, 1999) Gleijeses, Shattered Hope: The Guatemalan Revolution and the United States, 1944-1954 . 
in the land redistribution. The UFCO objected vehemently to the principle of reappropriation - arguing that it required fallow land to rotate production to avoid disease - and to the amount offered, which it claimed was on the order of 25 times too little. ${ }^{76}$ The UFCO a lso felt discriminated against by the 1947 Labor Code, with its limitations on rural unions to farms with more than 500 employees. ${ }^{77}$ Guatemalan elites were also 'exasperated' by the code and 'began to brandish charges of communist infiltration with even greater gusto than did UFCO' (Gleijeses, 1991: 99).

Over the course of the reform era, the US government likewise had grown to see 'communism' everywhere in Guatemala. The UFCO certainly promoted this perception through an elaborate and well-financed public relations campaign that effectively involved leading US newspapers in presenting its point of view (Schlesinger and Kinzer, 1983: chapter 6) ${ }^{78}$ Nonetheless, many observers argue that

${ }^{76}$ Dunkerley suggests that 85 percent of the UFCO's land was fallow and that 653,197 of its 917,659 acres were subject to reappropriation, of which 15 percent were earmarked. Dunkerley, Power in the Isthmus: A Political History of Modern Central America, 149, James Dunkerley, 'Guatemala Since 1930', in Cambridge History of Latin America, ed. Leslie Bethell (Cambridge: Cambridge University Press, 1990), 227. Handy puts the figure at 250,000 of 350,000 manzanas. Handy, Revolution in the Countryside: Rural Conflict and Agrarian Reform in Guatemala, 1944-1954, 171. The company claimed on the order of 25 times the compensation offered by the government: Q15,854,849 versus the offered Q609,572, Handy, Revolution in the Countryside: Rural Conflict and Agrarian Reform in Guatemala, 1944-1954, 171-2; or, $\$ 15.8$ million, at $\$ 75$ per hectare versus the government figure of $\$ 627,527$ at $\$ 2.99$ per hectare, Dunkerley, 'Guatemala Since 1930', 227.

${ }^{77}$ Handy argues that two other fincas fit in this category, while Gleijeses claims that four did. Handy, Revolution in the Countryside: Rural Conflict and Agrarian Reform in Guatemala, 1944-1954, 171; Gleijeses, Shattered Hope: The Guatemalan Revolution and the United States, 1944-1954, 94.

78 Indeed, anonymous reports from one of the UFCO's lobbyists that alleged Guatemala aspired to take over the Panama canal (a total fabrication, which would have been impossible for the limited range of the Guatemalan airforce) became part of State Department and CIA reports. Schlesinger and Kinzer, Bitter Fruit: The Untold Story of the American Coup in Guatemala, 107. The CIA was alleged to have distributed the UFCO's public relations reports to US government officials as its own. 
there were subtler issues than mere economic imperialism at stake in defining communist for the US. ${ }^{79}$ Kenneth Lehman argues that in the 1950 s US policy-makers understood reformist governments as communist (i.e., Guatemala but not Bolivia) when they were not amenable to US pressure, w ere vocally anti-American or when reform was directly addressed at US interests; Guatemala under Arbenz 'flunked all three tests' (Lehman, 1997: 195).

Initially the US engaged in a policy of harassment from a distance, denying military sales and economic assistance, both bilateral regional aid and a much needed World Bank loan. ${ }^{80}$ When the Eisenhower administration came to power in the US, the policy against the communist became much more interventionist, leading to a CIA-sponsored coup. $^{81}$ The operation, PBSUCCESS, involved isolating Guatemala diplomatically and

Schlesinger and Kinzer, Bitter Fruit: The Untold Story of the American Coup in Guatemala, 95.

79 It should nonetheless be observed that throughout the reform era, the US government held that the policies of Arévalo and Arbenz 'victimized' US capital. Gleijeses, Shattered Hope: The Guatemalan Revolution and the United States, 19441954, 105 Dunkerley, Power in the Isthmus: A Political History of Modern Central America, 149.

80 'As Assistant Secretary Miller later explained to Congress, the World Bank "sent a mission down there ... to make some recommendations for loans. We asked [them]. ... not to do that, that we ... would exercise the veto power against such loans". Gleijeses, Shattered Hope: The Guatemalan Revolution and the United States, 1944-1954, 128-9. Dunkerley similarly observes: that the UFCO and the US government 'began to talk of the reform with the broad approval of the World Bank as 'persecuting' and 'victimizing' private enterprise'. Dunkerley, Power in the Isthmus: A Political History of Modern Central America, 149.

81 Analyses of the Eisenhower administration decision making often note the prominent positions of John Foster Dulles, Secretary of State, and his brother, Allan, head of the CIA, who had served as legal counsel to UFCO during the Ubico administration. Many of the concessions they negotiated for the company were undone by the 1952 Agrarian Reform. John Foster Dulles in particular was a forceful and visible member of the administration, dogmatically anti-communist. However, as Richard Immerman points out, 'Rather than supporting the standard portrait of Dulles leading by the strings a passive president and an overawed collection of advisers, the papers of the Eisenhower administration reveal a foreign policy resulting from a high degree of multiple advocacy, with the final decisions remaining firmly within the Oval 
convincing the military that US intervention was imminent to abandon the Arbenz administration, while simultaneously maintaining 'plausible deniability' about its intentions. ${ }^{82}$ The campaign to isolate Guatemala diplomatically in particular involved a resolution in the Organisation of American States that declared the internal control of an American state by a communist movement a actionable threat to the security of the whole region (Gleijeses, 1991: chapter 12) (Schlesinger and Kinzer, 1983: 142-5). Such diplomatic tactics, as well as measures within Guatemala such as the appointment of a brash, militant new Ambassador, were designed to convince key players, most importantly the military, that US intervention was imminent. ${ }^{83}$ On 16 June 1954 Carlos Castillo Armas, formerly a Colonel in the Guatemalan army, began his US-sponsored coup against Arbenz. On 27 June, after a US-assisted bombing

Office'. Immerman, The CIA in Guatemala: The Foreign Policy of Intervention, 14. Nonetheless, the Dulles brothers were particularly well-placed advocates for intervention, who allegedly even went so far as to manipulate the press (by discrediting a New York T imes r eporter to h is editor) to a ffect the coverage of the coup. Schlesinger and Kinzer, Bitter Fruit: The Untold Story of the American Coup in Guatemala, xiii.

${ }^{82}$ Allan Dulles' assistant Richard Bissell stated: 'The figleaf was designed to deny US involvement ... yet the success of the operation hinged on convincing the Guatemalans that the US was indeed involved'. Gleijeses, Shattered Hope: The Guatemalan Revolution and the United States, 1944-1954, 247.

${ }^{83}$ In fact, Ambassador John Peurifoy was the only of the US diplomatic staff to know details of the operation, which was organised through the CIA. Gleijeses, Shattered Hope: The Guatemalan Revolution and the United States, 1944-1954, 252. Immerman notes: 'Without massive external assistance, including foreign troops, Castillo Armas could not possibly win an armed confrontation. Consequently, Allen Dulles and the other top CIA officials based their strategy on the assessment that both Arbenz and his military staff could be deceived into believing that Castillo Armas was at the head of a major insurrectionary force and that, if necessary, direct United States support waited in the wings. Perceiving such a challenge, the strategists predicted, the military would desert the revolution and Arbenz would resign. The actual scenario followed the CIA prognosis almost exactly'. Immerman, The CIA in Guatemala: The Foreign Policy of Intervention, 162. 
campaign and a strategic misinformation campaign about the actual numbers and support for the coup leaders, Arbenz resigned. ${ }^{84}$

In its commitment to capitalist development and limited nature of its agrarian reform (relying on UFCO and national lands), Arbenz challenged elements of the subjective but not the objective dimensions of disarticulation: his reforms did not significantly alter the material bases of power of elites in Guatemala. The conservative backlash to his policies was wider than 'mere' US imperialism, although Arbenz's strong reputation within the military would undoubtedly have maintained his presidency longer had the US not gotten involved. The withdrawal of support from the military and the lack of strong support from the urban middle classes allowed for conservative elements to reassert their control. This would require a stronger hand than before the reform era, which did raise expectations in the rural population: precisely the conditions to which emergent counterinsurgent state would address itself with US support.

\section{The post-reform ensemble of social relations}

Disarticulation in the Guatemalan ensemble of social relations is reconstructed in the post-reform era with significant involvement of the US in the military and the economy. The modern Guatemalan military owes a significant debt to US funding after the coup. Although the military was quite strong under the Ubico regime, there was a significant contribution by the US after 1954, through the direct transfer of materials and services via grant, sales and credit programmes originating in the 1950 s,

${ }^{84}$ Details of the coup are related in Schlesinger and Kinzer, Bitter Fruit: The Untold Story of the American Coup in Guatemala, chapters 12 and 13; Immerman, The CIA in Guatemala: The Foreign Policy of Intervention, chapter 7; Gleijeses, Shattered Hope: The Guatemalan Revolution and the United States, 1944-1954, chapter 14. 
training in the leadership of armed forces, and police assistance (Holden, 1993: 288). In 1962, the US established a secret base for counterinsurgency training in the department of Izabal, directed by members of US special forces. Further, 2,280 Guatemalan military personnel received US training between 1950 and 1970, both in the US (626 trainees) and at the US Army School of the Americas in Panama $(1,654$ personnel; (Sharckman, 1974: 197). The course curriculum at the latter emphasised counter-guerrilla warfare and provided instruction in US military doctrine and ideology. The move to a counterinsurgency state involved changes in the required weaponry: from tanks, artillery, bombers to less expensive light weapons, mobile communications, and helicopters. This transition occurred in 1966-70, and served as a model for other US military assistance projects (Sharckman, 1974).

Police training provided by USAID also focused on anticommunist ideology and counterinsurgency strategies, and 'professionalizing' the police force. Over 30,000 Guatemalan police personnel received such training by 1970 , which included programmes on 'The Threat to Latin America', 'The Changing Society', and the 'Implementation of Modern Scientific Aid' (Sharckman, 1974: 199). Police equipment grants (not including training or services) from the US to Guatemala in the period 1957-71 amounted to $\$ 9,047,914$ (\$US1990; (Holden, 1993: 305).$^{85}$ Although Guatemala at times distanced itself from the US (notably during the Carter administration, because of its onerous emphasis on human rights), this was only after the US had established it as one of the best trained and equipped militaries in the

85 'Thus, it would seem that the United States gave the Guatemalan police forces during the 1960s nearly all of their handguns and nearly half their shoulder weapons...'. Robert H. Holden, 'The Real Diplomacy of Violence: United States Military Power in Central America, 1950-1990', The International History Review 15, no. 2 (1993): 305-6. 
region. Furthermore, at this point it was able to purchase military supplies from Israel and the Argentine dictatorship. ${ }^{86}$

As the military developed institutionally, it also grew to become a significant economic actor. Initially the economic ambitions of the military were contained to the opportunistic, personal accumulation of senior officers (Dunkerley, 1988: 462). For example, in the 1970s a sparsely populated area called the Northern Transversal Strip, marked for 'colonisation' as a development mechanism, was ultimately so appropriated by military elites that it became known as the 'Land of the Generals'. Later, however, this accumulation became more institutionalised, as per the military itself. The military established a bank and invested in such diverse activities as real estate construction, insurance and manufacturing; likewise it often controlled semiautonomous state enterprises (Dunkerley, 1988: 462). As Regis Debray explains, with the creation of an Army Bank 'military hegemony grows in time and in space with foreign investment...' (Debray, 1978: 352).

The US d evelopment s trategy for p ost-reform Guatemala was i mplemented through the World Bank, USAID and the private US consulting firm, Klein and Saks (K\&S) ${ }^{87}$

\footnotetext{
86 'At least until 1981 the Israeli connection represented a clear alternative to US military aid; thereafter it tended to become more of a surrogate although still providing the Guatemalan military with an appreciably wider margin of independence from Washington than was possessed by their regional counterparts. ... Argentine expertise in urban counter-insurgency operations gained during the 'dirty war' in Buenos Aires resulted in the effective destruction of ORPA's (guerrilla group, discussed further below) network in the capital in 1981'. Dunkerley, Power in the Isthmus: A Political History of Modern Central America, 490. 'Given Israel's own dependence on US military hardware, and Washington's traditional interest in shutting out potential nonhemispheric military suppliers, it seems likely that Israel stepped in only with the permission - perhaps even encouragement - of the United States'. Holden, 'The Real Diplomacy of Violence: United States Military Power in Central America, 1950-1990': 304.
} 
These post-intervention economic policies differed from the development ethos adopted by many other Latin American states at the time, (as for example that of the UN Economic Commission for Latin America), in their emphasis on state support for private enterprise rather than state regulation. Prominent features of the World Bank/USAID/K\&S plan included dismantling restrictions on foreign investment and attracting US investors to Guatemala ('a campaign in which $\mathrm{K} \& \mathrm{~S}$ played a crucial role'), private sector concessions and subsidies, an emphasis on export agriculture and the financing of infrastructure through World Bank and US funds (Jonas, 1974: 79). Such financing insulated elites from taxation, a perennial problem in Guatemala, which has among the lowest taxes in Latin America and a highly regressive tax system.

The expansion of the 'modernising' business elite lie in the post-intervention era and foreign participation in the economy. From the 1950s to the 1970s, US investment in Guatemala increased significantly: 37 percent in the 1950s and 128.8 percent in the period 1959-69, bringing it to US\$888 million in 1969 (Tobis, 1974: 132). The composition of this investment heavily favoured manufacturing over agriculture previously the dominant s ector - so that it grew to a ccount for 36.3 percent of US direct investment (US\$ 46.6 million) in Guatemala in 1970 (up from 10.4 percent in 1963; agriculture declined from 27.2 percent to 23.2 percent over the same period); (Tobis, 1974: 133). The only other sector to increase during this period was commercial capital: US firms operated primarily through the acquisition of local firms.

${ }^{87}$ Jonas claims that the World Bank was pressured to approve an $\$ 18.2$ million highway loan to Guatemala; the US had rejected Arbenz' petition for the same loan. Here USAID is used for simplicity; during the early 1950s the agency was called the International Cooperation Agency. Susanne Jonas, "'Showcase" for Counterrevolution', in Guatemala, ed. S usanne Jo nas and D avid T obis (Berkeley, C A: North A merican Congress on Latin America, 1974), 77. 
This strategy created joint ventures, which further tied business elites to international capital. Furthermore, many firms were classified as 'new industries' after acquisition, exempting them from corporate tax for five years and granting them duty-free imports (Tobis, 1974: 133).

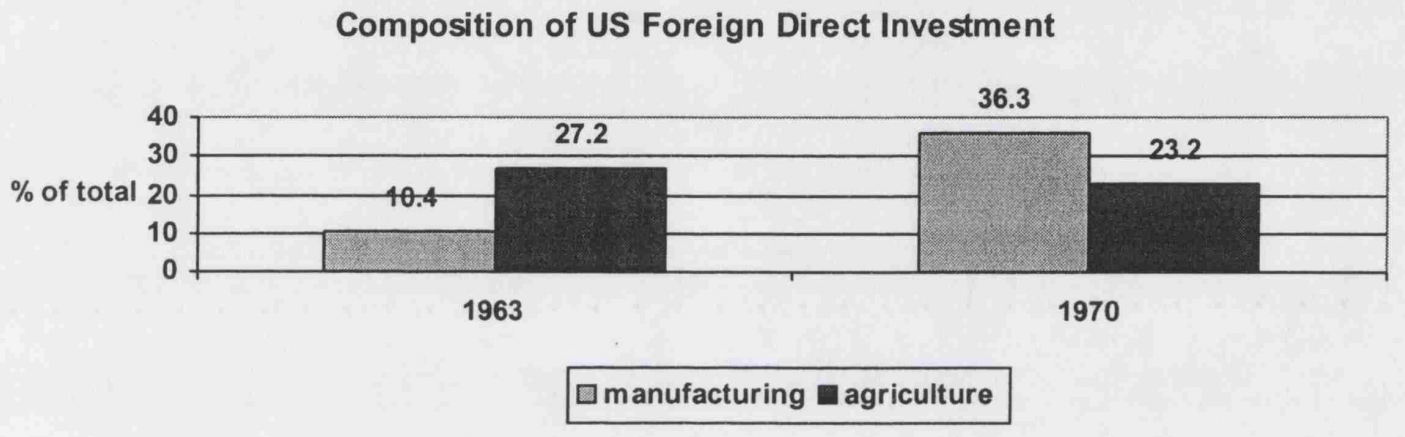

Source: (Tobis, 1974: 133)

The changes in US investment in Guatemala were accompanied by a change in the composition of economic elites. Thus the Comité Coodinador de Asociaciones Agricolas, Comericiales, Industriales y Financieras (CACIF; 1957), Asociación Nacional de Café (ANACAFE; 1960) and other post-intervention business associations became increasingly powerful vis-à-vis their pre-intervention predecessors. CACIF and the American Chamber of Commerce increased in authority with the expansion of US capital in Guatemala in the 1960s, both in traditional agricultural sectors and in manufacturing and commercial sectors (Dunkerley, 1988: 463). CACIF began as a forum 'to allow all of private enterprise to cooperate when necessary' and has since its inception promoted internationally-oriented economic interests (Adams, 1970: 340-1). 'The general position of CACIF was conservative, however, and it did not hesitate to ridicule organizations that reflected a pre-1954 nationalism' (Adams, 1970: 340). The composition of business associations is 
particularly significant because, as Dunkerley notes, 'the bourgeoisie did not greatly depend upon direct representation though political parties. ... [Policy-making] fell largely to the corporate associations of capital ...' (Dunkerley, 1988: 462-3).

The US reconstruction efforts in the post-reform state reinstitutes the highly privatised strategy of governance that extends back to before the reform decade, but under a new modernising ethos. This ethos more actively involves elites in the international economy and structures the Guatemalan state to be receptive to foreign capital. The result reflects a form of disarticulation structured precisely to allow for the continued mutual reinforcement of the dominant groups of society.

The 'modernisation' efforts occurred on a regional level as well, with the creation of a Central American Common Market (CACM) in the 1960s. The idea originated with an effort by the UN Economic Commission for Latin America (Comisión Económica para América Latina, CEPAL) in 1958, which by 1960 was then largely displaced by the US, a move which changed the nature of the common market from one based on regional planning to one based on a free market with the help of US\$100 million in assistance (Jonas, 1974: 88). The notion of economies of scale was transformed into a definition of development based on the concept of 'promotion': the targeting of a specific s phere to a ttract for foreign investment, c elebrated as a s ource of t echnical expertise. However, the incentives to attract these industries were so generous as to compromise any contribution they might make to the local economy (Jonas, 1974: 96) ${ }^{88}$ The CACM strategy reflected the logic of social disarticulation: it sought to

88 These incentives included no restrictions on the possibility of taking over the locally-owned e nterprise, exemptions from c orporate income tax, d uties on i mports, and unrestricted profit remittances. Susanne Jonas, 'Masterminding the Mini-Market: 
establish market-widening through expanding the regional scope of the market, rather than through m eaningful s ocial $r$ eform. Ultimately the CACM dissolved b ecause of tensions over its impact on other countries in the region. Smaller and poorer countries charged that their economic positions had worsened to the benefit of the relatively more industrialised states in the region, Guatemala and El Salvador.

\section{Contradictions of disarticulation: rebellion and popular organising}

Resistance to the dominant elements of the post-reform era social ensemble in Guatemala as popular organising and rebel activity occurs in three broad periods: the decade 1962-72, where early attempts at guerrilla warfare are fraught with difficulty and effectively repressed by the state, the period between the decimation of this early effort and the 1976 earthquake, and the period from 1976 leading up to the genocidal counterinsurgency campaigns of 1980-1983.

The period 1962-72 is marked by the emergence of a guerrilla movement, led by disaffected army officers. ${ }^{89}$ The CIA's use of a Guatemalan military base without

U.S. Aid to the Central American Common Market', in Guatemala, ed. Susanne Jonas and David Tobias (North American Congress on Latin America, 1974), 96-97.

${ }^{89}$ For a timeline of this period, see Dunkerley, Power in the Isthmus: A Political History of Modern Central America, 450-2. Regis Debray's reflections on the period can be found in, Régis Debray, The Revolution on Trial: A Critique of Arms, trans. Rosemary Sheed, 2 vols., vol. 2 (New York: Penguin Books, 1978). For discussions of the Maya in this period from an a nthropological perspective, see, inter a lia: Beatriz Manz, Refugees of a Hidden War (Albany: State University of New York Press, 1988); Ricardo Falla, Massacres in the Jungle: Ixcán, Guatemala, 1975-1982, trans. Julia Howland (Boulder: Westview Press, 1994); Robert M. Carmack, ed., Harvest of Violence: the Maya Indians and the Guatemalan Crisis (Norman: University of Oklahoma Press, 1988); Smith, ed., Guatemalan Indians and the State, 1540 to 1988 . The classic biography from an indigenous perspective is Rigoberta Menchú, $I$, Rigoberta Menchú: An Indian Woman in Guatemala, trans. Ann Wright (London: Verson, 1984). Discussions of the controversies it raised can be found in: Arturo Arias, ed., The Rigoberta Menchú Controversy (Minneapolis: University of Minnesota Press, 2001). 
proper Army consultation provoked a nationalist coup attempt in November 1960. In 1961 those unsuccessful rebel leaders returned to join the communist party (Partido Guatemalteco de Trabajo, PGT), which had committed itself to a strategy of guerrilla warfare. The Fuerzas Armadas Rebeldes (FAR), as this effort would be later known, focused on the Eastern areas of Izabal province and the town of Zacapa. The movement suffered from two strategic problems. First, the military and political arms of the effort were kept separate: the guerrilla leadership was excluded from political decision making, which 'engendered acute problems of coordination' (Dunkerley, 1988: 454). Second, the FAR and its related forces pursued a strategy of direct military confrontation without any organisational efforts among the population, which was later identified even by the FAR itself as 'the overly adventurous and voluntarist features of a rigid foquismo' (after Ché Guevara's and Régis Debray's foco theory; (Dunkerley, 1988: 452$).^{90}$

During this initial post-coup period, another form of 'popular' organising emerged in the form of Acción Católica, a religious developmentalist movement with the goal of creating small-scale farmer-entrepreneurs. This new form of development reorganised traditional agriculture, leading to a transition away from traditionally significant crops, such a corn, which has spiritual significance to the Maya, towards income generating cash crops (Arias, 1990: 235). However, as Arturo Arias notes, 'despite their reformist character, the growth of the cooperatives brought about serious conflicts with the local powers, thus a ccelerating the radicalisation of $A$ cción Católica's m embers and their mentors' (Arias, 1990: 233). The state tolerated the cooperative movement to the

\footnotetext{
90 Foco theory posits that under some conditions of extreme exploitation a revolutionary consciousness essentially already exists and thus a small group of guerrillas can initiate a revolution and the people will follow, without any need for extensive outreach or organisation.
} 
extent it could remain 'apolitical'. USAID supported cooperatives in its rural development programme for the 1960 s, but alienated participants through its attempt to be 'nonpolitical', many of whom saw USAID as working to destroy the existing movement (Brockett, 1988: 110). Participants became divided into those who feared being labelled communist - some members of Acción Católica and priests who argued that they 'did not want to get involved in politics' - and those who felt disappointed with the failure to realise a political a lternative and became $r$ adicalised through the experience (Arias, 1990: 234). The cooperative movement was coopted by the state, which became involved under the guise of the provision of technical development and credit. However, the movement had already established the foundations for indigenous organising.

After the destruction of the FAR through the assassination of its remaining leadership in 1972, organising entered a phase of more secret activities that involved multicultural alliances. A group of dissident FAR members reorganised in the predominantly indigenous region of El Quiché under the banner of the Guerrilla Army of the Poor (Ejercito Guerrillero de los Pobres, EGP). ${ }^{91}$ The EGP rejected foco theory and spent years cultivating a support base before it engaged in armed combat, initially in 1975 but more frequently only from 1978 onwards (Dunkerley, 1988: 455-6). The Organización Revolucionaria del Pueblo en Armas (Organisation of the People in Arms, ORPA) similarly pursued a strategy of 'gestation', having been established in 1971 but only emerging publicly in 1979 (Brockett, 1988: 112). The ORPA, like the EGP, shared an emphasis on organising in indigenous areas (the Western Highlands). Though smaller, ORPA attracted a broader base of support than the EGP, including

91 A map of of the geographical distribution of guerrialla groups can be found in Appendix 2. 
middle-class intellectuals, and the FAR, whose programme was less populist (Dunkerley, 1988: 483). During this period the Comite de Unidad Campesina (Committee of Peasant Unity, CUC), an indigenous-led but multicultural/multiracial peasant union emerged, also pursuing a strategy of secret organising, going public only in 1978. This period was one of relatively less o vert conflict between the state and popular forces, however, the 1976 earthquake would re-open this uneasy tension.

The far-reaching organisational infrastructure of the cooperative movement allowed it to respond to the 1976 earthquake that devastated Guatemala, thus giving it the potential to control a great deal of the international aid that poured into the country. The cooperative movement interfaced with the international community and to an extent publicized the plight of indigenous Guatemalans, increasing the perception that it represented a threat to the state. In response, the army monopolised much of the aid, reinforcing social control while using the resources for the pursuit of individual profit (Arias, 1990: 243). This situation was codified into law by the 1978 New Cooperative Law, which essentially put the cooperative movement under military control (Sollis, 1995: 529). Counterinsurgency activities immediately after the earthquake targeted cooperative members, 200 of whom 'disappeared' in the department of El Quiché in the year and a half following the earthquake (Brockett, 1988: 111).

A number of public actions by progressive forces in the years leading up to the most brutal counterinsurgency campaign were met by reactionary responses that fuelled support for the guerrilla. B y 1977 there w as w idespread s upport for u nion rights; a miners' march that year drew a crowd of 100,000 supporters in the capital (Dunkerley, 
1988: 471).$^{92}$ The next year, the CUC went public and organised thousands of Indians to march under its banner at the May Day demonstrations. Greg Grandin observes, 'Not since 1839, when Rafael Carerra's peasant army occupied Guatemala City had this many Mayans gathered together as Indians in a show of oppositional force in the ladino capital' (Grandin, 1997: 18, emphasis original). In 1979, ORPA would make its efforts public as well.

The nature of the responses to these activities shows how the political involvement of the indigenous p opulation p rovokes a larm. 'Given the d eep-seated m istrust b etween Mayans and ladinos, [its multiethnic character] perhaps was the CUC's most radical and threatening aspect' (Grandin, 1997: 17). Thus later in May 1978, the army called indigenous peasants to the town of Panzós, ostensibly for a meeting to resolve conflicts over access to traditional lands that had been usurped for cattle farming, only to fire on the defenceless crowd which it immediately buried in a mass grave. ${ }^{93}$ In 1980, the leader of the CUC (Vincente Menchú, Rigoberta's father) and 39 peasants who took their case for protection from arbitrary repression to the Spanish embassy were burned alive in an army attack (which took place against the wishes of the Spanish ambassador)..$^{94}$ These two events remain watersheds in the national

92 The success of this march and other instances of Indian-ladino cooperation encouraged the CUC to be a multiethnic rather than Indigenous-based organisation.

93 Dunkerley notes, 'According to later military reports a major clash with 'subversives' took place, which explained neither the immediate burial of the dead in a single mass grave - alleged to be dug by tractors two days earlier - nor the fact that only one soldier was hurt, with a slight wound to the leg. Well before the Church issued its detailed version of a premeditated mass execution the regime's clumsy rendition of events had been undermined by eye-witness accounts...'. Dunkerley, Power in the Isthmus: A Political History of Modern Central America, 477. See also Handy, Gift of the Devil: A History of Guatemala, 245-6.

${ }^{94}$ Handy notes that 'Only the ambassador and one peasant survived. The peasant was later kidnapped from the hospital where he was recuperating from his injuries'. Handy, Gift of the Devil: A History of Guatemala, 247. 
consciousness and provoked greater sympathy for the guerrilla in the indigenous population.

\section{Counterinsurgency in Guatemala}

Counterinsurgency operates with the rhetoric of development, but aims to remove the rural population from a context of potential guerrilla recruitment. In Guatemala two main strategies of control were employed: the destruction of villages (over 400 by the end of the campaign), with the relocation of the population into 'model villages', and the forced recruitment of men into paramilitary civil patrols for rural surveillance.

While o utwardly their creation $w$ as d efended through the discourse of development (and indeed with food to distribute from international relief efforts) model villages in fact impoverished peasants and subjected them to specific resocialisation processes (Handy, 1984: 262); (Brockett, 1988: 119).95 'Even the military officer in charge of the National Reconstruction Committee ... admitted that there were about 250,000 peasants, "among them children who are forced to eat dirt"' (Handy, 1984: 261). The further destruction of indigenous culture was explicitly promoted through techniques such as discouraging the use of Mayan languages among children, the assassination of

\footnotetext{
${ }^{95}$ External actors accepted the developmentalist pretext for the model villages. USAID and the international NGO CARE established positions for joint military assistance / development programmes. Howard Sharckman, 'The Vietnamization of Guatemala: US Counterinsurgency Programs', in Guatemala, ed. Susanne Jonas and David Tobis (Berkeley, CA: North American Congress on Latin America, 1974). Roads, for example, and other infrastructure that was ostensibly for development, had a strong military purpose. Charles Brockett notes: 'The Agency for International Development, which provides much of the financing, defends [roads] as meeting developmental objectives, but many observers in the region see other purposes: "You'll see right away that there is always a military outpost at the end of all the roads in the Altiplano. The roads are for the security of the country". Brockett, Land, Power and Poverty: Agrarian Transformation and Political Conflict in Central America, 119.
} 
Indian elders, and making different indigenous groups live together specifically to erode ethnic identities (Handy, 1984: 260); (Brockett, 1988: 118).

Patrullas de Autodefensa Civil (PACs, civilian self-defence patrols) were created ostensibly to guard communities from the guerrilla. They included at their height 900,000 people, nearly 80 percent of the male population in rural indigenous areas (Human Rights Office of the Archdiocese of Guatemala, 1999: 119). Although communities participated in PACs under threat of elimination, indoctrination was also used to promote participation. In the words of the Guatemalan army, 'Civic education is part of psychological action; it begins by providing thorough information about the security forces' chances of success in the counter-subversion struggle' (Human Rights Office of the Archdiocese of Guatemala, 1999: 121). As James Dunkerley notes, 'the primary purpose of the patrols was less military than to ensure individual registration, control of movement, and dissemination of propaganda. The ambitious long-term objective was a coercive state-based 'incorporation' of the campesino and particularly the Indian into the 'nation"' (Dunkerley, 1988: 496-7).

Yet, despite the roots of its possibilities in racial anxiety and its genocidal activities on the one hand, the counterinsurgency project at the same time opens the possibility of social control through cultural and identity appropriation. Jennifer Schirmer describes the military's construction of the 'Sanctioned Maya' which is a model of the indigenous 'constructed and continually reconstructed through the military's optic, deprived of memory, and mute to the recent "subversive" past' (Schirmer, 1998: 115). She argues,

Such re-creational and guardian discourse should also alert us to the military's view of the indigenous community as a child needing to be disciplined, "ladinoized", entrepreneurized-that is, "forged" to fit the 
"new" Guatemalan state... Part of this forging, it is believed, is accomplished by appropriating Mayan symbols to "rescue the Indians' mentality until they feel part of the nation" (Schirmer, 1998: 114).

Identity becomes part of the terrain for control, the economic dimension of which is manifest in the need to control the population in a specific modernisation process (and is indeed reflected in the post-conflict state through the commodification of the indigenous identity, see Chapter 4).

The methods of counterinsurgency are informed by its assumptions about society, as are its outcomes. Counterinsurgency destroys what it constructs as the enemy, but it is also productive of a new social order: partly through the elimination of challenges and partly through resocialisation through violence. It is the violent management of social change towards a post-challenge order.

The Recovery of Historical Memory Project (REMHI) of the Archdiocese of Guatemala's H uman R ights O ffice is c onsidered the m ost c omprehensive survey of human rights abuses during the war. According to the REMHI interviews, counterinsurgency was characterised by constant tension in the rural population, generalised, indiscriminate violence against civilians, public displays of horror and blatant impunity for government perpetrators (Human Rights Office of the Archdiocese of Guatemala, 1999: 9-10). Significantly, violence itself had explicit cultural overtones, including the way corpses were left to be found by indigenous communities, the targeting of children as victims, and the destruction of traditional crops (Human Rights Office of the Archdiocese of Guatemala, 1999: 19, Chapter 2, $41)$. 
The social and psychological effects of this indiscriminate climate of terror led to the disruption of community life and to an atomisation of community forms. The societal effects involved restricted communication among people, withdrawal from community organisations, social isolation, and community distrust (Human Rights Office of the Archdiocese of Guatemala, 1999: 10-11). This social disruption is r einforced on an individual level by feelings of humiliation, powerlessness and difficulty in distinguishing the boundaries between the real and imagined (Human Rights Office of the Archdiocese of Guatemala, 1999: 11-12). There are physical effects as well, which range from paralysis to acute panic attacks, and ailments such as immunological dysfunction and pain (Human Rights Office of the Archdiocese of Guatemala, 1999: 11-12). There is some suggestion that suicide - a social issue that rarely affects indigenous cultures - increased dramatically as a result of the counterinsurgency campaign (Human Rights Office of the Archdiocese of Guatemala, 1999: 15-16). ${ }^{96}$

To reiterate, the underlying rationale for controlling the rural population is its assumed lack of rationality about the development project. A particular source of anxiety is the collective form where it is impossible to distinguish the naive peasant from the contaminated rebel. This anxiety is amplified by the indigenous, understood to be ontologically - racially - different and historically hostile. The counterinsurgency project deliberately aims to disrupt rural life, to disembed it from existing social networks, and to reconstruct society in a particular political-economic ideal. Its outward regulatory form is very conspicuous and violent. However, in the use of terror

\footnotetext{
96 The report notes that in Rabinal municipality, there had been only one suicide in the 10 years prior to the government $c$ ampaign there, while $d$ uring the repression there were eight suicides in a two year period. The forensic anthropologists coordinating many of the investigations into the human rights abuses in Guatemala have published a volume on the massacres in that region: Equipo de Antropoloígia Forense de Guatemala, Las Masacres en Rabinal, 2nd ed. (Guatemala: EAFG, 1997).
} 
and other counterinsurgency techniques, an inward regulatory function is created. The new social form silences both community organisations and individual self-expression. Technologies of cultivating mistrust within a community are accompanied by technologies of cultivating shame within individuals, who internalise community atomisation. Counterinsurgency does not merely control the community, it aims to control the individual.

\section{Counterinsurgency as prelude to the peace process}

The nature of counterinsurgency as socially and subjectively productive must be considered in understanding the ensemble of social relations preceding the peace process. Counterinsurgency structurally promotes a particular form of modernisation open to transnational capital. It does this by understanding political and social disarticulation as strategic to development. Disarticulation promotes the continued orientation of elite interests towards the international, provides the coercive framework for such development, and the conduit for the 'intellectual and moral leadership' to rationalise the new (re)iteration of society in this form. Likewise, culturally and subjectively, counterinsurgency serves to disembed traditional cultures and to atomise them. The anxiety of culture, race and modernity is resolved through the destruction and subsequent reconstruction of the 'other'. The 'Sanctioned Maya' reflects the selective use of cultural symbols in a dehistoricized reconstruction of identity in the service of the dominant groups' vision of the nation-state. This is the political subjective dimension of counterinsurgency, the postcolonial passive revolution. In what follows, the post-counterinsurgent ensemble of social relations will be considered through three lenses: the nature of the state economy and the associated 
understandings of development of economic elites, the new terrain of 'civil society', and the new discourses of indigenous identity.

\section{The structure of the 'national' economy}

Modernising elites are associated with several sectors of the economy which had risen in importance since the 1960s: banking, non-traditional agriculture, maquila production, and tourism. These sectors have a new relationship to transnational capital and thus require a new role for the state in the economy, vis-à-vis regulation and infrastructure. These requirements are understood through a particular concept of the 'national' economy as extrapolated from the microeconomics of the firm, which allows for the development and (re)construction of the privatised state. This is not the deconstruction of a welfare / developmentalist state, but the positive construction of the neoliberal state, a phenomenon overlooked by critiques of neoliberalism that see it only as a negative, economic project. However, this constructive aspect of neoliberalism strongly influences the position of modernising elites, represented by CACIF, and indeed the IFIs, in the peace process.

\section{Banking}

After rising in importance throughout the post-reform era, Guatemala liberalised - and as a result, significantly expanded - its financial sector at the end of the 1980s. This programme involved several strategies designed to increase competitiveness and to strengthen the solvency of the sector, to modernise the financial system, and to improve 'entry-exit' conditions in the financial services market (IMF, 1995: 42-43). (The modernisation efforts were supported by the Inter-American Development Bank (IMF, 1995: 43)). The n umber of $p$ rivate b anks nearly d oubled in the p eriod $1986-$ 1994, increasing from 15 to 27 (IMF, 1995: 110). 
The financial services sector is not limited to banks per se: it includes a number of large financial groups, which include both financial and non-financial enterprises, usually with offshore operations. Many also operate fianciadoras, which function in many ways as unregulated banks: they can provide financial services other than checking accounts and foreign trade transactions and are not subject to reserve requirements (IMF, 1998: 26). The total number of banking and financial institutions rose from 25 in 1989 to 53 in 1997 (IMF, 1998: 26).

The banking sector reflects the logic of neoliberal modernisation. Liberalisation of the sector does not affect the concentration of economic power, and indeed relies on it in practice if not in theory. Forest Colburn and Fernando Sánchez note that large business groups took advantage of the banking boom to develop their own lines of credit; they quote a central banker from the region: 'Almost all of the large business groups of our region have a bank that functions almost as the treasury of their business' (Colburn and Sánchez, 2000: 73, translation mine). The self-assessment of this sector attributes its success to an aggressive modernisation campaign and its investment in personnel (Colburn and Sánchez, 2000: 71).

\section{Non-traditional agricultural products}

Non-traditional agricultural products grew at a rate of about 15 percent a year in the period 1992-97 (IMF, 1998: 30). The growth of this sector is attributed to two phenomena; the improvement of technology and cultivation methods, as well as the development of 'niche' markets, such as supplying the US with fresh berries in its offseason (IMF, 1998: 30). The logic of non-traditional agricultural products, therefore, extends beyond that of the traditional agricultural economy, as it requires not just 
greater capital investment (new technologies) but a qualitatively new orientation to the global economy through the identification and development of niche markets. This dimension is reflected in the understanding of the national economy through the microeconomic lens, discussed below.

Non-traditional agricultural exports in millions of \$US

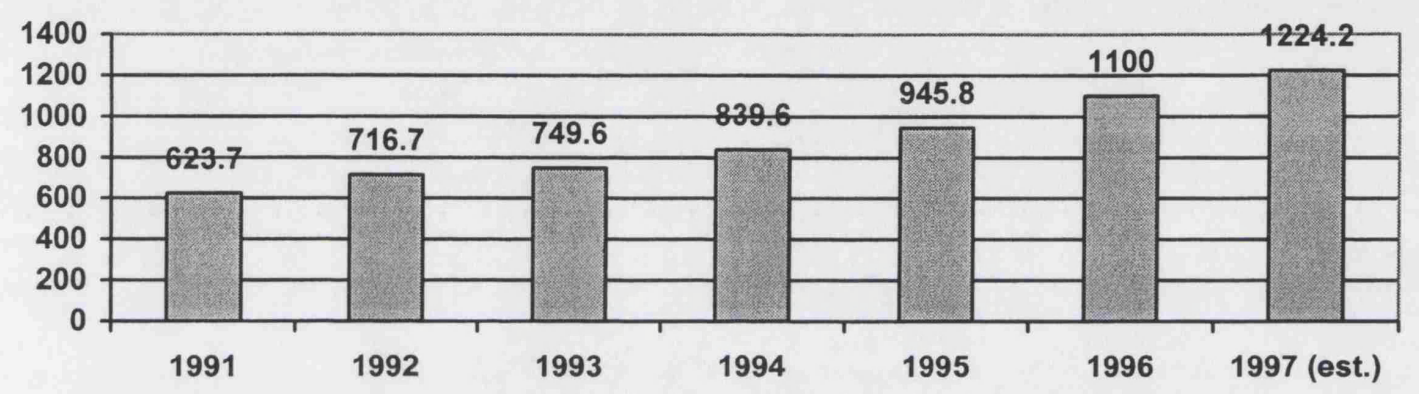

Source: (IMF, 1998: 50)

\section{Maquila}

Also understood as a 'non-traditional' export by the IMF, the maquila sector began in Guatemala in 1978 with the Zona Libre de Industria y Comercio (ZOLIC) (Pérez Sáinz, 1996: 165). This sector attracts business through a particular regulatory environment that includes tax and customs exemptions and favourable exchange rates (Pérez Sáinz, 1996: 164). According to the private sector organisation for nontraditional exporters, the number of maquila enterprises rose from 41 in 1986 to 400 in 1992, going from a workforce of 5,000 to about 70,000 in the same period (Pérez Sáinz, 1996: 166-8). ${ }^{97}$

97 See also Asociación Gremial de Exportadores de Productos No Tradicionales, ([cited 21 March 2002]); available from http://www.agexpront.com/ingles.htm. 
IMF data also shows a dramatic increase in the value of the sector:

Guatemalan maquila exports in millions of \$US

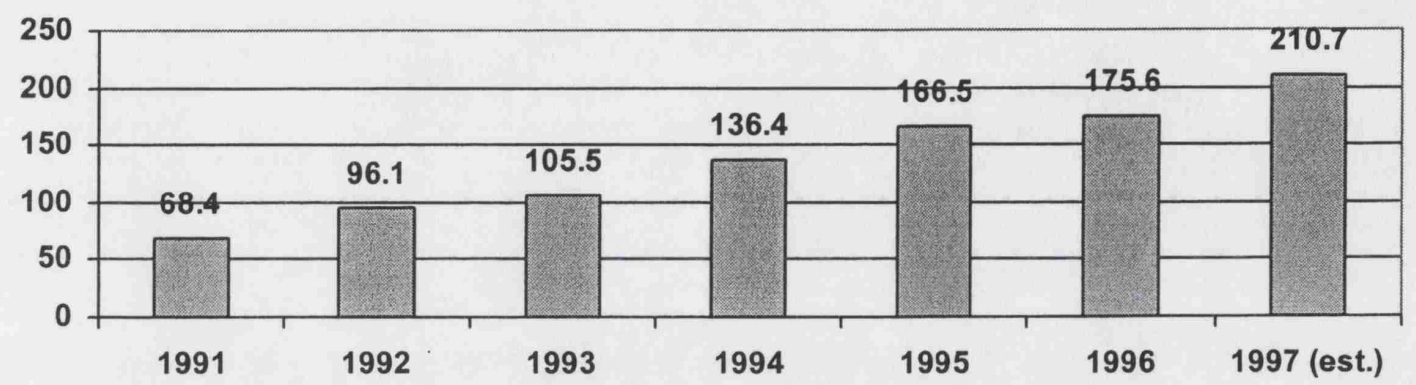

Source: (IMF, 1998: 50)

This reflects an increase of 21 percent per annum, 1991-96 (IMF, 1998: 30).

The nature and structure of the maquiladora sector are not insignificant. The sector is demographically specific, relying overwhelmingly on young, single women: women comprise 78 percent of the workforce and their average age is 21 years old (Pérez Sáinz, 1996: 169-70). There is little job security in such positions, which offer very short contracts: in Guatemala the norm is 12 months (Pérez Sáinz, 1996: 174). Juan Pablo Pérez Sáinz maintains that the maquiladora sector in Guatemala consciously located itself 50 kilometres away from the capital, to distance itself from organized labour and to position itself in a more docile, rural, indigenous workforce (Pérez Sáinz, 1996: 173). Indeed, he argues that this form of industrialisation reproduces the labour structures of the plantation.

Maquila represents the subjectivity of neoliberalism on several levels. The development of the maquila sector consciously built on the weakness of the ZOLIC experience: the lack of infrastructure and labour, and the state's own managerial incapacity to deal with such projects (Pérez Sáinz, 1996: 165). The understanding of 
the development of those elements - infrastructure, labour, and the appropriate regulatory environment - proceeds within the logic of neoliberal development. The requirements for global competitiveness allow for the state's participation in creating infrastructure, however, state regulation comes in the forms of incentives for foreign investment. The state may be involved in providing or indeed training labour, but it must be inexpensive, unorganised labour. The Trade Association for Exporters of NonTraditional Products attributes the success of the maquila sector to three factors: the level of production efficiency in the sector, the maintenance of low prices that allow competition with Mexico, which benefits from trade preferences with the US in maquila production, and the ability to produce products as sophisticated as those assembled in Mexico (Asociación Gremial de Exportadores de Productos No Tradicionales, 24).

\section{Composition of Exports}

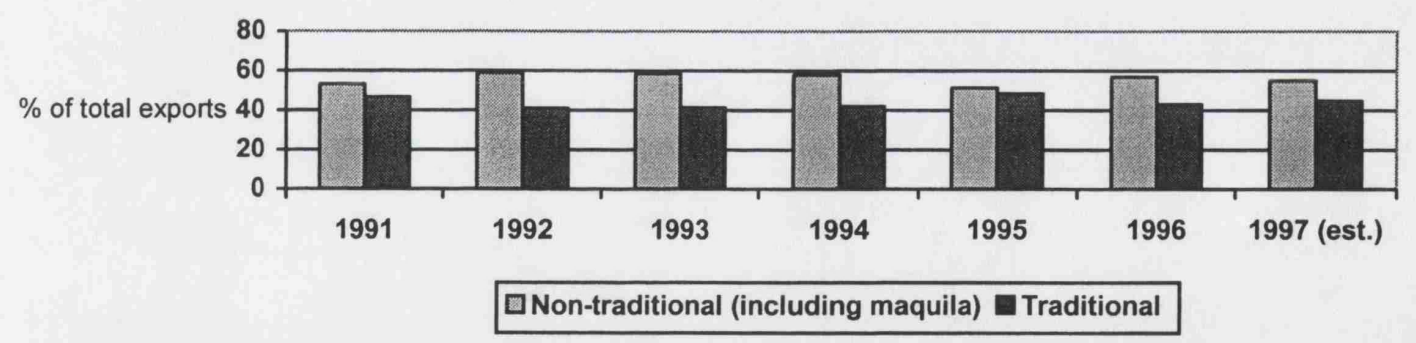




\section{Tourism}

Guatemalan tourism earnings in millions of \$US

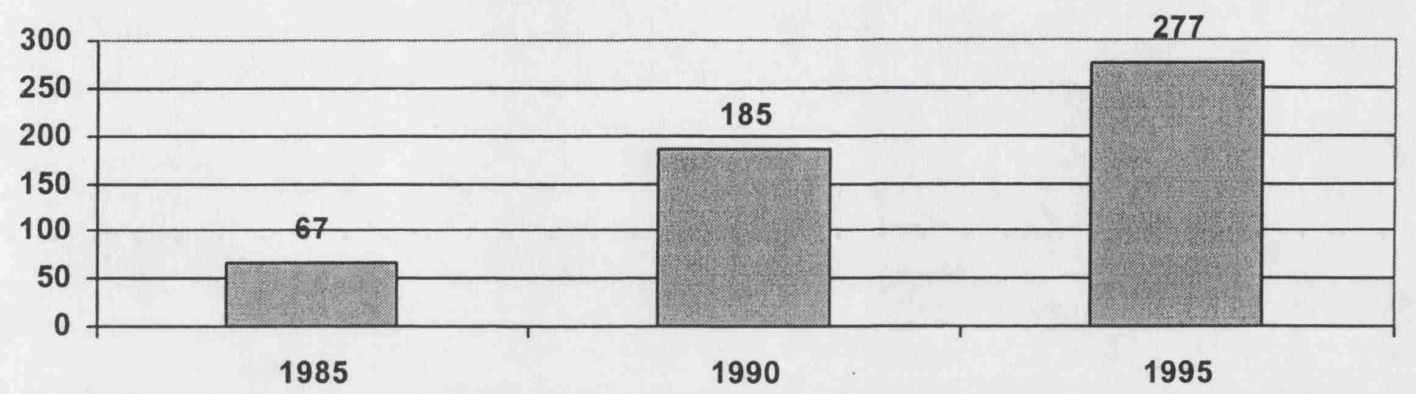

Source: (Colburn and Sánchez, 2000: 48)

As the graph above indicates, tourism is also a sector of significant growth. ${ }^{98}$ Like the other sectors of economic growth, tourism is associated with the development of a particular infrastructure. Tourism exceeds maquila production in earnings, and like non-traditional exports is understood in terms of a niche market. Tourism reflects a particularly vivid manifestation of neoliberal subjectivity in the post-counterinsurgent moment: as the niche market it relies on Guatemala's indigenous population and in so doing it also becomes a site of construction of the 'Sanctioned Maya'.

The relationship of the indigenous to tourism in the post-conflict state is explored further in Chapter 4. However, here it is interesting to note how the tourism niche is understood by economic elites. Colburn and S ánchez describe their interviews with business leaders in the region: 'In Guatemala, they speak of the necessity of utilising in a more aggressive manner not only their natural riches but their historical patrimony, such as the city of Antigua Guatemala and the Mayan ruins' (Colburn and Sánchez,

${ }^{98}$ Similar figures can be found in IMF, 'Guatemala: Recent Economic Developments', (Washington, DC: International Monetary Fund, 1998), 105-6. 
2000: 79, translation mine). This view reflects the desire for the 'Sanctioned Maya' in its emphasis on the ancient past and the colonial capital of Central America as expressions of $\mathrm{G}$ uatemala's $\mathrm{n}$ iche $\mathrm{m}$ arket. Like the d ehistoricized $\mathrm{M}$ aya constructed under counterinsurgency, tourism desires an understanding of the 'historical patrimony' of the nation as including an indigenous element from the irrecoverable past, superseded by the colonial project.

\section{The national economy as the firm}

The sectors noted above - banking, non-traditional exports, maquila, tourism - are taken up by CACIF as 'clusters' for national economic development. CACIF's understanding of the post-conflict state is constructed through a long standing conduit of intellectual and moral leadership in the form of the organization INCAE. ${ }^{99}$ INCAE is a business and management school begun by George Cabot Lodge, then at the Harvard Business School, in conjunction with Walter Rostow in the context of John F. Kennedy's Alliance for Progress (Lodge, 1999). ${ }^{100}$ While the establishment and conduct of INCAE is an interesting phenomenon in itself, the point of intellectual and moral leadership of interest here involves the adoption of a credible theory of national development that appeals both to CACIF's evolving economic interests, to the IFIs, and to the World Bank.

99 José Pivaral, interview, 3 April 2001. Pivaral noted that CACIF relies on INCAE for much of its macroeconomic analyses.

${ }^{100}$ It is interesting to note the other places Lodge established / oversaw management schools: Philippines, India, Turkey, and later Iran. 
Michael P orter's theory of The Competitive Advantage of Nations p lays this role. ${ }^{101}$ This theory provides an account of the national economy that is extrapolated from the experience of the firm. The role of the state is to provide the infrastructure for productivity and competition. The state's regulatory functions involve establishing market mechanisms and social investment is not for social ends per se, but for factors of productions (which, through the success of the firm, should ultimately lead to social ends).

Porter aims to 'move beyond comparative advantage to the competitive advantage of a nation' (Porter, 1990: 85). He understands competitiveness as productivity ('the only meaningful c oncept of competitiveness at the n ational l evel is p roductivity' (Porter, 1990: 84)). Productivity in turn is seen as constructed by the nation: 'a nation does not inherit but instead creates the most important factors of production - such as skilled human resources or a scientific base' (Porter, 1990: 78). This move from the comparative advantage to competitive advantage involves understanding the nation not as a given economic resource base, but as a constructed economy. It is an economy whose logic is assembled around the success of the firm.

The theory of The Competitive Advantage of Nations advocates government action in favour of the firm in the name of international competitiveness. It proposes a particular form of government assistance to firms but one that, unlike the proscriptions of Import Substitution Industrialisation, maintains a central role for the market in national

101 Gustavo Rodriguez, interview, 4 April 2001. See also: Michael E. Porter, 'Competitiveness in Central America', in Competitiveness in Central America: Preparing Companies for Globalization, ed. INCAE (San Jose, Costa Rica: Latin American Center for Competitiveness and Sustainable Development, 1996), as discussed below. 
development. Porter argues that government can play a 'legitimate' role in 'shaping the context and institutional structure surrounding companies and in creating an environment that stimulates companies to gain competitive advantage' (Porter, 1990: 86). Government, therefore, should play 'an indirect, rather than a direct, role' (Porter, 1990: 86). He suggests that 'industry will seek - and benefit from - more constructive forms of government support, such as assistance in opening foreign markets, as well as investments in focused educational institutions or other specialized factors' (Porter, 1990: 83).

This paradigm of the international economy is described as 'The Era of Total Competition' (Porter, 1996: 63). One strategy to take advantage of the opportunities afforded by the globalised international economy involves the creation of 'clusters' of related industries. By creating a network of local suppliers, clusters allow productivity to increase throughout the production cycle thus improving international competitiveness (Porter, 1996: 95-99). The role of government is to promote this process: 'The new business role of the nation is to serve as the home base for implementing regional and global strategies - for industries and clusters' (Porter, 1996: 105). Again, here 'factor conditions mean not just labor and natural resources, but a whole range of attendant areas: transportation, communications, information, education, the legal and judicial system, taxation, capital markets and so forth' (Porter, 1996: 105).

Porter's proscriptions for Central American firms involve learning to compete domestically and internationally with foreign firms. The rationale for this is that even in protected Central American economies, foreign firms are able to compete with local firms: Porter argues that Central American states have to be involved in constructing 
the terrain for this competition. In other words, governments need to create a climate of stability: 'There will always be disagreements on social policy, but everyone should agree on competitiveness and the value of productivity g rowth. The biggest sign of economic health is often how small the differences are between the opposition and the ruling party on economic issues' (Porter, 1996: 115). Governments should also provide 'basic inputs' - schools, roads, communication networks, even if it relies on the private sector actually to deliver them - and the proper regulatory environment: 'Governments must create a context that fosters innovation and upgrading. Antitrust laws and intellectual property protection are part of this' (Porter, 1996: 115). Finally, the government should reinforce the development of clusters 'by building infrastructure, increasing technical training, aiding research, and providing incentives to invest' (Porter, 1996: 115).

Understanding the national economy as the firm authorises the creation of economic infrastructure while preserving the role of the market in development. It technocratically structures government investment towards developing factors of production rather than understanding government spending as social investment subject to participatory democratic decision-making. In this sense, the logic of the Competitive Advantage of Nations continues that of the liberal modernisation project begun under the counterinsurgent moment.

\section{The new terrain of civil society}

As the economy became more 'transnationalised', so did civil society. The new 'modernised' form of civil society r eplicates the Western NGO, which is supported through international funding. 
External actors and local elites have actively participated in constructing 'civil society' in a particular image. Peter Sollis argues that in Guatemala the government was directly involved in NGO creation, particularly to promote micro-enterprise programmes. 'Mindful of the creative force represented by grass roots, political elites have devised a two-part strategy. While encouraging the arrival of US pentecostal church agencies, they have also organised their own NGOs' (Sollis, 1995: 534). These organisations reflect the coincidence of cultural destruction of the rationalities of liberal economics and counterinsurgency.

As Sollis notes, 'The scale of NGO funding questions the stereotype of NGOs as small players in Central America's unfolding drama. Hard data on funding is hard to gather because of the large number of funding sources, but estimates put the annual level of funding at o ver $\$ 200$ million a nnually at the end of the 1980s' (Sollis, 1995: 527). Jenny Pearce notes that donor preferences have marginalised the more 'political' and less 'technocratic' NGOs, or subjected them to 'capacity-building' programmes (Pearce, 1998: 612). She argues:

Most donors prefer the NGO as their model of a civil society organization, and many are engaged in turning organizations once seen as social empowerers into technical service deliverers and advocacy organizations on behalf of the poor. Words such as 'empowerment' and 'participation' are still used, but their meanings have become more anodyne and less political (Pearce, 1998: 613).

And she reminds us that 'associationalism' did exist prior to the 1980s, but was much less dependent on outside funding (Pearce, 1998: 613).

The promotion of evangelical churches is an interesting example and one that, perhaps not surprisingly, involves a strong US dimension. The number of evangelical Protestants in Guatemala increased from three to 25 percent of the population in the 
period 1960-90, giving it the most Protestants of any Latin American country (Rose and Brouwer, 1990: 43). ${ }^{102}$ In the words of the Project for Historical Memory:

The army encouraged these sects as a way of controlling the population. The sects broadcast their own version of the violence and blamed the victims. They advocated structural changes in the religious life of the communities based on separation into small groups, messages legitimizing the army's power, and individual salvation. Their ceremonies involved mass emotional catharsis. Violence thus became the motivating force behind these evangelical sects, which installed themselves throughout much of the country (Human Rights Office of the Archdiocese of Guatemala, 1999: 47). ${ }^{103}$

Rios Montt, who governed in the second half of the counterinsurgency (1981-83) was indeed a member of a California-based evangelical church, the Church of the Word $(E l$ Verbo, in Guatemala). The rhetoric of the church - vehemently anticommunist informed the counterinsurgency campaign, which became known as his 'holy war against communism in the highlands' (Rose and Brouwer, 1990: 47). It is interesting to observe that while the army justified its punishment of the people with the claim that the guerrillas had deceived them, ' $[\mathrm{t}]$ he punishment is sometimes referred to by the displaced as "the judgement" (el jucio), a reference to the Bible which legitimizes the punishment as an act of paternal authority' (Stepputat, 1999: 71-72). Elites accepted evangelical churches because of their promulgation of 'individual salvation rather than group solidarity and disciplined work under sanctioned authority' (Rose and Brouwer, 1990: 44).

Much of the impetus, materials, organisation, and funding for evangelical churches in Guatemala have come from the US and are 'perceived by many Guatemalans as being

${ }^{102}$ For a study of religious divisions in Guatemala and their economic significance from an anthropological perspective, see: Sheldon Annis, God and Production in a Guatemalan Town (Austin: University of Texas Press, 1987).

${ }^{103}$ The RHEMI report is admittedly sponsored by the Catholic Church, which has itself been divided between conservatives and liberation theologians throughout the war. 
an innovative, modern product from North America' (Rose and Brouwer, 1990: 44). Evangelical schools, which provide free, private education, have been particularly successful in Guatemala, where public education only reaches 60 per cent of students (Rose and Brouwer, 1990: 50-52). ${ }^{104}$ Susan D. Rose and Steve Brouwer describe the educational materials associated with these churches: they strongly support free enterprise and condemn communism as the work of Satan, characterise the fight against communism as a religious one, promote private property (and suggest that Mayans' failure to embrace private property - their poor 'stewardship' of the land - is why they have been dispossessed), and argue that poverty is the result of laziness and lack of discipline. ${ }^{105}$ Unlike Acción Católica, for example, a developmentalist political agenda does not accompany the proselytising of evangelical churches: they explicitly oppose public health-care clinics and peasants' cooperatives (Rose and Brouwer, 1990: 52).

In sum, the terrain of civic participation has been strongly shaped by the effects of war, whether through direct repression or through its social and psychological impacts. External actors have been able to influence the fragile social and economic conditions through the provision of finances, 'expertise', and educational opportunity.

${ }^{104}$ In fact, public education reaches 75 percent of students aged 7-14 in urban areas and 34 percent in rural areas.

${ }^{105}$ In a comic but disturbing passage, they note that one pamphlet wrongly quotes Stalin as having advised people to "undermine the loyalty of citizens in general, and young people in particular, by making it easy for them to obtain drugs of all kinds, giving them alcohol, extolling their savagery, and strangling them with sexual literature"'. Susan D. Rose and Steve Brouwer, 'The Export of Fundamentalist Americanism: US Evangelical Education in Guatemala', Latin American Perspectives 17, no. 4 (1990): 45. 


\section{Ethnic identity versus ciass identity}

Class divisions have existed within Indian society since the 19th century if not earlier, when an Indian bourgeoisie emerged in the Western highland city of Quezaltenango (Grandin, 2000). However, a broader phenomenon of the emergence of an indigenous bourgeoisie follows the agricultural modernisation programmes from the 1960s. As Greg Grandin notes, in the period 1950-75,

While many Mayans, perhaps a majority, sought seasonal employment on coastal plantations to supplement their shrinking milpas (corn plots), a significant number of Indian stepped up their nonsubsistence economic activities, such as labour recruitment, commerce, manufacturing, and specialized agricultural production. Studies conducted at this time describe increased social stratification and capital accumulation within communities (Grandin, 1997: 10-11).

He underscores that although this period represents an intensification of land and other economic pressures, 'members of this new indigenous bourgeoisie usually emerged from the same hierarchical networks that for centuries had generated community leadership' (Grandin, 1997: 11-12). Nonetheless, these factions did struggle in 'intellectual and moral leadership' for the political leadership of indigenous communities. In the 1960s the contest was between the bearers of traditional authority 'costumbristas' and the commercial sector / bourgeoisie associated with Acción Católica while by the mid-1970s radicalized Indian campesinos who rejected both claims to authority joined the debate (Arias, 1990: 251).

The counterinsurgent moment generated an 'ethnicisation' of popular politics, in putting ethnic identity at the centre of the conflict. However, while from the criollo/ladino perspective the indigenous population might seem like an undifferentiated mass of 'Indians', the Maya in Guatemala actually involve 23 distinct linguistic groups where political consciousness historically was local rather 'panMayan'. Indeed, popular organising would need to overcome these language barriers; 
figures such as Rigoberta Menchú have commented on the irony of relying on the colonial language to defend indigenous culture because of the difficulties of organising in any other way. The CUC's initial success involved its class-based analysis, which attracted both Indians and poor ladinos. However, the CUC did develop materials specifically to mobilise Indians into the political struggle. The Declaración of Iximché was the product of CUC consultation with Indian leaders on the plight of the indigenous. It concluded with a phrase from one of the foundational Mayan stories, the Popol Vuh, which became a slogan for popular organising - 'That all arise, that all be called. That there be neither one nor two groups among us who remain behind the rest!' (Arias, 1990: 254). From this point, and in response to the comprehensive militarisation of the highlands, many indigenous groups joined the guerrilla.

The appeal to ethnicity opened up the debate as to what the nature of the (pan-) Mayan' identity involved, and whether discrimination should be considered predominantly in terms of race or class. Grandin observes, 'A closer examination of the 1 anguage of the p opular and r evolutionary movement r eveals a c ultural s truggle being waged not simply in the contested zone separating ladinos and Indians but within the ideological boundaries that mark the essence of what it means to be Mayan.' (Grandin, 1997: 12-13). Arias also describes the challenges of this move:

Ethnic identity has been transformed in the search for political force. Now, identity was a tangible, verbalized, phenomenon, around which the articulation of political practices was sought. But the symbolic practices, the worldview, and the unconscious codes had been discarded without the formation of new ones to substitute for them. Thus, in concrete practice, just as identity was being talked about more openly, it was experiencing its deepest crisis (Arias, 1990: 251).

The CUC forged a pan-Mayan identity with 'elements of liberation theology, marxism and Guatemalan nationalism' (Grandin, 1997: 21-22). However, other movements 
would seek to define ethnicity in terms that excluded class and preserved the Indian bourgeoisie (Arias, 1990: 252-3). Deborah Yashar argues that Mayan nationalist groups are 'smaller and more middle-class than ... the popular organizations - which at times has created tensions on all sides about more authentic representation and debates over whose interests are being promoted by the respective organizations' (Yashar, 1997: 254). A genuine concern for issues of ethnicity and gender did enter the expressed concerns of the 'traditional "popular"- (i.e., class-) based organizations' (Yashar, 1997: 254). However, as the conflict progressed, the nature of organising moved away from calls for material changes to questions of human and civil rights (Yashar, 1997: 253).

Moreover, external support proved more amenable to 'Indian rights' than 'peasant rights' or armed resistance. Grandin suggests, 'as the repression mounted and the rebels lost ground, class-based Mayanism has increasingly sought legitimation by presenting the struggle in cultural terms, supported by increasing international attention to indigenous rights' (Grandin, 2000: 25). The new generation of 'postcounterinsurgency community leadership ... notably avoids directly addressing social problems such as land shortage or endemic poverty' (Grandin, 2000: 25). Ultimately, the 'classless' Indigenous identity would win out in the peace negotiations.

\section{Conclusion}

Reading the Guatemalan ensemble of social relations through the lens of disarticulation brings into relief particular tensions that characterise its historical and material construction over time. These tensions are related to an evolving problematic 
of liberal modernisation: race, force, the relationship between public and private, and the nature of peripheral capitalism's incorporation into the international economy.

The expansion of coffee agriculture, with its particular labour requirements and geography, institutionalised race and coercive labour practices as a dimension of disarticulation. The vulnerability of coffee production to international economic conditions and the resultant introduction of US-based multinational capital into the Guatemala, in part associated with a genuine attraction to US-style modernisation, reflect the objective and subjective international dimension of disarticulation. The modernising ethos persistently, both 'internationally' and 'domestically', involved the subjective construction of race hierarchies as part of their understandings of advanced / developed and backwards / traditional. The nationalist-capitalist backlash against the contradictions generated in by the expansion and intensification of disarticulation mitigated its worst effects materially, by offering to change the economic mode of production for the most marginalised. Yet its project was limited and did not incorporate domestic elites, whose perception of modernisation (indeed a matter of internal division) still lay with international markets and finance, not with the extension of small scale capitalism and the creation of local markets. Counterinsurgency becomes the manner in which a coalition of elite interests reverses the reforms that threatened to undermine the bases of disarticulation locally and in terms of Guatemala's relationship into the international political-economy.

Under the reconstruction of disarticulation through counterinsurgency, the ensemble of social relations becomes modified economically, socially, and subjectively. Economically, the material bases for a new understanding of modernisation develops with the expansion of banking and finance, non-traditional agriculture, maquila, and 
tourism. Socially, key elements of civil society - the voluntary sector and religion are each transformed into new understandings of the ensemble of social relations, which privilege international understanding of depoliticised, technical strategies of development on the one hand and the atomised entrepreneur on the other. Similarly, the social effects of counterinsurgency reconstructs the Mayan identity in a sanctioned form: classless, atomised, and for which culture must be understood through a narrow conception of rights rather than a fuller understanding involving questions of its political-social-economic bases. These transformations occur initially through US involvement in the post-coup state, but evolve with the global historical bloc to become increasingly 'neoliberal' from the 1970s.

Understanding these modifications of the ensemble of social relations (ever informed by residual 'common sense' understandings), particularly in the counterinsurgent moment preceding the peace process, is important for understanding the perspectives of different groups entering the negotiations, how their goals are constructed, what is seen to be legitimate terrain for compromise. It is to the peace process that the next chapter turns. 


\section{The Peace Process}

As per the Gramscian framework outlined in Chapter 2, Chapter 3 described the ensemble of social relations in Guatemala, the construction of the disarticulated, counterinsurgent state, and the emerging crisis of the counterinsurgent state under the logic of a neoliberal world order. This chapter examines the peace process as a resolution to that crisis and its project of reconstructing a neoliberal state through the post-conflict reconstruction plans articulated in the text of the accords.

The counterinsurgent state suffers from internal contradictions that generate such repression as to become unwieldy for neoliberalism, largely in the lack of security for capital associated with a military unaccountable to economic elites and a rapidly expanding debt. The Guatemalan peace process follows directly on a domestic effort at 'democratisation' that preserves a certain set of social relations, essentially involving economic elites re-subordinating the military, and a regional/international effort to control the excesses of Reagan's late Cold War policies in the region, associated with economic elites' endeavours to improve their international standing for finance and development. These conditions establish certain parameters for the Guatemalan peace process, particularly vis-à-vis understandings of democratisation and the need to rebuild civil society.

This discussion, then, has much in common with William I. Robinson's arguments about the authoritarian-democratic transitions. He suggests that authoritarian regimes became seen as inefficient for political stability as globalisation generated widespread democratisation movements. The response of the US, acting on behalf of a transnational elite, was to co-opt the idea of democracy called for by such movements, 
defining it in terms of 'polyarchy' where 'a small group actually rules and mass participation in decision-making is confined to leadership choice in elections carefully managed by competing elites' (Robinson, 1996: 49), and to emphasise political intervention into civil society to reconstruct it as an arena to buttress elite political projects (Robinson, 1996: 28-29).

However, as discussed in Chapter 2, the analysis here differs from Robinson's in its understanding of power and the ultimately related concern of agency in international relations. Thus, while the Guatemalan case does indeed support the idea that a 'polyarchic' definition of democracy was at work, this was established through Guatemalan elites' control of the return to civilian rule and through the multilateral negotiations of the regional peace processes of the 1980s. Likewise, the notion of the need to (re)build civil society as a reflection of the 'political centre' was constructed through multilateral negotiations. This is not to say that the intellectual and moral leadership within the US r egarding the understanding of d emocratisation within the context of polyarchy that Robinson describes was not influential in constructing polyarchy internationally: merely that it should not be associated exclusively with the agency of the United States. ${ }^{106}$ Rather, 'common sense' understandings of both democracy and civil society become established through international processes of consensus-building around certain international problems.

106 Robinson particularly analyses 'two of the most widely cited and circulated volumes [in the US]' - Transitions from Authoritarian Rule: Prospects for Democracy, edited by Guillermo O'Donnell, Phillippe C. Schmitter, and Laurence Whitehead and Democracy in Developing Countries, edited by Diamond, Larry, Jonathan Hartlyn, Juan J. Linz, and Seymour Martin Lipset - as commissioned with the intent of informing US policy on democratisation Robinson, Promoting Polyarchy: Globalization, US Intervention, and Hegemony, 45 
Indeed, the analysis offered here finds Robinson's description of the technologies for managing authoritarian-democratic transitions that comes the US democratisation literature very apropos. A successor to theories of political development (those central to counterinsurgency, as per Chapter 3), this literature likewise relies on the reification of order in the social sciences as the key political 'good' (Robinson, 1996: 46-48). It restricts deeper definitions of democracy in the name of avoiding a regression to authoritarianism: 'Popular forces have to be restrained in order to assure a stable transition, and are held responsible for jeopardizing "democracy" by inducing with their social demands a resurgence of authoritarianism' (Robinson, 1996: 64). Elections are a key legitimating feature of this system, yet the undemocratic nature (indeed purpose) of elections is explicit; according to O'Donnell and Schmitter, 'put in a nutshell, parties of the Right-Center and Right must be "helped" to do well, and parties to the Left-Center and Left should not win by an overwhelming majority' (Robinson, 1996: 65). Furthermore, (Robinson, 1996: 64)the requirement for orderly transitions leads to trade-offs between popular demands and the promise of participation in the consolidated, post-transition 'democracy' in two areas: the economy and the military. However, such trade-offs are not - as they are cast - temporary, transitional concessions; rather, they become structural features of the post-transition order (Robinson, 1996: 65). The Guatemalan peace process similarly u sed elections in an unreformed system to legitimate the negotiations and engaged in a number of strategic deferrals of essential issues, as discussed further below.

The impuise to engage in the peace process reflects the global order, however not merely in terms of neoliberal regimes of production, but the end of the Cold War, which changes the logic of the 'revolutionary option'. This development affects the relationship between industrialised and developing countries, it is implicated in the 
constuction of the 'common sense' understanding within industrialised countries, their solidarity support, and the attraction of a negotiated settlement to both sides of the conflict for different reasons. This chapter explores the conditions leading to the Guatemalan peace process, the negotiations themselves, and the post-conflict state as articulated in the peace agreements through a Gramscian lens sensitive to the opportunities and limitations regarding progressive social change in such circumstances.

These stages of the peace process each can be understood through the constituent elements of Gramscian politics: the construction of 'common sense' understandings of democracy and civil society through the regional peace processes of the 1980 s, intellectual and moral leadership associated with the agenda setting phase of the negotiations that disciplined the guerrilla with the 'end of the revolutionary option', and the use of civil society to legitimise the peace process under the period of UN conciliation. The negotiations also engaged in deferral strategies for postponing discussion of the 'essential', leaving economic and military issues to a particularly undemocratic end-game, the result of which can best be understood in terms of the Gramscian conception of caesarism.

As discussed in Chapter 2, caesarism reflects a limited or 'passive' form of hegemony, manifest in 'autonomisation' of the bureaucracy and trasformismo, where the opposition is co-opted into the establishment (Forgacs, 1988: 248). Caesarism occurs where the integral state lacks the institutional framework for the 'deeper' hegemony possible in advanced liberal democracies; in Italy, caesarism was manifest both in the 'parliamentary dictatorships' that precede fascism and fascism itself (Gramsci, 1991: 227-8). As David Forgacs observes, 'in treating Fascism as a form of Caesarism and of 
“revolution-restoration", Gramsci illuminates its novel and dynamic character' (Forgacs, 1988: 248, emphasis original). In Guatemala the consensus around the peace agreements would be somewhat 'unstable' (always a feature of caesarism in its initial stages); the novelty of its 'revolution-restoration' as an attempt to resolve the contradictions of counterinsurgent disarticulation would involve the modernising private sector, brought to government in the 1995 elections, brokering agreements over the deferred 'essential' with the URNG with the active involvement of the international community.

The blueprints for the post-conflict state that emerge from this process (re)construct the neoliberal state and subject. As the textual analysis of the accords in the final section of this chapter illustrates, the accords not only construct neoliberalism in its more conventional guises - subjecting its marginal land redistribution to market mechanisms, for example - but also by framing citizenship in terms of economic agency and through the construction of a neoliberal homo economicus, as discussed in Chapter 2. The power of dominant interests is maintained through the preservation of coercion, which is 'relocated' objectively - through a transition from the military to police - and subjectively, though the persistence of impunity.

\section{The crisis of the counterinsurgent state}

Chapter 3 described the disarticulated ensemble of social relations constructed through the post-reform era in Guatemala. This order was established and maintained through a counterinsurgent state, which embodied a number of tensions in its mission of securing and reconstructing society. Counterinsurgency tries to eliminate the marginalised elements of society produced by social disarticulation through coercive reconstruction 
or genocide. Yet this fundamental antagonism of needing to secure a social order that is assumed yet does not exist forces counterinsurgency into a continual obfuscation of public and private to avoid exposing its contradictions while justifying its need for dramatic social control. Counterinsurgency requires continuous management in its movement between articulating the ontological threat to the body politic and obscuring the organic, self-produced nature of that threat, i.e., that the threat that has been identified is integral to and produced by the body politic itself.

The return to civilian government in 1986 can be read as a readjustment of counterinsurgency necessitated by its own contradictions: it involved both a prior securitisation through the intensification of the military campaign, yet, at the same time, this securitisation process exposed the contradictions of counterinsurgency and put the more fundamental question of disarticulated modernisation at risk through its economic policies and by compromising access to international markets and finance. ${ }^{107}$ The move to formal civilian 'democracy' provided only a slight, highly controlled political opening that in fact legalised certain elements of the counterinsurgency in a new constitution. In a small move towards 'consensual' governance, the coercive apparatus of society was maintained.

The return to civilian government in Guatemala begins in the late 1970s and 1980s. Military mismanagement and corruption in the 1970 s had alienated junior officers and much of the organised private sector (McCleary, 1999: 41). The Guatemalan economy

107 The emphasis in the literature on the return to civilian rule illustrates the great normative purchase of the idea parliamentary democracy. Guatemala's previous civilian government was elected in 1970. In the reading offered here, then, this reification of 'democratisation' reflects a liberal democratic reaction that assumes that elections would inherently be sufficient to end counterinsurgency. 
deteriorated rapidly in the late 1970s and early 1980s: the foreign debt (previously the second lowest in Latin America) tripled, financed by short-term, high-interest loans: the payments by the mid-1980s amounted to 40 percent of the total value of exports (Moreno, 1994: 45). By 1982, the tensions had become particularly pronounced: internationally, Guatemala had become a pariah (even the Reagan State Department had referred to the regime as 'a bunch of thugs' (Trudeau, 1993: 47)), junior officers felt the military leadership was out of touch with the realities of the counterinsurgency that had been escalated in 1981, and economic elites were being asked to pay for the intensified military campaign while officers themselves profited through graft (McCleary, 1999: 45-47).

These tensions led to two coups in the early 1980 s - General José Efraín Ríos Montt in 1982 and General Oscar Humberto Mejía Víctores in 1983 - inspired by a 'reformist' ethos, albeit a sense of reform that included military victory over the insurgency as part of its agenda. Ríos Montt was initially viewed as someone who would resubordinate the military to e conomic e lites, a though he s oon o verstepped $\mathrm{h}$ is $\mathrm{r}$ emit with an independent (and evangelical) sense of modernisation that alienated the private sector (Trudeau, $1993: 60-3) ;($ McCleary, $1999: 55) .{ }^{108} \mathrm{He}$ i nitiated a programme to prepare Guatemala for new elections, though his comprehensive reorganisation of the requirements for political parties weakened established political parties under 'the

${ }^{108}$ Ríos Montt was Guatemala's first evangelical president. For a discussion of the relationship between his faith and his presidency, see: David Stoll, Is Latin America Turning Protestant? The Politics of Evangelical Growth (Berkeley: University of California Press, 1990), Chapter 7. Rachel McCleary notes that 'Ríos Montt preached on Sunday radio as part of his "New Guatemala" propaganda campaign. He used the opportunity to preach moral values, but he also aired publicly his differences with the private sector and other with whom he was not in agreement'. Rachel M. McCleary, Dictating Democracy: Guatemala and the End of Violent Revolution (Gainesville, FL: University Press of Florida, 1999), 55. 
half-true rationale that the party system needed to be opened up' (Trudeau, 1993: 61). ${ }^{109}$ Ríos Montt further alienated himself from economic elites in his declaration that he would serve additional time in office (to compensate for the electoral fraud perpetrated by his predecessor) and in his fiscal policy which marginalised CACIF (McCleary, 1999: 52-55). He also lacked a strong base in the military, relying on a young junta for his support (McCleary, 1999: 55). Thus, the military viewed the coup to replace him as a corrective to continue the basic principles of counterinsurgent 'reform': “"The message was right, but the messenger [Ríos Montt] was wrong"” (McCleary, 1999: 55-56, quoting: Francisco Beltranena). ${ }^{110}$

Under Mejía Víctores, Ríos Montt's plans for a National Constituent Assembly tasked with drafting a new constitution were realised in July 1984 elections. The new constitution, drafted a year later, included greater scope for political organising, although it followed on an amnesty (covering the years 1982-86) that significantly insulated the armed forces (Dunkerley and Sieder, 1996: 83). The provisions of new constitution facilitated the formation of p olitical $p$ arties, r ecognised the $m$ ulti-ethnic nature of the Guatemalan state, and created new offices such as those of the Human Rights Ombudsman and the Constitutional Court (Azpuru, 1999: 102). However, it also legalised the institutions of counterinsurgency such as civil patrols (PACs), model villages, and the coordinating councils that subordinated development projects to military command (Dunkerley and Sieder, 1996: 83). Jennifer Schirmer argues that military officers were aware of 'ingenuity' of 'immersing counterinsurgency structures

109 Continued repression meant that there was not a significant opposition in the elections of 1984 and 1985. R obert H. Trudeau, Guatemalan Politics: The Popular Struggle for Democracy (Boulder: Lynne Rienner, 1993), 69.

${ }^{110}$ Francisco Beltranena was a founder and board member of the military's Centro de Estudios Estratégicos para la Estabilidad Nacional (Centro ESTNA). 
within the 1985 constitution written by the National Constituent Assembly' (Schirmer, 1998: 77). As Robert H. Trudeau observes, 'Each of these changes reduced the need for open military repression, while at the same time providing the appearance of new levels of popular participation and democracy' (Trudeau, 1993: 66).

The less frequently noted 'national discussion' of the Mejía Víctores regime took place between economic elites - CACIF - and the military. ${ }^{111}$ As the early 1980 s saw the tensions in the contradictions of military rule bring elite pressures for reform, CACIF reorganised to enhance its capacity to affect government policy: this restructuring was led by 'a younger generation of entrepreneurs' who valued neoliberalism (McCleary, 1999: 57). Restructuring initially alienated traditional agricultural elites, but they returned to CACIF in 1985 in the context of National Commerce Commission negotiations between CACIF and the government on the implementation of a September 1983 IMF credit agreement (McCleary, 1999: 60-1). ${ }^{112}$ CACIF was able to pressure the resignation of both the minister of finance and the minister of economy of

111 This account relies on Rachel McCleary's detailed examination of CACIF, although it disagrees with the normative nature of her assessment that capitalism promoted 'democratisation', given the elitist definition of democracy that it relies upon. Nonetheless, such c laims expose the influence of the p rivate sector, which is illuminating. McCleary, Dictating Democracy: Guatemala and the End of Violent Revolution. For a discussion of how such elite-oriented theories rely on the separation of the political and the economic to justify economic inequalities, only to later reunite them with claims about the affinities between capitalism and democracy, see Robinson, Promoting Polyarchy: Globalization, US Intervention, and Hegemony, 5256.

${ }^{112}$ Indeed, at this point CACIF was able to consolidate virtually all of the 'organised private sector, incorporating previously independent USAID organisations'. McCleary, Dictating Democracy: Guatemala and the End of Violent Revolution, 58. The Commerce Commission was a public-private forum called at the behest of CACIF. The suspension of the IMF agreement, among other consequences, led to an acrimonious debate about the source of inflation in Guatemala: the government blaming it on capital flight and the private sector blaming it on corrupt government and debt. McCleary, Dictating Democracy: Guatemala and the End of Violent Revolution, 61. 
the Mejía Víctores government, in part through organising in a work stoppage that involved government officials (McCleary, 1999: 61). Ultimately, this confrontation between the government and CACIF was resolved through a 'National Dialogue' (that also included some labour representation) in late April 1985, which consolidated CACIF's policy-making prowess:

CACIF successfully had asserted it control over fiscal and economic policy. It had become the crisis negotiator par excellence and would remain the main defense instrument for the private sector. No administration henceforth could enact into law a bill relating to the economic and fiscal aspects of the country without negotiating beforehand with CACIF (McCleary, 1999: 62).

This political victory reflected neoliberal economic principles, which CACIF supported both because of the 'organic' composition of its reconstructed leadership and because of the related issue of the international economic environment of the day. ${ }^{113}$

The elections of 1986, although 'procedurally correct', remained a contest of the right/centre-right and were notable for their absence of discussion of both military accountability - corruption or human rights abuses - and socio-economic reform (Trudeau, 1993: 69-71). According to Robert Trudeau, both the army and CACIF 'made clear that they would not tolerate reform proposals after the inauguration' (Trudeau, 1993: 71). Vinicio Cerezo, a Christian Democrat, won, having cultivated the support of CACIF with commitments to its economic agenda, promises not to introduce land reform, and his concern for policies that might provoke capital flight (Dunkerley, 1990: 249, Dunkerley, 1988: 501). These elections were widely seen as

${ }^{113}$ For example, Guatemala's modernising elites were keen to take advantage of the US-led Caribbean Basin Initiative (which emphasised non-traditional exports), in addition to the pressures of international creditors, who emphasised the liberalisation of markets and export led growth. McCleary, Dictating Democracy: Guatemala and the End of Violent Revolution, 50-51, 63. 
motivated by the need to i mprove Guatemala's image internationally on the related fronts of human rights abuses and the need for sufficient legitimacy to attract international finance.

The return to civilian rule was accompanied by a constitution that protects the military and the reassertion of private sector elites' control over economic policy. The constitution would later serve as the foundation for the peace process and the elections that would endorse it. This 'democratisation' process informed Guatemalan participation in regional peace processes (similarly motivated by improving its international image), which would lead to the national dialogue and the peace process.

\section{Regional peace processes}

The Guatemalan national peace process follows on two regional peace processes, Contadora and Esquípulas, the latter of which is associated with Guatemala's civilian government's search for international legitimacy. These peace processes establish the international community in the r egion, and the possibility for addressing the 'social bases of conflict', however, within parameters dictated by efforts to secure the progressive Sandinista government in Nicaragua.

\section{Contadora}

The first efforts at regional peace-building in Central America occur through the Contadora Process in 1983, an initiative of Mexico, Venezuela, Colombia and Panama to prevent the US, in the throes of the Reagan administration's aggressive regional foreign policies, from getting directly militarily involved in the Sandinista revolution 
in Nicaragua (Bagley, 1986: 2-3). ${ }^{114}$ A primary element of the Contadora initiative's attempt to mitigate US militarism involved actively redefining the conflicts as the result of internal considerations - poverty, injustice, repression - in contrast to the Reagan administration's claims of Soviet-Cuban subversion to understanding them (Bagley, 1986: 3); (Moreno, 1994: 56); (Aguilar Zinser, 1988: 101). ${ }^{15}$ Nonetheless, in the course of negotiations over the course of three years, ${ }^{116}$ the Contadora process emerged with a rather paradoxical emphasis on conflicts among states in the region, not those within them, a construction that could appeal to both extremes: the Sandinstas, who wished to eliminate Honduran and potentially Costa Rican support for the contras as well as the Salvadoran government under threat from the revolutionary Frente Farabundo Marti de Liberación Nacional (FMLN; (Aguilar Zinser, 1988: 103, $08) .{ }^{117}$

${ }^{114}$ See a lso: A dolofo A guilar Zinser, Negotiation in Conflict: Central A merica and Contadora', in Crisis in Central America: Regional Dynamics and US Policy in the 1980s, ed. Nora Hamilton, et al. (Boulder: Westview Press, 1988), and Dario Moreno, The Struggle for Peace in Central America (Gainsville: University of Florida Press, 1994), chapter 3. Moreno contains the main Contadora texts (communiqués and agreements) in English.

${ }^{115}$ The initiative remained, as Bruce Michael Bagley has observed, within distinctly 'moderate' parameters: 'the Contadora countries were also unanimous in their desire to moderate and contain the revolutionaries in Nicaragua and El Salvador'. Bruce Michael Bagley, 'Contadora: The Failure of Diplomacy', Journal of Interamerican Studies and World Affairs 28, no. 3 (1986): 3.

116 The Contadora process has been compared to a cat with nine lives because of its resilience despite what seemed like impossible set backs. Bagley, 'Contadora: The Failure of Diplomacy': 4. What seems clear is that at different points both the Sandinistas and the Reagan administration renewed their involvement in the process for diplomatically strategic reasons, in the Nicaraguan case to put Washington on the defensive and in the latter case often to appear to be working in good faith to the US Congress and thus justify greater aid to the contras.

${ }^{117}$ Similarly, references to foreign bases could imply either the US in Honduras and El Salvador or concerns about a Cuban / Soviet presence in Nicaragua. Aguilar Zinser, 'Negotiation in Conflict: Central America and Contadora', 108. 
The US participated in the Contadora process despite significant evidence that it would not accept the basic premise of recognising the Nicaraguan revolution in exchange for its 'containment' (Bagley, 1986: 22) ${ }^{118}$ Its objections were repeatedly framed in terms of questions of democracy and verification. The US responded to the first declaration of the process, the Cancún Communiqué, with the objection that 'only by ensuring free and open participation in the democratic process can the people of Central America achieve reconciliation within their societies' (Moreno, 1994: 59, quoting the Congressional Record, 15 May 1984: S5758). The Reagan administration reacted similarly to the accord on procedural norms with the statement that, in addition to the reduction of military forces and the end of ties to Cuba and support for the FMLN in El Salvador, the US wanted Nicaragua to "'permit democratic pluralism to flourish at home"' (Bagley, 1986: 8, quoting then Secretary of State George Schultz). Likewise, the Revised Act was met with the accusation that Nicaragua had rejected the key elements of that text relating to internal democratisation (Bagley, 1986: 8). (The Sandinistas' unexpected acceptance of the Revised Act put the Reagan administration on the defensive.) The notion of democratisation became integrated into the Contadora texts and would represent a significant norm in future regional initiatives. ${ }^{119}$

\footnotetext{
118 In addition to its continued support for the contras throughout the Contadora process, a n oft-cited example is the 1984 report of a commission chaired by Henry Kissinger that argued that Contadora was not necessarily in the US national interest and that "“force remains an ultimate recourse" of US policy' Bagley, 'Contadora: The Failure of Diplomacy': 7. See also: James Dunkerley, The Pacification of Central America (London: Institute of Latin American Studies, 1993), 37.

119 The purpose here is to describe the international dynamic of the regional peace processes, not to assess the Sandinista revolution per se. However, it bears observation that even by conventional, 'institutional' measures - such as a constitution protecting freedom of speech, assembly, movement, and the right to due process; the separation of powers; and regular elections - the Sandinistas had as strong a claim to democracy as several of its neighbours. Robinson, Promoting Polyarchy: Globalization, US Intervention, and Hegemony, 216.
} 
The European Community initiated an annual conference with the Central American governments, the San José dialogue, in 1984 to provide a forum to discuss economic assistance and support for the Contadora process (Whitehead, 1996: 233) (Biekart, 1999: 176). Initially, official European assistance often supported the Sandinista revolution; several Social Democratic governments (including Spain, Sweden, West Germany and France) responded to a call by the Socialist International for such support (Biekart, 1999: 175-6). European governments, in contrast to the US, understood the origins of the conflicts in terms of economic and social causes, however, after the early 1980s 'open European support for the Sandinista government became less clear-cut and shifted towards more "neutral" statements calling for the establishment of democratic principles and strict observance of human rights' (Biekart, 1999: 176).

A similar expansion and transformation can be observed in private European aid. Kees Biekart identifies four stages of European private aid activities in Central America: the arrival of such agencies in the early 1980s, their activities under counterinsurgency, their p olicy transitions a round the 1987 E squipulas II a greement and their interventions after 1989 (Biekart, 1999: 182). He argues there are several reasons for their significant growth, from a dozen prior to 1980 to over a hundred organisations by the late 1980s: support for the Sandinistas from progressive circles, the alternative they provided European governments to challenge discretely the Reagan administration, the larger trend in which European private aid agencies became increasingly significant in the international aid sector (Biekart, 1999: 182-4). ${ }^{120}$

${ }^{120}$ According to Biekart, 'Although exact figures are difficult to acquire, in 1987 the forty largest European private aid agencies channelled approximately US\$130 million to Central America, a figure that increased to almost US\$200 million in 1992. In 
Initially, private aid largely involved emergency assistance (Biekart, 1999: 206). However, the democratic transitions in the region 'generated confusion about the new "political agenda" of private aid agencies and fuelled concern that the "era of solidarity aid" had ended' (Biekart, 1999: 208). This development resulted in a new form of European private aid: 'Instead of popular education and institutional support for strengthening organisations in civil society, support shifted to management and training methods to strengthen the capacity of organisations in order to increase their likelihood of economic sustainability' (Biekart, 1999: 208). OECD figures for European and US bilateral assistance to the region over the period 1980-2000 are shown below, ${ }^{121}$ followed by multilateral aid figures for comparison.

Bilateral Aid $1980-1990$ in US\$ Millions

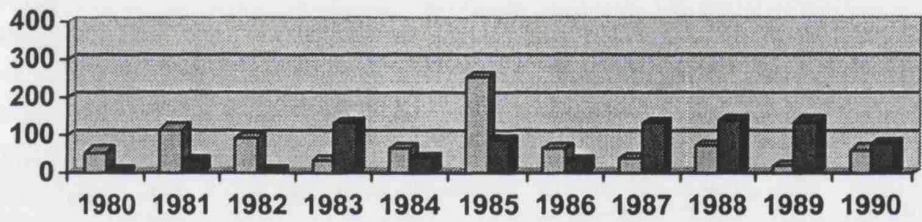

口Erope a US

relative terms this was about ten percent of total bilateral and multilateral aid flows to the region and more than forty percent of total bilateral aid flows to Central America of all the European governments combined'. Kees Biekart, The Politics of Civil Soceity Building: European Private Aid Agencies and Democratic Transitions in Central America (Utrecht: International Books, 1999), 182.

${ }^{121}$ European bilateral aid includes contributions from the following countries: Austria, Belgium, Denmark, Finland, France, Germany, Greece, Ireland, Italy, Luxembourg, the Netherlands, Norway, Portugal, Spain, Sweden, Switzerland, and the UK. These charts were calculated based on total net receipts. 


\section{Bilateral Aid 1991-2000 in US\$ Millions}

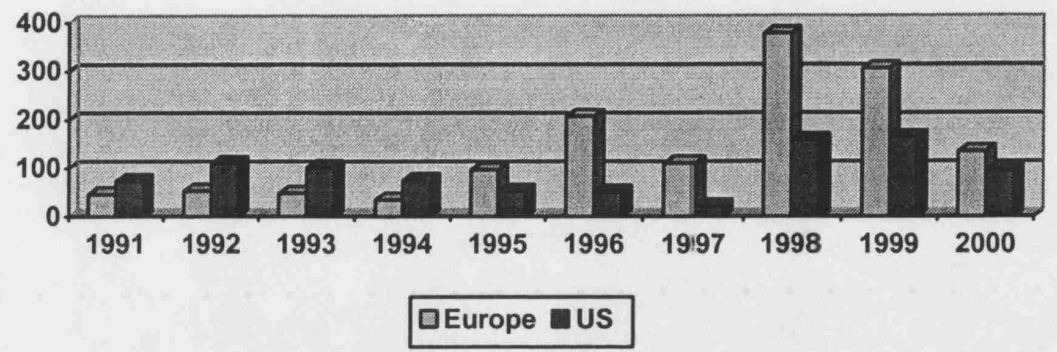

Source: (OECD)

Multilateral Aid 1980-1990 in US\$ Millions

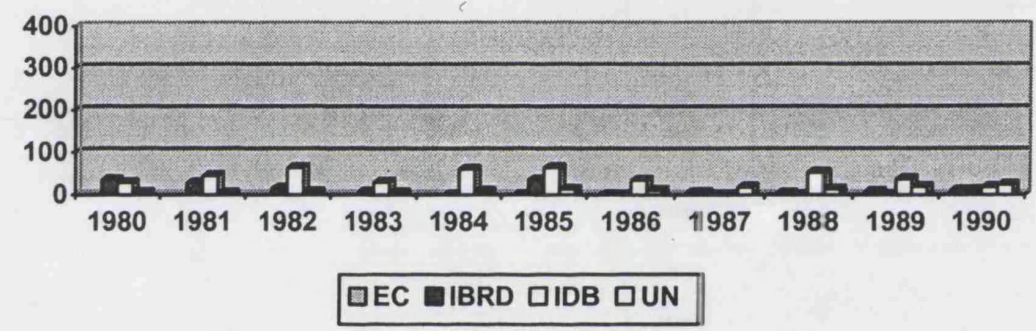

Multilateral Aid 1991-2000 in US\$ Millions

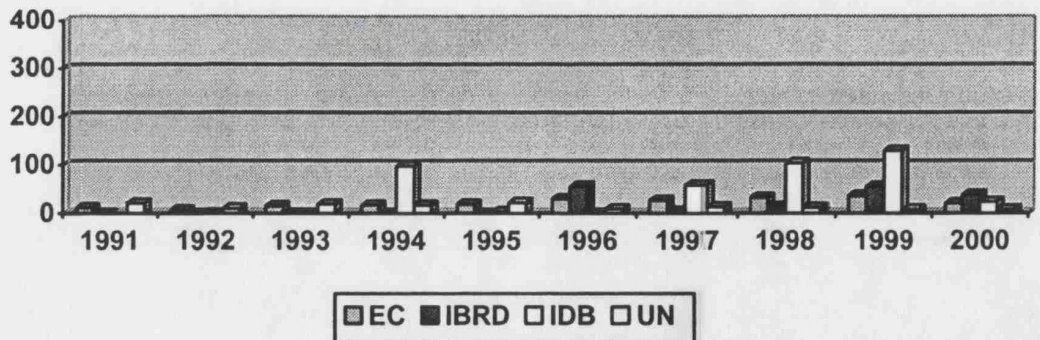

Source: (OECD)

Although it failed to produce a peace plan for the region, the Contadora process established important understandings that would inform the parameters of future discussions: the weight given to redefining the causes of conflict in 'local' terms; the involvement of Europe in the region, and a particular understanding of 
'democratisation'. The process also set the stage for the Esquípulas agreements, which would play a more direct role in shaping the Guatemalan peace process.

\section{Esquípulas}

The Esquípulas meetings, initiated in 1986, are associated with the elections of Vinicio Cerezo in Guatemala and of Oscar Arias in Costa Rica. Cerezo called the first meeting, Esquípulas I, in late May 1986 to continue Guatemala's policy of 'active neutrality' in the regional peace efforts as a way to reduce Guatemala's international isolation (Godoy, 1987). ${ }^{122}$ (Indeed, at his inauguration in January 1986, Cerezo had the Central American heads of state in attendance endorse the Caraballeda declaration, essentially a reiteration of the Contadora process' 1984 Revised Draft treaty (Bagley, 1986: 15); (Moreno, 1994: 69).) Esquípulas I did not create a clear plan for the end of conflict, but it did reiterate the principle of regional democracy - understood as Western-style liberal d emocracy - as a s olution to conflict, and p ressured $\mathrm{N}$ icaragua to transform itself towards that ideal (Moreno, 1994: 75).

Oscar Arias took up the regional peace process and invested it with active leadership and personal diplomacy, particularly vis-à-vis Western Europe and the (then) European Community (EC; (Andersen, 1992: 444). ${ }^{123}$ Indeed, the Arias effort understood that European support for the Sandinistas was waning and 'capitalized on these attitudinal shifts, securing official support from both individual governments and

\footnotetext{
122 'Active neutrality' was begun under Mejía Víctores. In Cerezo's efforts to consolidate the policy ('Active neutrality means not only that we are neutral, but also that we seek and propose formulas for negotiated settlements to conflicts') he declared: 'Guatemala's international isolation is a thing of the past'. Julio Godoy, 'Duarte, Arias Visits End Year of Diplomatic Successes', Inter Press Service, 4 December 1987.

${ }^{123}$ For an explanation of the domestic factors behind Arias's election and regional peace initiative, see: Moreno, The Struggle for Peace in Central America, chapter 4.
} 
the European Community prior to the 1987 Esquipulas meeting' (Andersen, 1992: 451-2). Widespread support for the initiative divided both the Reagan and Thatcher governments between conservative hardliners and more centrist Arias supporters ('Arias's Central American peace plan gains European support,' 1987) (Steele, 1987).

Esquípulas II, the Arias peace plan, was signed 7 August 1987. It called for the end of outside s upport to insurgencies, internal d emocratisation and elections, and $\mathrm{n}$ ational reconciliation (Moreno, 1994: 191). ${ }^{124}$ In its emphasis on controlling insurgencies, the plan privileged the governments in office (requesting that 'the irregular forces and insurgent groups operating in Central America ... refrain from receiving such aid in order to demonstrate a genuine spirit of Latin Americanism' (Moreno, 1994: 195)). It also specifically thanked the European Community and asked 'the international community to respect and assist our efforts. We have our own approaches to peace and development but we need help in making them a reality. We ask for an international response which will guarantee development so that peace we are seeking can be a lasting one' (Moreno, 1994: 191-2). The construction of a regional peace process around the legality of the elected governments of the region, which was largely supported by European governments, also meant an end to private 'solidarity' assistance: Esquípulas was perceived as the 'end to the revolutionary option' by private European aid agencies (Biekart, 1999: 209).

Laurence Whitehead argues that the primary difference between Contadora and Esquípulas involved the latter's stress on the 'necessity for internally democratic

124 This and the next two citations in this paragraph refer to the text of the agreement, which can be found in: Moreno, The Struggle for Peace in Central America, appendix 5. 
processes' (Whitehead, 1996: 245). According to interviews with the Costa Rican Foreign Minister, Arias 'assured the Reagan administration that, unlike Contadora, his peace plan would result in the restructuring of the Nicaraguan policy' (Moreno, 1994: 86-87). Such 'democratisation' was code for ensuring the peace process would not legitimise the Nicaraguan regime (Moreno, 1994: 87). Thus the Arias peace process, 'brought an imposing array of international pressures to bear on the Sandinistas, forcing them to democratize [sic.]. The Sandinistas were confronted not only with the contras and the United States' economic embargo, but also with a more sceptical Western Europe and an increasingly reluctant Soviet Union' (Moreno, 1994: 134).

The Esquípulas programme also amplified Contadora in its involvement of multilateral agencies in the region. As Robert Andersen observes, 'The Arias Peace Plan developed outside of the context of either the United Nations or the Organization of American States but, in contrast to Contadora, incorporated and heightened the profile of both organizations (particularly the United Nations) in the implementation of the accords' (Andersen, 1992: 444). The Esquípulas II agreement created a role for the UN as a monitoring force, the UN Observer Group in Central America (ONUCA). In principle, peace processes would occur simultaneously within the five countries of the Isthmus, however, the UN's 'management of the armed conflicts', as Stephen Baranyi puts it, occurred sequentially: Nicaragua (1989-90), El Salvador (1990-94) and Guatemala (1994-96 for the peace process itself, with an ongoing presence for the implementation of the agreements, (Baranyi, 1996: 248). (The Salvadoran case particularly would serve as an example for the negotiators of the Guatemalan agreement, especially regarding the necessity of coordination between the UN and the IFIs (the IMF and the World Bank; (Burgerman, 2000: , Whitfield, 1999).) 
European and US involvement in Central America converges through the regional peace processes. Kees Biekart suggests the mutual terrain of what were commonly understood to be divergent perspectives when he observes 'The United States and the majority of European governments had different views about how to rebuild the "political centre" that was destroyed by authoritarian regimes in the late 1970s, and about how to strengthen civil society' (Biekart, 1999: 173, emphasis added). Though their analyses of the causes of the region's conflicts differed ('local' versus 'external'), Northern governments were unified in seeking to establish a political centre and rebuild civil society. The political divisions within the US on its policy in the region, furthermore, were significant. Laurence Whitehead captures the bounded nature of the US-EU differences in observing that not only was US opinion deeply divided ('with many Democrats closer to Brussels than to the White House in their definitions of the issues'), but that 'successful European policy could hardly be rated a moral affront to the United States' (Whitehead, 1996: 234). ${ }^{125}$ Whitehead emphasises the compatibility of Western interests, characterising the situation in terms of a 'carrot and stick' approach, where 'through a process of tacit co-operation the EC acquired the function of offering the carrots leaving the USA free to concentrate on administering the sticks' (Whitehead, 1996: 235).

The regional peace processes, in a reflexive dynamic with the process of 'democratisation', created a particular landscape for international involvement in the region based on particular norms. Democratisation is understood as narrow electoral, democracy and in terms that allow for the 'legitimate' reconstruction of the

${ }^{125}$ Indeed, Adolofo Aguilar Zinser argues that the Contadora process failed in part from its lack of initiative in lobbying the US Congress against the Reagan administration's policies. Aguilar Zinser, Negotiation in Conflict: Central America and Contadora', 109-10. 
Nicaraguan polity. The simultaneous delegitimisation of insurgency affected the possibilities for 'solidarity' assistance and the revolutionary option. Civil society becomes the site for reconstructing the 'political centre', and as the conflicts are increasingly secured, this assistance becomes increasingly technical in nature. The relative success of the Arias peace plan in consolidating international support for a 'local' reading of regional conflicts - the 'social bases of conflict' - in the face of the Reagan administration's policies nonetheless establishes quite narrow parameters for such issues. The norms that emerge out of the regional peace processes are constructed so as to allow for the continuation of elite rule, under the rubric of negotiated peace.

\section{The Guatemalan peace process}

The move to civilian rule in Guatemala constructed a constitution that provided a slight political opening but also legitimised the coercion of counterinsurgency. The regional peace processes served as a form of intellectual and moral leadership that constructed the parameters of the Guatemalan peace process, particularly in terms of the dominant definition of democracy as the end of the revolutionary option. It also established the use of electoral democracy and civil society as means of illustrating consent, both elements that would be reiterated in the Guatemalan peace process. Yet the national peace process also provided a second moment of social transformation, largely designed to resolve the ongoing insurgency that could now no longer be eliminated militarily - regardless of the military's ability to do so - due to the logic of the regional processes in which Guatemala had become involved. It therefore raises new questions of the possibilities for social change. 
The scale of the peace process in Guatemala is significant, involving on the order of 17 agreements over eight years. ${ }^{126}$ In this section, the negotiations prior to the 1995 elections are examined. In the agenda setting phase of the negotiations, the problematic of establishing a common terrain for negotiations involved the international sponsorship of discussions between the URNG and various social sectors that established the electoral system as a central legitimating feature of the process. When negotiations stalled, a governmental crisis allowed private sector elites to lead a 'consensus-building' process that would underscore its dominant position in 'civil society'. UN conciliation in the peace process would further construct a legitimating role for civil society within significant limitations; in this process rights become understood as exclusively political and the 'essential' is deferred until after the 1995 elections, a moment of 'democratic' participation that would in fact destabilise the peace process.

\footnotetext{
${ }^{126}$ As discussed below, the process included agreements between various parties, not necessarily exclusively the government and the guerrilla (URNG), thus the number varies according to what criteria are used. Further, not all of the agreements between the government and the URNG are substantive agreements, several are procedural. The substantive agreements between the URNG and the government are commonly understood as: Framework Agreement for the Resumption of the Negotiating Process (Mexico, 10 Ja nuary 1994), Comprehensive Agreement Human Rights (Mexico, 29 March 1994), Agreement on Resettlement of the Population Groups Uprooted by the Armed Conflict (Oslo, 17 June 1994), Agreement on the Historical Clarification (Oslo, 23 June 1994), Agreement on Identity and Rights of Indigenous Peoples (Mexico, 31 March 1995), Agreement on Social and Economic Aspects and Agrarian Situation (Mexico, 6 May 1996), Agreement on the Strengthening of Civilian Power and on the Role of the Armed Forces in a Democratic Society (Mexico, 19 September 1996), Agreement on the Basis for the Legal Integration of the Unidad Revolucionaria Nacional Guatemalteca (Madrid, 12 December 1996), Agreement on a Firm and Lasting Peace (Guatemala, 29 December 1996). The Agreement on Constitutional Reforms and the Electoral Regime (Estocolmo (Sweden), 7 December 1996) was considered procedural, although it has significant implications for the fate of several substantive accords, as discussed below.
} 


\section{Agenda setting}

When speaking about the motivations to participate in the peace process, 'pro'-peace members of CACIF cite issues such as the need for security for tourism, capital (financial regulations and the rule of law), and sufficient stability for long term economic planning (Briz, 2001); (Pivaral, 2001); (Gonzalez, 2001). The 'anti'-peace process $p$ erspective, by contrast, expressed $\mathrm{i}$ tself through the s ense that the military option of defeating the 'illegal/lawless' insurgency still existed or that congress - not the 'narrow, elitist' peace negotiations - was the appropriate venue for discussing political change (Gonzalez, 2001); (Briz, 2001). The URNG describes its involvement in the peace process in terms of a gradual process of beginning to explore the possibility of a political solution, understood as the ability to establish the social bases of war as the foundation for negotiations (Noriega, 2001); (Asturias, 2001).

The first phase of the peace process involved an agenda setting process. Esquípulas II called for the formation of a Comisión Nacional de Reconciliación (National Reconciliation Commission, CNR), which sponsored a national dialogue that brought peace explicitly onto the national agenda. The URNG and the CNR signed the Oslo Accord, subtitled the 'Basic Accord for the Search for Peace through Political Means', (30 March 1990) which promoted the idea of discussions between the URNG and various sectors of society. The URNG subsequently (June-October 1990) held meetings with political parties, CACIF, religious representatives, labour and popular organisations, and representatives of small business, cooperatives, and academe. These internationally-hosted meetings resulted in a number of texts regarding goals for the process. 
The meeting with the political parties resulted in the 'Acuerdo de El Escorial', signed by many political parties, the URNG, and the CNR. It contained five points promoting the Oslo Accord and institutional reform to advance democracy in Guatemala, including reform of the judicial system, respect for the rule of law and a ceasefire during the electoral process (Acuerdo de El Escorial). Thus the agenda of privileging electoral politics was established with the commitment of a ceasefire, but with no specifics on the reform of the electoral system to ensure participation. Indeed, electoral reform would only be discussed at the end of the peace process, after the 1995 presidential elections. The meeting between CACIF and the URNG failed to produce a joint document, although both sides did nonetheless issue declarations to express their good will towards the process. ${ }^{127}$ CACIF noted in the first point of its declaration the importance of 'the eradication of violence, as [the] necessary element for Guatemala to achieve sustainable and stable economic and social development' underscoring the economic purpose of the peace process (Comunicado del CACIF en Ottawa).

Jorge Serrano Elías was elected in 1991, and continued the peace process, albeit initially o nly reiterating the O slo A ccord through a r enegotiated 'Agreement on the Procedure for the Search for Peace by Political Means' (Mexico, 26 April 1991). In the peace platform put forward by the URNG in May 1992, a particular understanding of development emerges: one of national development based upon education, health, nutrition, housing, support for small and medium producers and businesses, and the reform of land tenure, foreign trade, foreign investments, and taxation (URNG, 1992).

127 The URNG and CACIF accounts of this meeting differ significantly: the URNG describes it as very combative, tense, and aggressive, while the private sector described it as the occasion where the private sector communicated its good will towards open communication. Arnoldo Noriega, interview, 25 April 2001; Eduardo Gonzalez, interview, 24 April 2001. 
(The negotiations would privilege and reconstruct the URNG's social development agenda in a particular way, while marginalising its economic and fiscal agenda, as discussed below.) As the negotiations progressed, the URNG would become increasingly convinced that rural development rather than land reform was necessary to solve the problems in the countryside (Noriega, 2001). Significantly, the URNG called for civil society representation with observer status in the negotiations (URNG, 1992).

The first phase of the peace process provided intellectual and moral leadership establishing certain elements of the peace process, particularly the question of the use of the electoral system to promote democracy and the need for economic development as part of the peace accords. It also established the URNG's support for the involvement of civil society, albeit a role limited and defined by the negotiating parties.

\section{Crisis and 'Consensus Inc.'}

The second phase of the peace process involves the crisis of the Serrano government that ended in an unsuccessful attempt to recover power through a self-coup (autogolpe or Serranazo). Negotiations had stalled; the period leading to the Serranazo was marked by a period of social unrest and military exchanges. The government's coalition began to break down in early 1993, which led to the auto-golpe in May 1993 (Palencia Prado, 1996). ${ }^{128}$ The auto-golpe failed and brought the Human Rights

128 Serrano's auto-golpe has been compared to that of Fujimori in Peru. See: McCleary, Dictating Democracy: Guatemala and the End of Violent Revolution, for how the similarity may have pressured international actors to respond. 
Ombudsman to the Presidency through a new mechanism, the Instancia Nacional de Consenso (National Consensus Body, INC).

The Instancia emerged from the 'Foro Multisectoral' - CACIF's renamed Strategic Committee - which then invited broader participation, from the alternative / popular 'Foro Multisectoral Social' (McCleary, 1999: 110, 27). The 'popular', 'democratic' response to the auto-golpe was in fact strongly dominated by CACIF (McCleary, 1999: 192). The discourse of elite-led theories regarding the Instancia is that it was characterised by 'compromise and negotiation' and that it 'represented the political will of Guatemalan society' (McCleary, 1999: 192). In fact, popular organisations felt they had little alternative but to follow the private sector's lead. One union leader noted that 'for the unions and popular movement there was no other choice but to participate in the [INC], despite the risk this represents. We had to take advantage of the spaces opening up ... because to the contrary, only political and business sectors would have resolved the problem' (Central America Report, 1993). This sense may have been exacerbated by the failure of the URNG to take a stand on the crisis, due in part to its still tentative participation in the peace process at this stage (Noriega, 2001); (Azpuru, 1999).

The international community strongly condemned the Serranazo, which assisted domestic actors in coalescing around a rejection of such auto-golpe tactics, yet also thus implicitly endorsed the resolution of the crisis in terms of the organisation of 'civil society' by economic elites (Jonas, 2001); (Central America Report, 1993). 


\section{UN conciliation and the Civil Society Assembly}

The bulk of the agreements were signed 1994-1996 under UN conciliation. The resolution of the Serranazo led to the Ramiro de Leon Carpio assuming the Presidency in June 1993. Despite having been Human Rights Ombudsman, de Leon Carpio's initial treatment of the peace process had a destabilising effect in its introduction of a set of new rules for the negotiations. International pressure on the government led to the signing of a procedural accord bridging this impasse (Aguilera, et al., 1996).

The 1994 Framework Accord (Mexico, 10 January) did three noteworthy things. First, it institutionalised the role of the international community in the peace process: UN involvement was intensified from observer status to that of moderator, and the Groups of Friend states (involving the US, Spain, Mexico, Norway, Colombia, and Venezuela) was officially formed, tasked with providing 'security and firmness' to the commitments (Palencia Prado, 1996: 20). ${ }^{129}$ Second, the Framework Accord collapsed into one theme the 'socio-economic aspects' and 'agrarian situation' (Baranyi, 1995: 6). This is the first step in a narrow conceptualisation of the agrarian situation, which would be further reified in the Socio-Economic Accord. Finally, the Framework Accord established a formal role for the Asamblea de Sociedad Civil (Civil Society Assembly, ASC).

The ASC emerged from the National Reconciliation Commission of the first phase of the negotiations, and was headed by Msgr. Quezada Turuño, the former president of that Commission and ex-conciliator of the peace process. The Framework Accord gave

129 Rodrigo Asturias argues the URNG requested the US as a 'friend' government, given its sense that US foreign policy had changed and it would have the influence to ensure the Guatemalan government lived up to its commitments. Rodrigo Asturias, interview, 6 April 2001. 
the ASC the right to 'advise' (in a non-binding way) the formal negotiating process and the right to either accept or reject the accords; it became a parallel organisation to the formal peace process.

The role given to the ASC is significant in several respects. The ASC is put into the position of informing the national discussion from the margin: needing to create its own c onsensus first, and then $b$ ring $i$ ts positions to the $t$ able. In at $l$ east $t$ wo a reas, significant compromises took place in the ASC before reaching the formal negotiating table regarding indigenous autonomy and land (Sieder, 1997: 68); (Palma Murga, 1997). Furthermore, CACIF, with its independent resources, did not participate in the ASC. ${ }^{130}$ It had different access to the negotiations, lobbying the peace commission (COPAZ), the Group of Friends, the UN moderation and even the URNG directly, rather than presenting its proposals directly to the negotiations as the ASC did (Krznaric, 1999: 12). ${ }^{131}$ Nonetheless, several ASC proposed texts (e.g., regarding the Armed Forces Accord) were adopted by the URNG and became the basis for negotiations with this support. The URNG held the view that the ASC played a big role in the negotiations and had excellent results as a reference point for popular claims (Asturias, 2001).

${ }^{130}$ For a discussion of the resources CACIF was able to bring to the negotiations, see McCleary, Dictating Democracy: Guatemala and the End of Violent Revolution .

${ }^{131}$ As Roman Krznaric has pointed out, analyses that examine the empowerment of 'civil' groups 'informal' political processes should not neglect the power that 'uncivil' groups may wield in these processes as well. He considers CACIF an 'uncivil' group because of 'its historical propensity to support non-democratic politics and, more broadly, ... its attempts to limit citizenship rights in order to preserve economic privileges'. Roman Krznaric, 'Civil and Uncivil Actors in the Guatemalan Peace Process', Bulletin of Latin American Studies Research 18, no. 1 (1999): 15. 
The status of the ASC as a more publicly accountable body made it more vulnerable to pressure from international organisations. Roman Krznaric notes:

After the withdrawal of Quezada Toruño from the presidency of the ASC and during much of the rest of 1995, the information flow from the [UN] moderation to ASC was limited, which undermined the Asamblea's lobbying efforts. At other times the UN moderation attempted to limit ASC lobbying efforts more directly. After the Xamán massacre of returned refugees on 5 October 1995, for example, the UN asked the Asamblea to "not make too much noise" about the massacre as this would damage the peace process (Krznaric, 1999: 12).

Thus, the ASC not only provided a forum for expressing opinions but also for containing that participation. Krznaric remarks that, 'Actors within the Asamblea and outside observers agree that it would have been possible to have had a greater impact on the negotiations. More of its proposals could have been accepted in the accords, particularly on the Socioeconomic theme. Efforts to make the negotiations more transparent also largely failed' (Krznaric, 1999: 10).

The ASC is often described as an arena that built the political capacity of popular organisations. Susanne Jonas, for example, argues that the ASC gave groups that rejected electoral politics new political experiences that provided a basis for their participation in the 1995 elections (Jonas, 2000: 13). But the disciplining function of this new expertise is also clear: as Gabriel Aguilera suggests (unselfconsciously), 'the ASC became another arena of permanent negotiation in which participants perfected their understanding of tolerance and mutual concessions, taking into account that they reflected heterogeneity in their political criteria and in the social interests that they reflected' (Aguilera, et al., 1996: 23-23). The expectation is that organisations will converge into the 'apolitical centre', an area defined by powerful actors' sense of what is realistic and maintains stability. Thus the very claims of the ASC providing 
experience to popular organisations so that they might reincorporate into electoral politics expresses the logic of trasformismo.

The ASC was ultimately unsustainable. Three themes affected its longevity: the leadership vacuum left by the resignation of Mnsr. Quezada Turuño, the relatively specific mandate accorded to it by the Framework Accord, and the participation of some of the ASC in the 1995 elections as candidates for the Frente Democratico de Nueva Guatemala (FDNG; (Palencia Prado, 1996); (Krznaric, 1999: 9-12). The ASC was not an 'organic' political body, not because there was no pressure for social participation, but because it artificially aggregated too many positions. ${ }^{132}$ The departure of FDNG candidates and the failure to replace them exacerbated tensions between 'radical' and 'centrist' positions, provoking the departure of the Atlixco (academic/small business) sector and ultimately the creation of another body (the Democratic Civic Forum for Peace (FOCIDEP); (Krznaric, 1999: 10). The difficulty that the Atlixco sector perceived in relating to the popular movement illuminates the role this sector played as 'organic intellectuals', supporting the status quo. ${ }^{133}$

Four agreements were signed before the 1995 elections: accords on human rights, resettlement of refugees, 'historical clarification' (i.e., the principle of establishing a truth commission), and indigenous rights. All four of these accords exclude or defer

132 It should be noted that the ASC did successfully keep out 'army frontorganisations'. Krznaric, 'Civil and Uncivil Actors in the Guatemalan Peace Process': 9.

${ }^{133}$ 'Many sectors consider that Atlixco has tried to monopolise the Asamblea. The Atlixco group take the position that is was an 'open minority' in ASC and that the Asamblea is plagued by 'sectarianism, hegemony and dirigismo', with some individuals and groups having disproportionate influence in ASC and its various committees, such as the organising committee'. Krznaric, 'Civil and Uncivil Actors in the Guatemalan Peace Process': 10. 
land and economic issues until the negotiations for the Socio-Economic Accord. The two accords on rights, which are considered quite successful, thus construct a mutually reinforcing understanding of rights as devoid of a socio-economic dimension. Generally the guerrilla supported the order in which the issues were to be negotiated, based on the URNG's l ongstanding p rinciple that s ubstantive i ssues should p recede operational issues (Noriega, 2001). Yet this deferral of key issues around the elections had the effect of removing them from more popular pressures due to the tenuous outcome of the poll (discussed further below). The appeal to elections as part of the peace process in itself must be problematised: although little appears in the literature about objections to the elections - suggesting they were widely understood to be part of the 'democratic' process - when asked whether electoral politics work for the left, the guerrilla and popular / Maya organisations suggest that they do not: either due to lack of resources and experience (Asturias, 2001); (Macahio, 2001), or due to structural racism and exclusion (Raymundo, 2001) (Tiney, 2001). ${ }^{134}$

'The Comprehensive Agreement on Human Rights' was agreed in March 1994. This accord's scope only applied to the immediate situation and established the UN verification mission (MINUGUA). Violations worsened in the period between the accord's signature and MINUGUA's arrival in November (Jonas, 2000: 45). Nonetheless, MINUGUA itself has been considered a great success in lifting the pronounced ambience of fear that existed before its arrival (Palencia Prado, 1996: 34); (Louise, 1997: 57). It has particularly functioned as a dissuasive presence against

\footnotetext{
${ }^{134}$ In fact, participation reached its lowest point of the period 1950-1999 in 1990, with only 14.1 percent of those eligible voting. The figure was 14.5 percent in 1994 and 33.3 percent in 1995. Horacio Boneo and Edelberto Torres Rivas, '¿Por Qué no Votan los Guatemaltecos? Estudio de Participación y Abstención Electoral', (Guatemala: Tribunal Supremo Electoral, 2001).
} 
further human rights abuses (Louise, 1997: 61). MINUGUA has undoubtedly played an important role in opening political spaces and reducing fear in Guatemala. However, the boundaries of its presence must also be considered. MINUGUA has an explicit institution-building mandate, which reflects the evolving notion of UN peacekeeping that emerged from B outros B outros-Ghali's A genda for Development, with two main components: capacity building in juridical institutions and educational dissemination of human rights information (raising awareness of human rights). MINUGUA explicitly focused on civil and political rights as 'priority rights' for verification, to the exclusion of economic and social rights (Baranyi, 1995: 6). In 1995, Stephen Baranyi argued that this distinction 'could undermine future demands for the respect of e conomic and social rights', which did indeed come to pass by the 1996 Socio-Economic Accord (Baranyi, 1995: 6). ${ }^{135}$

In June 1994 the 'Agreement on the Resettlement of Population Groups Uprooted by Armed Conflict' (Oslo, 17 June) and the 'Agreement for the Establishment of the Commission to Clarify Past Human Rights Violations and Acts of Violence that have Caused the Guatemalan Population to Suffer' (Oslo, 23 June) were signed. The former involves the creation of a 'comprehensive reintegration plan' to promote the safe return or resettlement of displaced people and refugees. ${ }^{136}$ Though it recognised land

${ }^{135}$ Another concern is that 'institutional strengthening could modernise and legitimise institutions which are inherently unwilling to protect human rights by enforcing the law'. Stephen Baranyi, 'The Challenge in Guatemala: Verifying Human Rights, Strengthening National Institutions and Enhancing an Integrated UN Approach to Peace', (London: The Centre for the Study of Global Governance (London School of Economics), 1995), 19.

${ }^{136}$ Although by any measure an enormous problem in humanitarian terms and by proportion of the population, estimates regarding the magnitude of the displaced population vary significantly. According to Diana Pritchard, the counterinsurgency resulted in 500,000 internally displaced people, 44,000 recognised and an estimated 110,000 undocumented Guatemalan refugees throughout Mexico. Diana Pritchard, 
and land tenure as elements of this process, it deferred the substantive discussion of them until the Socio-Economic Accord. ${ }^{137}$ Because the accord would not go into immediate effect, it was subject to criticism by representatives of refugee committees (Jonas, 2000: 74).

The accord on Historical Clarification is considered the weakest of Guatemalan peace accords (Wilson, 1997: 19). It created a commission for Historical Clarification limited in scope (only abuses 'linked to the armed conflict'), time (six months, extendable to one year), legal prowess (no powers of search, seizure, nor subpoena) and that could not identify individual perpetrators (Wilson, 1997: 20). Gabriel Aguilera argues that, given serious disagreements, this accord was signed 'only thanks to a particularly intense intervention of international actors, especially one of the friend countries, that principally pressured the insurgents' (Aguilera, et al., 1996: 18). The accord provoked public outrage and represented a loss of credibility for the URNG, which affected its ability to negotiate subsequent issues (Wilson, 1997: 24); (Aguilera, et al., 1996: 18). This document was considered weak not only vis-à-vis the initial text proposed by the $\mathrm{ASC}, \mathrm{b}$ ut a lso v is-à-vis the S alvadoran agreement for a truth commission (Baranyi, 1995: 9).

'Refugee Repatriation and Reintegration', in Central America: Fragile Transition, ed. Rachel Sieder (London: Macmillan, 1996), 122. Finn Stepputat provides higher figures: one million internally displaced people and on the order of 350,000-400,000 refugees abroad, primarily in Mexico and the US. Finn Stepputat, 'Politics of Displacement in Guatemala', Journal of Historical Sociology 12, no. 1 (1999): 55.

${ }^{137}$ The language of the Resettlement Accord understands land as a question of title, underscoring property rights, and reiterates the constitution as the basis for participation in agrarian development; see the discussion of the texts of the SocioEconomic Accord below as well. 
With the November 1995 election in mind, the UN pressured the parties to conclude negotiations of substantive themes by August 1995 (Aguilera, et al., 1996: 246). The Indigenous Rights Accord was signed in late March 1995. In many respects a far reaching accord, it recognises the Guatemalan nation as 'multi-ethnic, multicultural and multilingual', and 'respect the identity and political, economic, social, and cultural rights of the Maya, Garifuna and Xinca peoples' (Agreement on the Identity and Rights of Indigenous Peoples, 1995: para. 3-4). As noted in the Introduction, Christopher Chase-Dunn calls the accord 'a conceptual breakthrough that many other countries should emulate' (Chase-Dunn, 2000: 109). This achievement of the acknowledgement of indigenous rights - e.g., to bilingual education, freedom from discrimination, the protection of indigenous names and sacred sites, etc. - in a structurally racist society is very significant. ${ }^{138}$

In fact, it has been argued that the strength of the text of the Indigenous Rights Accord and the political mobilisation of the indigenous community around the accords are two primary foundations for claims of 'empowerment' during the peace process. Rachel Sieder argues that:

more than any other factor...it was probably the independence and self confidence of Mayan actors in the peace process which confirmed the transformation in indigenous identity politics. During discussions of the [indigenous accord], it became evident that non-indigenous intermediaries were no longer necessary... (Sieder, 1997)

Nonetheless, there are several drawbacks to how the accord was agreed. Notably, as per the structure of the negotiations generally, indigenous representatives were not able to sit at the negotiating table (Sieder, 1997: 68). Furthermore, there was

${ }^{138}$ Many indigenous groups are satisfied with the accord, but not that it relied upon a package of constitutional reforms that failed, as discussed further below. Francisco Raymundo, interview, 2 April 2001. 
significant compromise on the issue of Mayan autonomy within the ASC - i.e. between Maya and non-Maya groups - before proposals reached the actual negotiation table (Sieder, 1997: 68). Kay Warren reports, 'Mayanists hold that the accord process was seriously compromised by secrecy, limited Maya input, and disregard of indigenous norms of consultation with communities and elders. Of great concern is the fact that the final document dealt only obliquely with collective rights' (Warren, 1998: 56). ${ }^{139}$ Finally, two key issues were deferred to subsequent accords: the issue of Mayan lands and demilitarisation in Mayan communities (Sieder, 1997: 69-70); (Aguilera, et al., 1996: 247).

The text of the Indigenous Rights accord engaged in two further 'deferral' tactics. Key elements - c entrally the redefinition of Guatemala as a 'national u nity, multiethnic, multicultural, and multilingual', the recognition of all existing languages, and the protection of spiritual practices (Agreement on the Identity and Rights of Indigenous Peoples, 1995: IIV A, IIIA2a, IIIC3) - would also be contingent on constitutional reform (dealt with in one of the final operational accords, as below). The agreement also relies on the establishment of joint commissions to explore education reform, 'reform and participation' in national life and land rights. These commissions would be composed of equal numbers of government representatives and representatives of indigenous organisation. Crucially, they are established to operate by consensus. In fact, the consensus requirement led to long delays in the resolution of the themes that the joint commissions were established to deal with and the indigenous organisations

${ }^{139}$ Even representatives of such prominent organisations as the widow's association CONAVIGUA express the sentiment that the negotiations took place in a context 'very isolated form the population'. T. Macahio, interview, 23 April 2001. 
that participated in the commissions lost credibility among the popular sectors (Raymundo, 2001); (Tiney, 2001); (Macahio, 2001).

The Guatemalan peace process before the 1995 elections is marked by the cultivation of consent through international support in agenda setting, through the resolution of the auto-golpe, and with mechanisms such as the ASC under UN mediation. UN conciliation is marked by an elaborate effort to involve civil society in the negotiations, however, one that does not overcome the pre-existing social power inequities in Guatemala; it functions precisely to preserve elite power and to cultivate the appearance of broad popular consent through 'participation' in 'openly contested' negotiations. While the UN's presence via MINUGUA clearly improved the conditions for popular organising, which contributed to participation in formulating the Indigenous Rights Accord, the UN also undermined the URNG's position in the negotiations in its pressure for limited historical clarification. The categorical deferral of socio-economic issues constructs a narrow understanding of rights as purely 'political', devoid of socio-economic content, while other deferral strategies - the electoral dimension of constitutional reform, consensus-driven joint commissions would later compromise the implementation of the agreements.

\section{Negotiating the 'essential'}

The November 1995 elections would open up questions of intra-elite differences regarding the solution of the contradictions of counterinsurgency. They resulted in a run-off between the CACIF-oriented the Partido de Anvanzada Nacional (National Advancement Party, PAN) and the Frente Republicano Guatemalteco (Guatemalan Republican Front, FRG), which the PAN's Alvaro Arzú won by two percent. The FRG 
is the party of Efraín Ríos Montt; constitutionally barred from holding presidential office again, Montt was still seen to be the behind-the-scenes leader of the party. ${ }^{140}$ The PAN has a strong relationship with CACIF and fewer ties to the military; indeed Arzú, specifically sought independence from the military in the negotiations (Arnault, 2001).

The election can be read as a contest over the resolution of counterinsurgency. The FRG represented one solution: a right-wing, populist-military solution that would marginalise the 'establishment' private sector while promising evangelical renewal. Ríos Montt was associated with a counterinsurgency 'development' programme, 'fusiles $y$ frijoles' ('guns and beans'), that included the promotion of community-based nontraditional agrarian export-led growth. Before he lost CACIF's confidence, McCleary argues that 'economic elites welcomed opportunities for economic growth through state-led trade liberalization', 'as long as this export-led model focused on small producers and did not entail confiscation of assets by the state' (McCleary, 1999: 48-49). The FRG ran in the 1995 elections on a platform of economic liberalisation and privatisation as did the PAN, yet it sought to pursue a developmentalist project independent from CACIF (FRG, 2001). The PAN, on the other hand, in its 'pro-peace' platform, implied the resolution of counterinsurgency through the subordination of the military to civilian government with the support and 'modernising' economic agenda of CACIF, including sectors such as tourism, that required the end to military excess.

Neither of these positions entirely resolves both elements of disarticulated counterinsurgency: one maintains the counterinsurgent military while challenging the

${ }^{140}$ One of the great controversies since 2000 has been Ríos Montt's challenges to the constitutional limitations on his participation in politics, discussed further in the Conclusion. 
privilege of the dominant economic elite; the other maintains the economic privilege of a particular modernising agenda while subordinating the military. Yet both express a kind of caesarism in their two forms of novel 'revolution-restoration'. Each implies a different form of trasformismo, cooptation of the economic through a developmentalist project in the c ase of the FRG, and c ooptation of the threat to disarticulation - the guerrilla and the 'dangerous' elements of civil society -through the assimilation into electoral and consensual governance processes, in the case of the PAN. This debate represents the backdrop of the negotiations of the essential: it embodies enormous tensions precisely because of the divergent natures of the attempts to restore (certain elements of) the social order. Such tensions would be significant in the accords' implementation (discussed further below and in the conclusions).

Nonetheless, taken together the FRG-PAN showing illustrated above all an unreformed electoral system's preference for an elite-oriented solution to the contradiction of c ounterinsurgency. Whatever the r elative instability of the caesarist solutions represented by the FRG and the PAN, by this point popular forces had been 'secured' by the peace process to a significant extent, through their incorporation into electoral politics and the governance project implied by an organised civil society.

To leftist analysts such as Edelberto Torres-Rivas, the FRG/PAN contest reflected 'the "deideologification" of the e lectoral d ebate, the distaste for p olitics, that took p lace everywhere, which reduced itself to a poor [political] programme, to a basic package of small material offerings and a millionaire's game of telegenic images' (TorresRivas, 1997: 25). Yet, two features of the election promoted a sense of contestation. One was the unprecedented call by the URNG for public participation. The second was the unexpected showing of the leftist coalition party Frente Democrático Nueva 
Guatemala (FDNG), which won six (of 80) seats. Jonas, for example, concludes 'Until they actually occurred, such results had not been believed possible in Guatemala' (Jonas, 2000: 47). Clearly, however, the magnitude of this result was relatively insignificant $v$ is-à-vis d ominant interests. E lectoral $r$ eform would be o ne of the last issues dealt with in the accords, as discussed below.

The narrow electoral victory of 'pro-peace' forces would enhance the position of the PAN in the negotiations: 'Armed with this specter [of the FRG], the PAN government was consistently able to gain a reluctant nod from the international community, even in the face of progress backwards [sic.]' (Jonas, 2000: 176). It is in this context that the signing of the subsequent accords, dealing with socio-economic issues, military reform, the reintegration of the guerrilla and electoral reform, should be considered.

\section{Socio-Economic Accord}

The Socio-Economic Accord was signed in May 1996. As with previous accords, notably the Indigenous Rights agreement, the ASC played a moderating role in bringing the text of a potential accord closer to dominant interests, which was then further compromised in the negotiations proper. The URNG saw the agreement in terms of the exigencies of external realities and the historical moment, but sought to emphasise the opportunities for future improvements that the accords afforded. International actors considered the accord a success in its ability to appeal to international donors (World Bank, IMF) and to powerful local actors, especially CACIF, which declared the accord a great achievement.

The ASC functioned as a forum for mitigating popular demands for land reform in its discussions of a potential socio-economic accord, debating but ultimately not including 
in its proposals a redefinition of land ownership and use based on the 'social function' of property (Palma Murga, 1997: 76). Gustavo Palma Murga notes that:

The ASC proposals made tacit concessions to the neo-liberal preoccupations of the private sector. They recommended more 'rational and efficient use of the land' not only to increase production and meet historical grievances, but also to reflect the competitive 'comparative advantage' of Guatemala in the new global economy (Palma Murga, 1997: 76).

The negotiated texts of the accord received less enthusiastic reception from popular organisations, whose reactions varied from vocal opposition to resigned acceptance, concerned primarily with the possibilities for the accord to address land conflicts (Palma Murga, 1997: 78). Palma Murga argues that many popular organisations perceived that the guerrilla's concessions on land were related to concluding the negotiations quickly in order to further their own political ambitions in the postconflict state (Palma M urga, 1997: 78). Ultimately the A SC did endorse the SocioEconomic Accord - after a two month delay - in July 1996 (Jonas, 2000: 52).

The guerrilla had come to the conclusion that liberalism was an inevitable feature of the post-conflict state. Torres-Rivas notes that the URNG document, Guatemala: Full Democracy, Revolutionary Goal at the end of the Millennium, which articulates the position that the purpose of revolution can be democracy, also shows their decision to accept liberal democracy and self-regulating markets as the 'scenario that must be lived with at the end of this century' (Torres-Rivas, 1997: 41). ${ }^{141}$ A common response from guerrilleros regarding their compromises during the peace negotiations was that 'the correlation of forces was such that...' such compromises were necessary

${ }^{141}$ Unfortunately Torres-Rivas does not provide a citation and I have been unable to acquire a copy of this statement; the date of issue of which would of course be very interesting. It does not appear explicitly in the URNG's 1992 proposals to the government. URNG, 'Una Paz Justa y Democrática: Contenido de la Negociación', (Guatemala: 1992). 
(Noriega, 2001) (Asturias, 2001). The official response of the URNG involved a cautiously optimistic emphasis on the positive: that the accord represented the first engagement in land reform in years (Palma Murga, 1997: 78), and that the accord 'is not a complete solution to all problems, but it opens avenues and establishes commitments oriented towards resolving them' (Monsanto, 1996: 7). The URNG statement on the signing of the accord emphasised that the accord was not a blueprint for society, but a step towards peace and 'the participation of all in its construction' (Monsanto, 1996: 8).

The accord was widely understood, particularly in international organisations, to represent 'an alternative to neoliberalism' in its support for government involvement in the economy (Jonas, 2000: 80-81). Thus,

for those with a more positive interpretation, especially the UN and other international officials, the glass was more than half full. From their perspective, the accord embodied a comprehensive approach that everyone could live with; it was acceptable not only to CACIF but also to the international financial institutions (IFIs) in Washington (Jonas, 2000: 8081).

CACIF's reaction was one of 'enthusiasm', although it would resist elements of the accord in their implementation (Jonas, 2000: 80).

In sum, many popular and leftists thus resigned themselves to the necessity of such an accord, and ultimately accepted its logic as the viable compromise position: a process of trasformismo m ade legitimate b y the incorporation of the guerrilla into the postconflict political order and the endorsement of civil society through the ASC, reflecting a 'trade-off' logic of further participation. The agents of this process of trasformismo involved not just local modernising elites, but the international organisations that supported the implicit neoliberal economic logic of the accords, the 
IFIs, and that supported the parameters that this logic constructed for 'compromise', i.e., the UN. As will be discussed further b elow, this 'compromise' is in fact more 'neoliberal' than is commonly acknowledged, in that it relies on the construction of neoliberal subjectivity in the post-conflict state.

\section{Military reform and the reintegration of the URNG}

Robinson argues that in authoritarian-'democratic' transitions, controlled demilitarisation occurs because corrupt militaries obstruct capitalist modernisation through their pursuit of economic privilege; they are necessary only to the extent that social control requires coercion (Robinson, 1996: 66). 'Controlled' demilitarisation involves the subordination of military authority to civilian elites, but not the elimination of coercive military potential (Robinson, 1996: 66). As social control can be effectively devolved through the promotion of democracy-cum-polyarchy and the reconstruction of civil society in an analogous vein, such demilitarization can occur, and is indeed advantageous to elites (Robinson, 1996: 66-69).

Within the peace process of a civil war, the notion of demilitarisation involves more parties than just the state. Thus, in the Guatemalan peace process, there would be accords both on the Role of the Armed Forces in Society and on the demilitarisation of the guerrilla. The former to a large extent followed the logic of controlled demilitarisation that Robinson outlines, yet by the time the latter is discussed, events that discredited the guerrilla would have opened the door for another the devolution of social control to an even more decentralised level: that of individual political subjectivity through impunity. 
The controlled nature of demilitarisation was in the first instance conducted through 'self-purges' w ithin the military b efore the n egotiations p roper, a fter which o fficers were not affected by the reductions called for in the accords (Schirmer, 1998: 270-2); (Molina Mejía, 1999: 65). As a result of this preparation by the military, the ASC could construct a text that to a certain extent created the framework for the 'Agreement on the Strengthening of Civilian Power and the Role of the Armed Forces in a Democratic Society’.

The ASC, which had suffered significant organisational challenges by this point, put forward a rather reformist programme. ${ }^{142}$ As Torres-Rivas notes, the debate 'took place as always with references to the unconstitutionality of different points ... Nothing is said [in the accord] about substantive themes such as a new concept of national security, the significance of sovereignty in a global society, the utility of the military ...' (Torres-Rivas, 1997: 30, translation mine). He describes the negotiation as 'a battle of percentages' in its narrow discussions around the precise levels of military reduction (Torres-Rivas, 1997: 30).

The Armed Forces Accord would be limited vis-à-vis the ASC proposal in a few important ways: while it redefined the role of the military as relating only to the external security of the country (narrowing its previous remit of both internal and

142 The ASC called for: the reorientation of the military to external defence, its subordination to civil power, a 50 percent reduction in military personnel, equipment and troops, constitutional changes including allowing the Minister of Defence to be a civilian, the security of citizens to be the function of civilian security forces divorced from the military, the dismantlement of all the counterinsurgency structure including military intelligence and the $d$ issolution of the PACs, and the definition of $m$ ilitary service as voluntary with the possibility of conscientious objection. Asemblea de la Sociedad Civil, Propuesta de la Asamblea de la Sociedad Civil - El Ejercito en Democracia ([cited 10 June 2002]); available from http://www.us.net/cip/dialogue/1203.htm. 
external defence), it did so with the caveat that the President can call on the military for internal security in cases of emergency. The Accord did not reduce the army to the degree sought by the ASC or achieved in El Salvador (it was reduced by 33 percent rather than 50 percent); ${ }^{143}$ it also had very weak language and no verification measures for the demobilisation of PACs. Certain counterinsurgency groups and their training facilities were not decommissioned, nor were some intelligence organs (Jonas, 2000: 85). Internal security would be handled by a new National Police force, which lacked details regarding membership criteria, another weakness vis-à-vis the Salvadoran example. Most of these elements of the Armed Forces accord would be contingent on constitutional reforms (as with the Indigenous Rights agreement). Although the reaction to the Armed Forces accord was muted, those organisations that did issue statements were cautiously optimistic (Torres-Rivas, 1997: 111).

The guerrilla made a significant tactical error during the 1996 negotiations: one faction of the URNG (ORPA) kidnapped an 86-year-old member of the oligarchy, Olga Novella, for ransom, and the government ultimately consented to exchange her for the perpetrator. ${ }^{144}$ Kidnappings for ransom are not uncommon in Guatemala, but the timing and nature of this - apparently a fundraising exercise for ORPA and the future presidential campaign of its head, Rodrigo Asturias - seriously compromised the URNG's negotiating position (Noriega, 2001). The head of the ORPA resigned from their negotiating team, and the international community stepped in to finalise the

143 The reduction in the budget involves a 33 percent reduction in spending as a proportion of GDP from 1995 to 1999. Thus the proposed reduction would be somewhat off-set by the then projected economic growth. Raúl Molina Mejía, 'The Struggle Against Impunity in Guatemala', Social Justice 26, no. 4 (1999): 65.

${ }^{144}$ For details, see: Central America Report, 'ORPA Kidnapping Revealed; Peace Talks on Hold', Central America Report, 31 October 1996; Central America Report, 'Peace Negotiations Still in Limbo', Central America Report, 7 November 1996. 
logistical accords that remained. (It is interesting but not surprising that this miscalculation by o ne sector of the guerrilla would (allegedly) involve the electoral process: it exposes the implications that increased material requirements for campaigning have for the left.)

A series of final agreements were signed in December 1996, culminating in the 'Accord for a Firm and Lasting Peace'. These agreements were facilitated by the Friend Governments, which hosted a series of meetings in Europe involving both negotiators a nd civil s ociety to sign the final o perational a ccords, a tour to a chieve closure in the face of the setback of the Novella affair. These operational accords treated establishing a cease-fire, constitutional reforms, and the demobilisation of the URNG.

The Agreement on Constitutional Reform and the Electoral Regime called on the government to draft amendments to the constitution, as per the Indigenous Rights and Armed Forces agreements, and forward them to congress within 60 days of its entry into force (Agreement on Constitutional Reforms and the Electoral Regime, 1996). Such amendments would require a two-thirds majority there and final approval in a national referendum. The accord also provided for the study of the reform of the electoral system, underscoring the authority of the Tribunal Supremo Electoral, established by the 1985 constitution.

The demobilisation accord was very contentious because it reopened the sticky issue of amnesty. The agreement called for the creation of a special commission to involve the government, URNG, and international donor representatives, as well as a national law - a national reconciliation act - to be passed by the Guatemalan congress (Jonas, 
2000: 89). The law that emerged was ultimately very weak: it naturally needed to provide amnesty for 'political crimes' to allow for the re-incorporation of the URNG, but it understood 'political crimes' to involve both directly taking up arms against the government as well as 'related common crimes', 'which cannot be shown to be motivated by personal goals' (text in (Jonas, 2000: 90). This provided wide scope to amnesty counterinsurgency forces. The FRG and CACIF supported the agreement, while human rights activists, religious authorities, members of the FDNG and a number of indigenous organisations objected to it (Torres-Rivas, 1997: 133).

The agreements on military force and guerrilla demobilisation reflect a controlled demilitarisation. Traditional military apparatuses were subject only to limited reductions in a context where prior purges 'counted' towards the peace process. In addition to these 'objective' elements of coercion, the subjective element persists through military amnesties. The significant use of the ASC text engendered cautious but genuine consent in the case of the Armed Forces accord, while the accord on the guerrilla's demobilisation could be used for less acceptable amnesties, justified under the exigencies of the crisis of Novella affair.

\section{Articulating the post-conflict state: the texts of the accords}

The negotiation of the essential reflects a particular caesarist solution to the crisis of counterinsurgent disarticulation, one that was highly contingent upon' international involvement. In what follows, the specific nature of that 'revolution-restoration' is considered. Two areas in particular are important vis-à-vis the crisis of counterinsurgent disarticulation: the socio-economic and the military, and how they resolve questions of coercion and consent. The accords evidence a general trend 
towards the devolution of social control to the level of individual subjectivity: through the internalisation of market rationality in the case of the Socio-Economic Accord, and through an explicit emphasis on the individual as agent of modernisation in the case of the Armed Forces Accord; where coercion is maintained subjectively through the persistence of impunity as an unresolved element of the demilitarisation project.

\section{The Socio-Economic Accord}

As noted earlier, modernising elites were motivated to participate in the peace process for the purposes of stabilising the country to be able to engage in longer-term economic planning and to assure security for tourism and for capital (financial regulation and the rule of law). The guerrilla sought to address the social bases of conflict. The 'success' reading of the peace process understands the socio-economic agreement as a significant compromise that accommodates both the neoliberal orientation of CACIF and the IFIs in its use of market mechanisms, e.g., vis-à-vis the question of land, while addressing the guerrilla agenda by strengthening the capacity for government in areas such as taxation and supporting social spending (Jonas, 2000: 27). A critical perspective, however, seeks to examine the terms on which such a compromise is reached, particularly given the operation of power during the negotiations. The argument below is that the 'compromise' perspective misses to a large extent how neoliberal considerations may be embedded in the elements of the accord that reflect the URNG's agenda. What the success story perspective obscures is the extent to which neoliberalism in the periphery, particularly in a postcounterinsurgent disarticulated state, requires a particular juridical and institutional environment to function and seeks 'human capital' as an economic resource for the private sector and the nation-as-the-firm. An examination of the texts of the accords shows a strong neoliberal emphasis, both vis-à-vis the question of land, where such an 
orientation is commonly recognised, but also vis-à-vis fiscal and budgetary policy and spending and investment, where it is less so.

\section{Land}

The question of land is primarily addressed in the third section of the accord, The Agrarian Situation and Rural Development (see 'Outline of the Socio-Economic Accord' below). ${ }^{145}$ The accord begins with the statement that:

The transformation of the structure of land use and ownership must have as its objective the incorporation of the rural population into economic, social and political development so that the land constitutes, for those who work it, the basis of their economic stability, the foundation of their progressive social well-being and the guarantee of their freedom and dignity (Agreement on the Social and Economic Aspects and Agrarian Situation, 1996: ๆ27).

Yet in the next paragraph this is collapsed into the commitment to 'promote more efficient and more equitable farming' (Agreement on the Social and Economic Aspects and Agrarian Situation, 1996: \28). By the fourth paragraph the logic has transformed into one of security property rights: 'Solving the agrarian problem is a complex process covering many aspects of rural life, from modernisation of production and cultivation methods to environmental protection, as well as security of property, adequate use of the land and of the labour force ...' (Agreement on the Social and Economic Aspects and Agrarian Situation, 1996: ๆ30).

The primary mechanism with which the accord promotes the expansion of land ownership is through a National Trust Fund for Land, whereby the government buys land to 'promote the establishment of a transparent land market' (Agreement on the

${ }^{145}$ The text of the Socio-Economic Accord is included in Appendix 3. 
Social and Economic Aspects and Agrarian Situation, 1996: ๆ34(a)). The government undertakes to:

Promote, through all means possible, the development of a dynamic land market that would enable tenant farmers who either do not have land or have insufficient land to acquire land through long-term transactions at commercial or favourable interest rates with little or no down payment. In particular, promote the issuance of mortgage-backed securities guaranteed by the State whose yield is attractive to private investors, especially financial institutions (Agreement on the Social and Economic Aspects and Agrarian Situation, 1996: ๆ34(e)).

Other measures to assist private land ownership include legal reforms to simplify awarding title and registering ownership and 'an efficient, multi-user land registry system that is financially sustainable' (Agreement on the Social and Economic Aspects and Agrarian Situation, 1996: $\{37(\mathrm{a})$, ๆ38). Land would be acquired through the consolidation of uncultivated state land, the reappropriation of illegally settled lands, government purchases, including those supported by grants from foreign governments, international NGOs, and loans from IFIs (Agreement on the Social and Economic Aspects and Agrarian Situation, 1996: $\{34(\mathrm{c}))$. There are also measures for the resolution of land disputes, a significant issue for areas where there have been displaced communities, and promises to promote legislation for a land tax from which small holdings would be exempt.

The accord functions to promote a national land market through the privatisation of state land and through international assistance rather than pursuing genuine land reform. As Palma Murga describes it, 'resolution of the agrarian problem is understood as a process of reallocating resources within a marginally reformed institutional context based on private ownership and the market' (Palma Murga, 1997: 78). Although the question of illegally occupied lands does reflect an issue of justice for many indigenous communities, it also reflects a way to discipline corrupt military 
officers who participated in such acquisitions, particularly in the 1970s: the areas noted in the accord - the Franja Transversal del Norte and the Petén - were those known as the 'Land of the Generals'.

\section{Outline of the Socio-Economic Accord}

I. Democratisation and participatory development
A. Participation and consensus-building
B. Participation of women in economic and social development

II. Social development
A. Education and training
B. Health
C. Social security
D. Housing
E. Work

III. Agrarian situation and rural development
A. Participation
B. Access to land and productive resources
C. Support structure
D. Organisation of the rural population for production
E. Legal framework and juridical security
F. Land register
G. Labour protection
H. Environmental protection
I. Resources

IV. Modernisation of government services and fiscal policy
A. Modernisation of government services
B. Fiscal policy

V. Final Provisions

\section{Fiscal and budgetary policy}

Fiscal and budgetary policy are designed to strengthen the competitiveness of the country, which requires greater labour productivity and infrastructure. The accords call for an improvement in tax collection, a long-standing issue in Guatemala which had the lowest level of taxation in the Western Hemisphere for 1963-1983 (Dunkerley, 1990: 231). In the accords, fiscal policy is defended in terms of a Porter-like argument that lack of government spending has led to low levels of education, health, and 
infrastructure, 'which militate against increasing the productivity of labour and the competitiveness of the Guatemalan economy' (Agreement on the Social and Economic Aspects and Agrarian Situation, 1996: \45). Taxation and spending are understood in terms of the 'competitiveness of nations'. The accords aim to increase the tax burden as a ratio of GDP by 50 percent from 1995 levels by $2000 .{ }^{146}$ Furthermore, the enforcement of more regressive taxation, i.e., value-added tax, comes before the enforcement of the obligations of large contributors (Agreement on the Social and Economic A spects and Agrarian Situation, 1996: \50(d, e, g)). Thus, the p ursuit of taxation is cautious, and does not emphasise its redistributive potential. Taxation remains one of the most contentious issues in post-peace agreement politics (discussed further in the Conclusion).

\section{Growth and the post-conflict state}

The Socio-Economic Accord fundamentally prioritises growth over everything else.

The discourse of growth prefaces nearly every section of the agreements and growth precedes any mention of social development or justice every time either term appears

in the Accord. For example, the section 'Social Development' argues that:

In the quest for g rowth, economic policy should be a imed at preventing processes of socio-economic exclusion, such as unemployment and impoverishment, and maximizing the benefits of economic growth for all Guatemalans. In seeking to ensure the well-being of all Guatemalans, social p olicy should foster e conomic d evelopment through i ts i mpact on production and efficiency (Agreement on the Social and Economic Aspects and Agrarian Situation, 1996: \14).

${ }^{146}$ This was not successfully implemented, and led to a cycle of negotiations with international lenders in the form of consultative group meetings and a 'Pacto Fiscal' (fiscal pact). The IMF and World Bank would ultimately champion any progress in taxation, even regressive increases in VAT rather than more democratic measures. The Pacto Fiscal will be discussed further in the conclusions. For an overview, see: Nuria Gamboa M. and Barbara Trentavizi, La Guatemala Posible: La Senda del Pacto Fiscal (Guatemala: Asociación Centroamericana Hombres de Maíz, 2001). 
In this paragraph, the bottom line (literally) is that social policy should be designed to improve production and efficiency.

Regardless of whether growth in fact leads to development axiomatically, it will in the new Guatemalan state, for in fact social programs are designed to be contingent on a certain level of economic growth. ${ }^{147}$

For its part, the Government undertakes to adopt economic policies designed to achieve steady growth in the gross domestic product of not less than 6 per cent per annum, which would enable it to implement a progressive social policy (Agreement on the Social and Economic Aspects and Agrarian Situation, 1996: \18).

Thus, the accords construct a situation where the country is invested in economic growth as a requirement for the social services promised in the agreements. A failure to produce the social services promised can thus be excused by pointing to slow growth. $^{148}$

In this agreement, citizenship itself is defined as an economic good. The section 'Democratisation and Participatory Development' argues that functional, participatory democracy requires consensus building among 'agents of socio-economic

147 There is much good evidence that growth does not lead automatically to development. For diverse but compelling arguments, see: Victor Bulmer-Thomas, The New Economic Model in Latin American and its Impact on Income Distribution and Poverty (London: Institute for Latin American Studies, 1996); Elmar Altvater, 'The Growth Obsession', in Socialist Register 2002: A World of Contradictions, ed. Leo Panitch and Colin Leys (Black Point, Nova Scotia: Fernwood, 2002); Sharachchandra Lélé, 'Sustainable Development: A Critical Review', World Development 19, no. 6 (1991). Furthermore, as de Janvry argues, growth does not automatically lead to articulation, de Janvry, The Agrarian Question and Reformism in Latin America, 49.

${ }^{148}$ In fact, the annual percent increase in real GDP in Guatemala from 1995-2000 was: 4.9 (1995) 3.0 (1996) 4.4 (1997) 5.0 (1998) 3.6 (1999) 3.3 (2000). Quest Economics Database: Americas Review World of Information, Guatemala: Key Inidcators (Janet Matthews Information Services, 2001 [cited 1 July 2002]); available from LexisNexis; Alex Tanzi, IMF's Annual GDP Percent Change Forcasts (2001 [cited 1 July 2002]); available from Lexis-Nexis. 
development' as well as citizen participation in 'identifying, prioritising and meeting their needs' (Agreement on the Social and Economic Aspects and Agrarian Situation, 1996: 11$)$. The assumption is that such participation is 'essential in order to promote productivity and economic growth' (Agreement on the Social and Economic Aspects and Agrarian Situation, 1996: $\{2-3)$.

The state must play the role of brokering this consensus - 'essential in order to stimulate and stabilise economic and social growth' - 'in order to be able to work effectively and efficiently to modernise the production sector, enhance competitiveness, promote economic growth and provide basic social services efficiently and universally' (Agreement on the Social and Economic Aspects and Agrarian Situation, 1996: $\llbracket 2-3)$. A clear question that emerges is who will participate in this consensus. Point 4 acknowledges the right of indigenous and resettled peoples to 'exercise their rights effectively and participate fully in decision-making on the various matters affecting or involving them, with full awareness of both their individual and collective obligations to society, which they will fulfil responsibly' (Agreement on the Social and Economic Aspects and Agrarian Situation, 1996: 14, emphasis added). The right to participate is limited to 'matters affecting or involving them', while society is implied to be an entity which they are located outside of, and to which the obligations have already been determined. Not to acknowledge the individual and collective obligations is irresponsible and suggests a breach of the citizenship contract, presumably permitting the state to treat these groups and individuals differently.

There is an explicit sub-section for the status of women. This, too, is an economic affair, as it begins by 'recognising women's undervalued contributions in all spheres of 
economic and social activity...the Parties agree that there is a need to strengthen women's participation in economic and social development on equal terms' (Agreement on the Social and Economic Aspects and Agrarian Situation, 1996: 『12). It is interesting to note where else women's rights are articulated: primarily in the Indigenous Rights Accord. Women are not mentioned in the Agreement on Constitutional Reforms and the Electoral Regime, nor in the Comprehensive Agreement on Human Rights, and only once in the Agreement on Resettlement of the Population Groups Uprooted by the Armed Conflict. Women's rights to protection are articulated in the indigenous agreement while their obligations as economic agents are articulated in the socio-economic agreements, yet they do not explicitly appear much elsewhere in the accords. This reflects the construction of neoliberalism's need to manage the indigenous identity and socio-economic subjectivity, more than a comprehensive 'gendering' of the process. ${ }^{149}$

\section{Social spending and investment}

The accords go further than 'merely' casting citizenship in terms of economic agency: they provide a blueprint for the construction of economic agents in their treatment of education and training, work, and the organisation of the rural population for production.

Education is a highly economic good, "vital for economic modernisation and international c ompetitiveness' (Agreement on the Social and Economic Aspects and Agrarian Situation, 1996: $\mid 21)$. Education and training should 'contribute to the application of technical and scientific progress and, consequently, to the achievement

\footnotetext{
${ }^{149}$ For a discussion of women's rights as the 'missing accord', see Susanne Jonas, Of Centaurs and Doves: Guatemala's Peace Process (Oxford: Westview Press, 2000), 86.
} 
of higher productivity, the creation of more jobs and increased income for the population and beneficial integration into the world economy' (Agreement on the Social and Economic Aspects and Agrarian Situation, 1996: q21). The goal of education is thus to further the national economy and its globalised possibilities.

Work is defined in terms of the individual's development: it is 'essential for the integral development of the individual, the well-being of the family and the social and economic development of Guatemala' (Agreement on the Social and Economic Aspects and Agrarian Situation, 1996: 126). The role of labour is as 'an essential element of social participation in socio-economic development and of economic efficiency. In this respect, the state's policy with regard to work is critical for a strategy of growth with social justice' (Agreement on the Social and Economic Aspects and Agrarian Situation, 1996: ๆ26, emphasis added). The state is cast unambiguously as the guarantor of economic growth, and represents the manager who will mediate between growth and s ocial j ustice. Organised labour's role is likewise expressed in terms of promoting economic efficiency. The Accord's discourse on work involves the commodification of labour celebrated as beneficial for both the individual and the state, the latter of which controls the social dimensions of labour for the market.

The labourer in the neoliberal economy must possess a particular economic rationality. There is no mistaking that the accords aim to construct this rationality, as the subsection 'organisation of the rural population for production' evidences:

Organising the rural population is a decisive factor in transforming the inhabitants of the countryside into genuine protagonists of their own development...there is a need to promote a more efficient form of organisation of small producers so that they can, in particular, take advantage of the support structure described in paragraph 35 (Agreement on the Social and Economic Aspects and Agrarian Situation, 1996: \36). 
As with the discourse on work, participating in the reorganised, productive rural economy is good for the individual, indeed liberating (one becomes a 'genuine protagonist'). However, such participation requires becoming a micro-entrepreneur. The support structures in paragraph 35 involve the provision of infrastructure for the marketing of agricultural produce. The paragraph continues,

To this end, the Government undertakes to:

(a) Support micro-, small and medium-scale agricultural and rural enterprises...

(b) Tackle the problem of smallholdings through:

(i) A firm and sustained policy of support for smallholders so that they can become small-scale agricultural businessmen through access to training, technology, credit and other inputs;

(ii) Promoting, if the smallholders so desire, amalgamation of holdings in those cases where conversion into small businesses is not possible owing to the dispersal and size of the properties (Agreement on the Social and Economic Aspects and Agrarian Situation, 1996: $\mid 36)$.

Smallholdings are considered a problem that needs to be solved through conversion to micro-enterprise via training and technology. Farmers are to become businessmen, and if they are not able to due to the scale of their holdings, the government will assist them to consolidate into economies of scale.

As with land, the subsection on housing emphasises privatisation. There is a need 'to give priority to the building of low-cost housing, through the appropriate financial arrangements, in order to enable as many Guatemalan families as possible to own their own homes' (Agreement on the Social and Economic Aspects and Agrarian Situation, 1996: $\mid 25)$. The financing of new housing would occur with the proper incentives to investors and companies:

Strengthen the securities market and make it more available as a source of funds to purchase housing, by ... facilitating the selling of securities issued for housing operations, such as common and preferred stocks in 
construction companies, mortgage bonds and debentures, real estate participation certificates, supplemental letters, promissory notes and other documents related to rental with an option to buy (Agreement on the Social and Economic Aspects and Agrarian Situation, 1996: $\mid 25(\mathrm{f}))$.

One of the striking things about this passage is the specificity of economic instruments to be employed in financing new housing, no doubt the 'appropriate financial arrangements'. There is no ambiguity about how the goal for low-income housing will be accomplished, the mechanisms involve strengthening the market, commodifying real estate, and providing more financing for construction companies. Then the government will provide subsidies to low-income families to purchase their houses (Agreement on the Social and Economic Aspects and Agrarian Situation, 1996: \25(g)). Thus, housing is constructed to be governed by the market and lucrative to investors, despite the need for subsidies as well: it is a predominantly economic, rather than social, good. (Considering the contingency of social programmes on the 6 percent increase in GDP, this approach seems even more precarious in terms of its ability to actually provide housing to the poor.)

Recalling CACIF's identification of tourism as a 'cluster' of national competitiveness for economic development, the Socio-Economic Accord's treatment of culture in the rural sector reflects Porter's thesis as well. The preservation of culture is seen in economic terms: as something for the state to take advantage of.

These changes [promoting more efficient farming, etc.] will enable Guatemala to take full advantage of the capacities of its inhabitants and, in particular, the richness of the traditions and cultures of its indigenous peoples. It should also take advantage of the high potential for agricultural, industrial, commercial and tourist development of those resources deriving from its wealth of natural resources (Agreement on the Social and Economic Aspects and Agrarian Situation, 1996: |29).

Clearly the implication is that the commercial and tourisitc development of natural resources might also apply to the traditions of indigenous peoples. In the neoliberal 
project, traditions represent a resource for the state to utilise. The state is the guarantor that 'its' inhabitants are utilised as economic inputs. Indigenous peoples 'in particular' are a rich commodity to be developed.

The Socio-Economic Accord relies on conventional neoliberal mechanisms privatisation and the market - for access / distributional issues around land and housing. More subtly and profoundly, perhaps, it aims to reconstruct the social as an expression of the market. It does this at the level of individual subjectivity through the creation of structures that inculcate market rationality in the conduct of nearly all areas of daily life. The citizen-entrepreneur embodies this ideal and becomes the subject of policy-making. Growth and efficiency appear as omnipresent goals. Social goods are consistently constructed in economic terms. Indeed, the rural population is explicitly reorganised for production, and the solution to land reform is the market, which 'promises' growth out of the historical injustices acknowledged in the accords. This order homogenises the diversity of economic relationships to the land into one governed by the rational actor and the market, with the sanctioned marginalisation of groups that 'irresponsibly' do not participate in full. Indeed, 'the richness of the traditions and cultures' of indigenous peoples become commodities.

The Socio-Economic Accord exploits the need to address the social bases of conflict as an opportunity to reconstruct the integral state as a reflection of the market. The raison d'etat becomes the microeconomics of the firm, while citizenship is constructed around the rationality and subjectivity of homo economicus. 


\section{Subjectivity and coercion}

Modernisation and development figure as prominent motifs in the discourse of the Armed Forces and related agreements, reflecting to a certain extent an understanding that continues the aspirations of counterinsurgency if not its methods. The Armed Forces Accord is predicated on the ideas of the weakness of civil institutions, national development and 'the security and full development of the individual' (Agreement on the Strengthening of Civilian Power and the Role of the Armed Forces in a Democratic Society, 1996: preface). The discourse of the development of the individual provides justification for claims such as it is of crucial importance to enhance, modernize and reinforce the State and its republican, democratic and representative system of government' (Agreement on the Strengthening of Civilian Power and the Role of the Armed Forces in a Democratic Society, 1996: \1-2). The function of the new National Civil Police is 'to protect and guarantee the exercise of the rights and freedoms of the individual; prevent, investigate and combat crimes, and maintain public order and internal security' (Agreement on the Strengthening of Civilian Power and the Role of the Armed Forces in a Democratic Society, 1996: $₫ 2-$ 3). And the military education system is to be reformed to be consistent 'with a culture of peace and democratic coexistence' as well as 'with national values, the integral development of the individual, knowledge of our national history, respect for human rights and the identity and rights of indigenous peoples, and the primacy of the individual' (Agreement on the Strengthening of Civilian Power and the Role of the Armed Forces in a Democratic Society, 1996: 140). Thus, demilitarisation is predicated on accepting the primacy of the individual; one of the values of counterinsurgency's embedded modernisation. 
Impunity is mentioned as early as the 1994 Comprehensive Agreement on Human Rights, whose second section, 'Commitment Against Impunity', involves an agreement by the government not to sponsor legislation or other measures to prevent the prosecution of those responsible for human rights violations and to initiate legislation 'so that enforced or involuntary disappearances and summary or extrajudicial executions may be characterized as crimes of particular gravity and punished as such' (The Comprehensive Agreement on Human Rights, 1994: \2). Paragraph 3 stipulates that "No special law or exclusive jurisdiction may be invoked to uphold impunity in respect of human rights violations'. However, in the subsequent agreement on the Role of the Armed Forces impunity is mentioned only once, in the context of the reform of the justice system, which 'should be geared to preventing the judiciary from producing or covering up a system of impunity and corruption' (Agreement on the Strengthening of Civilian Power and the Role of the Armed Forces in a Democratic Society, 1996: 99). The notion of impunity, as noted earlier, is primarily raised in the agreement on the reintegration of the URNG. This accord called for new legislation, a National Reconciliation Act to address both 'the right to know the truth' and 'the right of redress'; $p$ aragraph 20 of the a ccord s tipulates s uch an act s hould promote national reconciliation 'without neglecting the need to combat impunity', although the following sections on political crimes and related common crimes clearly provide wide scope for amnesty. (The Law for National Reconciliation was passed in early 1997.)

Impunity generates certain political subjective effects which are of concern here primarily in terms of their capacity to dissuade political engagement. Impunity is associated with depoliticisation both because the psychodynamics associated with counterinsurgency's techniques of involving the population in its technologies of 
control and because of the 'unreality' of making sense of the experienced world in a climate of denial.

The technologies of counterinsurgency involve actively incorporating the population in strategies of social control. This may be done in terms of forced resettlement and civil patrols, but it is also done through the exercise of spectacle. The use of spectacle occurs within the public-private obfuscation that characterises counterinsurgency, for while it is intended to influence those immediately present, it is also denied by official sources. However, by forcing some to witness the atrocities of counterinsurgency, the perpetrators psychologically involve them in the violence, leading to a sense of shared responsibility. Frank Graziano writes of such spectacles in Argentina, 'The public's collective body, united by and meaningful in relation to the body being brutalised, constituted the agency by which the macabre display was transformed into a ceremonial strengthening of the institutions in which they were now participating' (Zur, 1995: 62). Counterinsurgency implicates the public in its own tyranny as the 'audience-guarantor', forcing it to '[share] the State's power and truth because it [shared] in the spectacle' (Zur, 1995: 62, quoting Graziano). Thus counterinsurgency carries out other forms of social denial in addition to its official denial. Moreover, the continued public denial of counterinsurgency both in terms of truth and accountability reiterates a depoliticised subjectivity.

The public denial of the trauma of counterinsurgency through impunity can lead to a sense of unreality that makes politics next to impossible. The absence of an acknowledgement of trauma, 'pervert the highest mental functions ... the process of learning and knowing, and even that of imagining' such that 'victims do not see truth and justice as feasible' (Rojas, 1999: 20, 17). The symptoms of impunity are highly 
undemocratic: people report 'impotence and frustration, that they did not any longer feel like a whole person with rights' (Rojas, 1999: 27). Dr. Paz Rojas writes of impunity in Chile: 'The appearance of this new symptomatology, whose psychodynamism differed from that of crime, led us to think that, with time, impunity induces mechanisms of intrapsychic perturbation with consequences equal to or worse than torture' (Rojas, 1999: 25-26). From a Gramscian perspective, impunity could be seen as an expression of coercion that threatens to close the potential for the critical dialogue between independent subjectivity and socially constructed subjectivity required to transcend hegemonic understandings of society.

Raúl Molina Mejía describes the political / psychological manifestation of impunity as the technique 'by which political options in a polity are restricted and controlled through the state's manipulation of fear' (Molina Mejía, 1999: 58). He argues that not only does the continuation of coercion through silence preempt demands for social equality and justice generally, but in the case of Guatemala impunity affected the FDNG's support in the 1995 elections. He claims that although voters knew that individual ballots were secret, 'the political inclination of each municipality would be immediately unveiled' (Molina Mejía, 1999: 64). The legacy of counterinsurgency extends beyond its immediate manifestations, where the memory of violent repercussions extends into spheres such as voting behaviour.

In sum, there are two significant features of the resolution of militarism and counterinsurgency from the perspective of p olitical s ubjectivity. One r einscribes the individual as the site of development as a protection from the abuses of counterinsurgency, which does not break from counterinsurgency's fundamental concept of modernisation. Second, the continuation of the logic of counterinsurgency 
through impunity leads to a depoliticisation of the public. This occurs both at the more overt level of an awareness that individual rights may not secure the protection of the collectivity as well as the less visible psychological level, where the 'unreality' of lived and constructed worlds cannot be reconciled.

\section{'Revolution-restoration' in the texts of the accords}

The ethos of this revolution-restoration is the neoliberal modernisation process. Thus the social transformations reflected in the accords reflect a 'revolutionary' dimension to the extent that this modernisation process moves beyond the logic of counterinsurgent modernisation. Yet it reflects a 'restorative' dimension to the extent this project reconstructs society to serve better modernising elite interests constructed under counterinsurgency, without counterinsurgency's contradictory, violent excesses.

The accords reflect an impulse to rework, if largely at the margins, the traditionalmodern dichotomy of disarticulation through the 'reorganisation of the rural population for production'. This impulse favours transforming agrarian capitalism outside of the boundaries of large fincas into what Lenin described as the 'farmer' model of agrarian capitalism, where the peasant becomes the 'agent of agriculture' and evolves into a capitalist farmer (de Janvry, 1981: 107). In principle, such a transition would involve the 'revolutionary' social transformation of a greater proletarianisation of the rural labour force, which would allow for less direct coercion in rural labour relations and the construction of an internal market. ${ }^{150}$ In Guatemala, this logic is applied only at the margins of disarticulation, as it presumes the persistence of large

${ }^{150}$ For these reasons, Lenin thought the farmer model of rural capitalism superior to the Junker model. de Janvry, The Agrarian Question and Reformism in Latin America, 108. 
fincas (which in Lenin's model the farmer model would have displaced) and the modernization of the economy around export-oriented clusters rather than an emphasis on the domestic market. The objective conditions of disarticulation, then, are incompletely resolved in the accords, given the boundaries of the application its 'revolutionary' logic. Indeed, the application of this logic at the margins reflects a greater emphasis on the subjective, rather than objective, dimensions of disarticulation.

The accords do overtly engage with the subjective practices of counterinsurgent disarticulation. The project is one of 'revolution' to the extent that it desecuritises the 'objects' of counterinsurgency through the provision of rights to the 'remainder' of the disarticulated ensemble of social relations: the codification of human and indigenous rights and the reintegration of the guerrilla. However, it is one of 'restoration' in that this resolution of the crisis of counterinsurgency concludes the process of destroying the autonomous bases for indigenous society. The tension of these two dimensions are embodied in the transformation of the 'objective' bases for the traditional from the disarticulated production of agricultural commodities to the commodification of tradition itself. In this movement, traditional culture loses its autonomous subsistenceproductive basis: its 'objective' conditions of existence are relocated to a direct relationship to the disarticulated $m$ arket through the commodification of indigenous culture. The grounds for the preservation of indigenous culture are its attenuated subordination to market culture.

\section{Conclusion}

In its origins, the Guatemalan peace process reflected a need to resolve the contradictions of counterinsurgent modernisation, the resolution of which involves an 
emphasis on the subjective dimensions of counterinsurgency in its reformulation of the nature of disarticulation towards a neoliberal model.

This outcome is the result of ongoing operations of power within the Guatemalan peace process that relied to large extent on international involvement and ultimately privileged a particular elite perspective. Such operations involved the ability to establish the dominant understandings of key elements in the terrain of the negotiations as a reflection of intellectual and moral leadership and, associated with that, the ability to cultivate some degree of consent through the construction and management of civil society and the use of electoral politics.

The social bases of conflict are resolved in the texts of the accords by reconstructing society as a reflection of the market. The texts of the accords involve the devolution of social control through the construction of neoliberal economic subjectivity and the preservation of the subjective coercion of counterinsurgency through impunity. In this reformulation, the 'traditional remainder' of counterinsurgency, indigenous culture, was ultimately subject to attenuation and subordination to the logic of market society as well. This was 'revolutionary' in envisaging a transformation of the subjective dimension of counterinsurgent disarticulation and to a much lesser extent the objective dimension as well, which had genuine appeal for subaltern groups. However, both in terms of the limitation it has vis-à-vis reworking objective conditions of counterinsurgent disarticulation and in terms of its fundamental project of continuing disarticulation through neoliberalism, the project is one of 'restoration'.

The caesarist solution reflected in the accords would not be a stable one, as foreshadowed by the 1995 elections. The FRG in particular would represent an 
organised rejection of the agreements, campaigning to defeat the constitutional reforms associated with the Indigenous Rights and Armed Forces Accords. This has been read as right-wing racism (Jonas, 2000), what here could be understood in terms of the rejection of the idea of addressing the subjective dimensions of counterinsurgency, or the cultural persistence of the need for social control. However, the 'elite-pacted' nature of the negotiations, however, equally produced, in a sense, the FRG's competing caesarist perspective: a distinct resolution of counterinsurgent disarticulation that preserves military counterinsurgency while addressing disarticulation through economic populism.

The Guatemalan peace process, in its resolution of counterinsurgent disarticulation, provides insight into the p ossibility of p eace $\mathrm{p}$ rocesses o perating a s t echnologies of neoliberalism. In the next chapter, this theme and its relationship to the implementation of the accords will be explored. 


\section{Conclusion}

The preceding chapters provided a Gramscian framework for analysis of the Guatemalan peace process, an overview of the ensemble of social relations in conflict and entering the peace process, and an analysis of the peace process itself, the origins and conduct of the negotiations and the resulting texts.

The caesarist solution that emerges from the Guatemalan peace process would not overcome its inevitable initial fragility to become hegemonic, much less to implement fully the accords. However, the nature of the accords' implementation reflects a particular hierarchy of measures, that in association with the peace conditionality of the international financial institutions (IFIs), can be seen as a condition of disciplinary neoliberalism. Incomplete implementation nonetheless reconstructs the terrain of popular resistance around the implementation of the accords, thus enhancing the ethico-political purchase of neoliberalism.

In what follows, the argument developed in the preceding chapters is reviewed, the level and nature of the implementation of the accords is considered, and some reflections on the implications of peace processes in the neoliberal historical bloc have for understanding world order are offered.

\section{Overview of the argument}

The analysis offered here began with the observation that though the Guatemalan peace process has been considered a success by many, such claims have been predominantly problem-solving in nature - located in a set of assumptions that 
maintains the status quo and its associated power relationships - rather than critical, i.e., sensitive to ontological and normative assumptions, historical construction and social transformation. The problematic presented by the success claims, and by the notion of post-conflict reconstruction broadly understood, is that of addressing the social bases or root causes of conflict. This problematic is resolved, according to the success claim, above all through the achievement of a programme of social development, a regime of human and indigenous rights, and democratic participation in Guatemalan politics. In contrast, a critical perspective asks on what grounds such development, rights and participation are constructed.

A Gramscian perspective sees politics in such a critical theoretical vein, in terms of relationships of power and knowledge across the institutional boundaries observed in conventional analyses. Gramscian analysis implies a reformulation of the problematic of addressing the social bases of conflict in terms that recognise the relationship between political and civil society in the 'ensemble of social relations', which may not conform to the boundaries of the state conventionally understood. Such a perspective recognises the historically, materially and subjectively constituted nature of power and its relationship both to coercion and intellectual and moral leadership. This analysis is particularly useful for drawing attention to the operation of power during moments of potential social transformation.

Gramsci understood the institutionalisation of an ensemble of social relations through regimes of coercion and consent, shared ethico-political understandings that unite dominant social groups with subaltern, in terms of the historical bloc. A holistic, critical analysis of post-cold war peace processes recognises the dominance internationally of a neoliberal historical bloc. 
The ensemble of social relations in Guatemala entering the peace process was one of counterinsurgent disarticulation. Here disarticulation refers to the (re)construction of modern / traditional social divisions, and associated race and class hierarchies, to maintain conditions of semiproletariat labour (including below market wages) associated with export-oriented plantation agriculture. Thus disarticulation is associated both with 'objective' economic conditions and 'subjective' social conditions that justify such hierarchies. Guatemala can be described as disarticulated from the generalisation of coffee cultivation. The reform decade of 1944-54 addressed some features of disarticulation, but not capitalism per se. It precipitated US involvement based on perceived economic concerns as well as understandings of the racialised and militarised ensemble of social relations associated with disarticulation as desirable for modernisation. This involvement supported local agricultural and military elite interests, which together constructed a counterinsurgent state.

Counterinsurgency is predicated on elite-oriented models of development, where the 'residual' social elements of disarticulation - the 'traditional' and associated social categories - are understood to be a potential threat to modernisation. The counterinsurgent period in Guatemala reflected significant international involvement both in terms of the 'intellectual and moral leadership' behind theories of counterinsurgency and in the (re)construction of society in a particular modernisation ideal. The construction of the counterinsurgent state is accompanied by a restructuring of the economy towards activities more integrated with transnational capital: banking, non-traditional agricultural exports, maquila finishing and tourism. 
The Guatemalan peace process emerges from a crisis of the counterinsurgent state: the internal financial crisis of the cost to elites and the external crisis of international concerns about Guatemala's human rights abuses. These crises led on the one hand to a return to civilian rule and on the other to participation in the Central American regional peace processes. The regional efforts would construct certain parameters for the Guatemalan peace process, particularly the privileging of electoral democracy as the expression of democratic participation. Guatemala's peace process used civil society to cultivate consent while engaging in a strategy of deferring 'essential' questions until after the 1995 elections. Such moves led to an attenuation of popular demands and the construction of rights as entirely political, to the exclusion of the economic. The appeal to electoral democracy, while constructed around polyarchic principles for preserving elite privilege, in fact resulted in exposing elite divisions. Thus the post-1995 election period, when 'the essential' - the military and the economic - is resolved, reflects a caesarist resolution of the crisis of counterinsurgent disarticulation involving the international community, modernising economic elites represented by the PAN, and the URNG.

Caesarism - the r eassertion of e lite p ower in a novel 'revolution-restoration' of the social order - captures the way in which the social bases of conflict are indeed opened up for negotiation, though resolved through plans for a reorganisation of society that ultimately restores elite privilege. The blueprint for this reorganisation of society involves an appeal to participation in the post-conflict state, the provision of rights, social investment, and demilitarisation. However, these social 'goods' as understood in the texts of the accords reflect a neoliberal social order that divorces economic issues from political rights, uses social investment to construct a neoliberal economy and subjectivity, and relocates coercion from direct militarism to a system of police. 
The peace process in Guatemala aimed constructed a state suited to the post-Cold War neoliberal o rder. The s tate $\mathrm{w}$ as r econstructed to p rovide g reater s ecurity for $\mathrm{c}$ apital, and as, as per Foucault's observation in Chapter 2, an enterprise 'to universalize competition and invent market-shaped systems of action for individuals, groups and institutions' (Lemke, 2001: 197). The entirety of the ensemble of social relations becomes subordinate to market logic, through a project of reorganisation that involves the reconstruction of homo economicus under a particular self-entrepreneurial subjectivity and the commodification of indigenous culture.

\section{Caesarism, implementation, and neollberalism's ethlco- political purchase}

The fragility of the caesarist solution to the peace process is reflected in the very limited and uneven implementation of the accords. Implementation reflects the common denominator of the two caesarist resolutions to the crisis of counterinsurgent disarticulation - the initially successful PAN/URNG/international solution and the FRG's populism - the need to secure the guerrilla. Thus, the operational accords, dealing with a definitive ceasefire, the demobilisation of the guerrilla, and the return of refugees, were for the most part implemented very quickly (Salvesen, 2002: 9). In principle, all of the accords were to be implemented by December 2000, however this timetable was revised in December 1999 to extend until 2004; the rescheduled agenda included 119 outstanding commitments predominantly relating to the Socio-Economic Accord (66), the Armed Forces Accord (23) and the Indigenous Accord (18) 
(Salvesen, 2002: 9). ${ }^{151}$ One of the most conspicuous obstacles to implementation is the electoral defeat of constitutional reforms necessary for the full implementation of the Indigenous Rights and Armed Forces Accords; taxation has also remained a persistent question, generating a new set of civil society negotiations around a Pacto Fiscal (fiscal pact). ${ }^{152}$

Perhaps the most fundamental failure of implementation involves the defeat of the constitutional reforms required by the Agreement on Constitutional Reforms and the Electoral Regime, and associated with key elements of the Armed Forces and Indigenous Rights Accords. ${ }^{153}$ The PAN embroiled the reforms in a complicated process that added numerous extraneous elements to the package and delayed their consideration, making them vulnerable to numerous challenges from a well-organised

${ }^{151}$ The interim targets for these commitments for 2004 largely do not seem to be met. MINUGUA, 'Executive Summary: MINUGUA Report to the Consultative Group meeting for Guatemala', (Guatemala: MINUGUA, 2003).

${ }^{152}$ To date, MINUGUA has written numerous reports on the implementation of the accords: 16 specifically on the accords, 14 on its human rights missions, and approximately 18 others on related issues. This section relies significantly on the more recent MINUGUA reports on indigenous rights (MINUGUA, 'The Indigenous Peoples of Guatemala: Overcoming Discrimination in the Framework of the Peace Agreements', (Guatemala: 2001)), on the armed forces agreement (MINUGUA, 'Status of the Commitments of the Peace Agreements Relating to the Armed Forces', (Guatemala: 2002)), and its reports for the Consultative Group meetings (discussed further below); MINUGUA, 'Report for the Consultative Group meeting for Guatemala', (Guatemala: MINUGUA, 2002); MINUGUA, 'Executive Summary: MINUGUA Report to the Consultative Group meeting for Guatemala', . Susanne Jonas provides the most extensive discussion of the defeat of the constitutional reforms and is therefore relied upon heavily in that discussion. Jonas, Of Centaurs and Doves: Guatemala's Peace Process. The URNG has also created its own reports on implementation: URNG, 'Balance del Processo de Paz 1997-1999', (Guatemala: URNG, 1999); URNG, 'Cumplimiento de los Acuerdos de Paz: Abril -Diciembre 1997', (Guatemala: URNG, 1998).

${ }^{153}$ Implementation has been at best partial from 1996 to the present, thus the impact of the 2000 elections that saw the defeat of the PAN by the FRG should not be overstated. Nonetheless, the defeat of the PAN does reflect the inability to consolidate the peace process agenda in the face of caesarist instability. The FRG won the 1999 election by a margin of 68 to 32 percent James Buchanan, 'Guatemala Under the FRG: Peace at a Crossroads', (Ottawa: Canadian Foundation for the Americas, 2000), 4. 
and well-funded anti-reform campaign. ${ }^{154}$ The reforms were ultimately defeated, 56 percent to 44 percent, in a poll marked by very low voter turn out: 18.5 percent of registered voters (MINUGUA, 2002: 2). The negative result has been described in terms of a 'punishment vote' against politicians for the lack of transparency in the development of the reforms in Congress and a reflection of distrust of the political elite (Jonas, 2000: 203, Salvesen, 2002: 22). In addition, confusion about the complexity of the reforms may have affected the outcome: for example, new proposals added questions of municipal authority to demilitarisation reforms such that the indigenous mayor of the second largest city in Guatemala opposed the measures, effecting the overall 'No' vote there (Jonas, 2000: 204).

By the time of the poll, both the PAN and the FRG officially supported the reforms, however, with dubious sincerity. The PAN, as noted, clearly had not taken an active leadership position on quickly achieving reforms, despite their Congressional majority (with the argument that it needed to establish the legitimacy of the reforms with the FRG to ensure that it would not sabotage them during the referendum), nor did it actively promote the reforms closer to the referendum (Jonas, 2000: 190, 95). The FRG decided to support the reforms in early April, 'for opportunistic political reasons' (Jonas, 2000: 195). Jonas suggests that 'many believed, in fact, that both were

The Agreement required that the government propose draft constitutional amendments to Congress within 60 days of its entry into force (which occurred with the final Agreement on a Firm and Lasting Peace on 29 December 1996). The proposals were finally forwarded to Congress in May 1997, subject to negotiation in Congress until October 1998, and then put to a national referendum in May 1999, an election year. Initially the FRG, which would later ostensibly support the reforms, argued that the measures could not be dealt with in Congress but required a full National Constituent Assembly, a position that Susanne Jonas argues was taken in bad faith Jonas, Of Centaurs and Doves: Guatemala's Peace Process, 190. Opponents of the reforms also took their case to the Constitutional Court, which ruled on procedural grounds in February 1998 that the reforms were unconstitutional, sending them back to Congress Jonas, Of Centaurs and Doves: Guatemala's Peace Process, 194. 
engaging in a kind of "double discourse" with their formal " $S$ "' masking indifference and internal divisions (PAN) or opposition (FRG)' (Jonas, 2000: 195). The left assumed that the reforms would pass and, preoccupied with the elections that year, did not mobilise for the cause (Jonas, 2000: 195). The 'No' campaign involved scare mongering around ideas of 'social chaos' and the 'balkanisation' of Guatemalan into two countries (Jonas, 2000: 196-8).

The defeat of the constitutional reforms included the defeat of an amendment to redefine the remit of the military to limit it exclusively to the external defence of the country. In June 2000, a decree further compromised this element of the peace process by formalising the military's role in internal security (Salvesen, 2002: 10). Implementation of the creation of a new military doctrine had not been achieved by 2002 (Salvesen, 2002: 10). There has been a failure to redeploy military detachments in areas of severe counterinsurgency activities, such as the Ixil triangle, and to reconstruct military education and training away from counterinsurgency doctrine and towards a meaningful appreciation of human rights (MINUGUA, 2002: 19-21). While the military budget seemed to meet its target in 1997 and 1998 its proportion of GDP has been creeping beyond the 0.66 percent ceiling in the peace accords since 1999 . The figure was 0.83 percent by 2000 and 0.94 percent by 2001 as the result of supplementary transfers to the Defence Ministry, which increased the Congressionally approved allocation by 85 percent (MINUGUA, 2002: 19).

As with the redefinition of the role of the military, the redefinition of the Guatemalan nation as multi-ethnic, multicultural and multilingual was defeated with the failure of the constitutional reforms. Very few measures of the Indigenous Rights accord have been achieved beyond those calling for the creation of commissions for further study, 
leading MINUGUA to conclude in January 2002 that the Indigenous Rights accord has been the least implemented (Salvesen, 2002: 14-15); (MINUGUA, 2002: 6). All commitments pertaining to land in the Indigenous Rights accord (having to do with title and legal protections) were rescheduled for lack of compliance (MINUGUA, 2001: 25-26). The biggest success in the implementation of this accord is understood to be the creation of Joint Commissions of government and indigenous representatives (MINUGUA, 2001: 30). Yet the Joint Commissions have not had substantive impact: their only accomplishments have been the drafting of further proposals, which has tarnished their credibility with indigenous organisations (Raymundo, 2001).

Regarding the Socio-Economic Accord, most attention has been focused on the challenge of implementing the measures associated with the area of modernisation and fiscal policy. The accords sought to increase taxation from 8 percent to 12 percent of GDP by 2000 . By 1997 it was clear that the government was not going to meet the interim target of 10 percent by 1998 , the commitment was rescheduled and (re)solved through a complex negotiation between civil society and the PAN government resulting in a new Pacto Fiscal (fiscal pact). ${ }^{155}$ In anticipation of the October 1998 meeting of the Consultative Group of international donors to the peace process, the government sought to reschedule its taxation targets. This led to set of n egotiations involving n umerous c ivil s ociety organisations, including C ACIF, around the Pacto Fiscal, which lasted until May 2000 and rescheduled the 12 percent target until 2002

${ }^{155}$ The PAN government did attempt to create a more progressive property tax in late 1997, however, such measures were subject to a confused campaign of resistance. There were widespread protests against the tax (Impuesto Unico Sobre Inmuebles, IUSI) in 1998, supported not only by the FRG but also by rural mayors who felt they would pay the political costs of higher taxes while the wealth would remain with the central government Gamboa M. and Trentavizi, La Guatemala Posible: La Senda del Pacto Fiscal, 20 Jonas, Of Centaurs and Doves: Guatemala's Peace Process, 171-2. 
(also not met) (Gamboa M. and Trentavizi, 2001: 149); (Salvesen, 2002: 17); (MINUGUA, 2002: 14). The primary tax measure that has been implemented involved raising the value added tax (VAT) from 10 to 12 percent. The successes of implementation in the area of fiscal policy involve the creation of 'information systems' for the surveillance of income and public spending. The tax administration (Superintendencia de Administración Tributaria, SAT) established an information sharing s ystem to c oordinate independent $\mathrm{b}$ anks and the central $\mathrm{b}$ ank in m onitoring income (Salvesen, 2002: 17). The SAT has also implemented the requirement for a Unified Tax Register to monitor compliance with tax obligations and a system of evaluation and control of public spending, the Integral System for Financial Administration (SIAF) has been established (Salvesen, 2002: 17).

At the end of the Guatemalan peace process a Consultative Group (CG) was created among key funders of the implementation of the accords, including the World Bank, the Inter-American Development Bank, other international organisations, and bilateral donors. The CG met in January 1997, just after the signing of the final accords, and pledged US\$1.9 billion in aid for the process. Indeed, the actual contribution for the period 1996-99 reached US\$2.4 billion (Salvesen, 2002: 29). By December 2001, the total value of external assistance amounted to US\$3.2 billion, of which 78 percent came from multilateral agencies (Inter-American Development Bank, 2002: 1). The IFIs and the EU provided 81 percent of the multilateral funding, that is 63 percent of the external resources for financing the peace agreements (Inter-American Development Bank, 2002: 2). The US also represents a significant player, providing 45 percent of bilateral aid and about 10 percent of the overall amount. (For specific contributions, see the chart below.) Jonas suggests that the IFIs were inspired to give particular attention to Guatemala because of the perception that Guatemala had in 
recent years prudently managed its macroeconomic affairs so that the implementation of the peace accords could be an opportunity for poverty reduction without macroeconomic instability (Jonas, 2000: 170).

\begin{tabular}{|c|c|}
\hline Agency or Country & $\begin{array}{c}\text { Total Signed } \\
\text { (Thousands of US\$) }\end{array}$ \\
\hline Bilateral & $735,340.1$ \\
\hline Germany & $140,700.0$ \\
\hline Spain & $16,442.4$ \\
\hline Canada & $28,379.2$ \\
\hline Denmark & $7,076.2$ \\
\hline Finland & $8,438.9$ \\
\hline Italy & $12,918.4$ \\
\hline Netherlands & $14,224.4$ \\
\hline Japan & $73,954.5$ \\
\hline Norway & $37,622.0$ \\
\hline United Kingdom & $19,960.1$ \\
\hline Sweden & $29,771.3$ \\
\hline Switzerland & $13,331.6$ \\
\hline United States & $332,521.2$ \\
\hline Multilateral & $2,479,590.2$ \\
\hline $\begin{array}{l}\text { Central American Bank for } \\
\text { Economic Integration }\end{array}$ & $543,254.0$ \\
\hline European Union & $145,675.4$ \\
\hline World Bank & $329,295.3$ \\
\hline $\begin{array}{l}\text { Inter-American Development } \\
\text { Bank }\end{array}$ & $990,516.0$ \\
\hline $\begin{array}{l}\text { Organisation of American } \\
\text { States }\end{array}$ & $11,257.0$ \\
\hline UN Development Programme & $328,860.0$ \\
\hline Other UN agencies & $130,732.50$ \\
\hline TOTAL & $3,214,930.3$ \\
\hline
\end{tabular}

The CG is seen as a strong example of 'peace conditionality' - 'the use of formal performance criteria and informal policy dialogue to encourage the implementation of peace a ccords and the consolidation of p eace' (Boyce, 2002: 1 025-6) - p articularly vis-à-vis taxation. Donors formally and explicitly stated the conditions of their assistance at the outset of the post-conflict reconstruction period, based primarily on 
the increase in fiscal revenues from 8 to 12 percent by 2000 (Salvesen, 2002: 29). The conventional reading of this conditionality is that the aid pledged at the January 1997 CG meeting was to be a temporary measure to assist the peace process, which in principle would ultimately become domestically s ustained through greater taxes and spending on social programmes (Jonas, 2000: 170). However, peace conditionality visà-vis Guatemala has not been contingent on a progressive understanding of taxes and, as noted above, one of the most tangible areas of increases taxes is in the regressive VAT

The PAN did not successfully move beyond the fragility of caesarism to build a hegemonic project around the construction of neoliberalism as implied by the accords. The pattern of implementation nonetheless reflects a hierarchy of neoliberal interests. In addition to securing the guerrilla, implementation has emphasised taxation and the surveillance of banking and public finance. These concerns reflect the logic of disciplinary neoliberalism as Stephen Gill describes it: the use of surveillance to affect conformity in fiscal policy under the IFIs and other elements of the G7 nexus and the (re)construction of taxation to extend it more broadly and regressively, privileging capital and increasing the burden on the lower classes (Gill, 1995). The former expresses the need for elites to reproduce the neoliberal transnational bloc while the latter institutionalises unequal economic hierarchies under the guise of an 'activist tax state' that nevertheless relies upon increasingly regressive taxes (Gill, 2003: 135-7). The importance placed on fiscal restructuring is reflected in peace conditionality. While the conceptual redefinition of the state vis-à-vis militarism and multiculturalism in the constitutional reforms is left to the uncertain fate of the electoral process, the fiscal reconstruction of the state vis-à-vis taxation and the creation of surveillance for 
the protection of international capital becomes an area of international pressure and peace conditionality.

The ethico-political rationale for taxation appeals to the necessity of funding for the implementation of social services agreed to in the accords and indeed the sense that such an approach could in the process redistribute wealth and power in Guatemala (Jonas, 2000: 169-70). However, as taxation is discussed in the Pacto Fiscal and as the basis for peace conditionality on one hand, the Integral System for Financial Administration for the 'evaluation and control of public spending' is established on the other, ensuring state spending within the boundaries of the values implied by neoliberal restructuring, i.e., the insulation of economic oversight from democratic decision-making (Gill, 2003: 132). The emergence of a problematic around the need to increase taxation to create sustainability in the domestic funding of the peace accords obscures the strategic nature of the selective implementation of taxation and financial surveillance mechanisms.

Furthermore, partial implementation has reconfigured popular movements towards pressing for implementation above critical analysis of the nature of the accords themselves, reiterating the 'end of the revolutionary option'. The accords have become seen by many as the best option demilitarisation and multiculturalism, establishing neoliberalism as the horizon of 'common sense' progressive politics. Thus to the extent that the implementation of the accords now defines the parameters of social struggle, neoliberalism's ethico-political project gains credibility. For example, in an analysis of the December 2003 run-off elections in Guatemala, left commentator Simon Helweg-Larson argues in terms of the 'progressive development' of implementing the peace accords (Helweg-Larson, 2003). 


\section{Implications of a Gramscian analysis of the international politics of post-conflict reconstruction in Guatemala}

Gramscian analysis is particularly suited to analyse critically peace processes because of its emphasis on the operation of power within 'consensual' arrangements, which are above all the premise of such negotiations. Related to that, the Gramscian emphasis on the technologies of power for co-opting openings for social change is particularly suited to analysing the apparent populist assertion of right-wing politics in such circumstances: in his own analysis, the rise of fascism in Italy, and in the case of Guatemala, the failure of the peace process to maintain popular support through implementation. In the case of peace processes, as Guatemala illustrates, the failure of such caesarist solutions to establish hegemony in the short term may not threaten the elite project it implies, and indeed my endow such solutions with greater ethicopolitical purchase, improving the longer term prospects for such programmes. Of course this outcome relies on the ethico-political purchase of the notion of peace itself, which is established in the post-Cold War era through the 'end of the revolutionary option'.

The case of Guatemala underscores that understanding peace processes through a Gramscian lens that implies an understanding of world order, for which the analysis must examine not just neoliberalism, but post-Cold War neoliberalism. This reflects the particularities of the position of developing countries in world order, a condition that Robinson is right to suggest remains undertheorised by Gramscian IPE. For although the global transition to neoliberalism equally influences the ensemble of social relations in Guatemala in the ascent of non-traditional sectors of the economy and the r ise of modernising e lites associated w ith C ACIF v is-à-vis m ore traditional 
economic elites, this does not lead immediately towards a neoliberal peace process. Cold War politics associated with Ronald Reagan - with Margaret Thatcher the most vivid architect of radical neoliberal deregulation - amplified the logic of counterinsurgency before it became subject to such resolution. The logic of the 'end to the revolutionary option' could only occur after the end of the Cold War. However, it is also true that though there is a universalising impulse to neoliberal intellectual and moral leadership as established through multilateral organisations, as a world order it does not require that all states operate with the same guarantees for capital, it merely disciplines through access to finance those that do not. The move from counterinsurgency reflects the drive by Guatemalan elites to compete within the neoliberal world economy as much as the imposition of a peace process by the international community.

Peace processes can be effective technologies for neoliberalism in several ways. As noted above, negotiations engage in the practice of cultivating consent, but as discussed in Chapter 3, under third party mediation may extract 'consent' from different parties to keep the momentum of the discussions going with the promise of future participation. Furthermore, peace processes that address the social bases of conflict represent the opportunity to restructure the state: this may be a desirable goal depending on the nature of the ensemble of social relations, but the appeal to such a necessity gives powerful interests greater scope to (re)construct the social structures of the ensemble of relations. Finally, the ethical purchase of peace and the existential threat of a return to violence together operate to justify certain kinds of changes towards a neoliberal order: for example, it encourages the devolution of social control from the military to the police. Similarly, it supports the 'pragmatic' adjustment of the national economy to the global economy to facilitate the urgent need for post-conflict 
reconstruction, subordinating national policies to the logic of international organisations through p eace c onditionality. These policies a re underwritten $w$ ith the appeal to peace as a normative good in the era where the revolutionary option is understood to be obsolete.

Nonetheless, the implications a critical Gramscian analysis of peace processes have for the study of world order involve, among other things, appreciating the ethico-political purchase neoliberalism has in certain settings. This moves beyond an appreciation of the political subjective dimension of neoliberalism, which is so often missed, but appreciating that the impulse to devolve social control to the individual and the universalise competition in settings of very unequal privilege appear as genuinely progressive options, much as the move to capitalism was embraced in the reform era in Guatemala: Though aware of the novel features of the ethico-political rationales animating this world order, Gramscian analysis remains critical about nature of such discipline, in particular the 'totalising' effects it could imply for such a politics.

To that end, a Gramscian analysis of post-Cold War peace processes can illuminate the 'common sense' understandings within the 'international community' of industrialised states and multilateral institutions about post-conflict reconstruction plans. The case of Guatemala, now taken to be an archetypal case in such efforts, likewise underscores to Gramscian IPE the necessity of an analysis that better incorporates raisons d'etat in the periphery, and the fruitfulness of more rigorous engagement between IPE and related fields that have also engaged in Gramscian analyses. 


\section{Appendix 1: Political Chronology of Guatemala ${ }^{1}$}

1821 Guatemala declares independence from Spain.

1822 Central America annexes itself to Mexican Empire.

1823 Central America declares independence from Mexico and forms United Provinces of Central America.

1824 Central American states ratify republican constitutions.

1826 Central American governments sign Treaty of Friendship and Commerce with United States.

1826-29 Bloody civil war in Guatemala between Liberals and Conservatives.

1829 Liberals emerge victorious in Guatemala.

1831-38 Liberal Mariano Gálvez launches bold liberal and anticlerical policies.

1837-40 Cholera epidemic in Central America.

1839 Conservative Rafael Carrera comes to power in War of the Montaña.

1839-42 Liberal program dismantled.

1847 Guatemala declared a Republic.

1848 Carrera resigns in face of popular uprising.

1849 Carrera returns to power as armed forces chief. Mariano Paredes is officially President until 1851.

1854-65 Carrera serves as Perpetual President of Guatemala.

1865 Carrera Dies.

1871 Conservative leader General Vicente Cerna overthrown by Liberal revolt.

1873 Liberal Justo Rufino Barrios becomes dictator of Guatemala.

1885 Barrios killed in El Salvador.

1898 President José M. Reyna assassinated.

1898-1920 Manuel Estrada Carbrera seizes power and establishes dictatorship.

1899 United Fruit Company formed.

1921 Guatemalan "Unionist" government overthrown by military.

1931-44 Dictatorship of Jorge Ubico.

$1944 \quad$ Ubico resigns in face of protests.

1945 New Constitution ratified.

1945-50 Juan José Arévalo leads reformist administration.

1949 Francisco J. Arana assassinated, and revolt of Guardia de Honor follows.

1950-54 Jacobo Arbenz elected President of Guatemala.

1952 Agrarian reform law goes into effect. Guatemalan Labor Party (PGT) formed.

1954 Carlos Castillo Armas overthrows Arbenz with aid of US.

1957 Castillo Armas assassinated.

1958 Common market plan developed and treaty signed.

1958-63 Conservative Migeul Ydígoras Fuentes elected President.

1960 Leftist revolt suppressed. Survivors form MR-13 guerilla movement.

1963 Military, led by Minister of Defense Enrique Peralta Azudia, ousts Ydígoras and pursues hard-line against leftists.

1975 Guerilla Army of the Poor (EGP) launches guerilla activity in northern Quiché Department.

\footnotetext{
${ }^{1}$ Sources: Ralph Lee Woodward Jr., Central America: A Nation Divided, 3rd ed. (New York: Oxford University Press, 1999). Jeremy Armon, Rachel Sieder, and Richard Wilson, eds., Negotiating Rights: The Guatemalan Peace Process, 2 ed. (London: Conciliation Resources, 1997).
} 
1977 Guatemala rejects US military aid when Jimmy Carter links it to greater human rights observance.

1978 General Fernando Romeo Lucas García becomes President in fraudulent election. Escalates repressive policies. Rejuvenated Rebel Armed Forces (FAR) renew guerilla activities.

1981 US resumes arms sales to Guatemala.

1982 Guatemalan Military coup in March ousts General Lucas and installs a junta headed by General Efraín Ríos Montt. Ríos Montt assumes Presidency on June 9. Guatemalan National Revolutionary Unity (URNG) formed as umbrella group for rebel groups.

1983 Military coup in August ousts Ríos Montt and installs Defense Minister Oscar Humberto Mejías Victores.

1985 Military agrees to elections.

1986 Civilian rule re-established with inauguration of Vinicio Cerezo. Oscar Arias elected President of Costa Rica.

1987 Esquipulas II Peace Agreement signed.

1988 URNG meets with National Reconciliation Commission established by Esquipulas II.

1990 Msgr. Rodolfo Quezada Toruño becomes official 'conciliator' of emerging Guatemala peace process, UN Secretary General invited to observe. URNG meets with other sectors of society.

1991 Jorge Serrano Elías elected President. Mexico Accord signed.

1993 Serrano attempts 'auto-golpe'. Instancia Nacional de Consenso (National Consensus Body, INC) resolves crisis, installs Human Rights Ombudsman Ramiro de León Carpio as President.

1994 Civil Society Assembly (ASC) formed. Five peace accords signed.

1995 Indigenous Rights Accord signed. Alvaro Arzú of the PAN party wins December elections by a two percent margin.

1996 Eight peace agreements signed, including the final peace accord, 'The Agreement on a Firm and Lasting Peace', on 29 December. 


\section{Appendix 2: Maps of Guatemala ${ }^{2}$}

\section{Economic regions}

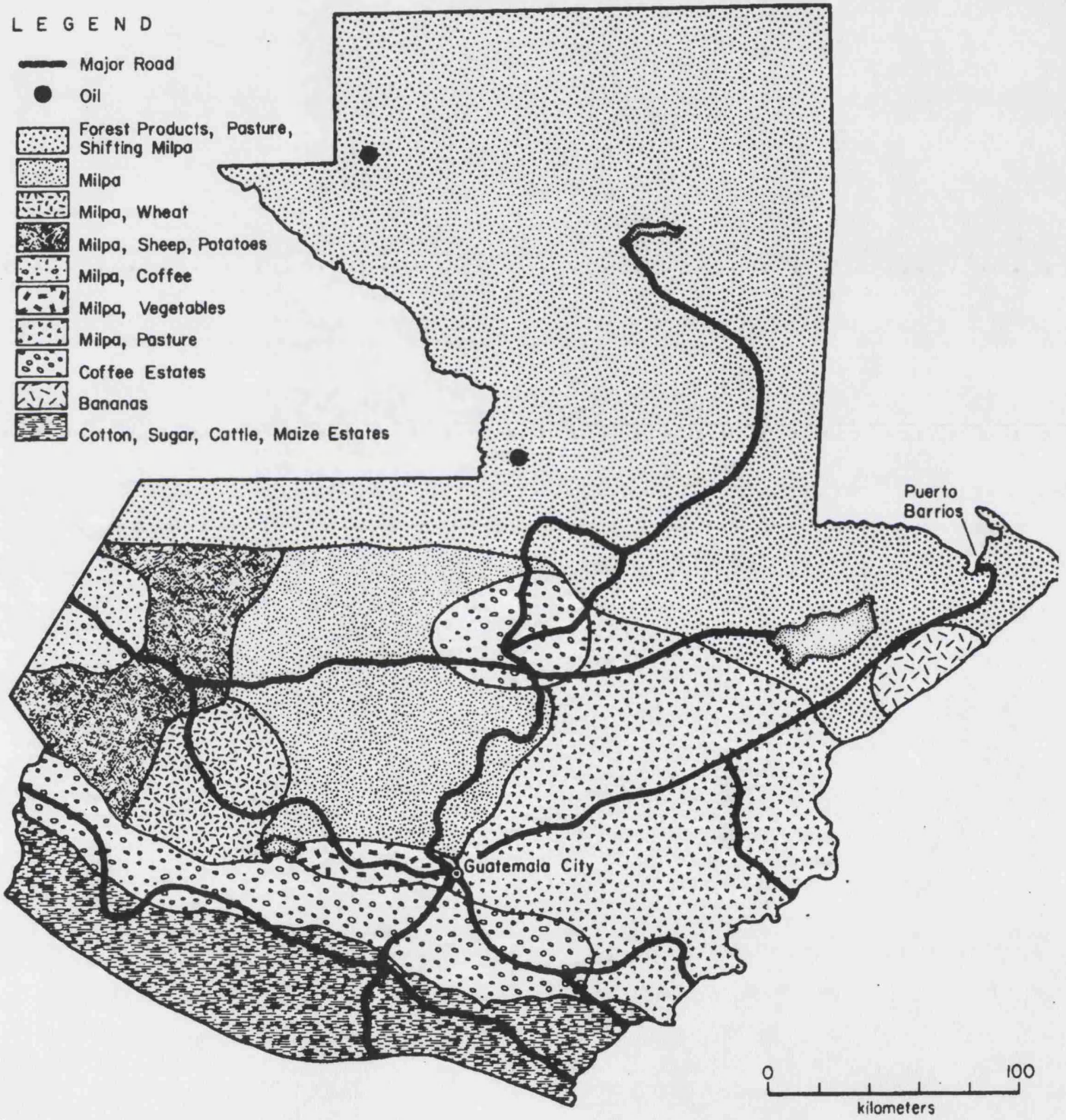

\footnotetext{
${ }^{2}$ Source: Carol A. Smith, ed., Guatemalan Indians and the State, 1540 to 1988 (Austin: University of Texas Press, 1990), 9-11.
} 


\section{Insurgent regions}

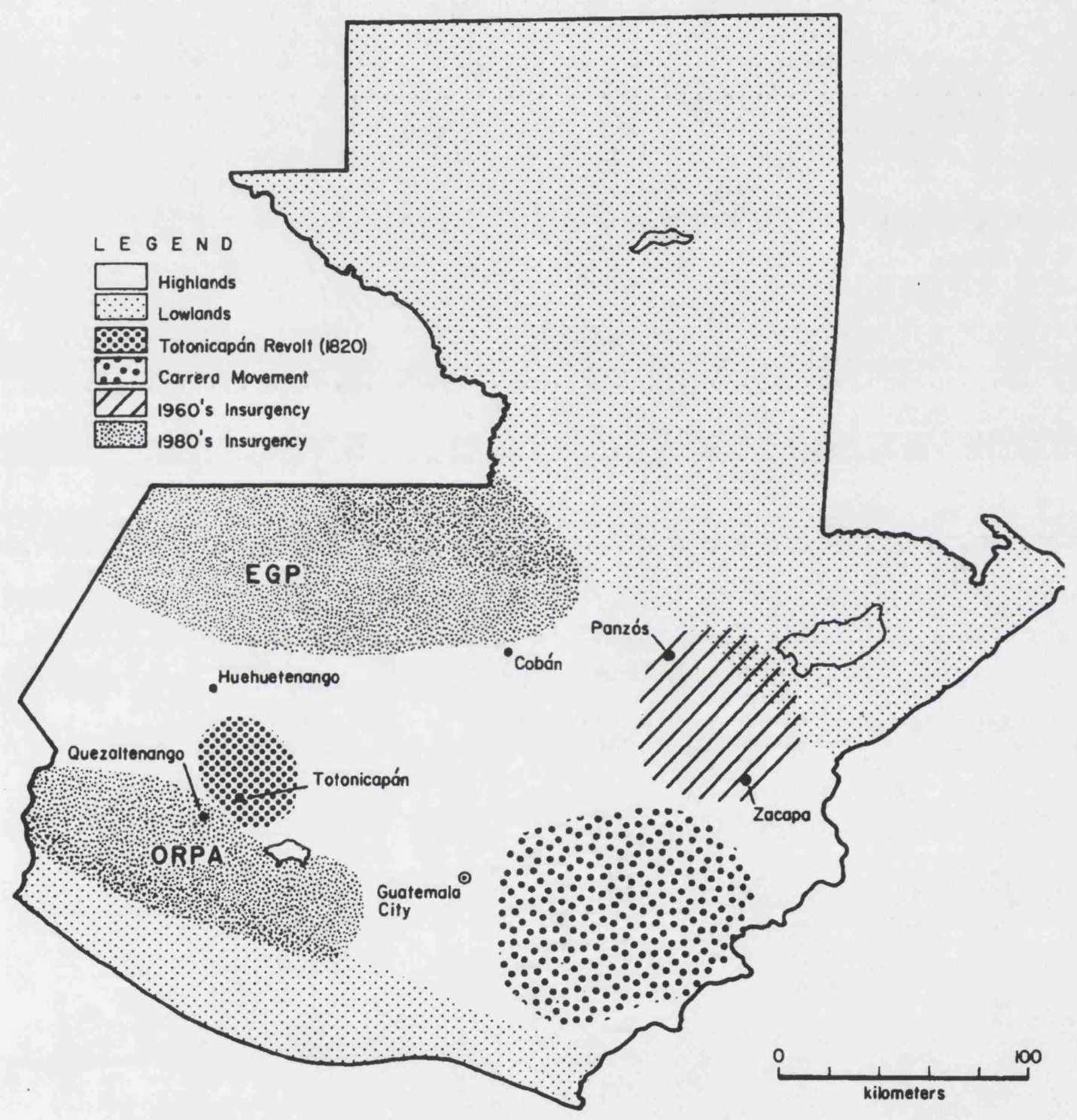




\section{Major towns and departments}

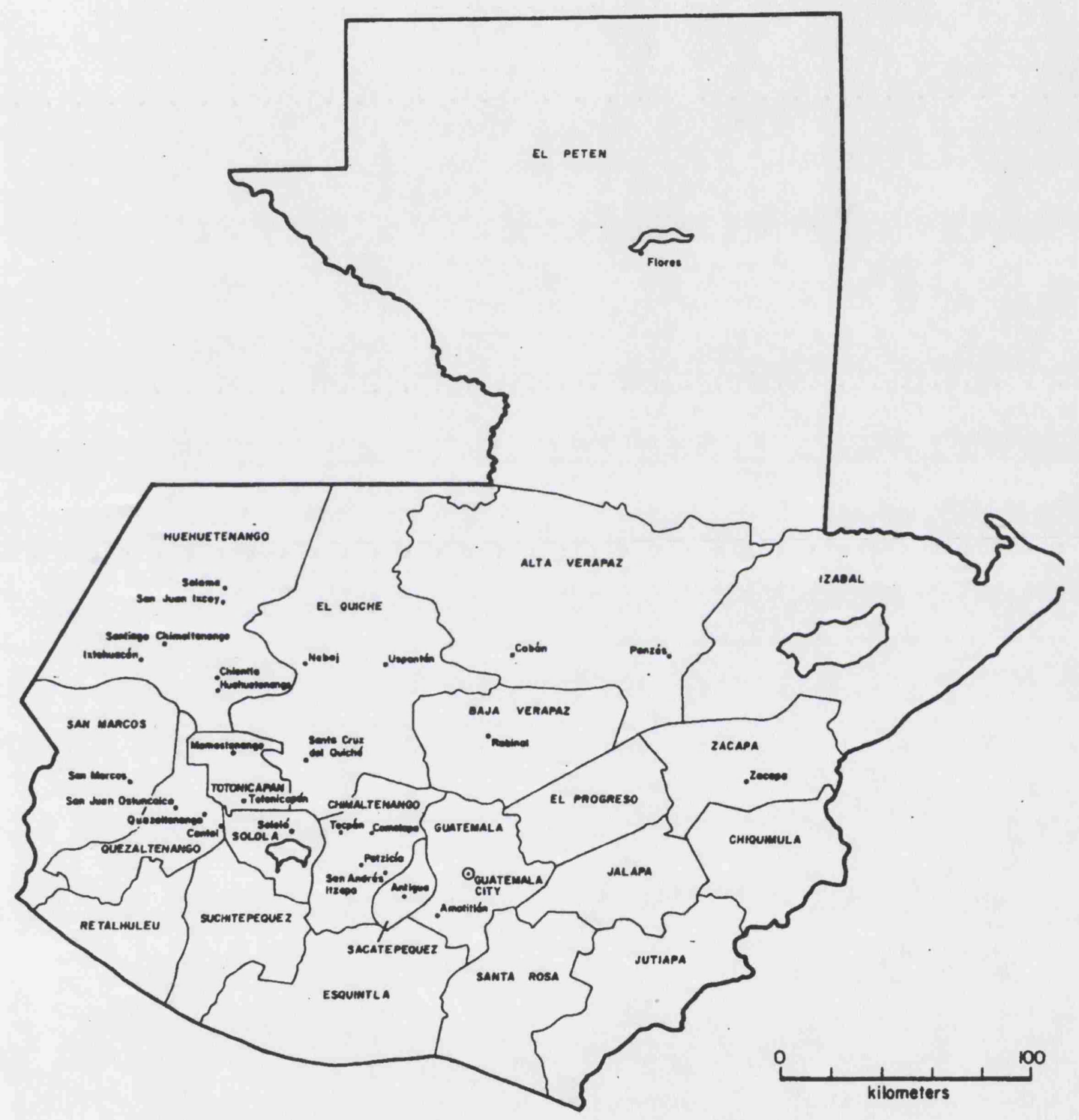




\title{
Appendix 3: Text of the Socio-Economic Accord
}

\author{
Agreement on Social and Economic Aspects and Agrarian Situation
}

\begin{abstract}
THE SITUATION IN CENTRAL AMERICA: PROCEDURES FOR THE ESTABLISHMENT OF A FIRM AND LASTING PEACE AND PROGRESS IN FASHIONING A REGION OF PEACE, FREEDOM, DEMOCRACY AND DEVELOPMENT
\end{abstract}

Letter dated 24 May 1996 from the Secretary-General addressed to the President of the General Assembly

I have the honour to transmit herewith the text of the Agreement on Social and Economic Aspects and Agrarian Situation, concluded on 6 May 1996 between the Presidential Peace Commission of the Government of Guatemala and the General Command of the Unidad Revolucionaria Nacional Guatemalteca (URNG) (see annex). The signing ceremony took place at the Mexican Foreign Ministry in the presence of Mr. Angel Gurría, Foreign Minister, and, amongst others, senior officials of the countries that are members of the Group of Friends of the Guatemalan Peace Process (Colombia, Mexico, Norway, Spain, the United States of America and Venezuela), representatives of the Assembly of Civil Society and other Guatemalan personalities.

This Agreement, which is the fruit of intensive negotiations initiated a year ago, contains a comprehensive package of commitments on several issues critical to the building of a lasting peace and sustainable development in Guatemala. Based on a shared perception that conflict resolution is inseparable from significant change in social and economic policy, the parties have agreed on a broad array of measures to permit wider participation in decision-making at all levels; to increase and redirect government spending towards social development; to promote a more efficient and equitable agrarian structure; to modernize public administration; and to produce a sustained increase in public revenue. At the heart of the strategies outlined in the agreement is the concept, consistent with the thinking of the United Nations, that enhanced social participation in all aspects of development is key to both improved social justice and sustainable economic growth. The Agreement reflects an agenda of social and economic change widely supported in Guatemala. On 22 May 1996, the text of the Agreement was submitted to the Assembly of Civil Society for its endorsement.

With the signing of the Agreement on Social and Economic Aspects and Agrarian Situation, the peace process in Guatemala is gathering new momentum. The cessation of offensive military action declared by both parties in March has held. The suspension by the URNG of its practice of levying "war tax", with effect from 6 May, will broaden support.for the peace process within Guatemala. Advances in the negotiations will, in turn, facilitate the difficult struggle against impunity to which the Government of President Arzú is committed. Better prospects for an early peace will also enhance the impact and effectiveness of the verifying and institution-building activities of the United Nations Mission for the Verification of Human Rights and of Compliance with the Commitments of the Comprehensive Agreement on Human Rights in Guatemala (MINUGUA). In a public statement dated 6 May 1996, I congratulated the parties on their achievements and encouraged them to build upon those positive developments as they considered the next item on the negotiating agenda, namely, "Strengthening 
civilian p ower and the role of the army in a democratic s ociety". This process will begin on 7 and 8 June 1996 in Mexico City.

The Agreement will enter into force with the signing of the Agreement on a Firm and Lasting Peace, which is to be the culmination of negotiations held under United Nations auspices since January 1994. At the request of the parties, and subject to authorization by the appropriate United Nations organ, MINUGUA will then expand its activities to cover verification of all agreements reached. While the latter's comprehensiveness will make verification a particularly complex task, experience has shown that the presence of the Verification Mission is a key factor in the broad process of building p eace and c onsolidating d emocracy in Guatemala. In due time I intend, therefore, to recommend that the mandate of MINUGUA be extended, as requested by the parties, and that the Mission be provided with the sound financial basis it needs to continue to make its critical contribution to the peace process.

Support by the United Nations system for implementation of the peace accords will be another key contribution to the consolidation of peace and democracy in Guatemala. The comprehensiveness of the accords, combined with the limited availability of external assistance and the expectations of Guatemalan people that peace will soon produce tangible benefits, will call for the redoubling of our efforts, in close collaboration with the Government of Guatemala, to coordinate the United Nations system's response to the demand for verification, good offices and technical assistance to help implement the accords. To ensure an integrated approach, I have called a meeting of relevant United Nations specialized agencies, bodies and programmes, under the chairmanship of the Under-Secretary-General for Political Affairs, to discuss how the United Nations system can best work together in this endeavour.

I would be grateful if you would bring the contents of the present letter to the attention of the members of the General Assembly.

(Signed) Boutros BOUTROS-GHALI

\section{ANNEX}

Agreement on Social and Economic Aspects and Agrarian Situation concluded on 6 May 1996 between the Presidential Peace Commission of the Government of Guatemala and the Unidad Revolucionaria Nacional Guatemalteca Whereas:

A firm and lasting peace must be consolidated on the basis of social and economic development directed towards the common good, meeting the needs of the whole population,

This is necessary in order to overcome the poverty, extreme poverty, discrimination and social and political marginalization which have impeded and distorted the country's social, economic, cultural and political development and have represented a source of conflict and instability, 
Socio-economic development requires social justice, as one of the building blocks of unity and national solidarity, together with sustainable economic growth as a condition for meeting the people's social needs,

Rural areas require an integral strategy that facilitates access by small farmers to land and other production resources, offers juridical security and promotes conflict resolution,

It is essential, both for the realization of the production potential of Guatemalan society and for the achievement of greater social justice, that all sectors of society participate effectively in finding a way to meet their needs, particularly in setting public policies that concern them,

The State should pursue democratization in order to expand those possibilities for participation and strengthen its role as a leader of national development, as a legislator, as a source of public investment and a provider of services and as a promoter of consensus-building and conflict resolution,

This Agreement seeks to create or strengthen mechanisms and conditions to guarantee the effective participation of the people and contains the priority objectives for Government action to lay the foundations of this participatory development,

The implementation of this Agreement should enable all the country's social and political forces to face together, in a cooperative and responsible way, the immediate tasks of combating poverty, discrimination and privilege, thus building a united, prosperous and just Guatemala that will afford a dignified way of life to its people as a whole,

The Government of Guatemala and the Unidad Revolucionaria Nacional Guatemalteca (hereinafter referred to as "the Parties") have agreed as follows:

\section{DEMOCRATIZATION AND PARTICIPATORY DEVELOPMENT}

\section{A. Participation and consensus-building}

1. In order to pursue a true, functional and participatory democracy, the process of social and economic development should be democratic and participatory and include:

(a) consensus-building and dialogue among agents of socio-economic development;

(b) consensus-building between these agents and State bodies in the formulation and implementation of development strategies; and (c) effective citizen participation in identifying, prioritizing and meeting their needs.

2. Expanded social participation is a bulwark against corruption, privilege, distortions of development and the abuse of economic and political power to the detriment of society. Therefore, it is an instrument for the eradication of economic, social and political polarization in society.

3. In addition to representing a factor in democratization, citizen participation in economic and social development is essential in order to promote productivity and economic growth, achieve a more equitable distribution of wealth and train human resources. It ensures transparency in public policies and their orientation towards the 
common good rather than special interests, the effective protection of the interests of the most vulnerable groups, efficiency in providing services and, consequently, the integral development of the individual.

4. In this spirit, and in line with the agreements already concluded on the resettlement of the population groups uprooted by the armed conflict and on identity and rights of indigenous peoples, the Parties agree on the importance of establishing or strengthening mechanisms allowing the citizens and different social groups to exercise their rights effectively and participate fully in decision-making on the various matters affecting or involving them, with full awareness of both their individual and collective obligations to society, which they will fulfil responsibly.

5. Strengthening social participation means that greater opportunities in social and economic decision-making should be offered to organized groups. This assumes that all kinds of grass-roots organizations representing different interests will be recognized and encouraged. It requires, in particular, the guarantee of full and effective rights for rural and urban workers and small farmers to participate, as organized entities, in the process of building consensus with the business sector or at the national level. For this purpose, flexible laws and administrative regulations must be passed to grant legal personality or other forms of legal recognition to those organizations requesting it.

6. This also assumes a major effort to promote a culture of consensus and capacitybuilding in business, labour and other types of organizations in order to increase their ability to plan and negotiate and effectively to assume the rights and duties inherent in democratic participation.

\section{Consensus-building}

7. Building consensus at the national, departmental and communal levels and among rural and urban units of production is essential in order to stimulate and stabilize economic and social growth. State structures must be adapted to fulfil this role of building consensus and reconciling interests, in order to be able to work effectively and efficiently to modernize the production sector, enhance competitiveness, promote economic growth and provide basic social services efficiently and universally.

Participation at the local level

8. Bearing in mind that the people who live in a department or municipality, whether business owners, workers, members of cooperatives or community representatives, are the ones who can best define the measures that benefit or affect them, a package of instruments must be adopted for institutionalizing the decentralization of social and economic decision-making, involving a real transfer of government funds and of the authority to discuss and decide locally on the allocation of resources, how projects will be executed and the priorities and characteristics of government programmes or activities. In this way, government bodies will be able to base their actions on proposals arising from the reconciliation of interests among the various segments of society.

9. Through this Agreement, the Government commits itself to take a series of steps designed to increase the people's participation in the various aspects of public life, including s ocial and r ural d evelopment policies. This s eries of $\mathrm{r}$ eforms must e nable 
structures that generate social conflict to be replaced by new relationships that ensure the consolidation of peace, as an expression of harmonious life together, and the strengthening of democracy, as a dynamic and perfectible process from which advances can be achieved through the participation of various segments of society in shaping the country's political, social and economic choices.

10. In order to reinforce the people's ability to participate and, at the same time, the State's management capacity, the Government agrees to:

\section{Communities}

(a) Promote a reform of the Municipal Code so that deputy mayors are appointed by the municipal mayor, taking into account the recommendations of local residents in an open town council meeting;

\section{Municipalities}

(b) Foster social participation in the context of municipal autonomy, pursuing the process of decentralization to give more authority to municipal governments, and consequently, strengthening their technical, administrative and financial resources;

(c) Establish and implement as soon as possible, in cooperation with the National Association of Municipalities, a municipal training programme that will serve as a framework for national efforts and international cooperation in this field. The programme will stress the training of municipal staff who will specialize in executing the new duties that will be the responsibility of the municipality as a result of decentralization, with an emphasis on land use planning, a land register, urban planning, financial management, project management and training of local organizations so that they can participate effectively in meeting their own needs;

\section{Departments}

(d) Promote in the Congress a reform of the Act concerning the governance of the departments of the Republic, to the effect that the governor of the department would be appointed by the President of the Republic, taking into consideration the candidates nominated by the non-governmental representatives of the departmental development councils;

\section{Regions}

(e) Regionalize health care, education and cultural services for indigenous people and ensure the full participation of indigenous organizations in the design and implementation of this process;

System of urban and rural development councils

(f) Take the following steps, bearing in mind the fundamental role of urban and rural development councils in ensuring, promoting and guaranteeing the people's participation in the identification of local priorities, the definition of public projects and programmes and the integration of national policy into urban and rural development: 
(i) Re-establish local development councils;

(ii) Promote a reform of the Urban and Rural Development Councils Act to broaden the range of sectors participating in departmental and regional development councils;

(iii) Provide adequate funding for the council system.

B. Participation of women in economic and social development

11. The active participation of women is essential for Guatemala's economic and social development, and the State has a duty to promote the elimination of all forms of discrimination against women.

12. R ecognizing w omen's u ndervalued c ontributions in all s pheres of e conomic and social activity, and particularly their efforts towards community improvement, the Parties agree that there is a need to strengthen women's participation in economic and social development on equal terms.

13. To this end, the Government undertakes to take the specific economic and social situation of women into account in its development strategies, plans and programmes, and to train civil servants in analysis and planning based on this approach. This undertaking includes the following:

(a) Recognizing the equal rights of women and men in the home, in the workplace, in the production sector and in social and political life, and ensuring that women have the same opportunities as men, particularly with regard to access to credit, land ownership and other productive and technological resources;

Education and training

(b) Ensuring that w omen h ave e qual o pportunities for e ducation and training in the same conditions as men, and that any form of discrimination against women that may be found in school curricula is eliminated;

Housing

(c) Ensuring that women have equal access to housing of their own by eliminating the obstacles and impediments that affect women in relation to rental property, credit and construction;

Health

(d) Implementing nationwide comprehensive health programmes for women, which involves giving women access to appropriate information, prevention and health care services;

Labour

(e) Guaranteeing women's right to work, which requires: 
(i) Using various means to encourage vocational training for women;

(ii) Revising labour legislation to guarantee equality of rights and opportunities between men and women;

(iii) In rural areas, recognizing women as agricultural workers to ensure that their work is valued and remunerated;

(iv) Enacting laws to protect the rights of women who work as household employees, especially in relation to fair wages, working hours, social security and respect for their dignity;

Organization and participation

(f) Guaranteeing women's right to organize and their participation, on the same terms as men, at the senior decision-making levels of local, regional and national institutions;

(g) Promoting women's participation in public administration, especially in the formulation, execution and supervision of government plans and policies;

Legislation

(h) Revising national legislation and regulations to eliminate all forms of discrimination against women in terms of economic, social, cultural and political participation, and to give effect to the government commitments deriving from the ratification of the Convention on the Elimination of All Forms of Discrimination against Women.

\section{SOCIAL DEVELOPMENT}

14. The State is responsible for promoting, guiding and regulating the country's socioeconomic development so as to ensure economic efficiency, increased social services and social justice in an integrated manner and through the efforts of society as a whole. In the quest for growth, economic policy should be aimed at preventing processes of socio-economic exclusion, such as unemployment and impoverishment, and maximizing the benefits of economic growth for all Guatemalans. In seeking to ensure the well-being of all Guatemalans, social policy should foster economic development through its impact on production and efficiency.

15. Guatemala requires speedy economic growth in order to create jobs and enhance social development. The country's social development, in turn, is essential for its economic growth and for better integration into the world economy. In this regard, better living standards, health, education and training are the pillars of sustainable development in Guatemala.

\section{State responsibilities}

16. The State has inescapable obligations in the task of correcting social inequities and deficiencies, both by steering the course of development and by making public investments and providing universal social services. Likewise, the State has the specific obligations, imposed by constitutional mandate, of ensuring the effective 
enjoyment, without discrimination of any kind, of the right to work, health, education and housing, as well as other social rights. The historical social imbalances experienced in Guatemala must be corrected, and peace must be consolidated, through decisive policies which are implemented by both the State and society as a whole.

Productive investments

17. The country's socio-economic development cannot depend exclusively on public finances or on international cooperation. Rather, it requires an increase in productive investments that create adequately paid jobs. The Parties urge national and foreign entrepreneurs to invest in the country, considering that the signing and implementation of an agreement on a firm and lasting peace are essential components of the stability and transparency required for investment and economic expansion.

Gross domestic product

18. For its part, the Government undertakes to a dopt economic policies designed to achieve steady growth in the gross domestic product of not less than 6 per cent per annum, which would enable it to implement a progressive social policy. At the same time, it undertakes to implement a social policy aimed at ensuring the well-being of all Guatemalans, with emphasis on health, nutrition, education and training, housing, environmental sanitation and access to productive employment and to decent pay.

The State's leadership role

19. To meet this objective and to enable the State to play its leadership role in social policy, the Government undertakes to:

(a) Apply a nd develop the regulatory framework to guarantee the exercise of social rights and provide social services through public entities and, where necessary, through semi-public or private entities, and supervise the adequate provision of such services;

(b) Promote and ensure the participation, in accordance with the regulatory framework, of all social and economic sectors that can cooperate in social development, particularly in providing full access to basic services;

(c) Ensure that the public sector provides services efficiently, considering that the State has a duty to give the population access to quality services.

20. In response to the population's urgent demands, the Government undertakes to:

(a) Increase social investment significantly, especially in the areas of health, education and employment;

(b) Restructure the budget so as to increase social expenditure;

(c) Give priority to the neediest sectors of society and the most disadvantaged areas of the country, without short-changing other sectors of society;

(d) Improve the administration of government resources and investments by decentralizing them and $m$ aking them less concentrated and bureaucratic, $r$ eforming 
budget performance mechanisms by giving them autonomy in decision-making and financial management to guarantee their efficiency and transparency, and strengthening supervisory and auditing mechanisms.

\section{A. Education and training}

21. Education and training have a fundamental role in the country's economic, cultural, social and political development. They are central to the strategy of equity and national unity, and vital for economic modernization and international competitiveness. Reform of the educational system and of its administration is therefore necessary, as is the implementation of coherent and forceful State policies in the field of education, in order to achieve the following objectives:

(a) To affirm and disseminate the moral and cultural values and the concepts and behaviour patterns which are the foundations of democratic coexistence, including respect for human rights, for the cultural diversity of Guatemala, for the productive work of its people and the protection of the environment and for the values and mechanisms of power-sharing and social and political consensus-building which constitute the basis of a culture of peace;

(b) To avoid the perpetuation of poverty and of social, ethnic, sexual and geographical forms of discrimination, particularly those which arise from the divide between urban and rural society;

(c) To contribute to the application of technical and scientific progress and, consequently, to the achievement of higher productivity, the creation of more jobs and increased income for the population, and beneficial integration into the world economy.

22. In response to the country's needs in the field of education, the Government undertakes to:

Spending on education

(a) Implement significant increases in the resources allocated to education. By the year 2000 , the Government proposes to step up public spending on education as a proportion of gross domestic product by at least 50 per cent over its 1995 level. These targets will be revised upwards in the light of future developments in State finances;

Adjustment of educational curricula

(b) Adjust educational curricula in accordance with the objectives set out in paragraph 21. These adjustments will take into account the conclusions of the Education Reform Commission established by the Agreement on Identity and Rights of Indigenous Peoples;

\section{Coverage}

(c) Expand, as a matter of urgency, the coverage of education services at all levels, and in particular the provision of bilingual education in rural communities, by means of: 
(i) The integration of children of school age into the educational system, ensuring that they complete the pre-primary and primary levels and the first level of secondary school; in particular, by the year 2000 , the Government undertakes to provide access, for all those between ages 7 and 12, to at least three years of schooling;

(ii) Literacy programmes in as many languages as is technically feasible, with the participation of suitably qualified indigenous organizations; the Government undertakes to raise the literacy rate to 70 per cent by the year 2000; and

(iii) Education, training and technical courses for adults;

Occupational training

(d) Develop, with appropriate and efficient methodology, training programmes in communities and enterprises for the retraining and technical updating of workers, with emphasis on the inhabitants of isolated areas and rural communities, with support from those sectors which are able to collaborate in this undertaking;

Training for participation

(e) Provide training to enable social organizations at the municipal, regional and national levels to take part in socio-economic development, including the fields of public administration, fiscal responsibility and consensus-building;

Civic education programme

(f) Design and implement a national civic education programme for democracy and peace, promoting the protection of human rights, the renewal of political culture and the peaceful resolution of conflicts. The mass media will be invited to participate in this programme;

Community-school interaction and community participation

(g) In order to encourage the enrolment of children in the educational system and to lower the school drop-out rate, the Government undertakes to encourage effective community and parental participation in the various aspects of the education and training services (curricula, appointment of teachers, school calendar, etc.);

Financial support

(h) Develop scholarship and student grant programmes, economic support and other incentives, to enable needy students to continue their education;

Training of school administrators

(i) Develop continuing education programmes for teachers and school administrators;

Advisory commission

(j) For the purpose of designing and implementing the educational reform to be carried out by the Ministry of Education, an advisory commission attached to the Ministry will 
be set up, consisting of participants in the educational process, including representatives of the Education Reform Commission set up pursuant to the Agreement on Identity and Rights of Indigenous Peoples;

Higher education and research

(k) State-run higher education, the management, organization and development of which is the sole responsibility of the Guatemalan University of San Carlos, is a key factor in achieving economic growth, social equity, the dissemination of culture and a greater pool of technological know-how. The Government of the Republic undertakes to provide to the University of San Carlos, in a timely manner, the funding which is its prerogative under a constitutional mandate. With all due respect to the autonomy of the University, the parties urge the authorities of that distinguished institution to give favourable consideration to all initiatives which increase its contribution to the country's development and help to consolidate peace. The Government undertakes to heed such contributions and initiatives and to respond appropriately. Particular importance is attached to the development of the University's regional centres and of its internship programmes, especially in the poorest sectors. The Parties also urge the business sector to devote increased efforts to applied technological research and to human resources development, forging $\mathrm{c}$ loser exchange links with the University of San Carlos;

\section{Educational outreach workers}

(1) Pursuant to the Agreement on Resettlement of the Population Groups Uprooted by the Armed Conflict and the Agreement on Identity and Rights of Indigenous Peoples, community educational outreach workers shall be incorporated into the national education system, and due regard shall be given to suitable curricula for indigenous communities and uprooted population groups.

\section{B. Health}

23. The Parties agree on the need to promote a reform of the national health sector. This reform should be aimed at ensuring effective exercise of the fundamental right to health, without any discrimination whatsoever, and the effective performance by the State, which w ould b e p rovided with the $n$ ecessary resources, of $i$ ts o bligation $w$ ith regard to health and social welfare. Some of the main points of this reform are as follows:

\section{Concept}

(a) It would be based on an integrated concept of health (including prevention, promotion, recovery and rehabilitation) and on humanitarian and community-based practice emphasizing the spirit of service, and it would be applied at all levels of the country's public health sector;

\section{National coordinated health system}

(b) One of the responsibilities of the Ministry of Health is to formulate policies to provide the entire Guatemalan population with integrated health services. Under the coordination of the Ministry of Health, the health system would combine the work of 
public agencies (including the Guatemalan Social Security Institute) and private and non-governmental organizations involved in this sector to implement actions designed to enable the whole Guatemalan population to have access to integrated health services;

Low-income population

(c) The system would create the conditions for ensuring that the low-income population has effective access to quality health services. The Government undertakes to increase the resources it allocates to health. By the year 2000, the Government proposes to step up public spending on health as a proportion of gross domestic product by at least 50 per cent over its 1995 level. This target will be revised upwards in the light of future developments in State finances;

\section{Priority care}

(d) The system would give priority to efforts to fight malnutrition and to promote environmental sanitation, preventive health care and primary health care, especially maternal and child care. The Government undertakes to allocate at least 50 per cent of public health expenditure to preventive care and undertakes to cut the 1995 infant and maternal mortality rate in half by the year 2000. In addition, the Government undertakes to maintain the certification of eradication of poliomyelitis, and to eradicate measles by the year 2000 ;

Medicine, equipment and inputs

(e) The Ministry of Public Health and Social Welfare will revise current rules and practices with regard to the manufacture and marketing of drugs, equipment and inputs and will promote measures to ensure that these are in sufficient supply and that they are affordable and of high quality. In the case of popular basic or generic drugs, ways of purchasing them will be studied and applied in order to ensure transparency in their marketing, quality and pricing to ensure that services are provided efficiently;

Indigenous and traditional medicine

(f) The system would enhance the importance of indigenous and traditional medicine, promoting its study and renewing its concepts, methods and practices;

Social participation

(g) The system would encourage a ctive participation of municipalities, communities and social organizations (including groups of women, indigenous people, trade unions and civic and humanitarian associations) in the planning, execution and monitoring of the administration of health services and programmes, through local health systems and urban and rural development councils;

Administrative decentralization and enhancement of local autonomy 
(h) The decentralized organization of the various levels of health care should ensure that health programmes and services are offered at the community, regional and national levels, which are the basis of the national coordinated health system.

\section{Social security}

24. Social security is a mechanism for expressing human solidarity and promoting the common good, laying the foundations for s tability, e conomic d evelopment, $\mathrm{n}$ ational unity and peace. Under the Political Constitution of the Republic, the Guatemalan Social Security Institute, an autonomous body, administers the social security system. The Parties consider that appropriate measures should be taken to expand its coverage and increase its benefits and the quality and efficiency of its services. To that end, the following should be taken into account:

(a) The administration of the Guatemalan Social Security Institute should be completely autonomous, in accordance with the constitutional principle of coordination with health agencies under the national coordinated health system;

(b) Under the International Labour Organization convention ratified by Guatemala, social security should include programmes for medical care and benefits in the areas of sickness, maternity, disability, old age, survival, job-related accidents and illnesses, employment and family welfare;

(c) The application of the principles of efficiency, universality, unity and compulsoriness to the operation of the Guatemalan Social Security Institute should be reinforced and guaranteed;

(d) The financial soundness of the Institute should be strengthened through a system of tripartite control of contributions;

(e) New ways of managing the Institute with the participation of its constituent sectors should be promoted;

(f) The Institute should be effectively incorporated into the coordinated health system;

(g) Conditions should be created that will facilitate the universal coverage of all workers by the social security system.

\section{Housing}

25. It has been recognized that there is a need to institute a policy, in accordance with the constitutional mandate, to give priority to the building of low-cost housing, through appropriate financial arrangements, in order to enable as many Guatemalan families as possible to own their own homes. To this end, the Government undertakes to:

\section{Planning}

(a) Closely monitor land management policies, especially urban planning and environmental protection policies, to enable the poor to have access to housing and related services in hygienic and environmentally sustainable conditions; 


\section{Standards}

(b) U pdate health and sa fety r egulations a pplicable to the construction industry and monitor compliance with them; coordinate with municipalities to ensure that construction and supervision standards are homogeneous, clear and simple, in an effort to provide high-quality, safe housing;

Housing stock

(c) P romote a policy to increase the stock of housing in Guatemala, in an effort to enable more people from low-income sectors to rent or own their own homes;

(d) Increase the supply of housing-related services, housing options and high-quality, low-cost building materials; in this context, apply anti-trust regulations to the production and marketing of building materials and housing-related services in accordance with article 130 of the Constitution;

Finance and credit

(e) Implement monetary policies designed to reduce the cost of credit significantly;

(f) Strengthen the securities market and make it more available as a source of funds to purchase housing, by offering first and second mortgages and facilitating the selling of securities issued for housing operations, such as common and preferred stocks in construction companies, mortgage bonds and debentures, real estate participation certificates, supplemental letters, promissory notes and other documents related to rental with an option to buy;

(g) Design a direct subsidy mechanism and apply it to the demand for low-cost housing, to benefit the most needy sectors. To this end, strengthen the Guatemalan Housing Fund to improve its capacity to grant funds to assist those living in poverty and extreme poverty;

Participation

(h) Stimulate the establishment and strengthening of participatory arrangements, such as cooperatives and self-managed and family businesses, to ensure that the beneficiaries are able to participate in the planning and construction of housing and related services;

Regularization of the land situation

(i) Promote the legalization, access to and registry of land, not only in the vicinity of Guatemala City but also for urban development in the province capitals and municipalities, together with the implementation of building projects in villages and on farms, especially rural housing;

National commitment

(j) In view of the size and urgency of the housing problem, national efforts should be mobilized to solve it. The Government undertakes to allocate to the housing promotion 
policy no less than 1.5 per cent of the tax revenue budget, beginning in 1997, giving priority to the subsidy for low-cost housing options.

\section{E. Work}

26. Work is essential for the integral development of the individual, the well-being of the family and the social and economic development of Guatemala. Labour relations are an essential element of social participation in socio-economic development and of economic efficiency. In this respect, the State's policy with regard to work is critical for a strategy of growth with social justice. In order to carry out this policy, the Government undertakes to:

Economic policy

(a) Through an economic policy designed to increase the use of the labour force, create conditions for the attainment of rising and sustained levels of employment, while sharply reducing structural underemployment and making possible a progressive increase in real wages;

(b) Encourage measures in coordination with the various social sectors to increase investment and productivity within the framework of an overall strategy of growth with social stability and equity;

Protective labour legislation

(c) Promote, in the course of 1996, legal and regulatory changes to enforce the labour laws and severely penalize violations, including violations in respect of the minimum wage, non-payment, withholding and delays in wages, occupational hygiene and safety and the work environment;

(d) Decentralize and expand labour inspection services, strengthening the capacity to monitor compliance with the labour norms of domestic law and those derived from the international labour agreements ratified by Guatemala, paying particular attention to monitoring compliance with the labour rights of women, migrant and temporary agricultural w orkers, h ousehold w orkers, $m$ inors, the e lderly, the disabled and o ther workers who are in a more vulnerable and unprotected situation;

Occupational training

(e) Establish a permanent, modern vocational instruction and training programme to ensure training at all levels and a corresponding increase in productivity through a draft law regulating vocational training at the national level;

(f) Promote coverage by the national vocational instruction and training programmes of at least 200,000 workers by the year 2000 , with an emphasis on those who are joining the workforce and those who need special training to adapt to new conditions in the labour market;

Ministry of Labour 
(g) Strengthen and modernize the Ministry of Labour and Social Welfare, ensuring its leading role in Government policies related to the labour sector and its effective deployment in the promotion of employment and in labour cooperation. To that end, it undertakes to:

Participation, coordination and negotiations

(i) Promote the restructuring of labour relations in enterprises by encouraging labour management cooperation and coordination with a view to the development of the enterprise for the common good, including possible profit-sharing arrangements;

(ii) Facilitate the procedures for the recognition of the legal personality of labour organizations;

(iii) In the case of agricultural workers who are still hired through contractors, propose reforms for the speedy and flexible legal recognition of forms of association for the negotiation of such hiring; and

(iv) Promote a culture of negotiation and, in particular, train persons to settle disputes and coordinate action for the benefit of the parties involved.

\section{AGRARIAN SITUATION AND RURAL DEVELOPMENT}

27. It is essential and unavoidable to solve the problems of agrarian reform and rural development in order to address the situation of the majority population, which live in rural areas and is most affected by poverty, extreme poverty, injustice and the weakness of State institutions. The transformation of the structure of land use and ownership must have as its objective the incorporation of the rural population into economic, social and political development so that the land constitutes, for those who work it, the basis of their economic stability, the foundation of their progressive social well-being and the guarantee of their freedom and dignity.

28. L and is central to the problems of rural development. From the conquest to the present, historic events, often tragic, have left deep traces in ethnic, social and economic relations concerning property and land use. These have led to a situation of concentration of resources which contrasts with the poverty of the majority and hinders the development of Guatemala as a whole. It is essential to redress and overcome this legacy and promote more efficient and more equitable farming, strengthening the potential of a ll those involved, $n$ ot only in terms of $p$ roductive $c$ apacity $b$ ut a lso in enhancing the cultures and value systems which coexist and intermingle in the rural areas of Guatemala.

29. These changes will enable Guatemala to take full advantage of the capacities of its inhabitants and, in particular, the richness of the traditions and cultures of its indigenous peoples. It should also take advantage of the high potential for agricultural, industrial, commercial and tourist development of those resources deriving from its wealth of natural resources.

30. Solving the agrarian problem is a complex process covering many aspects of rural life, from modernization of production and cultivation methods to environmental protection, as well as security of property, adequate use of the land and of the labour 
force, labour protection and a more equitable distribution of resources and the benefits of development. This is also a social process whose success depends not only on the State, but also on a combination of efforts on the part of the organized sectors of society, in the awareness that the common good requires breaking with the patterns and prejudices of the past and seeking new and democratic forms of coexistence.

31. The State has a fundamental and vital role in this process. As the guide for national development, as a legislator, as a source of public investment and provider of services and as a promoter of social cooperation and conflict resolution, it is essential for the State to increase and refocus its efforts and its resources towards the rural areas, and to promote agrarian modernization, in a sustained manner, in the direction of greater justice and greater efficiency.

32. The agreements already signed on human rights, on the resettlement of populations uprooted by armed confrontation and on the identity and rights of indigenous peoples contain commitments which constitute essential elements of a global strategy for rural development. It is in line with these provisions that the Government undertakes, through this Agreement, to promote an integral strategy covering the multiple elements which make up agrarian structure, including land ownership and the use of natural resources; credit systems and mechanisms; manufacturing and marketing; agrarian legislation and l egal se curity; 1 abour r elations; t echnical assistance and training; the sustainability of natural resources and the organization of the rural population. This strategy includes the aspects described below.

\section{A. Participation}

33. The capacity of all actors involved in the agricultural sector must be mobilized to make proposals and to take action, including indigenous peoples' organizations, producers' associations, business associations, rural workers' trade unions, rural and women's organizations or universities and research centres in Guatemala. To that end, in addition to the provisions of other chapters of this Agreement, the Government undertakes to:

(a) Strengthen the capacity of rural organizations such as associative rural enterprises, cooperatives, small farmers' associations, mixed enterprises and self-managed and family businesses to participate fully in decisions on all matters concerning them and to establish or strengthen State institutions, especially those of the State agricultural sector, involved in rural development so that they can promote such participation, particularly the full participation of women in the decision-making process. That will strengthen the effectiveness of State action and ensure that it responds to the needs of rural areas. In particular, participation in development councils will be promoted as a framework for the joint formulation of development and land use plans;

(b) Strengthen and expand the participation of tenant farmers' organizations, rural women, indigenous organizations, cooperatives, producers' trade unions and nongovernmental organizations in the National Agricultural Development Council as the main mechanism for consultation, coordination and social participation in the decisionmaking process for rural development, and in particular for the implementation of this chapter.

B. Access to land and productive resources 
34. Promote the access of tenant farmers to land ownership and the sustainable use of land resources. To that end, the Government will take the following actions:

Access to land ownership: land trust fund

(a) Establish a land trust fund within a broad-based banking institution to provide credit and to promote savings, preferably among micro-, small and medium-sized enterprises. The land trust fund will have prime responsibility for the acquisition of land through Government funding, will promote the establishment of a transparent land market and will facilitate the updating of land development plans. The fund will give priority to the allocation of land to rural men and women who are organized for that purpose, taking into account economic and environmental sustainability requirements;

(b) In order to ensure that the neediest sectors benefit from its services, the fund will set up a special advisory and management unit to serve rural communities and organizations;

(c) Initially, the fund will limit its activities to the following types of land:

(i) Uncultivated State land and State-owned farms;

(ii) Illegally settled public land, especially in Petén and the Franja Transversal del Norte, which the Government has pledged to recover through legal action;

(iii) Land acquired with the resources allocated by the Government to the National Land Fund and the National Peace Fund for that purpose;

(iv) Land purchased with grants from friendly Governments and international nongovernmental organizations;

(v) Land purchased with loans secured from international financing agencies;

(vi) Undeveloped land expropriated under article 40 of the Constitution;

(vii) Land acquired from the proceeds of the sale of excess land, as determined by comparing the actual dimensions of private property with the dimensions recorded at the land register department, which has become the property of the State;

(viii) Land which the State may purchase pursuant to Decree No. 1551, article 40, on agricultural development areas;

(ix) Land which the State may purchase for any purpose; and

(x) Miscellaneous grants;

(d) The Government will promote and enact legislation to regulate all the activities of the land trust fund. Such legislation will establish, inter alia, the fund's aims, functions and financing and acquisition mechanisms, and the allocation, origin and destination of 
land. In 1999, the extent to which the allocation targets have been met will be assessed and, if need be, the functioning of the land allocation programme will be adjusted;

Access to land ownership: funding mechanisms

(e) Promote, through all means possible, the development of a dynamic land market that would enable tenant farmers who either do not have land or have insufficient land to acquire land through long-term transactions at commercial or favourable interest rates with little or no down payment. In particular, promote the issuance of mortgagebacked securities guaranteed by the State whose yield is attractive to private investors, especially financial institutions;

Access to the use of natural resources

(f) By 1999, allocate to small and medium-sized farmers' groups legally incorporated as natural resources management ventures, 100,000 hectares within multi-use areas for sustainable forest management, the management of protected areas, eco-tourism, conservation of water sources and other activities compatible with the sustainable potential use of the natural resources of such areas;

(g) Promote and support the participation of the private sector and grass-roots community organizations in projects for the management and conservation of renewable natural resources through incentives, targeted direct subsidies or funding mechanisms on soft terms, in view of the non-monetary benefits that the national community derives from such projects. Given the benefit that the international community receives from the sustainable management and conservation of the country's forest and biogenetic resources, the Government will actively promote international cooperation in this venture;

Access to other productive projects

(h) Develop sustainable productive projects especially geared towards boosting productivity and the processing of agricultural, forestry and fishery products in the poorest areas of the country. In particular, for the period 1997-2000, guarantee the implementation, in the poorest areas, of a Government agricultural sector investment programme in the amount of 200 million quetzales in the agriculture, forestry and fisheries sectors;

(i) Promote a renewable natural resources management programme which fosters sustainable forestry and agro-forestry production, as well as handicrafts and small- and medium-scale industry projects that give added value to forest products;

(j) Promote productive ventures related, inter alia, to agro-processing industries, marketing, services, handicrafts and tourism with a view to creating jobs and securing fair incomes for all;

(k) Promote an eco-tourism programme with the broad participation of communities which have received appropriate training.

C. Support structure 
35. Prerequisites for a more efficient and just agricultural structure include not only more equitable access to productive resources but also a support structure that will enhance farmers' access to information, technology, training, credit and marketing facilities. Over and above its commitment to social investment as set forth in the chapter on social development, including in particular investment in health, education, housing and employment, the Government also undertakes to:

\section{Basic infrastructure}

(a) Engage in judicious public investment and foster a climate c onducive to $p$ rivate investment with a view to upgrading the infrastructure available for sustainable production and marketing, especially in areas of poverty and extreme poverty;

(b) Develop a rural development investment programme with emphasis on basic infrastructure (highways, rural roads, electricity, telecommunications, water and environmental sanitation) and productive projects, for a total amount of 300 million quetzales annually during the period 1997-1999;

\section{Credit and financial services}

(c) Activate the land fund not later than 1997, while simultaneously promoting conditions that will enable small and medium-scale farmers to have access to credit, individually or in groups, on a financially sustainable basis. In particular, with the support of the private sector and non-governmental development organizations, the Government proposes to strengthen local savings and credit agencies, including associations, cooperatives and the like, with a view to enhancing their function as sources of credit providing small and medium-scale farmers with financial services efficiently and in accordance with local needs and conditions;

\section{Training and technical assistance}

(d) Strengthen, decentralize and broaden the coverage of training programmes, especially programmes designed to enhance rural people's managerial skills at various levels. The private sector and non-governmental organizations will be enlisted in the implementation of this action;

(e) Develop technical assistance and job training programmes that will upgrade the skills, versatility and productivity of the labour force in rural areas;

\section{Information}

(f) Develop an information collection, compilation and distribution system for the agriculture, forestry, food processing and fisheries sectors, one that will provide small producers with reliable information on which to base their decisions relating to seeds, inputs, crops, costs and marketing;

\section{Marketing}

(g) Develop a system of storage centres and duty-free zones with a view to facilitating the processing and marketing of agricultural products and fostering rural employment. 


\section{Organization of the rural population for production}

36. Organizing the rural population is a decisive factor in transforming the inhabitants of the countryside into genuine protagonists of their own development. In view of the vital role of small and medium-scale enterprises in combating poverty, creating rural jobs and promoting more efficient land use, there is a need to promote a more efficient form of organization of small producers so that they can, in particular, take advantage of the support structure described in paragraph 35. To this end, the Government undertakes to:

(a) Support micro-, small and medium-scale agricultural and rural enterprises by strengthening the various ways of organizing them, such as associative rural enterprises, cooperatives, small farmers' associations, mixed enterprises and selfmanaged and family businesses;

(b) Tackle the problem of smallholdings through:

(i) A firm and sustained policy of support for smallholders so that they can become small-scale agricultural businessmen through access to training, technology, credit and other inputs;

(ii) Promoting, if the smallholders so desire, amalgamation of holdings in those cases where conversion into small businesses is not possible owing to the dispersal and size of the properties.

\section{E. Legal framework and juridical security}

37. Guatemala is in need of reform of the juridical framework of agriculture and institutional development in the rural sector so that an end can be put to the lack of protection and dispossession from which small farmers, and in particular indigenous peoples, have suffered, so as to permit full integration of the rural population into the national economy and regulate land use in an efficient and environmentally sustainable manner in accordance with development needs. To this end, and taking into account in all cases the provisions of the Agreement on Identity and Rights of Indigenous Peoples, the Government undertakes to:

\section{Legal reform}

(a) Promote a legal reform which will establish a juridical framework governing land ownership that is secure, simple and accessible to the entire population. This reform will need to simplify the procedures for awarding title and registering ownership and other real estate rights, as well as to simplify administrative and judicial formalities and procedures;

(b) Promote the establishment of an agrarian and environmental jurisdiction within the judiciary through the enactment of the relevant legislation by the Congress;

(c) Promote the revision and adjustment of the legislation on undeveloped land so that it conforms to the provisions of the Constitution, and regulate, inter alia through incentives and penalties, the underutilization of land and its use in ways incompatible with sustainable natural resource utilization and preservation of the environment; 
(d) Protect common and municipal land, in particular by limiting to the strict minimum the cases in which it can be transferred or handed over in whatever form to private individuals;

(e) With respect to community-owned land, to regulate participation by communities in order to ensure that it is they who take the decisions relating to their land;

Prompt settlement of land conflicts

(f) To establish and apply flexible judicial or non-judicial procedures for the settlement of disputes relating to land and other natural resources (in particular, direct settlement and conciliation), taking into account the provisions of the Agreement on Resettlement of the Population Groups Uprooted by the Armed Conflict and the Agreement on Identity and Rights of Indigenous People. In addition, to establish procedures that will make it possible:

(i) To define formulas for compensation in the case of land disputes and claims in which farmers, small farmers and communities in a situation of extreme poverty have been or may be dispossessed for reasons not attributable to them;

(ii) To reinstate or compensate, as appropriate, the State, municipalities, communities or individuals when their land has been usurped or has been allocated in an irregular or unjustified manner involving abuse of authority;

(g) Regulate the award of title to the lands of indigenous communities and beneficiaries of the Guatemalan Institute for Agrarian Reform who are in lawful possession of the land assigned to them;

Institutional mechanisms

(h) By 1997, to have started the operations of a Presidential office for legal assistance and conflict resolution in relation to land, with nationwide coverage and the task of providing advice and legal assistance to small farmers and agricultural workers with a view to the full exercise of their rights, and in particular of:

(i) Advising and providing legal assistance to small farmers and agricultural workers and/or their organizations upon request;

(ii) Intervening in land disputes at the request of a party with a view to arriving at a just and expeditious solution;

(iii) In the case of judicial disputes, providing advice and legal assistance free of charge to small farmers and/or their organizations when they so request;

(iv) Receiving complaints of abuses committed against communities, rural organizations and individual small farmers and bringing them to the attention of the Office of the Counsel for Human Rights and/or of any other national or international verification mechanism.

G. Land register 
38. On the basis of the provisions of paragraph 37, the Government undertakes to promote legislative changes that would make it possible to establish an efficient decentralized multi-user land registry system that is financially sustainable, subject to compulsory updating and easy to update. Likewise, the Government undertakes to initiate, by January 1997 at the latest, the process of land surveying and systematizing the land register information, starting with priority zones, in particular with a view to the implementation of paragraph 34 on access to land and other production resources.

\section{H. Labour protection}

39. The Government undertakes to promote better participation of rural workers in the benefits of agriculture and a reorientation of labour relations in rural areas. It will place particular emphasis on applying to rural workers the labour policy outlined in the relevant section of the present agreement. An energetic labour protection policy, combined with a vocational training policy, is in line with the requirements of social justice. It is also needed in order to attack rural poverty and promote an agrarian reform aimed at more efficient use of natural and human resources. Accordingly, the Government undertakes to:

(a) Ensure that the labour legislation is effectively applied in rural areas;

(b) Pay urgent attention to the abuses to which rural migrant workers, y oung tenant farmers and day labourers are subjected in the context of hiring through middlemen, sharecropping, payment in kind and the use of weights and measures. The Government undertakes to adopt administrative and/or penal sanctions against offenders;

(c) Promote reform of the procedures for recognition of the legal personality of small farmers' organizations with a view to simplifying such recognition and making it more flexible through the application of the 1975 International Labour Organization Convention 141 on organization of rural workers.

\section{Environmental protection}

40. Guatemala's natural wealth is a valuable asset of the country and mankind, in addition to being an essential part of the cultural and spiritual heritage of the indigenous peoples. The irrational exploitation of Guatemala's biogenetic and forest resource diversity endangers a human environment that facilitates sustainable development. Sustainable development is understood as being a process of change in the life of the human being through economic growth with social equity, involving production methods and consumption patterns that maintain the ecological balance. This process implies respecting ethnic and cultural diversity and guaranteeing the quality of life of future generations.

41. In this sense, and in line with the principles of the Central American Alliance for Sustainable Development, the Government reiterates the following commitments:

(a) To adjust educational curricula and training and technical assistance programmes to the requirements of environmental sustainability;

(b) To give priority to environmental sanitation in its health policy; 
(c) To link physical planning policies, particularly urban planning, with environmental protection;

(d) To promote sustainable natural resource management programmes that will create jobs.

\section{J. Resources}

42. In order to finance the measures mentioned above, and in view of the priority assigned to modernizing the agriculture sector and rural development, the Government undertakes to increase the State resources allocated to this area by, inter alia:

\section{Land tax}

(a) Promoting, by 1997, the legislation and mechanisms for the application, in consultation with municipalities, of a land tax in the rural areas from which it is easy for the municipalities to collect revenues. The tax, from which small properties will be exempt, will help to discourage ownership of undeveloped land and underutilization of land. Taken as a whole, these mechanisms ought not to encourage deforestation of land use for forestry;

Tax on undeveloped land

(b) Establishing a new tax schedule for the annual tax on undeveloped land which imposes significantly higher taxes on privately owned unutilized and/or underutilized land.

\section{MODERNIZATION OF GOVERNMENT SERVICES AND FISCAL POLICY}

\section{A. Modernization of government services}

43. Government services should become an efficient tool of development policies. To this end, the Government undertakes to:

\section{Decentralization and redistribution}

(a) Deepen the decentralization and redistribution of the powers, responsibilities and resources concentrated in the central Government in order to modernize, render effective and streamline government services. Decentralization should ensure the transfer of $d$ ecision-making p ower and sufficient $r$ esources to the a ppropriate levels (local, municipal, departmental and regional) so as to meet the needs of socioeconomic development in an efficient way and promote close cooperation between government bodies and the population. This implies:

(i) Promoting an amendment to the Executive Authority Act and the Departmental Control and Administration Act and, in particular, to Decree No. 586 of 1956, which will make it possible to simplify, decentralize and redistribute government services; 
(ii) Promoting the decentralization of support systems, including the purchasing and procurement system, the human resources system, the information-gathering and statistical system and the financial management system.

National auditing

(b) Reform, strengthen and modernize the Comptroller's Office.

Professionalization and advancement of public servants

44. The State should have a skilled labour force which can ensure the honest and efficient management of public funds. To this end, it is necessary to:

(a) Establish a career civil service;

(b) Adopt legal and administrative measures to ensure real compliance with the Integrity and Accountability Act;

(c) Promote criminal sanctions for acts of corruption and misappropriation of public funds.

B. Fiscal policy

45. Fiscal policy (revenue and expenditure) is the key tool enabling the State to comply with its constitutional commitments, particularly those relating to social development, which is essential to the quest for the common good. Fiscal policy is also essential to Guatemalan sustainable development, which has been impaired by low levels of education, h ealth $\mathrm{c}$ are and $\mathrm{p}$ ublic s ecurity, a lack of i nfrastructure and other factors which militate against increasing the productivity of labour and the competitiveness of the Guatemalan economy.

Budgetary policy

46. Budgetary policy should respond to the need for socio-economic development in a stable context, which requires a public spending policy consistent with the following basic principles:

(a) Giving priority to social spending, the provision of public services and the basic infrastructure needed to support production and marketing;

(b) Giving priority to social investment in health care, e ducation and housing; rural development; job creation; and compliance with the commitments entered into under the peace agreements. The budget should include sufficient resources for strengthening the organizations and institutions responsible for ensuring the rule of law and respect for human rights;

(c) Efficient budget performance, with an emphasis on decentralization, redistribution and auditing of budgetary resources.

Tax policy 
47. Tax policy should be designed to enable the collection of the resources needed for the performance of the State's functions, including the funds required for the consolidation of peace, within the framework of a tax system consistent with the following basic principles:

(a) The system is fair, equitable and, on the whole, progressive, in keeping with the constitutional principle of ability to pay;

(b) The system is universal and compulsory;

(c) The system stimulates saving and investment.

48. The State should also ensure efficiency and transparency in tax collection and fiscal management so as to promote taxpayer confidence in government policy and eliminate tax evasion and fraud.

Tax collection target

49. Bearing in mind the need to increase State revenues in order to cope with the urgent tasks of economic growth, social development and building peace, the Government undertakes to ensure that by the year 2000, the tax burden, measured as a ratio of gross domestic product, increases by at least 50 per cent as compared with the 1995 tax burden.

\section{Fiscal commitment}

50. As a step towards a fair and equitable tax system, the Government undertakes to address the most serious issue relating to tax injustice and inequity, namely, evasion and fraud, especially on the part of those who should be the largest contributors. In order to eradicate privileges and abuses, eliminate tax evasion and fraud and implement a tax system which is, on the whole, progressive, the Government undertakes to:

Legislation

(a) Promote an amendment to the Tax Code establishing harsher penalties for tax evasion, avoidance and fraud, both for taxpayers and for tax administration officials;

(b) Promote an amendment to the tax laws designed to eliminate loopholes;

(c) Evaluate and regulate tax exemptions strictly so as to eliminate abuses;

Strengthening of tax administration

(d) Strengthen the existing auditing and collection mechanisms, such as crosschecking, tax identification numbers and tax credits for withholding of income tax and value-added tax;

(e) Simplify and automate tax administration procedures; 
(f) Ensure the correct and prompt application or reimbursement of tax credit and punish severely those who do not return withheld value-added tax to the tax authorities;

(g) Create a special programme for large contributors in order to ensure that they comply fully with their tax obligations;

(h) Implement administrative structures specifically g eared to the revenue collection and auditing programmes and to the application of the relevant tax laws;

(i) Strengthen the capacity of municipalities to exercise their authority to collect taxes;

Participation

(j) Ensure that the urban and rural development councils contribute to the definition and monitoring of tax policy within the framework of their mandate to formulate development policies;

Civic education

(k) Within academic curricula, continue to promote knowledge of, respect for and compliance with tax obligations as part of coexistence in a democratic society.

Enforcement of tax policy

51. The failure to fulfil tax obligations deprives the country of the resources needed in order to address the backlog of social needs affecting Guatemalan society. The Government undertakes to impose exemplary penalties on those who engage in various types of tax fraud, to modernize and strengthen tax administration and to give priority to spending on social needs.

\section{FINAL PROVISIONS}

1. This Agreement shall form part of the agreement on a firm and lasting peace and shall enter into force at the time of the signing of the latter agreement.

2. In order to ensure that this Agreement serves the interests of Guatemalans, the Government shall initiate immediately the programming and planning activities which will enable it to comply with the investment commitments contained herein.

3. In accordance with the Framework Agreement, the Secretary-General of the United Nations is requested to verify compliance with this Agreement.

4. This Agreement shall be disseminated as widely as possible; to this end, the cooperation of the mass media and of teaching and educational institutions is requested.

Mexico City, 6 May 1996 
For the Government of the Republic of Guatemala

Gustavo PORRAS CASTEJÓN

Raquel ZELAYA ROSALES

Brigadier General Otto PÉREZ MOLINA

Richard AITKENHEAD CASTILLO

For the Unidad Revolucionaria Nacional Guatemalteca

General Command

Commander Pablo MONSANTO

Commander Rolando MORÁN

Commander Gaspar ILOM

Carlos GONZALES

For the United Nations

Marrack GOULDING

Under-Secretary-General

Jean ARNAULT 


\section{Bibliography}

\section{Official Documents}

Acuerdo de El Escorial [cited 3 May 2001]. Available from http://minugua.guate.net.

Acuerdo de Oslo [cited 5 June 2001]. Available from

http://www.minugua.guate.net/negociacion/73a76.htm.

Agreement on Constitutional Reforms and the Electoral Regime 7 December 1996

[cited 3 May 2001]. Available from http://www.minugua.guate.net/.

Agreement on Resettlement of the Population Groups Uprooted by the Armed Conflict 17 June 1994 [cited 3 May 2001]. Available from http://www.minugua.guate.net/.

Agreement on the Identity and Rights of Indigenous Peoples 31 March 1995 [cited 3

May 2001]. Available from [http://www.un.org.Depts/minugua].

Agreement on the Social and Economic Aspects and Agrarian Situation 6 May 1996

[cited 3 May 2001]. Available from [http://www.un.org.Depts/minugua].

Agreement on the Strengthening of Civilian Power and the Role of the Armed Forces in a Democratic Society 19 September 1996 [cited 3 May 2001]. Available from [http://www.un.org.Depts/minugua].

The Comprehensive Agreement on Human Rights 29 March 1994 [cited 3 May 2001]. Available from http://www.minugua.guate.net/.

Comunicado del CACIF en Ottawa [cited 3 May 2001]. Available from $\mathrm{http}: / / \mathrm{www} \cdot \mathrm{minugua}$.guate.net/negociacion/83a84.htm.

Declaración de Atlixco [cited 31 May 2001]. Available from $\mathrm{http}: / / \mathrm{www} . \mathrm{minugua} . g u a t e . n e t /$ negociacion/95a100.htm.

Declaración de Metepec [cited 31May 2001]. Available from http://www.minugua.guate.net/negociacion/89a94.htm.

Declaración de Quito [cited 31 May 2001]. Available from http://www.minugua.guate.net/negociacion/85a88.htm.

Statement of the Delegation of Guatemala in the Security Council on Disarmament, Demobilization and Reintigration March 232000 [cited 3 May 2001]. Available from www.un.int/guatemala/english/speeches/pysd/2000/english.html.

\section{Interviews}

Arnault, Jean. Oxford, 16 November 2001.

Asturias, Rodrigo. Guatemala, 6 April 2001.

Briz, Jorge. Guatemala, April 2001. 
Castillo, Rolando. Guatemala, 16 April 2001.

Corlazzoli, Juan Pablo. Guatemala, 18 April 2001.

Coxil, Enrique. Guatemala, 2 April 2001.

Fuentes, Juan Alberto. Guatemala, 4 April 2001.

Gonzalez, Eduardo. Guatemala, 24 April 2001.

Macahio, T. Guatemala, 23 April 2001.

Noriega, Arnoldo. Guatemala, 25 April 2001.

Pivaral, José. Guatemala, 3 April 2001.

Porras, Gustavo. Guatemala, 24 April 2001.

Raymundo, Francisco. Guatemala, 2 April 2001.

Rodriguez, Gustavo. Guatemala, 4 April 2001.

Rosende, Raúl. Guatemala, 17 April 2001.

Stein, Ricardo. Guatemala, 24 April 2001.

Tiney, Juan. Guatemala, 5 April 2001.

Tiu, Romeo. Guatemala, 19 April 2001.

Wohlers, Patricia. Guatemala, 17 April 2001.

Zelaya, Raquel. Guatemala, 3 April 2001.

\section{Articles, Books and Other Sources}

Adams, Richard. Crucifixion by Power: Essays on Guatemalan National Social Structure, 1944-1966. Austin: University of Texas Press, 1970.

Adams, Richard N. 'Conclusions: What Can We Know About the Harvest of Violence?' In Harvest of Violence: The Maya Indians and the Guatemalan Crisis, edited by Robert M. Carmack, 274-92. Norman: University of Oklahoma Press, 1988.

- 'Strategies of Ethnic Survival in Central America'. In Nations-States and Indians in Latin America, edited by Greg Urban and Joel Sherzer, 181-206. Austin: Univeristy of Texas Press, 1991.

Adamson, Walter L. Hegemony and Revolution: A Study of Antonio Gramsci's Political and Cultural Theory. Berkeley: University of California Press, 1980.

Adler, John H. Public Finance and Economic Development in Guatemala. Westport, CT: Greenwood Press, 1970.

Aguilar Zinser, Adolofo. 'Negotiation in Conflict: Central America and Contadora'. In Crisis in Central America: Regional Dynamics and US Policy in the 1980s, 
edited by Nora Hamilton, Jeffery A. Frieden, Linda Fuller and Jr. Manuel Pastor, 97-119. Boulder: Westview Press, 1988.

Aguilera, Gabriel. 'Los Temas Substantivos en las Propuestas para la Paz'. In Debate. Guatemala: FLACSO, 1994.

Aguilera, Gabriel, Rosalinda Bran, and Claudinne Ogaldes. Buscando la Paz: El Bienio 1994-1995. Vol. 32, Debate. Guatemala: FLACSO, 1996.

Aguilera Perlata, Gabriel. 'Llegar a la Paz: La Experiencia de Guatemala'. América Indígena 57, no. 1-2 (1997): 89-104.

Ahluwalia, Pal. 'Specificities: Citizens and Subjects: Citizenship, Subjectivity and the Crisis of Modernity'. Social Identities 5, no. 3 (1999): 313-29.

Ahmad, Aijaz. 'Post Colonial Theory and the 'Post-' Condition'. In Socialist Register 1997: Ruthless Criticism of all that Exists, edited by Leo Panitch. Black Point, Nova Scotia: Fernwood, 1997.

Althusser, Louis. Lenin and Philosophy, and Other Essays. New York: Monthly Review Press, 1971.

Althusser, Louis, and Etienne Balibar. Reating Capital. London: Verso, 1979.

Altvater, Elmar. 'The Growth Obsession'. In Socialist Register 2002: A World of Contradictions, edited by Leo Panitch and Colin Leys. Black Point, Nova Scotia: Fernwood, 2002.

Altvater, Elmar, and Birgit Mahnkopf. 'The World Market Unbound'. Review of International Political Economy 4, no. 3 (1997): 448-71.

Amin, Samir. Imperialism and Unequal Development. New York: Monthly Review Press, 1977.

. Unequal Development. New York: Monthly Review Press, 1976.

Amnesty International. 'Guatemala: State of Impunity'. 56. London: Amnesty International, 1997.

Amoore, Louise, Richard Dodgson, Randall D. Germain, Barry K. Gills, Paul Langley, and I ain Watson. 'Paths to a Historicized International Economy'. Review of International Political Economy 7, no. 1 (2000): 53-71.

Andersen, Robert B. 'Unilateralism and Multilateralism in a Transitional World: Lessons of the Arias Peace Plan'. Peace and Change 17, no. 4 (1992): 434-57.

Anderson, Benedict. Imagined Communities. Revised ed. London: Verso, 1991.

Anderson, Mary B. Do No Harm: How Aid Can Support Peace-or War. Boulder: Lynne Rienner, 1999.

Anderson, Perry. 'The Antinomies of Antonio Gramsci'. New Left Review, no. 100 (1976-7): 5-78. 
Anderton, Charles H., and Anderton Roxanne A. 'The Economics of Conflict, Production and Exchange'. In Economics of Conflict and Peace, edited by Jurgen Brauer and William G. Gissy, 54-73. Aldershot: Avebury, 1997.

Annis, Sheldon. God a nd Production in a Guatemalan Town. A ustin: University of Texas Press, 1987.

Arias, Arturo. 'Changing Indian Identity: Guatemala's Violent Transition to Modernity'. In Guatemalan Indians and the State, 1540 to 1988, edited by Carol Smith, 230-58. Austin: University of Texas Press, 1990.

- ed. The Rigoberta Menchú Controversy. Minneapolis: University of Minnesota Press, 2001.

'Arias's Central American peace plan gains European support'. Latin America Weekly Report, 28 May 1987, 1.

Armbruster-Sandoval, Ralph. 'Globalization and Cross-Border Labor Organizing: The Guatemalan Maquiladora Industry and the Phillips Van Heusen Workers' Movement'. Latin American Perspectives 26, no. 2 (1999): 108-28.

Armira, Wenceslao. 'Los Acuerdos sobre Identidad y Derechos de los Pueblos Indígenas y el Trabajo de la Coordinatdora de Organizaciones del Pueblo Maya de Guatemala (COPMAGUA - SAQB ICHIL)'. América Indígena 57, no. 1-2 (1997): 63-71.

Armon, Jeremy, Rachel Sieder, and Richard Wilson, eds. Negotiating Rights: The Guatemalan Peace Process. 2 ed. London: Conciliation Resources, 1997.

Arnson, Cynthia, ed. Comparative Peace Processes in Latin America. Stanford: Stanford University Press, 1999.

Arrighi, Giovanni. 'The Three Hegemonies of Historical Capitalism'. In Gramsci, Historical Materialism and International Relations, edited by Stephen Gill, 148-85. Cambridge: Cambridge University Press, 1993.

Arzú Irigoyen, Alvaro. 'Address by HE Alvaro Arzú Irigoyen at the General Debate of the Fifty-Second Session of the United Nations General Assembly'. New York, 1997.

Arzú, Marta Elena Casaús. 'Reflexiones en Torno a la Legitimidad del Estado, la Nación y la Identidad en el Marco de los Acuerdos de Paz en Guatemala'. In Guatemalan After the Peace Accords, edited by Rachel Sieder, 116-39. London: University of London Institute of Latin American Studies, 1998.

Asemblea de la Sociedad Civil. Propuesta de la Asamblea de la Sociedad Civil - El Ejercito en Democracia [cited 10 June 2002]. Available from http://www.us.net/cip/dialogue/1203.htm.

. 'Propuestas Para la Paz'. In Debate. Guatemala: FLACSO, 1995.

Ashley, Richard K. 'The Poverty of Neorealism'. International Organization 38, no. 2 (1984): 225-86. 
'Untying the Sovereign State: A Double Reading of the Anarchy Problematique'. Millennium: Journal of International Studies 17, no. 2 (1988): 227-62.

Asociación Gremial de Exportadores de Productos No Tradicionales. [cited 21 March 2002]. Available from http://www.agexpront.com/ingles.htm.

Augelli, Enrico, and Craig Murphy. America's Quest for Supremeacy and the Third World. London: Pinter, 1988.

Aviel, JoAnn Fagot. 'NGOs and the Rule of Law in El Salvador and Guatemala'. Paper presented at the International Studies Association Annual Meeting, Los Angeles 2000.

Avineri, Shlomo, ed. Karl Marx on Colonialism and Modernisation. New York, 1969.

Aybar de Soto, José M. Dependency and Intervention: The Case of Guatemala in 1954. Boulder: Westview Press, 1978.

Azpuru, Dinorah. 'Peace and Democratization in Guatemala'. In Comparative Peace Processes in Latin America, edited by Cynthia Arnson, 97-126. Stanford: Stanford University Press, 1999.

Bagley, Bruce Michael. 'Contadora: The Failure of Diplomacy'. Journal of Interamerican Studies and World Affairs 28, no. 3 (1986): 1-32.

Bahl, Roy W., Jorge Marinez-Vasquez, and Sally Wallace. The Guatemalan Tax Reform. Boulder: Westview Press, 1996.

Baker, G. 'The Taming of the Idea of Civil Society'. Democratization 6, no. 3 (1999): 1-29.

Bakker, Isabella. 'Neoliberal Governance and the Reprivatization of Social Reproduction'. Paper presented at the British International Studies Association, Annual Meeting, Edinburgh, 17-19 December 2001.

Banuri, Tariq. 'Development and the Politics of Knowledge: A Critical Interpretation of the Social Role of Modernization Theories in the Development of the Third World'. In Dominating Knowledge: Development, Culture and Resistance, edited by Federique Apffel Marglin and Stephen A. Marglin, 29-72. Oxford: Oxford University Press, 1990.

' Modernization and its Discontents: A Cultural Perspective on the Theories of Development'. In Dominating Knowledge: Development, Culture and Resistance, edited by Federique Apffel Marglin and Stephen A. Marglin, 7295. Oxford: Oxford University Press, 1990.

Baranyi, Stephen. 'The Challenge in Guatemala: Verifying Human Rights, Strengthening National Institutions and Enhancing an Integrated UN Approach to Peace'. 31. London: The Centre for the Study of Global Governance (London School of Economics), 1995.

. 'The People's Peace: Civil Society Organisations and Peace Processes in the South'. 16. London: Catholic Institute for International Relations, 1998. 
. 'UN Verification: Achievements, Limitations and Prospects'. In Central America: Fragile Transition, edited by Rachel Sieder, 247-70. London: Macmillan, 1996.

Baranyi, Stephen, and Liisa North. 'Stretching the Limits of the Possible: United Nations P eacekeeping in C entral A merica'. 60. Ottawa: $\mathrm{C}$ anadian $\mathrm{C}$ entre for Global Security, 1992.

Barrett, Michèle. The Politics of Truth: From Marx to Foucault. Stanford: Stanford University Press, 1991.

Barry, Andrew, Thomas Osborne, and Nikolas Rose, eds. Foucault and Political Reason: Liberalism, Neo-liberalism and Rationalities of Government. London: UCL Press, 1996.

- 'Introduction'. In Foucault and Political Reason: Liberalism, neo-liberalism and rationalities of government, edited by Andrew Barry, Thomas Osborne and Nikolas Rose, 1-18. London: UCL Press, 1996.

Bar-Yaacov, Nomi. 'Diplomacy and Human Rights: The Role of Human Rights in Conflict Resolution in El Salvador and Haiti.' The Fletcher Forum of World Affairs 19, no. 2 (1995): 47-63.

Base de Datos Políticos de las Américas. Guatemala: Ley Electoral y de Partidos Políticos de 1985 Georgetown University y Organización de Estados Americanos, 1999 [cited 29 August 2003]. Available from http://www.georgetown.edu/pdba/Electoral/Guate/gley.html.

Bates, Thomas R. 'Gramsci and the Theory of Hegemony'. Journal of the History of Ideas 36, no. 2 (1975): 351-66.

Beckett, Ian F. W. Modern Insurgencies and Counter-Insurgencies: Guerrillas and Their Opponents Since 1750. New York: Routledge, 2001.

Bell, Vikki. 'The Promise of Liberalism and the Performance of Freedom'. In Foucault and Political Reason: Liberalism, Neo-liberalism and Rationalities of Government, edited by Andrew Barry, Thomas Osborne and Nikolas Rose, 8198. London: UCL Press, 1996.

Bellamy, Richard. 'A Crocean Critique of Gramsci on Historicism, Hegemony and Intellectuals'. Journal of Modern Italian Studies 6, no. 2 (2001): 209-29.

- 'Gramsci, Croce and the Italian Political Tradition'. History of Political Thought 11, no. 2 (1990): 313-37.

Bello, Walden. 'Prospects for Good Global Governance: A View from the South'. Focus on the Global South, 2002.

Bennett, Tony. Culture, Ideology and Social Processes. London: Open University Press, 1981.

Berger, Mark T. 'The Nation-State and the Challenge of Global Capitalism'. Third World Quarterly 22, no. 6 (2001): 889-907. 
- 'The Reconquest of Central America: Latin American Studies and the Transition to Democracy, 1979-1990'. Latin American Perspectives 24, no. 1 (1997): 7-72.

Bevir, Mark. 'Foucault and Critique: Deploying Agency against Autonomy'. Political Theory 27, no. 1 (1999): 65-84.

Biekart, Kees. The Politics of Civil Soceity Building: European Private Aid Agencies and Democratic Transitions in Central America. Utrecht: International Books, 1999.

Bieler, Andreas, and Adam David Morton. 'Globalisation, the State and Resistance: A "Critical Economy” Engagement with Open Marxism'. Paper presented at the British International Studies Association, Annual Meeting, Edinburgh, 17-19 December 2001.

Bilgin, Pinar, and Adam David Morton. 'Historicising Representations of 'Failed States': Beyond the Cold-War Annexation of the Social Sciences?' Third World Quarterly 23, no. 1 (2002): 55-80.

Birchfield, Vicki. 'Contesting the Hegemony of Market Ideology: Gramsci's 'Good Sense' and Polanyi's 'Double Movement'. Review of International Political Economy 6, no. 1 (1999): 27-54.

Blaney, David, and Naeem Inayatullah. 'International Political Economy as a Culture of Competition'. In Culture in World Politics, edited by Dominique JacquinBerdal, Andrew Oros and Marco Verweij, 61-88. New York: St. Martin's, 1998.

Blaney, David L., and Naeem Inayatullah. 'Neo-Modernization? IR and the Inner Life of Modernization Theory'. European Journal of International Relations 8, no. 1 (2002): 103-37.

. 'The Problem of Comparison or the Two-Handed Choke: International Relations and Modernization Theory as Mutually Constitutive of the Modern Political Imagination'. Paper presented at the International Studies Association Annual Meeting, Los Angeles 2000.

Blaufarb, Douglas S. The Counterinsurgency E ra: US Doctrine and Performanmce, 1950 to the Present. New York: The Free Press, 1977.

Boggs, Carl. The Two Revolutions: Antonio Gramsci and the Dilemmas of Western Marxism. Boston: South End Press, 1984.

Bonachea, Rolando E., and Nelson P. Valdes, eds. Ché: Selected Works of Ernesto Guevara. Cambridge: MIT Press, 1969.

Boneo, Horacio, and Edelberto Torres Rivas. ¿¿Por Qué no Votan los Guatemaltecos? Estudio de Participación y Abstención Electoral'. 210. Guatemala: Tribunal Supremo Electoral, 2001.

Booth, John A. 'Global Forces and Regime Change: Guatemala in the Central American Context'. Journal of Interamerican Studies and World Affairs 42, no. 2 (2000): 59-87. 
Bossier, S. 'Decentralization and Equity'. CEPAL Review, no. 46 (1992): 105-23.

Boutros-Ghali, Boutros. 'An Agenda for Peace: Preventive Diplomacy, Peacemaking and Peace-keeping'. New York: United Nations, 1992.

Bowles, Samuel, and Herbert Gintis. 'The Revenge of Homo Economicus: Contested Exchange and the Revival of Political Economy'. The Journal of Economic Perspectives 7, no. 1 (1993): 83-102.

Boyce, James K. 'Aid Conditionality as a Toll for Peacebuilding: Opportunities and Constraints'. Development and Change 33, no. 5 (2002): 1025-84.

, ed. Economic Policy for Building Peace: The Lessons of El Salvador. Boulder: Lynne Rienner, 1996.

. 'El Salvador's Adjustment Toward Peace: An Introduction'. In Economic Policy for Building Peace: The Lessons of El Salvador, edited by James K. Boyce, 1-17. Boulder: Lynne Rienner, 1996.

Boyce, James K., and Manuel Pastor Jr. 'Aid for Peace: Can International Financial Institutions Help Prevent Conflict?' World Policy Journal 15, no. 2 (1998): 4249.

Brigg, Morgan. 'Post-Development, Foucault and the Colonisation Metaphor'. Third World Quarterly 23, no. 3 (2002): 421-36.

Brightman, Carol, and Michael Klare. 'Social Research and Counterinsurgency: The Science of Neocolonialism'. In Subliminal Warfare: The Role of Latin American Studies. New York: North American Congress on Latin America, 1972.

Broadhead, Lee-Anne. 'Beyond the Traditions: Casting a Critical Light on Peace Research'. In Issues in Peace Research 1997-98, edited by Lee-Anne Broadhead. Bradford: University of Bradford Department of Peace Studies, 1997.

Brockett, Charles D. Land, Power and Poverty: Agrarian Transformation and Political Conflict in Central America. Edited by Gilbert W. Merkx, Thematic Studies in Latin America. Boston: Unwin Hyman, 1988.

Brody, Reed, Smita Narula, Arvind Ganesan, Joe Stork, Joseph Buttigieg, Jacinda Swanson, and Neve Gordon. 'Human Rights and Global Capitalism: A Roundtable Discussion with Human Rights Watch'. Rethinking Marxism 13, no. 2 (2001): 52-71.

Brysk, Alison. From Tribal Village to Global Village. Stanford: Stanford University Press, 2000.

Buchanan, James. 'Guatemala Under the FRG: Peace at a Crossroads'. 11. Ottawa: Canadian Foundation for the Americas, 2000.

Bulmer-Thomas, Victor. 'The Central American Common Market: From Closed to Open Regionalism'. World Development 26, no. 2 (1998): 313-22. Distribution and Poverty. London: Institute for Latin American Studies, 1996. 
The Political Economy of Central America since 1920. Cambridge: Cambridge University Press, 1987.

Burawoy, Michael. 'For a Sociological Marxism: The Complementary Convergence of Antonio Gramsci and Karl Polanyi'. Politics and Society 31, no. 2 (2003): 193261.

Burchell, Graham, Colin Gordon, and Peter Miller, eds. The Foucault Effect: Studies in Governmentality. London: Harvester Wheatsheaf, 1991.

Burgerman, Susan D. 'Building the Peace by Madating Reform: United NationsMediated Human Rights Agreements in El Salvador and Guatemala'. Latin American Perspectives 27, no. 3 (2000): 63-87.

Burgos, Raúl. 'The Gramscian Intervention in the Theoretical and Political Production of the Latin American Left'. Latin American Perspectives 29, no. 1 (2002): 937.

Burton, John W. 'Conflict Resolution as a Political Philosophy'. In Conflict Resolution Theory and Practice, edited by Dennis J. D. Sandole and Hugo van der Merwe, 55-64. Manchester: Manchster Univerity Press, 1993.

Bush, Archer Corbin. Organized Labor in Guatemala, 1944-1949: A Case Study of an Adolescent Labor Movement in an Underdeveloped Country. Hamilton, NY: Colgate University, 1950.

Byrne, Hugh. 'The First Nine Months of the Guatemalan Peace Process: High Expectations and Daunting Challenges'. 15. Washington, DC: Washington Office on Latin America, 1997.

CACIF. 'Comunicade del CACIF en Ottawa'.

. 'Guatemala: Plan de Desarrollo Economico y Social'. 69. Guatemala: CACIF, 2000.

Cambranes, Julio Castellanos. Coffee and Peasants: The Origins of the Modern Plantation Economy in Guatemala, 1853-1897. S tockholm: Institute of L atin American Studies, 1985.

Carbonnier, Gilles. 'The Competing Agendas of Economic Reform and Peace Process: A P olitico-Economic Model A pplied to Guatemala'. World Development 30 , no. 8 (2002): 1323-39.

. 'Conflict, Postwar Rebuilding and the Economy'. 84. Geneva: United Nations Research Institute for Social Development, 1998.

Carmack, Robert M., ed. Harvest of Violence: the Maya Indians and the Guatemalan Crisis. Norman: University of Oklahoma Press, 1988.

Carvajal, Eduardo Palma. 'Decentralization and Democracy: The New Latin American Municipality’. CEPAL Review, no. 55 (1995): 39-53.

Castro, Alfonso Peter, and Kreg Ettenger. 'Counterinsurgency and Socioeconomic Change: the Mau Mau War in Kirinyaga Kenya'. Research in Economic Anthropology 15 (1994): 63-101. 
Cavalcati, Pedro, and Paul Piccone, eds. History, Philosophy and Culture in the Young Gramsci. St. Louis: Telos Press, 1975.

Central America Report. 'International Community Rejects, Condemns and Isolates Serrano'. Central America Report, 4 June 1993, 158-9.

'Last Minute Consensus'. Central America Report, 11 June 1993, 165-6.

'New Framework for Integration'. Central America Report, 12 February 1993, 33-35.

'ORPA Kidnapping Revealed; Peace Talks on Hold'. Central America Report, 31 October 1996, 1-3.

'Peace Negotiations Still in Limbo'. Central America Report, 7 November 1996, 4-5.

'The Political Landscape'. Central America Report, 23 April 1993, 105-6.

Chase-Dunn, Christopher. 'Guatemala in the Gobal System'. Journal of Interamerican Studies and World Affairs 42, no. 2 (2000): 109-26.

Chernick, Marc W. 'Peacemaking and Violence in Latin America'. In The International Dimensions of Internal Conflict, edited by Michael E. Brown, 267-307. Cambridge, MA: MIT Press, 1996.

Chilcote, Ronald H. 'Post-Marxism: The Retreat from Class in Latin America'. Latin American Perspectives 17, no. 2 (1990): 3-24.

Clegern, Wayne M. Origins of Liberal Dictatorship in Central America: Guatemala, 1865-1873. Niwot, CO: University Press of Colorado, 1994.

Clements, Kevin. Towards Conflict Transfomation and a Just Peace Berghof Research Center for Constructive Conflict Management, 2001 [cited 29 Sept. 2003]. Available from www.berghof-center.org.

Clerc, Valerie. 'The Rehabilitation of War-Torn Societies: A Bibliography'. 17. Geneva: Centre for Applied Studies in International Negotiations (CASIN), 2000.

Cojti, Demetrio. 'Education Reform in Guatemala: The Lessons of Indigenous Involvement and Negotiations between Indigenous Civil Society and the State'. Paper p resented at the P luricultural and Multiethnic: E valuating Implications for State and Society in Mesoamerica and the Andes, London 2000.

Colburn, Forrest D., and Fernando F. Sánchez. Empresarios Centroamericanos y Apertura Económica. San José, Costa Rica: Educa, 2000.

Collinson, Helen. 'Humanising Peace: The Impact of Peace Agreements on Human Rights'. 14. London: Catholic Institute for International Relations, 1999.

Comas-Diaz, Lillian, M. Brinton Lykes, and Renato D. Alarcon. 'Ethnic Conflict and the Psychology of Liberation in Guatemala, Peru, and Puerto Rico'. American Psychologist 53, no. 7 (1998): 778-92.

CONIC. 'Ajtikonel”. Guatemala: CONIC, 2001. 
Costello, Patrick. 'Historical Background'. In Negotiating Rights: The Guatemalan Peace Process, edited by Jeremy Armon, Rachel Sieder and Richard Wilson. London: Concilliation Resources, 1997.

Cox, Robert W. 'Gramsci, Hegemony and International Relations: An Essay in Method'. Millennium 12, no. 2 (1983): 162-75.

. 'Gramsci, Hegemony and International Relations: An Essay in Method'. In Gramsci, Historical Materialism and International Relations, edited by Stephen Gill, 49-67. Cambridge: Cambridge University Press, 1993.

. 'Ideologies and the New International Economic Order: Reflections on Some Recent Literature'. International Organization 33, no. 2 (1979): 257-302.

- Production, Power and World Order: Social Forces in the Making of History. 4 vols. Vol. 1, Power and Production. New York: Columbia University Press, 1987.

- 'Social Forces, States and World Orders: Beyond International Relations Theory'. Millennium 10, no. 2 (1981): 126-55.

. 'Structual Issues of Global Governance: Implications for Europe'. In Gramsci, Historical Materialism and International Relations, edited by Stephen Gill, 259-89. Cambridge: Cambridge University Press, 1993.

Cox, Robert W., and Timothy J. Sinclair. Approaches to World Order. Vol. 40, Cambridge Studies in International Relations. Cambridge: Cambridge University Press, 1996.

Croce, Benedetto. Etica e politica. Bari: Laterza, 1931.

. Politics and Morals. Translated by Salvatore J. Castiglione. New York: Philosophical Library, 1945.

Cullather, Nick. Secret HIstory: The CIA's Classified Account of its Operations in Guatemala, 1952-1954. Stanford: Stanford University Press, 1999.

Dahl, Robert. Polyarchy: Participation and Opposition. New Haven: Yale Univeristy Press, 1971.

Davidson, Alastair. Antonio Gramsci: Towards an Intellectual Biography. London: Merlin Press, 1977.

'Gramsci and Lenin 1917-1922'. In The Socialist Register 1974, edited by Ralph Miliband and John Saville, 125-50. London: Merlin Press, 1974.

Davies, Howard, and Paul Ellis. 'Porter's Competitive Advantage Of Nations: Time For The Final Judgement?' Journal of Management Studies 37, no. 8 (2000): 1189-213.

de Giovanni, Bagio. 'Lenin and Gramsci: State, Politics and Party'. In Gramsci and Marxist Theory, edited by Chantal Mouffe, 259-88. London: Routledge and Kegan Paul Ltd., 1979.

de Janvry, Alain. The Agrarian Question and Reformism in Latin America. Baltimore: Johns Hopkins University Press, 1981. 
de Soto, Alvaro, and Graciana del Castillo. 'Obstacles to Peacebuilding'. Foreign Policy 94 (1994): 69-83.

Dean, Mitchell. Governmentality: Power and Rule in Modern Society. London: Sage, 2001.

Debray, Régis. The Revolution on Trial: A Critique of Arms. Translated by Rosemary Sheed. 2 vols. Vol. 2. New York: Penguin Books, 1978.

Defensoria Maya. 'Nociones del Derecho Maya'. Guatemala: Defensoria Maya, 2000.

Deininger, Klaus, and $\mathrm{H}$ ans Binswagner. 'The Evolution of the World Bank's L and Policy: Principles, Experience, and Future Challenges'. The World Bank Research Observer 14, no. 2 (1999): 247-76.

del Val, José. 'Desde las Políticas Indigenistas'. América Indígena 57, no. 1-2 (1997): 105-22.

Denizer, Cevdet, Raj M. Desai, and Nikolay Gueorguiev. 'The Political Economy of Financial Repression in Transition Economies'. Washington, DC: World Bank, 1998.

Diamond, Larry, Jonathan Hartlyn, Juan J. Linz, and Seymour Martin Lipset, eds. Democracy in Developing Countries: Latin America. 2nd ed. Boulder: Lynne Rienner, 1999.

Dillon, $\mathrm{M}$ ichael, and Ju lian R eid. ' Global Liberal Governance: Biopolitics, S ecurity and War'. Millennium 30, no. 1 (2000): 41-67.

Dolinsky, Gerardo Timossi, and trans. Sarah Stookey. 'Debt and Structural Adjustment in Central America'. Latin American Perspectives 17, no. 4 (1990): 76-90.

Donnelly, Jack. 'Human Rights: A New Standard of Civilization?' International Affairs 74, no. 1 (1998): 1-24.

Donzelot, Jacques. 'Pleasure in Work'. In The Foucault Effect: Studies in Governmentality, edited by Graham Burchell, Colin Gordon and Peter Miller, 251-80. London: Harvester Wheatsheaf, 1991.

Dosal, Paul J. Doing Business with the Dictators: A Political History of United Fruit in Guatemala 1899-1944. Wilmington, DE: Scholarly Resources, 1993.

- Power in Transition: The Rise of Guatemala's Industrial Oligarchy, 18711994. Westport, CT: Praeger, 1995.

Doty, Roxanne Lynn. 'The Bounds of 'Race' in International Relations'. Millennium: Journal of International Studies 22, no. 3 (1993): 443-62.

Drago, Tito. 'Arias Wins Spain's Backing for Peace Plan'. Inter Press Service, 14 May 1987.

Drake, Mike. 'They Made a Desert and Called it Peace'. Sociological Research Online 4, no. 2 (1999).

Duffield, Mark. 'Aid Policy and Post-Modern Conflict'. 104. Birmingham: The School of Public Policy, The University of Birmingham, 1998. 
Global Governance and the New Wars. London: Zed Books, 2001.

Duménil, Gérard, and Dominque Lévy. 'The Nature and Contradictions of Neoliberalism'. In Socialist Register 2002: A World of Contradictions, edited by Leo Panitch and Colin Leys. Black Point, Nova Scotia: Fernwood, 2002.

Dunkerley, James. 'Guatemala'. In Cambridge History of Latin America, edited by Leslie Bethell, 690-93. Cambridge: Cambridge University Press, 1995.

- 'Guatemala Since 1930'. In Cambridge History of Latin America, edited by Leslie Bethell, 211-49. Cambridge: Cambridge University Press, 1990.

. The Pacification of Central America. London: Institute of Latin American Studies, 1993.

- Power in the Isthmus: A Political History of Modern Central America. London: Verso, 1988.

Dunkerley, James, and Rachel Sieder. 'The Military: The Challenge of Transition'. In Central America: Fragile Transition, edited by Rachel Sieder, 55-102. London: Macmillan, 1996.

Dwan, Renata. 'Armed Conflict Prevention, Management and Resolution'. In SIPRI Yearbook, 69-127. London: Oxford University Press, 2001.

- 'Armed Conflict Prevention, Management and Resolution'. In SIPRI Yearbook, 97-150. London: Oxford University Press, 2002.

Equipo de A ntropoloígia Forense de Guatemala. Las Masacres en Rabinal. 2 nd ed. Guatemala: EAFG, 1997.

Erikssson, John. 'The Drive to Partnership: Aid Coordination and the World Bank'. 57. Washington, DC: World Bank, 2001.

Escobar, Arturo. 'Discourse and Power in Development: Michel Foucault and the Relevance of his Work to the Third World'. Alternatives 10 (1984-85): 377400 .

Escoto, Jorge, and Manfredo Marroquín. La AID en Guatemala. Managua: CRIES, 1992.

Esquit Choy, Alberto, and Víctor Gálvez Borrell. The Mayan Movement Today. Guatemala: FLACSO, 1997.

Falla, Ricardo. Massacres in the Jungle: Ixcán, Guatemala, 1975-1982. Translated by Julia Howland. Boulder: Westview Press, 1994.

Feinberg, Richard E., ed. Central America, International Dimensions of the Crisis. New York: Holmes and Meier, 1982.

Feinberg, Richard E. 'The Changing Relationship Between the World Bank and the International Monetary Fund'. International Organization 43, no. 3 (1988): $545-60$.

Femia, Joseph. 'Hegemony and Consciousness in the Thought of Antonio Gramsci'. Political Studies 23, no. 1 (1975): 75-93. 
Fetherston, A. B., and A. C. Parkin. 'Transforming Violent Conflict: Contributions from Social Theory'. Issues in Peace Research 1997-98 (1997): 19-58.

Fine, Ben. 'The Developmental State is Dead-Long Live Social Capital?' Development and Change 30 (1999): 1-19.

. 'Social Policy and Development: Social Captial as a Point of Departure'. 18. Geneva: United Nations Research Institute for Social Development programme on Social Policy and Development, 2002.

Fiori, Guiseppe. Antonio Gramsci: Life of a Revolutionary. Translated by Tom Narin. New York: E.P. Dutton \& Co., 1971.

Fontana, Benedetto. 'Logos and Kratos: Gramsci and the Ancients on Hegemony'. Journal of the History of Ideas 61, no. 2 (2000): 305-26.

Forgacs, David, ed. A Gramsci Reader: Selected Writings 1916-1935. London: Lawrence and Wishart, 1988.

Forster, Cindy. The Time of Freedom: Campesino Workers in Guatemala's October Revolution. Pittsburgh: University of Pittsburgh Press, 2001.

Foucault, Michel. The Archeology of Knowledge. London: Routledge, 1997.

. 'The Confession of the Flesh'. In Power / Knowledge: Selected Interviews and Other Writings 1972-1977, edited by Colin Gordon. Brighton: Harvester Press, 1980.

- Discipline and Punish: The Birth of the Prison. Translated by Alan Sheridan. London: Penguin, 1979.

- 'The Ethic of Care for the Self as a Practice of Freedom'. In The Final Foucault, edited by J. Bernauer and D. Rasmussen, 1-20. Boston: MIT Press, 1988.

. 'Governmentality'. In The Foucault Effect: Studies in Governmentality, edited by Graham Burchell, Colin Gordon and Peter Miller, 87-118. London: Harvester Wheatsheaf, 1991.

The History of Sexuality (Vol.1). Harmondsworth: Penguin, 1981.

. "Omnes et Singulatim': Towards a Criticism of 'Political Reason". In The Tanner Lectures on Human Values, edited by Sterling M. McMurrin, 223-54. Salt Lake City: University of Utah Press, 1981.

- The Order of Things. London: Routledge, 2002.

Power. Translated by Robert Hurley and others. Edited by James D. Faubion. Vol. 3, Essential Works of Foucault 1954-1984. New York: The New Press, 2000.

"Society Must Be Defended": Lectures at the Collège de France 1975-1976.

Translated by David Macey. Edited by Mauro Bertani and Alessandro Fontana.

New York: Picador, 2003. 
Frank, L ouisa. 'Resistance and Revolution: The D evelopment of A rmed S truggle in Guatemala'. In Guatemala, edited by Susanne Jonas and David Tobis, 176-92. Berkeley, CA: North American Congress on Latin America, 1974.

Frente Republicano Guatemalteco. Código de Honor [cited 29 August 2003]. Available from http://www.frg.org.gt/codigo-de-honor.htm.

- Historia [cited 29 August 2003]. Available from http://www.frg.org.gt/historia-frg.htm.

- Postulados [cited 29 August 2003]. Available from http://www.frg.org.gt/postulados-sociales.htm.

. Principios Fundamentales [cited 29 August 2003]. Available from http://www.frg.org.gt/principios-fundamentales.htm.

—. Principios Ideológicos [cited 29 August 2003]. Available from http://www.frg.org.gt/principios-ideologicos.htm.

FRG. 1995 Election Platform 2001 [cited April 2001]. Available from http://www.agora.stm.it/elections/election/guatemal.htm.

Gallie, W. B. 'Essentially Contested Concepts'. Aristotelian Society, no. 56 (1956): 167-98.

Galtung, Johan. 'Cultural Violence'. Journal of Peace Research 27, no. 3 (1990): 291305.

. 'The Next Twenty-five Years of Peace Research: Tasks and Prospects'. In Peace Research: Achievements and Challenges, edited by Peter Wallensteen, 242-63. Boulder: Westview, 1988.

'Violence, Peace and Peace Research'. Journal of Peace Research 3 (1969): 167-92.

Gamble, Nicole. 'Ex-Dictator's Candidacy Threatens Justice in Guatemala Genocide Trials'. 3. Silver City, NM: Interhemisphere Resource Center, 2003.

Gamboa M., Nuria , and Barbara Trentavizi. La Guatemala Posible: La Senda del Pacto Fiscal. Guatemala: Asociación Centroamericana Hombres de Maíz, 2001.

Garcia, Sergio Mendizábal. 'Nuevos Sujetos Políticos en Guatemala'. América Indígena 57, no. 1-2 (1997): 105-22.

Gargarella, Roberto. 'Recientes Reformas Constitucionales en America Latina: Una Primera Aproximacion'. Desarrollo Economico - Revista de Ciencias Sociales 36, no. 144 (1997): 971-90.

Garrett, John R. 'Policies for Peace: An Analysis of the Causes of Military Expenditures and the Means to Disarmament'. In Economics of Conflict and Peace, edited by Jurgen Brauer and William G. Gissy, 355-73. Aldershot: Avebury, 1997.

Garst, Rachel. 'The New Guatemalan National Civilian Police: A Problematic Beginning'. 12. Washington, DC: Washington Office on Latin America, 1997. 
Gendzier, Irene L. Managing Political Change: Social Scientists and the Third World. Boulder: Westview Press, 1985.

Germain, Randall D., and Michael Kenny. 'Engaging Gramsci: International Relations Theory and the N ew Gramscians'. R eview of International Studies 24, no. 1 (1998): 3-21.

Ghosh, Peter. 'Gramscian Hegemony: An Absolutely Historicist Aproach'. History of European Ideas 27, no. 1 (2001): 1-43.

Gill, Stephen. 'Cautionary Reflections on Seattle'. Millennium: Journal of International Studies 29, no. 1 (2000): 131-40.

'Epistemology, Ontology, and the 'Italian School". In Gramsci, Historical Materialism and International Relations, edited by Stephen Gill, 21-48. Cambridge: Cambridge University Press, 1993.

- 'Globalisation, Market Civilisation, and Disciplenary Neoliberalism'. Millennium: Journal of International Studies 23, no. 3 (1995): 399-423.

ed. Gramsci, Historical Materialism and International Relations. Cambridge: Cambridge University Press, 1993.

. 'Gramsci, Modernity and Globalization'. Paper presented at the Gramsci and the Twentieth Century, Sardinia 1997.

. Power and Resistance in the New World Order. Basingstoke: Palgrave Macmillan, 2003.

- 'The Redefinition of the Political under New Constitutionalism: Constitutionalizing Inequality and the Clash of Globalizations'. Paper presented at the British International Studies Association, Annual Meeting, Edinburgh, 17-19 December 2001.

Gill, Stephen, and David Law. 'Global Hegemony and the Structural Power of Capital'. In Gramsci, Historical Materialism and International Relations, edited by Stephen Gill, 93-124. Cambridge: Cambridge University Press, 1993.

. 'Global Hegemony and the Structural Power of Capital'. International Studies Quarterly 33, no. 4 (1989): 475-99.

Ginifer, Jeremy. 'Development and the UN Peace Mission: A New Interface Required?' International Peacekeeping 3, no. 2 (1996): 3-16.

Girling, John. Capital and Power: Political Economy and Social Transformation. London: Croom Helm, 1987.

Glade, WP. 'Latin America in the International Economy'. In Cambridge History of Latin America vol. IV, edited by Leslie Bethell, 1-56. Cambridge: Cambridge University Press, 1986.

Gleijeses, Piero. Shattered Hope: The Guatemalan Revolution and the United States, 1944-1954. Princeton: Princeton University Press, 1991.

Gobierno de Guatemala. 'Cronica de Gobierno: Balance de 1996-1998'. Guatemala. 
Godoy, Ju lio. 'Duarte, A rias V isits End Y ear of D iplomatic S uccesses'. Inter Press Service, 4 December 1987.

Goldfrank, Walter L. 'Paradigm Regained? The Rules of Wallerstein's World-System Method'. Journal of World-Systems Research 6, no. 2 (2000): 150-95.

Goldin, Liliana R. 'Work and Ideology in the Maya Highlands of Guatemala: Economic Beliefs in the Context of Occupational Change'. Economic Development and Cultural Change (1992).

González, Matilde. 'The Man Who Brought Danger to the Village: Representations of Armed Conflict in Guatemala from a Local Perspective'. Journal of Southern African Studies 26, no. 2 (2000): 317-35.

Gordon, Colin. 'Governmental Rationality: An Introduction'. In The Foucault Effect: Studies in Governmentality, edited by Graham Burchell, Colin Gordon and Peter Miller. London: Harvester Wheatsheaf, 1991.

'Introduction'. In Power: Essential Works of Foucault 1954-1984, edited by James D. Faubion. New York: The New Press, 2000.

Power / Knowledge: Selected Interviews and Other Writings 1972-1977. Brighton: Harvester Press, 1980.

Gordon, Neve, Jacinda Swanson, and Joseph Buttigieg. 'Is the Struggle for Human Rights a Struggle for Emancipation?' Rethinking Marxism 12, no. 3 (1999): 122.

Goulding, Sir Marrack. 'Preface'. In Of Centaurs and Doves: Guatemala's Peace Process, edited by Susanne Jonas. Oxford: Westview Press, 2000.

Gramsci, Antonio. Il Materialismo Storico e la Filosofia di Benedetto Croce. 9th ed. Turin: Einaudi, 1972.

Selections from Cultural Writings. Translated by William Boelhower. Edited by David Forgacs and Geoffrey Nowell Smith. Cambridge, MA: Harvard University Press, 1985.

. Selections from the Political Writings 1910-1920. Translated by John Mathews. Edited by Quintin Hoare. London: Lawrence and Wishart, 1977.

Selections from the Political Writings 1921-1926. Translated by Quintin Hoare. Edited by Quintin Hoare. London: Lawrence and Wishart, 1978.

Selections from the Prison Notebooks of Antonio Gramsci. Translated by Quintin Hoare and Geoffrey Nowell Smith. Edited by Quintin Hoare and Geoffrey Nowell Smith. London: Lawrence and Wishart, 1991.

Gramsci, Antonio, and (Alfa Gamma). 'Il Grido del Popolo, 29 January 1916'. In $A$ Gramsci Reader: Selected Writings 1916-1935, edited by David Forgacs. London: Lawrence and Wishart, 1988.

Grandin, Greg. The Blood of Guatemala. Edited by Walter D. Minggnolo, Irene Silverblatt and Sonia Saldívar-Hull, Latin America Otherwise: Languages, Empires, Nations. Durham: Duke University Press, 2000. 
'To End With All These Evils: Ethnic Transformation and Community Mobilisation in Guatemala's Western Highlands, 1954-1980'. Latin American Perspectives 24, no. 93 (1997): 7-34.

Grant, Robert M. 'Porter's 'Competitive Advantage of Nations': An Assessment'. Strategic Management Journal 12, no. 7 (1991): 535-48.

Green, Linda. Fear as a Way of Life: Mayan Widows in Guatemala. New York: Columbia University Press, 1999.

. 'The Localization of the Global: Contemporary Production Practices in a Mayan Community in Guatemala'. In The third wave of modernization in Latin America: cultural perspectives on neoliberalism, edited by Lynne Phillips. Wilmington, DE: Scholarly Resources Inc., 1998.

Grieb, Kenneth J. Guatemalan Caudillo, The Regime of Jorge Ubico: Guatemala, 1931-1944. Athens: Ohio University Press, 1979.

Guha, Ranajit. Elementary Aspects of Peasant Insurgency in Colonial India. Delhi: Oxford University Press, 1983.

Hall, Stuart. 'Gramsci's Relevance for the Study of Race and Ethnicity'. In Stuart Hall: Critical Dialogues in Cultural Studies, edited by David Morley and Kuan-Hsing Chen, 411-40. London: Routledge, 1996.

Handy, Jim. Gift of the Devil: A History of Guatemala. Toronto: Between the Lines, 1984.

- Revolution in the Countryside: Rural Conflict and Agrarian Reform in Guatemala, 1944-1954. Chapel Hill: Univeristy of North Carolina Press, 1994.

Haug, Wolfgang Fritz. 'From Marx to Gramsci, from Gramsci to Marx: Historical Materialism and the Philosophy of Praxis'. Rethinking Marxism 13, no. 1 (2001): 69-82.

Haugaard, Lisa. To What Extent Have Military Reforms Taken Place in Guatemala? Guatemalan Scholars Network, 2000 [cited 12 February 2001]. Available from http;//www.vanderbilt.edu/AnS/Ant...what_extent_have_military_ref.htm.

Helweg-Larson, Simon. Guatemala Digest (October 17-22) 2003 [cited 29 October 2003]. Available from http://lists.riseup.net/www/info/guatemaladigest.

‘A New Beginning?' Latinamerica Press, 24 November 2003.

Hendrickson, Carol. 'Images of the Indian in Guatemala: The Role of Indigenous Dress in Indian and Ladino Constructions'. In Nations-states and Indians in Latin America, edited by Greg Urban and Joel Sherzer, 286-306. Austin: Univeristy of Texas Press, 1991.

Hindess, Barry. Discourses of Power: from Hobbes to Foucault. Oxford: Blackwell, 1996.

. 'Liberalism, Socialism and Democracy: Variations on a Governmental Theme'. In Foucault and Political Reason: Liberalism, neo-liberalism and rationalities of government, edited by Andrew Barry, Thomas Osborne and Nikolas Rose, 65-80. London: UCL Press, 1996. 
. 'On Three-Dimensional Power'. Political Studies 24, no. 3 (1976): 329-33.

Hirst, Paul. 'The Eighty Years' Crisis, 1919-1999 -- Power'. Review of International Studies 24, no. 5 (1998): 133-48.

Hoare, Quintin. 'Introduction to Selections from the Political Writings 1910-1920'. In Selections from the Political Writings 1910-1920 [of Antonio Gramsci], edited by Quintin Hoare. London: Lawrence and Wishart, 1977.

- 'Introduction to Selections from the Political Writings 1921-1926'. In Selections from the Political Writings 1921-1926 [of Antonio Gramsci], edited by Quintin Hoare. London: Lawrence and Wishart, 1978.

Hoare, Quintin, and Geoffrey Nowell Smith. 'Introduction to Selections from the Prison Notebooks of Antonio Gramsci'. In Selections from the Prison Notebooks of Antonio Gramsci, edited by Quintin Hoare and Geoffrey Nowell Smith. London: Lawrence and Wishart, 1991.

Hobsbawm, E.J. 'The Great Gramsci'. The New York Review of Books, April 4 1974, 39-44.

Hojman, David E. 'The Political Economy of Recent Conversions to Market Economics in Latin America'. Journal of Latin American Studies 26 (1994): 191-219.

Holden, Robert H. 'Constructing the Limits of State Violence in Central America: Towards a New Research Agenda'. Journal of Latin American Studies 28, no. 2 (1996): 435-59.

. 'The Real Diplomacy of Violence: United States Military Power in Central America, 1950-1990'. The International History Review 15, no. 2 (1993): 283322.

Holiday, David. 'Guatemala's Long Road to Peace'. Current History 96 (1997): 68-73.

Hoogvelt, Ankie, John Rees, Ken Coates, Paul Rogers, Martin Shaw, and Tunde SackWilliams. 'Debate: The New Wars'. New Political Economy 5, no. 1 (2000): 99-119.

Hopgood, Stephen. 'Reading the Small Print in Global Civil Society: the Inexorable Hegemony of the Liberal Self. Millennium: Journal of International Studies 29 , no. 1 (2000).

Horne, Gerald. 'Race from Power: U.S. Foreign Policy and the General Crisis of "White Supremacy". Diplomatic History 23, no. 3 (1999): 437-61.

Human Rights Office of the Archbishopric of Guatemala. "'Peace" Built on a Time Bomb'. Envio 16, no. 160 (1997): 18-22.

Human Rights Office of the Archdiocese of Guatemala. Guatemala: Never Again! Translated by Gretta Tovar Siebentritt. London: Catholic Institute for International Relations, 1999.

Human Rights Watch. 'Corporations and Human Rights: Freedom of Association in a Maquila in Guatemala'. Human Rights Watch 9, no. 3 (1997): 1-14. 
Huntington, Samuel P. The Clash of Civilizations and the Remaiking of World Order. New York: Simon \& Schuster, 1996.

—. 'The Clash of Civilizations?' Foreign Affairs 72, no. 3 (1993): 22-49.

Hyden, Goran. 'Civil Society, Social Capital, and Development: Dissection of a Complex Discourse'. Studies in Comparative International Development 32, no. 1 (1997): 3-30.

IDEA, International. 'Democracia en Guatemala'. Guatemala: International IDEA, 1999.

IMF. 'Guatemala: Recent Economic Developments'. Washington, DC: International Monetary Fund, 1998.

- 'Guatemala: Recent Economic Developments'. Washington, DC: International Monetary Fund, 1995.

. 'Guatemala: Recent Economic Developments - Supplementary Information'. Washington, DC: International Monetary Fund, 1998.

Immerman, Richard H. The CIA in Guatemala: The Foreign Policy of Intervention. Austin: University of Texas Press, 1982.

Inayatullah, Naeem, and David L. Blaney. 'Towards an Ethnological IPE: Karl Polanyi's Double Critique of Capitalism'. Millennium: Journal of International Studies 28, no. 2 (1999): 311-40.

Institute of European-Latin American Relations. 'Guatemala: Elections and Pacification'. 10. Madrid: Institute of European-Latin American Relations, 1995.

Inter-American Development Bank. Preinvestment Program for Peace: Executive Summary [cited 6 August 2001]. Available from http://www.iadb.org/EXR/doc98/apr/gu1106e.htm.

Project to Promote Private Sector Participation in Technical Training in Rural Areas 1997 [cited 6 August 2001]. Available from http://www.iadb.org/EXR/doc98/apr/gu5736e.htm.

' Summary of Internationally Financed Projects: D ocument p resented to the members of the Consultative Group of Guatemala'. Washington, DC: InterAmerican Development Bank, 2002.

Technical Cooperation to Support the Development of a Securities Registry for Guatemala's Capital Markets 1997 [cited 6 August 2001]. Available from http://www.iadb.org/EXR/doc98/apr/gu5783e.htm.

Jabri, Vivienne. Discourses on Violence: Conflict Analysis Reconsidered. Manchester: Manchester University Press, 1996.

Jackson Lears, T.J. 'The Concept of Cultural Hegemony: Problems and Possibilities'. The American Historical Review 90, no. 3 (1985): 567-93.

James, Martin, ed. Antonio Gramsci: Critical Assessments of Leading Political Philosophers. 4 vols. London: Routledge, 2002. 
Jenkins, Tony. 'Administration Strategy; One Last Chance for the Contras'. The Nation, 16 May 1987, 638-.

Jonas, Susanne. 'Contradictions of Revolution and Intervention in Central America in the Transnational Era: The Case of Guatemala'. In Revolution and Intervention in Central America, edited by Marlene Dixon and Susanne Jonas, 281-329. San Francisco: Synthesis Publications, 1983.

2. 'Democratization through Peace'. In Globalization on the Ground: Postbellum Guatemalan Democracy and Development, edited by Christopher Chase-Dunn, Susanne Jonas and Nelson Amaro. Lanham, MD: Rowman and Littlefield, 2001.

'Democratization Through Peace: the Difficult Case of Guatemala'. Journal of Interamerican Studies and World Affairs 42, no. 2 (2000): 9-38.

. 'Los Acuerdos de Paz: Un Fin y un Comienzo'. América Indígena 57, no. 1-2 (1997): 123-31.

'Masterminding the Mini-Market: U.S. Aid to the Central American Common Market'. In Guatemala, edited by Susanne Jonas and David Tobias: North American Congress on Latin America, 1974.

. Of Centaurs and Doves: Guatemala's Peace Process. Oxford: Westview Press, 2000.

."'Showcase" for Counterrevolution'. In Guatemala, edited by Susanne Jonas and David Tobis, 74-81. Berkeley, CA: North American Congress on Latin America, 1974.

Jonas, Susanne, and David Tobis, eds. Guatemala. Berkeley, CA: North American Congress on Latin America, 1974.

Kaldor, Mary. New and Old Wars: Organized Violence in a Global Era. Cambridge: Polity Press, 1999.

Kay, Cristóbal. 'For a Renewal of Development Studies: Latin American Theories and Neoliberalism in the Era of Structural Adjustment'. Third World Quarterly 14, no. 4 (1993): 691-702.

Kepner, Charles David. The Banana Empire: A Case Study of Economic Imperialism. New York: Russell and Russell, 1967.

Kesselman, Mark. 'Order or Movement?: The Literature of Political Development as Ideology’. World Politics 26, no. 1 (1973): 139-54.

Kincaid, A. Douglas. 'Demilitarization and Security in El Salvador and Guatemala: Convergences of Success and Crisis'. Journal of Interamerican Studies and World Affairs 42, no. 2 (2000): 39-58.

Kitson, Frank. Low Intensity Operations: Subversion, Insurgency, Peace-keeping. London: Faber and Faber, 1971.

Klor de Alva, J. Jorge. 'The Postcolonization of the (Latin) American Experience: A Reconsideration of "Colonialism", "Postcolonialism", and "Mestizaje". In 
After Colonialism: Imperial Histories and Postcolonial Displacements, edited by Gyan Prakash. Princeton: Princeton University Press, 1995.

Krznaric, Roman. 'Civil and Uncivil Actors in the Guatemalan Peace Process'. Bulletin of Latin American Studies Research 18, no. 1 (1999): 1-16.

Kukathas, Chandran. 'Are There Any Cultural Rights?' In The Rights of Minority Cultures, edited by Will Kymlicka, 228-55. Oxford: Oxford University Press, 1995.

Kumar, Krishna. 'The Nature and Focus of International Assistance for Rebuilding War-Torn Societies'. In Rebuilding Societies After Civil War: Critical Roles for International Assistance, edited by Krishna Kumar, 1-38. Boulder: Lynne Rienner, 1997.

Kurasawa, Fuyuki. 'The Exotic Effect: Foucault and the Question of Cultural Alterity'. European Journal of Social Theory 2, no. 2 (1999): 147-65.

Kymlicka, Will. Liberalism, Community, and Culture. Oxford: Clarendon, 1989.

La Rue, Frank. 'The Right to Truth in Central America'. In Impunity in Latin America, edited by Rachel Sieder, 73-81. London: University of London, Institute of Latin American Studies, 1995.

Laclau, Ernesto. 'Feudalism and Capitalism in Latin America'. New Left Review 1, no. 67 (1971): 19-38.

Laclau, Emesto, and Chantal Mouffe. Hegemony and Socialist Strategy: Towards a Radical Democratic Politics. 2nd ed. London: Verso, 2001.

LaFeber, Walter. Inevitable Revolutions: The United States in Central America. 2nd ed. New York: W.W. Norton \& Company, 1993.

Laguardia, Jorge Mario García. 'Derechos Humanos y Acuerdos de Paz'. América Indígena 57, no. 1-2 (1997): 77-87.

Lal, Deepak. The Poverty of 'Development Economics'. Second ed. Vol. 16, Hobart Paperback. London: Institute for Economic Affairs, 1997.

Lapid, Yosef, and Friedrich Kratochwil, eds. The Return of Culture and Identity in International Relations Theory. Boulder: Lynne Rienner, 1996.

Larner, Wendy. 'Neo-liberalism: Policy, Ideology, Governmentality'. Studies in Political Economy 63 (2000): 5-25.

Le Bot, Yvon. 'El Proceso de Paz en Guatemala'. América Indígena 57, no. 1-2 (1997): 7-26.

- La Guerre en Terre Maya: Communauté, Violence et Modernité au Guatemala, 1970-1992. Paris: Editions Karthala, 1992.

Lehman, Kenneth. 'Revolutions and Attributions: Making Sense of Eisenhower Administration Policies in Bolivia and Guatemala'. Diplomatic History 21, no. 2 (1997): 185-213. 
Lélé, Sharachchandra. 'Sustainable Development: A Critical Review'. World Development 19, no. 6 (1991): 607-21.

Lemke, Thomas. "The Birth of Bio-Politics': Michel Foucault's Lecture at the Collège de F rance on Neo-Liberal Governmentality'. Economy and Society 30, n o. 2 (2001): 190-207.

LeoGrande, William. 'Deciding to Intervene: The Reagan Doctrine and American Foreign Policy; Promoting Polyarchy: Globalization, US Intervention, and Hegemony'. The Journal of Politics 60, no. 1 (1998): 306-10.

Linklater, Andrew. Beyond Realism and Marxism: Critical Theory and International Relations. London: Macmillan, 1990.

Lipschutz, Ronnie D. 'Beyond the Neoliberal Peace: From Conflict Resolution to Social Reconciliation'. Social Justice 25, no. 4 (1998).

Liss, Sheldon B. Radical Thought in Central America. Edited by Ronald H. Chilcote. Vol. 7, Latin American Perspectives Series. Boulder: Westview Press, 1991.

Lodge, George Cabot. 'The Birth of INCAE (1963-1965): A View from Harvard'. ReVista, Fall 1999.

Louise, Christopher. 'MINUGUA's Peacebuilding Mandate in Western Guatemala'. International Peacekeeping 4, no. 2 (1997): 50-73.

Lowy, Michael. The Marxism of Ché Guevara: Philosophy, Economics and Revolutionary Warfare. Translated by Brian Pearce. New York: Monthly Review Press, 1973.

Lowy, Michael, Eder Sader, and Stephen Gorman. 'The Militarization of the State in Latin America'. Latin American Perspectives 12, no. 4 (1985): 7-40.

Lukes, Steven. Power: A Radical View. London: Macmillan, 1974.

Lutz, Christopher H., and W. George Lovell. 'Core and Periphery in Colonial Guatemala'. In Guatemalan Indians and the State, 1540 to 1988, edited by Carol Smith, 35-51. Austin: University of Texas Press, 1990.

Macdonald, Laura. 'Globalising Civil Society: Interpreting International NGOs in Central America'. Millennium 23, no. 2 (1994): 267-85.

Macdonald, Mandy, and et al. 'Europe and the Guatemalan peace process an analysis of European Union policy towards Guatemala, 1986-97'. 12. London: Catholic Institute for International Relations, 1998.

Macehling Jr., Charles. 'Counterinsurgency: The First Ordeal by Fire'. In LowIntensity Warfare: Counterinsurgency, Proinsurgency and Antiterrorism in the Eighties, edited by Michael K lare and P eter Kornbluh. N ew Y ork: P antheon Books, 1988.

MacLachlan, Colin M. Spain's Empire in the New World: The Role of Ideas in Institutional and Social Change. Berkeley: University of California Press, 1988. 
Macpherson, C.B. The Political Theory of Possessive Individualism. Oxford: Clarendon Press, 1962.

Macrae, Joanna, Mark Bradbury, Susanne Jaspars, Douglas Johnson, and Mark Duffield. 'Conflict, the Continuum and Chronic Emergencies: A Critical Analysis of the Scope for Linking Relief, Rehabilitation and Development Planning in Sudan'. Disasters 21, no. 3 (1997): 223-43.

Mallon, F lorencia E. 'The P romise and D ilemma of S ubaltern S tudies: Perspectives from Latin American History'. The American Historical Review 99, no. 5 (1994): 1491-515.

Mani, Rama. 'Do 'Root Causes' Really Matter? Distributive Justice in Post-Conflict Societies'. Paper presented at the British International Studies Association Annual Conference, University of Sussex 1998.

Mann, Michael. 'The Dark Side of Democracy: The Modern Tradition of Ethnic Cleansing'. New Left Review I, no. 235 (1999): 18-45.

Manz, Beatriz. Refugees of a Hidden War. Albany: State University of New York Press, 1988.

Manzo, Kate. 'Modernist Discourse and the Crisis of Development Theory'. Studies in Comparative International Development 26, no. 2 (1991): 3-36.

Marx, Karl. A Contribution to the Critique of Political Economy Marxists.org, 1859 [cited 17 June 2003]. Available from http://www.marxists.org/archive/marx/works/1859/critique-poleconomy/index.htm.

Marxist Internet Archive. [cited 15 July 2004]. Available from http://www.marxists.org/glossary/terms/c/i.htm\#civil-society.

Mato, D aniel. ' On G lobal and Local A gents and the S ocial Making of T ransnatinal Identities and Related Agendas in "Latin America". Identities 4, no. 2 (1997): 167-212.

McCleary, Rachel M. Dictating Democracy: Guatemala and the End of Violent Revolution. Gainesville, FL: University Press of Florida, 1999.

. 'Guatemala's Postwar Prospects'. Journal of Democracy 8, no. 2 (1997): 12942.

McClintock, Michael. The American Connection, Vol. II: State Terror and Popular Resistance in Guatemala. London: Zed Books, 1985.

McCreery, David. 'Coffee and Class: the Structure of Development in Liberal Guatemala'. Hispanic American Historical Review 56, no. 3 (1976): 438-60.

-. 'Debt Servitude in Rural Guatemala, 1876-1936'. Hispanic American Historical Review 63, no. 4 (1983): 735-59.

“An Odious Feudalism': Mandamiento Labor and Commercial Agriculture in Guatemala, 1858-1920'. Latin American Perspectives 13, no. 1 (1986): 99-117. 
. 'Wage Labor, Free Labor, and Vagrancy Laws: The Transition to Capitalism in Guatemala, 1920-1945'. In Coffee, Society, and Power in Latin America, edited by William Roseberry, Lowell Gudmundson and Mario Samper Kutschbach, 206-31. Baltimore: Johns Hopkins University Press, 1995.

McCuen, John J. The Art of Counter-Revolutionary War: The Strategy of CounterInsurgency. Harrisburg, PA: Stackpole Books, 1966.

McGrail, Steve. 'Decentralisation: New Power or New Privilege?' Community Development Journal 30, no. 2 (1995): 200-08.

McHoul, Alec, and Wendy Grace. A Foucualt Primer: Discourse, Power and the Subject. New York: New York Univeristy Press, 2000.

McLellan, David. Marxism After Marx. 3rd ed. Houndsmills: Macmillan, 1998.

McSherry, J. Patrice, and Raúl Molina Mejía. 'Introduction to "Shadows of State Terrorism: Impunity in Latin America"'. Social Justice 26, no. 4 (1999): 1-12.

Menchú, Rigoberta. I, Rigoberta Menchú: An Indian Woman in Guatemala. Translated by Ann Wright. London: Verson, 1984.

Milne, Simon, and Irena Ateljevic. 'Tourism, Economic Development and the GlobalLlocal Nexus: Theory Embracing Complexity'. Tourism Geographies 3, no. 4 (2001): 369-93.

MINUGUA. 'Cronicas de Minugua'. Guatemala, 2001.

. 'Executive Summary: MINUGUA Report to the Consultative Group meeting for Guatemala’. 5. Guatemala: MINUGUA, 2003.

. 'The Indigenous Peoples of Guatemala: Overcoming Discrimination in the Framework of the Peace Agreements'. Guatemala, 2001.

- 'Report for the Consultative Group meeting for Guatemala'. 21. Guatemala: MINUGUA, 2002.

. 'Status of the Commitments of the Peace Agreements Relating to the Armed Forces'. Guatemala, 2002.

Mitchell, C. R. The Structure of International Conflict. London: Macmillan, 1981.

Mitchell, Thomas G. 'The Internal Settlement: A Counterinsurgency Strategy'. Conflict Quarterly 12, no. 1 (1992): 7-24.

Mohan, Giles. 'Developing Differences: Post-structuralism and Political Economy in Contemporary Development Studies'. Review of African Political Economy 73 (1997): 311-28.

Molina Mejía, Raúl. 'The Struggle Against Impunity in Guatemala'. Social Justice 26, no. 4 (1999): 55-83.

Monsanto, Pablo. 'Discurso Pronunciado por el Comandante Pablo Monsanto en Nobre de la Comandancia General de la URNG, en el Acto de Firma del Acuerdo "Aspectos Socioeconomicos y Situacion Agraria". In Acuerdos de Paz: Aspectos Socioeconomicos y Situacion Agraria, edited by Asociacion de 
Investigacion y Estudios Sociales, 7-10. Guatemala: Asociacion de Investigacion y Estudios Sociales, 1996.

Montejo, Victor D. 'Convention 169 and the Implementation of the Peace Accords in Guatemala'. Abya Yala News 10, no. 4 (1997).

Moore, David. 'Leveling the Playing Fields and Embedding Illusions: 'Post-Conflict' Discourse and Neo-liberal 'Development' in War-torn Africa'. Review of African Political Economy, no. 83 (2000): 11-28.

Moreno, Dario. The Struggle for Peace in Central America. Gainsville: University of Florida Press, 1994.

Morley, David, and Kuan-Hsing Chen, eds. Stuart Hall: Critical Dialogues in Cultural Studies. Edited by David Morley, Comedia. London: Routledge, 1996.

Mouffe, Chantal, ed. Gramsci and Marxist Theory. London: Routledge and Kegan Paul Ltd., 1979.

. 'Hegemony and Ideology in Gramsci'. In Gramsci and Marxist Theory, edited by Chantal Mouffe, 168-204. London: Routledge and Kegan Paul Ltd., 1979.

Nairn, Tom. 'Antonu Su Gobbu'. In Approaches to Gramsci, edited by Anne Showstack Sassoon. London: Writers and Readers, 1982.

Naylor, Robert. 'Guatemala: Indian Attitudes Towards Land Tenure'. Journal of InterAmerican Studies 9 (1967): 619-39.

Nordquist, Joan, ed. Antonio Gramsci: A Bibliography, Social Theory: A Bibliographic Series. Santa Cruz, CA: Reference Research Services, 1987.

O'Donnell, Guillermo, Phillippe C. Schmitter, and Laurence Whitehead, eds. Transitions from Authoritarian Rule: Prospects for Democracy. Baltimore: Johns Hopkins University Press, 1986.

OECD. International Development: (ISSN 1608-1110) [cited 6 August 2003]. Available from www.sourceoecd.org.

Olson, Gary L. US Foreign Policy and the Third World Peasant: Land Reform in Asia and Latin America. New York: Praeger, 1974.

O'Malley, Pat, Lorna Weir, and Clifford Shearing. 'Governmentality, Criticism, Politics'. Economy and Society 26, no. 4 (1997): 501-17.

Padilla, Luis Alberto. 'Prevention Success and Failures: Peacemaking and Conflict Transformation in Guatemala'. 23. London: International Alert, 1997.

. 'Teoria de las Relaciones Internacional: La Investigacion s obre la $\mathrm{P}$ az y e 1 Conflicto'. Guatemala: IRIPAZ, 1992.

Paggi, L eonardo. 'Gramsci's General Theory of Marxism'. In Gramsci and Marxist Theory, edited by Chantal Mouffe, 113-67. London: Routledge and Kegan Paul Ltd., 1979.

Palencia Prado, Tania. 'Peace in the Making: Civil Groups in Guatemala'. 44. London:

Catholic Institute for International Relations, 1996. 
Palma Murga, Gustavo. 'Promised the Earth: Agrarian Reform in the Socio-Economic Agreement'. In Negotiating Rights: the Guatemalan Peace Process, edited by Jeremy Armon, Rachel Sieder and Richard Wilson, 74-80. London: Conciliation Resources, 1997.

PAN. 1995 Election Platform 2001 [cited April 2001]. Available from http://www.agora.stm.it/elections/election/guatemal.htm.

Parekh, Bhikhu. 'The Cultural Particularity of Liberal Democracy'. In Prospects for Democracy, edited by David Held. Cambridge: Polity, 1993.

Paris, Roland. 'Peacebuilding and the Limits of Liberal Internationalism'. International Security 22, no. 2 (1997): 54-89.

Partidge, William L., Jorge E. Uquillas, and Kathryn Johns. Including the Excluded: Ethnodevelopment in Latin America 1996 [cited 6 August 2001]. Available from htttp://wbln0018.worldbank.org/essd/essd.nsf/....

Pásara, Luis. 'The Guatemalan Peace Process: The Accords and Their Accomplishments'. In Kroc Institute Occasional Paper \#21: OP:3, 33. South Bend, 2001.

Paschall, Rod. 'Privatizing Counterinsurgency'. Terra Nova 2, no. 1 (1992): 31-41.

Pastor, Jr., Manuel, and Michael E. Conroy. 'Distributional Implications of Macroeconomic Policy: Theory and Application to El Salvador'. In Economic Policy for Building Peace: The Lessons of El Salvador, edited by James K. Boyce. Boulder: Lynne Rienner, 1996.

Patomaki, Heikki. 'The Challenge of Critical Theories: Peace Research at the Start of the New Century'. Journal of Peace Research 38, no. 6 (2001): 723-37.

Pearce, Frank, and Steve Tombs. 'Foucault, Governmentality, Marxism'. Social and Legal Studies 7, no. 4 (1998): 567-75.

Pearce, Jenny. 'From Civil War to 'Civil Society': Has the End of the Cold War Brought Peace to Central America?’ International Affairs 74, no. 3 (1998): 587-615.

- 'Peace-building in the Periphery: Lessons from Central America'. Third World Quarterly 20, no. 1 (1999): 51-68.

Pels, Peter. 'The Anthropology of Colonialism: Culture, History and the Emergence of Western Governmentality'. Annual Review of Anthropology 26 (1997): 163-83.

Pérez, Jacinto Carreto. 'Proceso de Paz y Población Maya'. América Indígena 57, no. 1-2 (1997): 39-62.

Pérez Sáinz, Juan Pablo. De la Finca a la Maquila. San José, Costa Rica: FLACSO, 1996.

Petras, James. 'Alternatives to Neoliberalism in Latin America'. Latin American Perspectives 24, no. 1 (1997): 80-91.

Petras, James F., and Morris H. Morley. 'Economic Expansion, Political Crisis and U.S. Foreign Policy in Central America'. In Revolution and Intervention in 
Central America, edited by Marlene Dixon and Susanne Jonas, 189-218. San Francisco: Synthesis Publications, 1983.

Phillips, Lynne. 'Introduction: Neoliberalism in Latin America'. In The Third Wave of Modernization in Latin America: Cultural Perspectives on Neoliberalism, edited by Lynne Phillips. Wilmington, DE: Scholarly Resources Inc., 1998.

Piccone, Paul. 'Gramsci's Hegelian Marxism'. Political Theory 2, no. 1 (1974): 32-45.

Plant, Roger. 'Ethnicity and the Guatemalan Peace Process: Conceptual and Practical Challenges'. In Guatemalan After the Peace Accords, edited by Rachel Sieder, 80-96. London: University of London Institute of Latin American Studies, 1998.

Polanyi, Karl. The Great Transformation. Boston: Beacon Press, 1957.

Porter, Michael E. 'The Competitive Advantage of Nations'. Harvard Business Review 65, no. 2 (1990): 73-93.

- The Competitive Advantage of Nations. New York: Free Press, 1990.

-. 'Competitiveness in Central America'. In Competitiveness in Central America: Preparing Companies for Globalization, edited by INCAE. San Jose, Costa Rica: Latin American Center for Competitiveness and Sustainable Development, 1996.

Preti, Alessandro. 'Guatemala, Violence in Peacetime: A Critical Analysis of the Armed Conflict and the Peace Process'. Disasters 26, no. 2 (2002): 99-119.

Pritchard, Diana. 'Refugee Repatriation and Reintegration'. In Central America: Fragile Transition, edited by Rachel Sieder, 103-36. London: Macmillan, 1996.

Quest Economics Database: Americas Review World of Information. Guatemala: Key Inidcators Janet Matthews Information Services, 2001 [cited 1 July 2002]. Available from Lexis-Nexis.

Rabe, Stephen G. The Most Dangerous Area in the World: John F. Kennedy Confronts Communist Revolution in Latin America. Chapel Hill: University of North Carolina, 1999.

Razeto Migliaro, Luis, and Pasquale Misuraca. 'The Theory of Modern Bureaucracy'. In Approaches to Gramsci, edited by Anne Showstack Sassoon, 70-91. London: Writers and Readers, 1982.

Reid, Herbert, and Ernest J. Yanarella. 'Toward a Critical Theory of Peace Research in the United States: The Search for an 'Intelligible Core". Journal of Peace Research 13, no. 4 (1976): 315-41.

Rich, Paul B., and Richard Stubbs. 'Introduction: The Counter-Insurgent State'. In The Counter-Insurgent State: Guerrilla Warfare and State Building in the Twentieth Century, edited by Paul B. Rich and Richard Stubbs, 1-25. London: Macmillan, 1997. 
Robinson, William I. 'Neoliberalism, the Global Elite, and the Guatemalan Transition: A. Critical Macrosocial Analysis'. Journal of Interamerican Studies and World Affairs 42, no. 2 (2000): 89-107.

Robinson, William I. 'Globalisation, the World System, and "Democracy Promotion" in U.S. Foreign Policy'. Theory and Society 25, no. 5 (1996): 615-65.

. 'Globalization, the World System, and "Democracy Promotion" in U. S. Foreign Policy'. Theory and Society 25, no. 5 (1996): 615-55.

. ' (Mal)Development in Central A merica: G lobalizarion and Social Change'. Development and Change 29 (1998): 467-97.

- Promoting Polyarchy: Globalization, US Intervention, and Hegemony. Vol. 48, Cambridge Studies in International Relations. Cambridge: Cambridge University Press, 1996.

Rojas, Paz. 'Impunity and the Inner History of Life'. Social Justice 26, no. 4 (1999): 13-29.

Rose, Nikolas. 'Governing "Advanced" Liberal Democracies'. In Foucault and Political Reason: Liberalism, neo-liberalism and rationalities of government, edited by Andrew Barry, Thomas Osborne and Nikolas Rose, 37-64. London: UCL Press, 1996.

Rose, Susan D., and Steve Brouwer. 'The Export of Fundamentalist Americanism: US Evangelical Education in Guatemala'. Latin American Perspectives 17, no. 4 (1990): 42-56.

Rosenthal, Gert. 'The Peace Process in Guatemala and the Role of Third Parties'. International Journal on Minority and Group Rights 8 (2001): 55-59.

Rostow, W.W. The Stages of Economic Growth: A Non-Communist Manifesto. 3rd ed. Cambridge: Cambridge University Press, 1990.

Ruggie, John Gerard. 'International Regimes, Transactions, and Change: Embedded Liberalism in the Postwar Economic Order'. International Organization 36, no. 2 (1982): 379-415.

Rupert, Mark. 'Alienation, Capitalism and the Inter-State System: Toward a Marxian/Gramscian Critique'. In Gramsci, Historical Materialism and International Relations, edited by Stephen Gill, 67-92. Cambridge: Cambridge University Press, 1993.

Russell, Andrew. 'Reviving Civil Society in Guatemala: Learning from UNDP's Experience'. Civil Soceity Organizations and Participation Programme, 1999.

Salvatore, Ricardo D. 'The Strength of Markets in Latin America's Sociopolitical Discourse, 1750-1850: Some Preliminary Observations'. Latin American Perspectives 26, no. 1 (1999): 22-43.

Salvesen, Hilde. 'Guatemala: Five years After the Peace Accords, The Challenges of Implementing Peace'. Oslo: Peace Research Institute, Oslo, 2002.

Santiso, Carlos. 'Promoting Democratic Governance and Preventing the Recurrence of Conflict: The Role of the United Nations Development Programme in Post- 
Conflict Peace-Building'. Journal of Latin American Studies 34, no. 3 (2002): 555-86.

Sassoon, Anne Showstack, ed. Approaches to Gramsci. London: Writers and Readers, 1982.

Gramsci and Contemporary Politics: Beyond Pessimism of the Intellect. Vol. 4, Routledge Innovations in Political Theory. London: Routledge, 2000.

Gramsci's Politics. Minneapolis: University of Minnesota Press, 1987.

Sauvage, Léo. Ché Guevara: The Failure of a Revolutionary. Translated by Raoul Frémont. Englewood Cliffs, NJ: Prentice-Hall, 1973.

Schirmer, Jennifer G. The Guatemalan Military Project: A Violence Called Democracy. Philadelphia: University of Pennsylvania Press, 1998.

Schlesinger, Stephen, and Stephen Kinzer. Bitter Fruit: The Untold Story of the American Coup in Guatemala. New York: Anchor Books, 1983.

Schroyer, Trent. 'Karl Polanyi's Post-Marxist Critical Theory'. In The Legacy of Karl Polanyi, edited by Marguerite Mendell and Daniel Salée, 66-85. Basingstoke: Macmillan, 1991.

Schulting, Gerard. 'ILO Convetion 169: Can it Help?' Abya Yala News 10, no. 4 (1997).

Scott, David. 'Colonial Governmentality’. Social Text 43 (1995): 191-220.

Scott, James C. Weapons of the Weak: Everyday Forms of Peasant Resistance. New Haven: Yale University Press, 1985.

Serafino, Nina M. 'Dateline Managua: Defining Democracy'. Foreign Policy 69 (1987): 166-82.

Shafer, D. Michael. Deadly Paradigms: The Failure of US Counterinsurgency Policy. Princeton: Princeton University Press, 1988.

Sharckman, Howard. 'The Vietnamization of Guatemala: US Counterinsurgency Programs'. In Guatemala, edited by Susanne Jonas and David Tobis, 193-203. Berkeley, CA: North American Congress on Latin America, 1974.

Shaw, Karena. 'Indigeneity and the International'. Millennium: Journal of International Studies 31, no. 1 (2002): 55-81.

Shaw, Timothy M. 'Beyond Post-Conflict Peacebuilding: What Links to Sustainable Development and Human Security'. International Peacekeeping 3, no. 2 (1996): 36-50.

Shultz Jr., Richard H., Robert. L. Pfaltzgraff Jr., William J. Olson, and I gor Lukes. Guerrilla Warfare and Counterinsurgency: US -Soviet Policy in the Third World. Lexington, MA: Lexington Books, 1989.

Sieder, Rachel. 'Conclusions'. In Guatemalan After the Peace Accords, edited by Rachel Sieder, 245-54. London: University of London Institute of Latin American Studies, 1998. 
- 'Reframing Citizenship: Indigenous Rights, Local Power and the Peace Process'. In Negotiating Rights: the Guatemalan Peace Process, edited by Jeremy Armon, Rachel Sieder and Richard Wilson, 66-73. London: Conciliation Resources, 1997.

Sieder, Rachel, and Patrick Costello. 'Judicial Reform in Central America: Prospects for the Rule of Law'. In Central America: Fragile Transition, 1996.

Simon, Roger. Gramsci's Political Thought. London: Lawrence \& Wishart, 1991.

Smart, Barry. Foucault, Marxism and Critique. London: Routledge \& Kegan Paul, 1983.

Smith, Anna Marie. Laclau and Mouffe: The Radical Democratic Imaginary. London: Routledge, 1998.

Smith, Anthony D. 'Conflict and Collective Identity: Class, Ethnie and Nation'. In International conflict resolution: theory and practice, e dited b y Jo hn $\mathrm{B}$ urton and Edward Azar, 63-84. Brighton: Wheatsheaf Books Ltd., 1986.

- 'Culture, Community and Territory: The Politics of Ethnicity and Nationalism'. International Affairs 72, no. 3 (1996): 445-58.

Smith, Carol A. 'Conclusion: History and Revolution in Guatemala'. In Guatemalan Indians and the State, 1540 to 1988, edited by Carol A. Smith, 258-86. Austin: University of Texas Press, 1990.

, ed. Guatemalan Indians and the State, 1540 to 1988. Austin: University of Texas Press, 1990.

'Introduction: Social Relations in Guatemala over Time and Space'. In Guatemalan Indians and the State, 1540 to 1988, edited by Carol A. Smith, 134. Austin: University of Texas Press, 1990.

. 'Local History in Global Context: Social and Economic Transitions in Western Guatemala'. Comparative Studies in Soceity and History 26, no. 20 (1984): 193-228.

. 'The Militarization of Civil Society in Guatmela: Economic Reorganization as a Continuation of War'. Latin American Perspectives 17, no. 4 (1990): 8-41.

. 'Origins of the National Question in Guatemala: A Hypothesis'. In Guatemalan Indians and the State, 1540 to 1988, edited by Carol A. Smith, 7295. Austin: University of Texas Press, 1990.

- 'Race-Class-Gender Ideology in Guatemala: Modern and Anti-Modern Forms'. Comparative Studies in Society and History 37, no. 4 (1995): 723-49.

Soederberg, Susanne. 'On the contradictions of the New International Financial Architecture: A nother P rocrustean Bed for E merging Markets?' Third World Quarterly 23, no. 4 (2002): 607-20.

Sollis, Peter. 'Partners in Development? The State, Nongovernmental Organisations and the UN in Central America'. Third World Quarterly 16, no. 3 (1995): 52642 . 
Steele, Johnathan. 'Europeans Back Arias Peace Plan for Central America'. The Guardian, 22 May 1987.

Stepputat, Finn. 'Politics of Displacement in Guatemala'. Journal of Historical Sociology 12, no. 1 (1999): 54-80.

Stoll, David. Between Two Armies in the Ixil Towns of Guatemala. New York: Columbia University Press, 1993.

. 'Human Rights, Land Conflict and Memories of the Violence in the Ixil Country of Northern Quiché'. In Guatemalan After the Peace Accords, edited by Rachel Sieder, 42-56. London: University of London Institute of Latin American Studies, 1998.

. Is Latin America Turning Protestant? The Politics of Evangelical Growth. Berkeley: University of California Press, 1990.

Stubbs, Richard. Hearts and Minds in Guerrilla Warfare: The Malayan Emergency 1948-1960. Singapore: Oxford University Press, 1989.

Szakolczai, Arpád. 'From Governmentality to the Genealogy of Subjectivity: On Foucault's Path in the 1980s'. Florence: European Univeristy Institute, 1993.

Tanzi, Alex. IMF's Annual GDP Percent Change Forcasts 2001 [cited 1 July 2002]. Available from Lexis-Nexis.

Taussig, Michael. Shamanism, Colonialism and the Wild Man: A Study in Terror and Healing. Chicago: Chicago University Press, 1987.

Texier, Jacques. 'Gramsci, Theoretician of the Superstructures'. In Gramsci and Marxist Theory, edited by Chantal Mouffe, 48-79. London: Routledge and Kegan Paul Ltd., 1979.

Tobis, David. 'The US Investment Bubble in Guatemala'. In Guatemala, edited by Susanne Jonas and David Tobis, 132-42. Berkeley, CA: North American Congress on Latin America, 1974.

Topik, Steven. 'The Construction of Market Society in Latin America: Natural Process or Social Engineering?' Latin American Perspectives 26, no. 1 (1999): 3-21.

Torres-Rivas, Edelberto. 'Central America'. In Cambridge History of Latin America, edited by Leslie Bethell, 687-90. Cambridge: Cambridge University Press, 1995.

History and Society in Central America. Translated by Douglass SullivanGonzález. Austin: University of Texas Press, 1993.

Negociando el Futuro: La Paz en una Sociedad Violenta. Vol. 36, Debate. Guatemala: FLACSO, 1997.

Trudeau, Robert H. Guatemalan Politics: The Popular Struggle for Democracy. Boulder: Lynne Rienner, 1993.

Tully, James. Strange Multiplicity: Constitutionalism in an Age of Diversity, the John Robert Seeley lectures. Cambridge: Cambridge University Press, 1995. 
Tuyuc, Rosalina. 'Los Acuerdos de Paz, los Pueblos Indígenas y la Reforma Política'. In Guatemalan After the Peace Accords, edited by Rachel Sieder, 238-42. London: University of London Institute of Latin American Studies, 1998.

Tuyuc Velásquez, Rosalina. 'Tendencias Legislativas sobre Derecho Indígena en Guatemala'. América Indígena 57, no. 1-2 (1997): 35-38.

Urban, Greg, and Joel Sherzer. 'Introduction: Indians, Naton-States, and Culture'. In Nations-states and Indians in Latin America, edited by Greg Urban and Joel Sherzer, 1-18. Austin: Univeristy of Texas Press, 1991.

Urbinati, Nadia. 'From the Periphery of Modernity: Antonio Gramsci's Theory of Subordination and Hegemony'. Political Theory 26, no. 3 (1998): 370-91.

URNG. 'Balance del Processo de Paz 1997-1999'. 36. Guatemala: URNG, 1999.

- 'Cumplimiento de los Acuerdos de Paz: Abril -Diciembre 1997'. 47. Guatemala: URNG, 1998.

—. 'Una Paz Justa y Democrática: Contenido de la Negociación'. May. Guatemala, 1992.

USAID. 'Guatemala'. Washington, DC: USAID, 1996.

Valenzuela, J. Samuel, and Arturo Valenzuela. 'Modernization and Dependency'. Comparative Politics (1978): 535-57.

van der Pij1, Kees. 'Soviet Socialism and Passive Revolution'. In Gramsci, Historical Materialism and International Relations, edited by Stephen Gill, 237-58. Cambridge: Cambridge University Press, 1993.

Vincent, R. J. 'Race in International Relations'. International Affairs 58, no. 4 (1982): 658-70.

Vitalis, Robert. 'The Graceful and Generous Liberal Gesture: Making Racism Invisible in American International Relations'. Millennium 29, no. 2 (2000): 331-56.

Walker, R.B.J., ed. Culture, Ideology, and World Order. Boulder, CO: Westview Press, 1984.

Wallerstein, Immanuel. 'La Construction des Peuples: Racisme, Nationalisme, Ethnicité'. In Race, Nation, Classe: Les Identités Ambiguës, edited by Etienne Balibar and Immanuel Wallerstein, 95-117. Paris: Éditions la Découverte, 1988.

- 'Universalisme, Racisme, Sexisme: Les Tensions Idéologiques du Capitalisme'. In Race, Nation, Classe: Les Identités Ambiguës, edited by Etienne Balibar and Immanuel Wallerstein, 42-53. Paris: Éditions la Découverte, 1988.

Warren, Kay B. Indigenous Movements and Their Critics: Pan-Mayan Activism in Guatemala. Princeton, NJ: Princeton University Press, 1998.

Watkins, Evan. 'Gramscian Politics and Capitalist Common Sense'. Rethinking Marxism 11, no. 3 (1999): 83-90. 
Watson, Sean. 'Policing the Affective Society: Beyond Governmentality in the Theory of Social Control'. Social and Legal Studies 8, no. 2 (1999): 227-51.

Weaver, Frederick Stirton. 'Reform and (Counter)Revolution in Post-Independence Guatemala: Liberalism, Conservatism and Postmodern Controversies'. Latin American Perspectives 26, no. 105 (1999): 129-58.

Weeks, John. The Economies of Central America. New York: Holmes and Meier, 1985.

Whitehead, Laurence. 'Pacification and Reconstruction in Central America: The International Components'. In Central America: Fragile Transition, edited by Rachel Sieder, 215-46. London: Macmillan, 1996.

Whitfield, Teresa. 'The Role of the United Nations in El Salvador and Guatemala: A Preliminary Comparison'. In Comparative Peace Processes in Latin America, edited by Cynthia Arnson, 257-90. Stanford: Stanford University Press, 1999.

Williams, David. 'Constructing the Economic Space: The World Bank and the Making of Homo Oeconomicus'. Millennium: Journal of International Studies 28, no. 1 (1998).

Williams, Gwyn A. Proletarian Order: Antonio Gramsci, Factory Councils and the Origins of Italian Communism 1911-1921. London: Pluto Press, 1975.

Williams, Robert G. States and Social Evolution: Coffee and the Rise of National Governments in Central America. Chapel Hill: University of North Carolina Press, 1994.

Williford, Miriam. Jeremy Bentham and Spanish America. Baton Rouge: Louisiana State University Press, 1980.

Wilmer, Franke. The Indigenous Voice in World Politics. Edited by Francis A. Beer and Ted Robert Gurr, Violence, Cooperation, Peace: Sage, 1993.

Wilson, Richard. 'Violent Truths: the Politics of Memory in Guatemala'. In Negotiating Rights: the Guatemalan Peace Process, edited by Jeremy Armon, Rachel Sieder and Richard Wilson, 18-27. London: Conciliation Resources, 1997.

Woodward Jr., Ralph Lee. Central America: A Nation Divided. 3rd ed. New York: Oxford University Press, 1999.

. 'Changes in the Nineteenth -Century Guatemalan State and Its Indian Policies'. In Guatemalan Indians and the State, 1540 to 1988, edited by Carol A. Smith, 52-71. Austin: University of Texas Press, 1990.

- ' 'The Rise and Decline of Liberalism in Central America: Historical Perspectives on the Contemporary Crisis'. Journal of Interamerican Studies and World Affairs 26, no. 3 (1984): 291-312.

Woolcock, Joseph A. 'Politics, Ideology and Hegemony in Gramsci's Theory'. Social and Economic Studies 34, no. 3 (1985): 199-210. 
Woolcock, Michael. 'Social Capital and Economic Development: Toward a Theoretical Synthesis and Policy Framework'. Theory and Society 27, no. 2 (1998): 151-208.

World Bank. 'Economic Analysis of Rural Land Administration Projects'. Washington, dc: World Bank.

. 'El Salvador: Meeting the Challenge of Globalization'. Washington, DC: World Bank, 1995.

- 'Framework for Macroeconomic Stability: the Challenges Ahead'.

. 'Guatemala: Building Peace with Rapid and Equitable Growth'. 40. Washington, DC: World Bank, 1996.

. 'Guatemala: Expenditure Reform in a Post-Conflict Country'. Washington, DC: World Bank, 2000.

'Guatemala: Investing for Peace: A Public Investment Review'. Washington, DC: World Bank, 1997.

. 'OP2.30 'Development Cooperation and Conflict' A New Operational Policy for the Bank'. Washington, DC: World Bank.

- 'Post-Conflict Reconstruction: The Role of the World Bank'. 69. Washington, DC: World Bank, 1998.

. The Theory Behind Market-Assisted Land Reform [cited 19 July 2001]. Available from http://wbln0018.worldbank.org/networks.essd.icdb.nsf/...

- The Transition from War to Peace: An Overview World Bank, [cited 5 July 2001]. Available from http://wbln0018.worldbank.org/...

Yashar, Deborah. 'The Quetzal is Red: Military States, Popular Movements, and Political V iolence in Guatemala'. In The New Politics of Inequality in Latin America, edited by Douglas Chalmers et. al., 239-60. Oxford: Oxford University Press, 1997.

Yashar, Deborah J. 'Democracy, Indigenous Movements and the Postliberal Challenge in Latin America'. World Politics 52, no. 1 (1999): 76-104.

Zur, Judith. 'The Psychological Effects of Impunity: The Language of Denial'. In Impunity in Latin America, edited by Rachel Sieder, 57-72. London: University of London, Institute of Latin American Studies, 1995.

'The Psychological Impact of Impunity'. Anthropology Today 10, no. 3 (1994): 12-17. 